\title{
A revision of the genus Swainsona (Fabaceae)
}

\author{
Joy Thompson
}

\begin{abstract}
Thompson, Joy (National Herbarium of New South Wales, Royal Botanic Gardens, Sydney, NSW, Australia 2000) 1993. A revision of the genus Swainsona (Fabaceae). Telopea 5(3): 427-581. The genus Swainsona is revised. A key to the 85 species precedes a formal treatment of these taxa, of which sixteen are new (Swainsona calcicola, S. complanata, S. cornuta, S. disjuncta, S. eremaea, S. fuscoviridis, S. halophila, S. longicarinata, S. longipilosa, S. paucifoliolata, S. perlonga, S. rostrata, S. rotunda, S. sejuncta, S. tanamiensis, S. vestita) and two of altered rank (S. acuticarinata (A. Lee) J. Thompson, S. elegantoides (A. Lee) J. Thompson). The species are placed in groups according to perceived relationship and keys provided to groups and to species within each group. The genus is restricted to Australia except for one endemic New Zealand species.
\end{abstract}

\section{Introduction}

This work was undertaken as a precursor to a treatment of the genus for the 'Flora of Australia'. A.T. Lee (1948) published a revision of the genus that was sound and perceptive. She had little access to herbaria other than NSW, apart from a visit to MEL, but received co-operation from other workers such as J.M. Black (AD) and C.A. Gardner (PERTH) so that she was able to treat the genus on an Australia-wide basis. Her erudition and their examination of critical specimens at $\mathrm{K}$ facilitated her accurate use of nomenclature that still stands for most species. Unfortunately at the time Lee was working there had been little botanical exploration of those parts of central and western Australia soon to be opened up as vehicular routes and for mining exploration and development. The collections built up since that time have included many new species and have shown some of Lee's taxa to need redefinition.

Our lack of information about important aspects of the biology of Swainsona should not invalidate speculation about the position of this genus in the Fabaceae. There can be no doubt that it is closely related to genera placed in the tribe Galegeae by Polhill \& Raven (1981). It is most unfortunate that Polhill did not refer to Lee's (1948) publication and apparently assumed Swainsona to be well represented by the relatively unmodified S. galegifolia. As a result of this assumption his keys to the subtribes, and the genera within them, are nullified by different species of Swainsona that run down in almost all key-leads.

The relationships of genera within this tribe are not well understood. Over the years species have been moved from genus to genus, and genera split and reunited. Barneby (1964) gave the history of the development of understanding of Astragalus (to quote Bentham (1866), 'a very numerous genus') and Oxytropis ('a considerable genus'), and it seems more than coincidental that the majority of character-states used by Sanderson (1991) in his cladistic analysis of 113 taxa of North American Astragalus would be those chosen for a similar work on Swainsona to reflect apomorphies found in Australasia. The parallels between evolutionary changes within this well known group of taxa and those that have occurred in Swainsona are striking and Sanderson (1991), in phylogenetic studies in Astragalus, also discussed problems of relationship. It is unfortunate that so many genera of the Galegeae are still little known, and obvious that 
they are now delimited by convention rather than by sound taxonomy. Lee suggested that 'Swainsona is one of a group of Leguminosae whose separation is more arbitrary than most', and Barneby that 'the question of generic limits in the Galegeae is fraught with difficulty'. I am accepting Swainsona as a distinct genus, as circumscribed here, on the basis of its geographic isolation from those genera on other continents that appear to be closely related to it. I do not consider it to be more closely related to African genera than to those of North America. Swainsona's uniform chromosome number of $2 n=32$ is not common in other genera of the tribe where $2 n=16$ is common and often uniform. Clianthus and the genera separated in Polhill \& Raven (1981) as the tribe Carmichaelieae have a uniform number of 32, and it is perhaps here that Swainsona's closest relatives are to be found. Much remains to be done before the taxonomic structure of this part of the Fabaceae is well understood and, within Swainsona, much to be elucidated; but now that those previously little-known areas inhabited by many species of Swainsona have become more accessible, observation will become a less daunting task.

Swainsona is well known as a cause of stock-poisoning, the poisonous principle, swainsonine, affecting the nervous system. Swainsonine is also found in the genus Astragalus (Fellows 1989). It is not always known, owing to past widespread misidentification and contradictory specimen notes, which species are involved.

A few species of Swainsona have been cultivated in gardens of Europe, often by grafting onto a Colutea stock, but they are rarely seen in horticulture now, in spite of their beauty, perhaps owing to their failure to persist.

It can be readily observed that many, perhaps most, species are erratic in their occurrence, carpeting the landscape after significant rain in areas of low and irregular rainfall. A few are recorded as being found after fire, even after many decades of apparent absence.

\section{Diagnostic Characters}

In generic and specific descriptions I have tried to cover much of the variation to be found in this genus, but for many features this has not been feasible. Like many taxa that can successfully invade inhospitable areas, Swainsona may live its life in a short time while conditions are favourable or may persist to become much larger in its vegetative parts, and more floriferous, when conditions allow. It is impossible and useless to cover all variation in dimensions in these cases and in the case of many species this is as yet unknown, each new collection altering perception of the norm.

The treatment presented here has suffered from many of the problems that beset Lee, because Swainsona is a genus with features of significance that are difficult to assess in the herbarium. Where possible I have followed the terminology used by Lee but the larger range of specimens available now has shown additional useful features, and that some character-states are more variable and therefore less useful than was previously supposed. As the base of the plant is rarely collected, it is difficult to ascertain whether one or several stems arise there, where the stem-bases are in relation to soil-level, or even whether the plant is annual or perennial, in many cases. Barneby (1964) describes the roots and stem-bases of Astragalus and regards differences as phylogenetically significant, as does Sanderson (1991). Such observations on Swainsona are too few to allow accurate descriptions for a majority of species. For the stem descriptions I have had to rely on dried material and live plants will not show the same ridging. The stem hairs are usually characteristic for the species but are more variable than was assumed by Lee. Barneby's description of Astragalus vesture 
covers most of the variants found in Swainsona. The presence of medifixed hairs (said to be 'biramous' by Polhill \& Raven (1981) and 'dolabriform' by Barneby (1964)), is a very useful diagnostic character.

Leaf descriptions here cover most of the variation shown but do not attempt to cover the occasional extremes found in this variable genus. The petiole, i.e. the rhachis below the lowest leaflet, is variable in length but is considered short when it does not exceed the leaflet-length. The number, size and shape of leaflets varies with their position on the plant, and its vigour. There is also a range of apex-shapes, especially of indentation that can be covered only by generalisation. The terminal leaflet often varies in its size in relation to the lateral leaflets but in many species is usually conspicuously larger. It is sometimes irregular in its formation and may occur as an unequal-sized pair. Leaflets are often, but not invariably, undeveloped in some species under circumstances yet to be determined. Stipules (Fig. 1) may vary within the species but especially with their position on the plant. The most phylogenetically significant feature is the formation of an abaxial ridge by the bases of a pair of stipules. This condition, from comparison with closely related genera, is primitive in Swainsona but is certainly absent from the majority of species. In some it is present only at nodes near the base of the plant. The stipules usually vary in size, and when a few millimetres long are deltoid-acuminate and usually lacking teeth. Occasionally stipules become scarious only at the base of the plant. Descriptions have been drawn from those on the upper part of the plant to avoid including even more variation.

Racemes are also very variable, varying in flower number with the amount of development of the plant and, in cases where the flowers differ in age within the raceme, when those on the upper part are undeveloped as lower flowers are fading. It is not possible to give precise flower-counts and raceme-measurements. Descriptions of the peduncle striations have been taken from dried material.

A series of characters of major diagnostic significance, and probably indicative of important evolutionary steps, is found in the flower, with its various but variable petal-shapes, petal-twisting and style morphology, but many of these cannot be assessed with confidence from herbarium material. The hypanthium (Fig. 2) between the pedicel and the calyx is basically obconic and considered broad when about as wide as long. Its length is usually half or equal to the length of the calyx-tube. The associated bracteoles are usually insignificant, narrow-deltoid and approximately the length of the hypanthium. They vary in their point of attachment to it. The calyx (Fig. 2) carries a number of useful characters but variation makes some of these difficult to quantify. Further study of the relationship between sizes and shapes of the usually somewhat dissimilar lobes may be profitable. The upper two lobes are often broader and shorter than the lower and the lowest is sometimes extended a little. The sinuses between the lobes vary in shape but within a range that is often characteristic of the species. The standard varies in shape within a species, especially as to definition of the claw. Although difficult to describe, the shape and length to breadth proportion is useful in defining and relating species. Of considerable significance is the surface sculpture at the base of the standard (Fig. 3). This is difficult to ascertain in dried material, varying as it does from the large boss of $S$. formosa to a conspicuous indentation in other species. Associated with this is the presence or absence of basal calli, that may be so broad as to cover much of the petal width above the claw or small and discrete, and other modifications of and thickenings near the petal base. These features appear to be valuable in assessing relationships between species, and study of living material should be rewarding. The wings (Fig. 4) are often of characteristic shape, and diagnostic for the species, but in most species are variably modified oblong with their axes somewhat curved. The basal claw usually occupies approximately $1 / 3$ of the total length; it may be narrow, i.e. almost parallel-sided, or may taper 

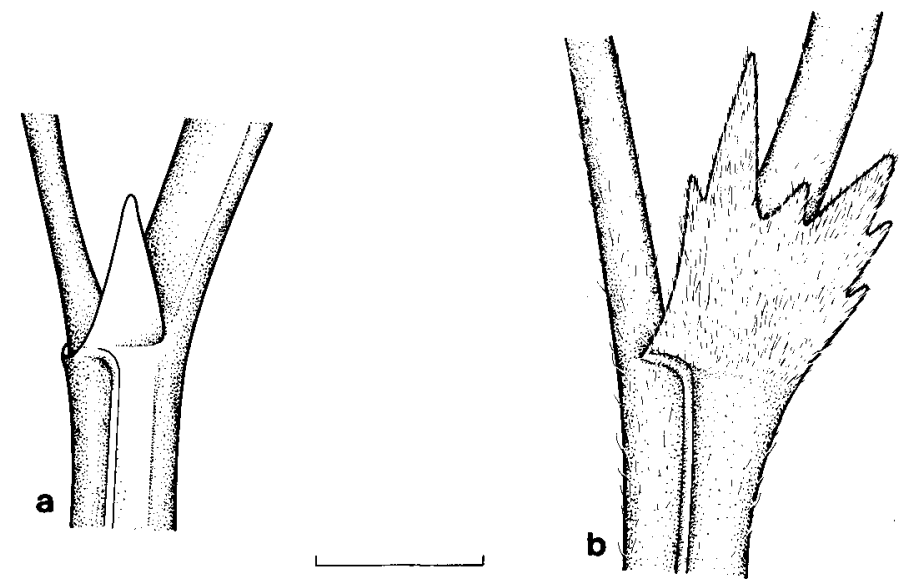

Figure 1. Stipules. a, S. galegifolia; b, S. beasleyana. (Scale bar $=5 \mathrm{~mm})$.
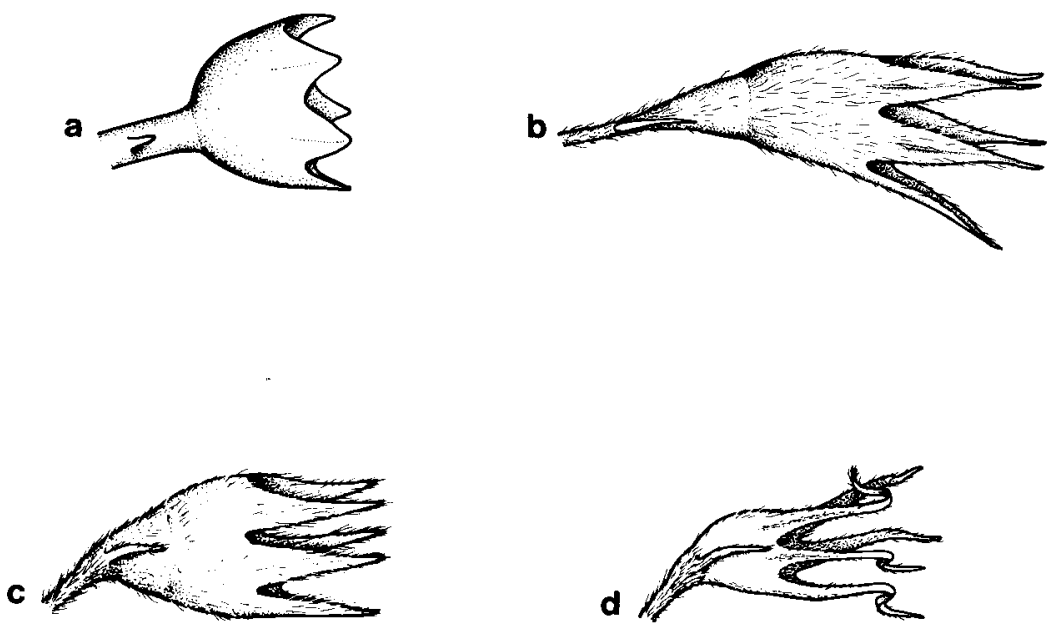

Figure 2. Hypanthium and calyx. a, S. galegifolia; b, S. beasleyana; c, S. phacoides; d, S. oligophylla. (Scale bar $=5 \mathrm{~mm}$ ). 

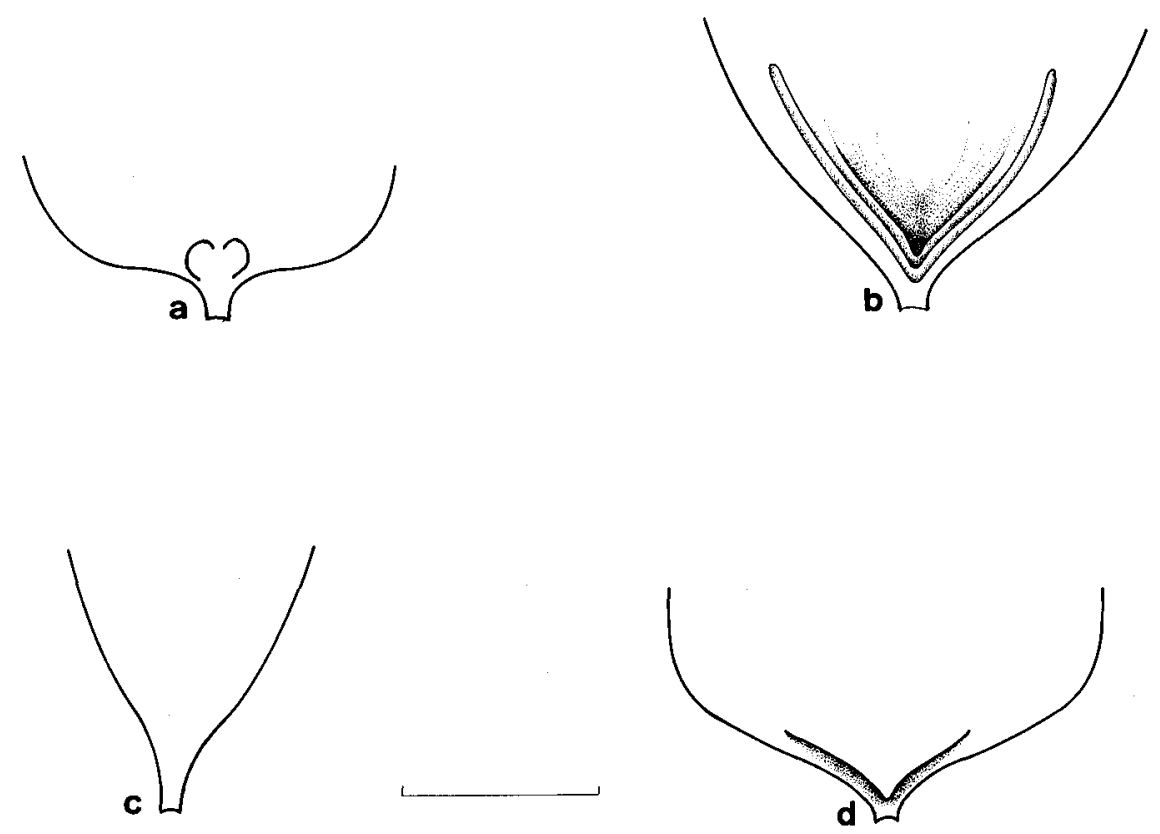

Figure 3. Base of standard. a, S. galegifolia; b, S. maccullochiana; c, S. luteola; S. swainsonioides. (Scale bar $=5 \mathrm{~mm}$ ).

a
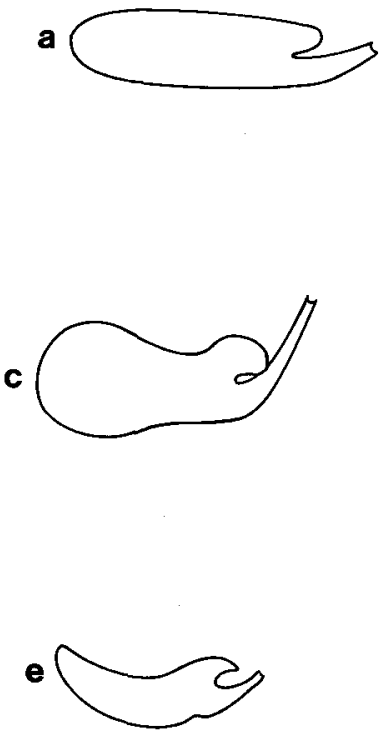

b

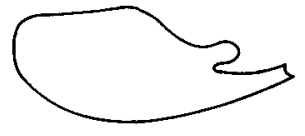

d
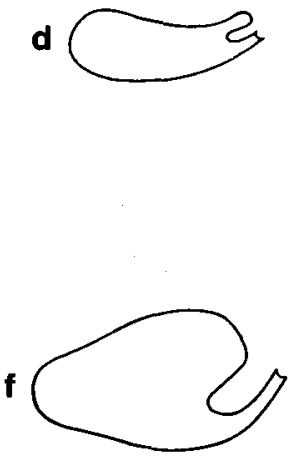

Figure 4. Wing. a, S. colutoides; b, S. ecallosa; c, S. recta; d, S. flavicarinata; e, S. burkittii; f, $S$. plagiotropis (Scale bar $=5 \mathrm{~mm}$ ). 
strongly, and its curvature may vary from slight to strong. Above the claw the upper margin of the wing is variously extended to form an auricle. The auricle is often distinct and erect (deep) but more frequently extends parallel to the claw, usually covering $1 / 2$ to $1 / 3$ the claw-length but often shorter and occasionally longer. The apex of the auricle is broadly to narrowly rounded. The apex of the wing is usually broadly rounded, sometimes after tapering, sometimes after an expansion. Occasionally it is narrow enough to be considered acute, sometimes broad enough to be almost truncate. It is often oblique so that, allowing for curvature, the petal is longest at either the upper or lower part of its apex. The keel (Fig. 5) carries many diagnostic characters. Its claw is usually approximately $1 / 3$ of the total length but varies in many species. The auricles are even more variable than those of the wings, and occasionally absent. Below the auricles many species display distortions which would be better studied in living material. Some of these are found as distinct small pockets but others are indistinct folds or swellings more difficult to describe. The upper margins of the keel often have a downward or an upward curve behind the apex and the lower surface may be obscurely or obviously distinguished from the claw. The apex carries most significant features being often much modified. It is sometimes beak-like, often somewhat upwardly directed, sometimes retracted, sometimes extended, and occasionally it bears extensions either side of its tip. The twisting of the keel is not only difficult to observe in the herbarium but is not a matter only of degree; in some cases the twist appears to involve most of the keel but in others a turning of the apical portion to one side. It is possible that there are some species with distortions that have so far been overlooked.

The ovary and its associated stipe and style are not clearly distinguishable and consequently not easy to define and measure. The stipe is here assumed to be the area below the cavity of the ovary where there is a narrowing of the circumference but in some taxa this point is not easy to discern. The stipe is said here to be slender when much narrower than the ovary circumference, and stout when there is less discrepancy. The same problem applies to the point at which the ovary apex becomes the base of the style. In this area there is often a stiffening of the tissue and/or extension in one or other dimension while in some species the tissue remains soft and in dried material looks narrower than the style above. The interior of the ovary cavity has not been studied here. The style, with its variation in so many features is of great significance (Fig. 6). It is not difficult to observe but its variations are difficult to describe. Its length, to avoid confusion in relating it to the altering length of the extending ovary, is here included in the description of the fruit, to which it usually remains attached. The unmodified and primitive style is long, to $5 \mathrm{~mm}$ or more, and slender, less than $0.5 \mathrm{~mm}$ wide, and tapers very gradually to a fine tip, but most species have styles that are modified in various ways, especially as to stiffening that is found over part or the whole length rendering the surface pale and smooth. The style-tips show much more variation than the examples illustrated by Lee and I have found that there is some variability in the amount and disposition of the hairs behind the tip (the tuft) and the beard.

A major series of features is carried by the fruit (Fig. 7). Fruit characters so widely used in early botanical work in the Galegeae are frustratingly difficult to assess. Few species have been collected with enough fruiting material to enable confident judgement of maturity and the normal associated characteristics, but fruit in Swainsona is both phylogenetically and diagnostically of great significance. It would appear that the primitive and most unmodified fruit is much inflated, to about as wide as deep in the middle of the curved base and about twice as long as deep. It has numerous ovules, erratic in their maturing into viable seed, found along an almost straight sutural side and its texture is rather stiffly membranous with a smooth surface with inconspicuous venation at right angles to the midvein on its lower margin. This fruit 

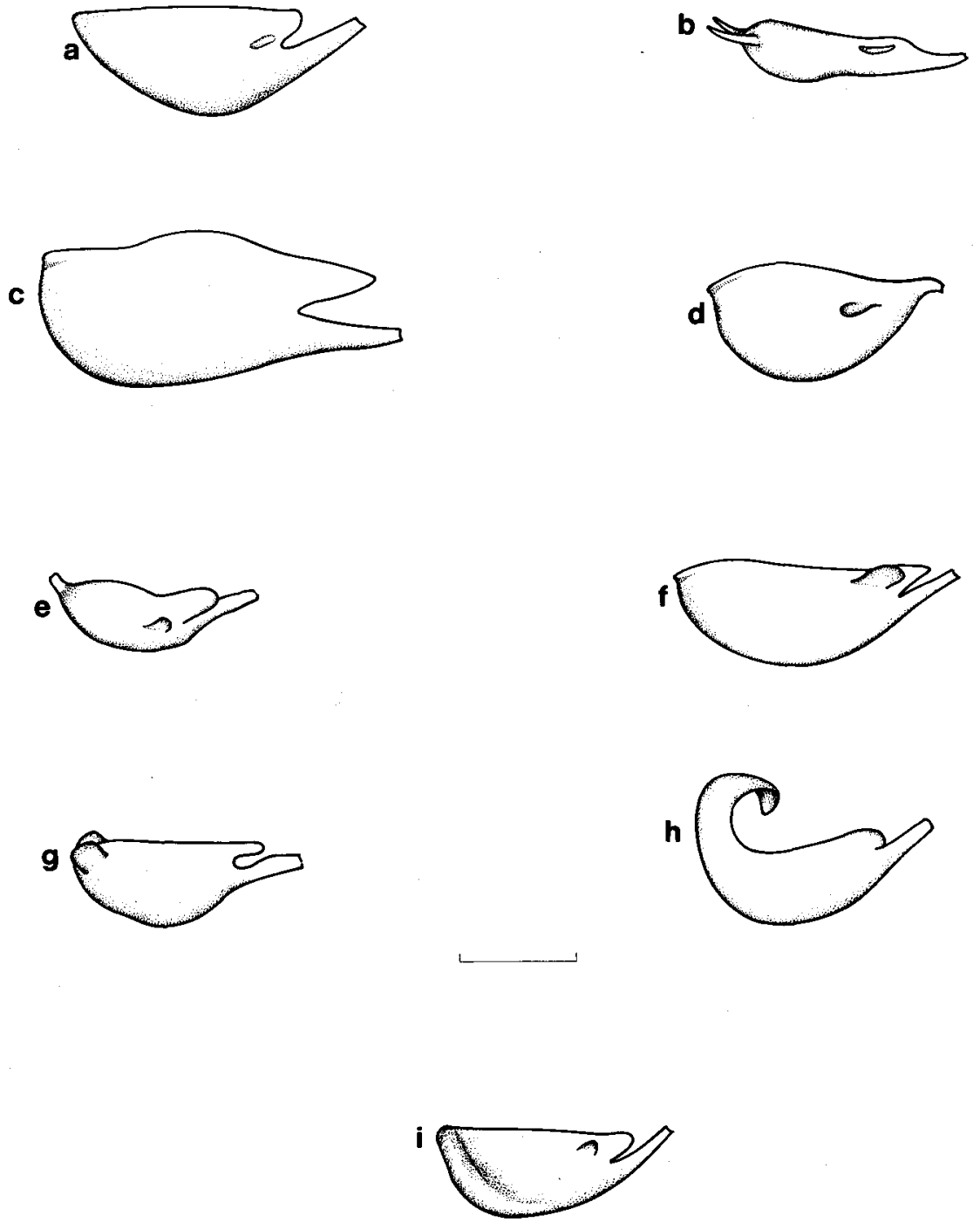

Figure 5. Keel. a, S. galegifolia; b, S. cornuta; c, S. calcicola; d, S. viridis; e, S. recta; f, S. phacoides; g, S. canescens; $\mathbf{h}, S$. swainsonioides; $\mathbf{i}, S$. fissimontana. (Scale bar $=5 \mathrm{~mm}$ ). 

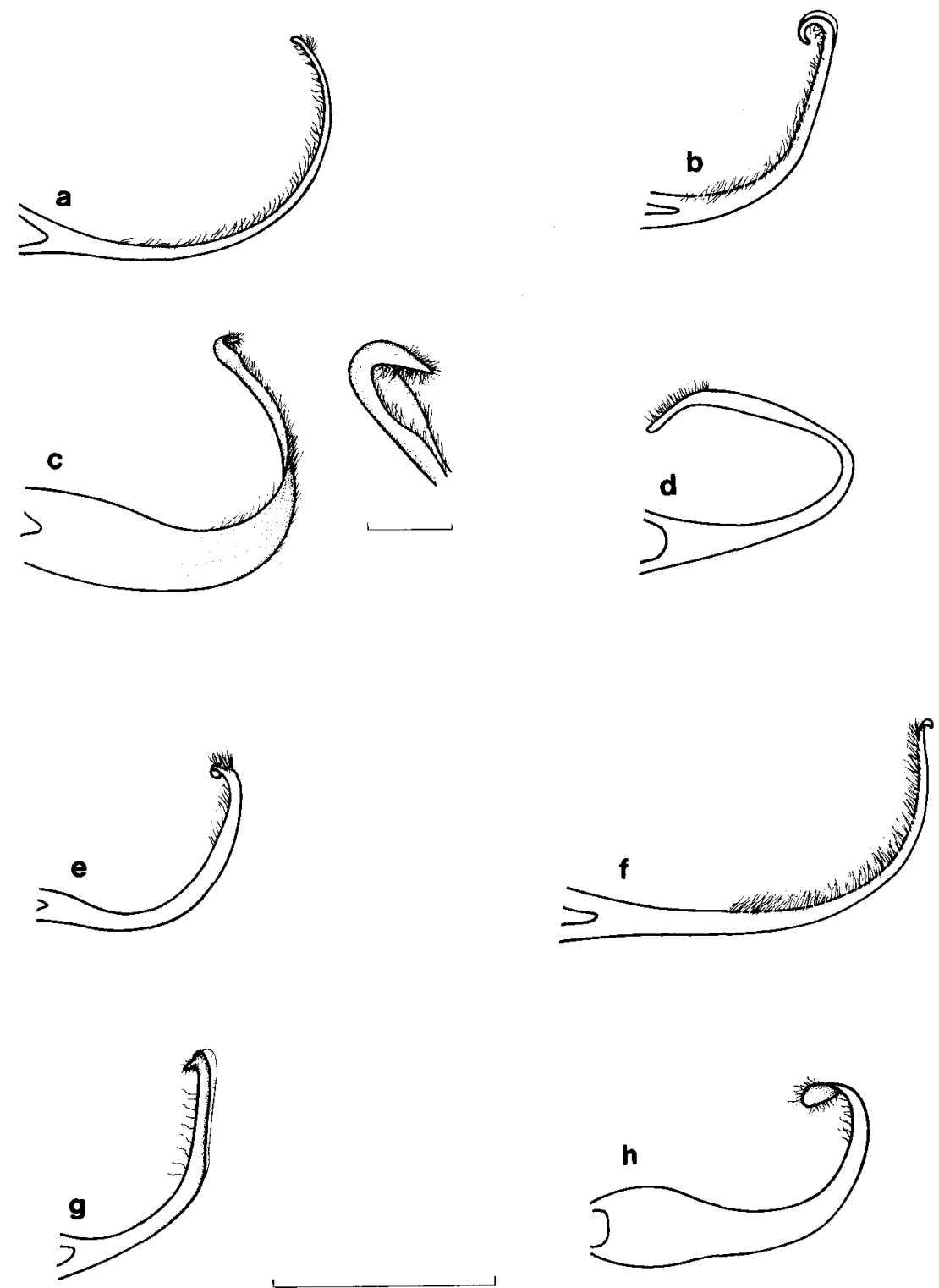

Figure 6. Style. a, S. colutoides; b, S. canescens; c, S. pterostylis; d, S. plagiotropis; e, S. paradoxa; f, S. purpurea; $\mathbf{g}$, S. reticulata; $\mathbf{h}$, S. murrayana. (Scale bar: enlargement of $\mathbf{c}=0.5 \mathrm{~mm}$; all others $=5 \mathrm{~mm}$ ). 

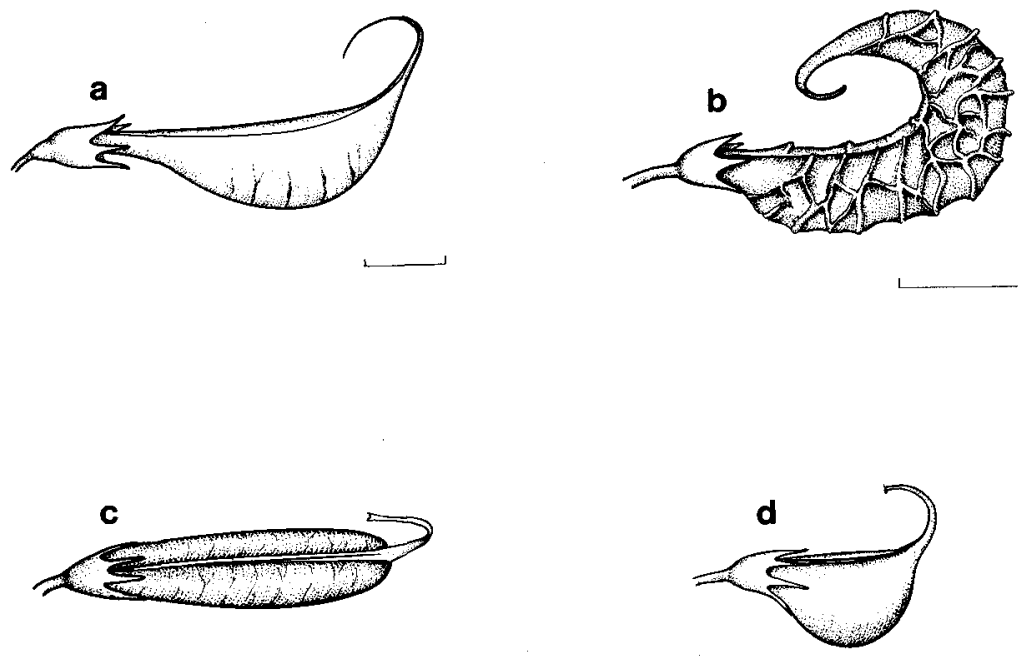

Figure 7. Fruit. a, S. colutoides; b, S. cyclocarpa; c, S. reticulata; d, S. affinis. (Scale bars $=10 \mathrm{~mm}$ ).

is conspicuously stipitate, persistent, and dehiscent at least along the upper, sutural, margin. Almost all species are modified to a greater or lesser extent from this. Variations include changes in shape, surface pattern, texture, which may also vary with maturity, dehiscence, which is difficult to assess in the herbarium, and inflation which also varies with circumstances not yet assessed. Many species have fruit inflated either side of a depressed or even a deeply indented suture. Some fruits are bilaterally flattened, some dorsiventrally so, and some change as they mature. Many species have a reduced ovule-number, while some have an amorphous pithy fruit-valve lining. In the majority of species a thin tissue in which the funicles are embedded intrudes into the loculus from the sutural side. This, and the funicles, may be short or so long as to seal the loculus so that the ovules are laterally displaced into what has become a bilocular fruit. Sometimes the intrusion of the sutural side allows even short funicular tissue to make the fruit bilocular. In some species the tissue is deep only in its central area so that the seal does not reach the apex and/or base of the locular chamber. Barneby (1964) discusses this phenomenon in Astragalus and refers to the tissue as a 'funicular flange' in order to distinguish it from the septum that in that genus may intrude from the opposite side of the fruit. Swainsona shows basal intrusion of the fruit surface very rarely and very slightly. Seeds have proved difficult to study, few being available in the mature state and those seen seeming to be somewhat inconsistent in size, shape, surface sculpturing and colour. 


\section{Swainsona}

Swainsona Salisb. (W. Hooker \& R.A. Salisbury 1806: t. 28); named after Isaac Swainson (1746-1812) who had a private botanic garden at Twickenham.

TYPE: S. coronillifolia Salisb. = S. galegifolia (Andr.) R. Br.

Cyclogyne Benth. (J. Lindley 1839: 16). TYPE: C. canescens Benth. (S. canescens (Benth.) F. Muell.)

Diplolobium F. Muell. (F. Mueller 1863: 489). TYPE: D. walcottii F. Muell. (S. pterostylis (DC.) Bakh.f.)

\section{Generic description}

Herbaceous, or scarcely woody, occasionally annual, mostly perennial and often ephemeral plants with numerous, few, or, rarely, single stems from a taproot or stout and complex stock, sometimes rhizomatous with stout or threadlike rhizomes; variable in habit, but usually broader than high, sometimes shrublike, often prostrate, occasionally erect, from a few centimetres to over 2 metres high but mostly less than 0.5 metres. Stems stout or slender, often branching near the base, frequently somewhat to obviously flexuose and usually, sometimes upwardly, extended below each node and with slight to strong, sometimes almost wing-like, longitudinal ridges below the nodes; occasionally glabrous, usually pubescent with terete or flattened, often turgid, spreading or appressed, basifixed, often asymmetrically, or medifixed, occasionally dark-pigmented, unicellular hairs minute (less than 0.5) to more than $2 \mathrm{~mm}$ long. Leaves distichous, imparipinnate, estipellate, or rarely with minute evanescent stipellae, with or without a variably developed pulvinus, and with the rhachis below the lowest leaflet (the petiole) somewhat variable but often consistently long or short; rarely reduced or deciduous. Leaflets few (rarely one) to numerous (over 40), fewer and often broader on young plants and on stem bases; occasionally reduced or absent, entire, sometimes somewhat turgid, the venation curved inside the margin and usually inconspicuous, petiolulate with the petiolule usually pubescent, opposite, to irregularly alternate, minute to over $3 \mathrm{~cm}$ long, often but not always decreasing in size towards the leaf-apex with the terminal sometimes conspicuously longer than the upper laterals but often irregular in its development; all mostly broadly to narrowly elliptic or broader above or below the middle, occasionally orbicular or cuneate, the apex occasionally acute but usually obtuse, retuse or emarginate, often with a central point and occasionally almost tridentate, the pubescence usually similar to that of the stem, often limited to the lower surface or if also on the upper often more sparse there; only occasionally absent from both surfaces. Stipules green or scarious, minute to several centimetres long, occasionally with pairs of unequal size, erect or recurved, usually ovate-deltoid, often with a long-extended tip, frequently oblique, entire or with teeth on one or both margins, occasionally with the margins erose, usually with at least some marginal hairs or pubescent on one or both surfaces, only occasionally joined to the petiole-base but sometimes with the outer margin obviously extended down the stem and often with the inner margin extended to join with that of the opposing stipule to form an abaxial ridge or collar; frequently with this ridge variably developed, confined to basal nodes or absent. Inflorescence an axillary raceme with few to many bracteate flowers on erect peduncles from less than 5 to more than $30 \mathrm{~cm}$ long with the lower flowers opening well before to almost simultaneously with the upper, sometimes the flowers extending over most of the peduncle but usually restricted to the top $2 / 3$ or less, occasionally subumbellate, and rarely 
with the terminal flowers aborted, usually the number of flowers and the pedunclelength correlated (c. 1 flower per centimetre) but occasionally with more spaced or dense flowers. Peduncle erect but often becoming decumbent when in fruit, usually longer than the leaves and from less than 0.5 to more than $5 \mathrm{~mm}$ wide, usually tapering and sometimes narrowed in the flowering region, almost always stouter than the leaf-rhachis, frequently with a basal pulvinus that is very conspicuous and often dark in many species, obscure and erratic in a few, and absent in others; glabrous or with a pubescence more dense and sometimes darker in the flowering region and usually related to that of the stem; usually longitudinally ridged below variable extensions bearing the pedicels and their subtending bracts. Bracts usually scarious, occasionally green and leaf-like, usually ovate to lanceolate, mostly shorter, occasionally longer, than the pedicel, often 1-2 mm long but reaching $4 \mathrm{~mm}$ or more in some species. Flowers papilionaceous but with petals variable in their relative lengths, pedicellate and with a short bracteolate hypanthium below the calyx; from a few millimetres to several centimetres long, mostly purple but occasionally white, pink, yellow, orange, red or, infrequently, particoloured, often changing colour with age or on drying, the pedicels slender, sometimes very short, rarely more than half the flower-length, those of the lower flowers being usually somewhat longer than those of the upper, usually pubescent with hairs often more dense and dark than those of the peduncle. Hypanthium usually shortly obconic and bearing two usually very small, occasionally larger, bracteoles, often tending to contract below the calyx as the flower matures, in one species with a distinct spiral twist. Calyx in general campanulate but with gradual or sudden and often oblique expansion above the hypanthium and sometimes a slight contraction below the calyx-lobes, glabrous to densely, sometimes dark, pubescent and usually with at least some hairs on the inner surface, the lobes virtually equal, or, in some species, the upper broader and somewhat shorter than the lower, mostly deltoid to long-deltoid, occasionally ovate or even lanceolate, sometimes with long-attenuate tips, shorter to much longer than the tube, the sinuses between the lobes narrowly deltoid to broadly curved. Standard usually longer than the wings and sometimes longer than the keel, usually, but not invariably (occasionally the flowers cleistogamous) raised from above the base at maturity and somewhat variably recurving, or even reflexed, often with the margins recurving, broader or narrower than long, contracting to a variable claw or tapering to the base, often with a plicate central groove, usually with but often without basal thickening, occasionally with a dished area above the thickening, rarely with a convex distortion; glabrous. Wings of equal size and shape, usually but not invariably appearing shorter than the other petals, obovoid or oblong to almost deltoid, often curved, the wing-apex from very broadly rounded, sometimes with a marginal band of thin tissue, to acute, and often oblique, the auricle mostly from truncate to recurved, the claw usually distinct, tapering, curved and somewhat less than $1 / 3$ of the petal-length, often with a fold or irregularity near the auricle; all glabrous or with occasional hairs inconsistent in their occurrence. Keel petals fused or free only at the extreme base or minutely at the extreme apex; laterally compressed and in lateral view varying in depth and curvature, often somewhat semicircular, tapering at the base to a long or short variously defined claw and rounded, tapering or even retracted at the apex, the tip often modified, sometimes beaked or rather porrect or lipped, often with a somewhat expanded area behind or below, rarely with two bosses or horn-like extensions, often with the tip raised and occasionally attenuate and recurving or recoiling, frequently with a slight to strong lateral twist near the apex or in the central region, the auricles variable in depth and disposition, the pockets or folds near the claw often well-defined and distinct but frequently variable, obscure, indefinite or absent; glabrous or, rarely, with small areas of pubescence. Stamens diadelphous, of alternating length, with the 9 joined stamens fused for a variable amount of 
their lengths but with the lowest always joined furthest, the anthers uniform and with separate cells. Ovary in lateral view usually obovate, elliptic, oblong or ovate, often conspicuously oblique at one or both ends, sometimes curved, at the base tapering to a long or short, rarely negligible or absent, stipe and at the apex usually tapering, occasionally untapered, behind the style-base, glabrous or pubescent with minute to long hairs, the pubescence often variable in extent within species and occasionally carried onto the stipe and/or style-base. Ovules usually numerous, occasionally c. 12 or 8 , with many failing to develop into seeds, in two rows along the sutural margin but occasionally absent from the ends of the loculus, the funicles slender, often flattened and frequently joined for a little or much of their length by a thin tissue, sometimes with the tissue deepest in the centre and shallow at or absent from the ends of the loculus. Style of variable length from shorter than to much longer than the ovary, usually laterally flattened, tapering from the often broad, occasionally much expanded, base to the tip or, rarely, untapered or broader above the base, sometimes unthickened, usually somewhat, often much, thickened and pale in colour in the upper $2 / 3$ and occasionally also at the base, usually strongly upwardly curved especially near the base, often more gradually or, rarely, uncurved or slightly recurved in the upper part, frequently somewhat spirally twisted, sometimes flattened on the adaxial surface or with some lateral and occasionally also dorsal expansion in the upper part, rarely with a thin wing-like longitudinal extension variably developed on the abaxial side, usually with a beard of variable length, density and texture on all or the upper part of the adaxial surface, the stigma small, terminal or lateral on an often much modified tip, the tip slender to relatively broad and often then truncate, straight, flexible and of indefinite direction, incurved, often very strongly, or geniculate, often with a narrow, minute, laterally extended section, frequently with a tuft or row of hairs extending longitudinally behind the tip on the abaxial side or laterally around it. Fruit a legume, usually 1 to more than $5 \mathrm{~cm}$ long and from almost spherical to narrowly cylindrical, often curved, sometimes laterally compressed but usually somewhat or much inflated, and rather dorsiventrally compressed, often with the adaxial suture intruded into the loculus, sometimes so as to render the fruit bilocular, rarely also with an abaxial intrusion, the apex from broadly obtuse to narrowly acute, often tapering obliquely and often with a small straight or erect beak bearing the recurved and often twisted style or its remains, the base variously and often obliquely narrowing to an occasionally elongating stipe, rarely irregularly shed from the apex of the stipe, with the funicular tissue, if present, deep or shallow, often closing the loculus or, when the suture is deeply intruded, folded upward into the loculus; variable in texture from delicate to almost woody, the dehiscence absent, tardy, on both margins but with little distortion of the valves or, most frequently, along the upper margin, rarely with the fruit splitting into two parts, the texture rarely papery or thinly membranous, usually softly to stiffly leathery, occasionally rigid and rather woody, the surface smooth or raised above the veins into a reticulation or into strong ridges, the venation at an angle of $30^{\circ}-90^{\circ}$ to the lower margin, the pubescence, when present, from minute, spaced and appressed to densely woolly or villose, the hairs sometimes arising from minute tubercles on the fruit-surface; at maturity fruits lifted to a horizontal or, more frequently, erect position, rarely pendulous, usually not, or only tardily, shed. Seeds usually numerous, occasionally few, reniform and, for most species, not seen mature; smooth or somewhat indented, dark or light coloured with minute dark spots, the surface and colour variable within species; size varying with the often considerable amount of abortion within the loculus, occasionally all seeds of a fruit aborted. $2 n=32$ in those relatively few species counted.

A genus of 85 species, of which 84 are endemic in Australia and one in New Zealand. 


\section{Key to species}

1 Stem-hairs basifixed, laterally attached at the base or absent

2 Stem-hairs fine-tipped, with most $1 \mathrm{~mm}$ or more long, straight or curved, and spreading

3 Plant erect and to $50 \mathrm{~cm}$ or more high

4 Flowers $20-30 \mathrm{~mm}$ long

18. S. maccullochiana

$4^{*}$ Flowers to $15 \mathrm{~mm}$ long

5 Flowers 8-10 mm long; stipules well separated at the back

16. S. decurrens

$5^{*}$ Flowers mostly $10-15 \mathrm{~mm}$ long; stipules usually close at the back

14. S. elegantoides

$3^{*}$ Plant spreading and up to $\mathrm{c} .30 \mathrm{~cm}$ high

6 Flowers mostly $50-60 \mathrm{~mm}$ long

19. S. formosa

6* Flowers less than $25 \mathrm{~mm}$ long

7 Peduncle pulvinate

8 Leaflets usually 5 ; stipules to c. $7 \mathrm{~mm}$ long

22. S. longipilosa

$8^{*}$ Leaflets more than 5 ; stipules usually more than $10 \mathrm{~mm}$ long

9 Leaflets 15-19, their hairs loosely appressed

20. S. beasleyana

9* Leaflets $7-11$, their hairs spreading

24. S. calcicola

7* Peduncle epulvinate

26. S. villosa

$2^{*}$ Stem-hairs various but if more than $0.75 \mathrm{~mm}$ long then twisted or crisped and not strongly divergent, or reversed at the base

10 Fruit-texture woody or almost so, with the surface ridged

11 Fruit strongly curved

12 Leaflets 1-7

32. S. cyclocarpa

$12^{*}$ Leaflets $9-13$

33. S. halophila

$11^{*}$ Fruit little, if at all, curved

13 Fruit with boss-like peaks on the ridges

31. S. paradoxa

$13^{*}$ Fruit without boss-like peaks on the ridges

14 Style-base narrow

27. S. rostellata

$14^{*}$ Style-base broad

15 Leaflet-apex deeply retuse or emarginate

29. S. gracilis

15* Leaflet-apex rounded to shallowly emarginate

30 S. pterostylis

$10^{*}$ Fruit texture various, but if somewhat woody then not ridged

16 Wings strongly curved, with a large obtuse extension

35. S. campylantha

$16^{*}$ Wings various, but if curved then without a large, obtuse extension

17 Keel with 2 extensions near the apex

18 Extensions awl-shaped

21. S. cornuta

$18^{*}$ Extensions boss-like

70. S. canescens

$17^{*}$ Keel without extensions near the apex

19 Keel narrowed, upwardly extended and twisted or curled 
20 Keel-tip upwardly directed; style less than $10 \mathrm{~mm}$ long, unbearded and with a ridge of hairs behind the style-tip 74. S. plagiotropis

$20^{*}$ Keel-tip recurved or curled; style more than $10 \mathrm{~mm}$ long, bearded and with few or no hairs behind the style-tip

21 Stem-hairs c. $0.5 \mathrm{~mm}$ long, spreading; keel not making a full circle

75. S. swainsonioides

21* Stem-hairs minute, appressed; keel forming a circle

76. S. procumbens

19* Keel various but never upwardly extended and twisted or curled

22 Peduncle with the pulvinus absent or obscure

23 Stipe c. $1 \mathrm{~mm}$ or more long, or, if somewhat less, then the fruits strongly bilaterally compressed

24 Stipules usually forming an abaxial ridge

25 Leaflets mostly more than 13

26 Stems glabrous or with spreading crisped hairs

27 Calyx-lobes very long and long-attenuate

28 Calyx glabrous or puberulent at the base

5. S. sejuncta

$28^{*}$ Calyx with a short crisped pubescence

8. S. cadellii

$27^{*}$ Calyx-lobes equal to or shorter than the tube, deltoid to shortly acuminate

29 Plant annual, $1 \mathrm{~m}$ or more high; stipules often to $\mathrm{c} .15 \mathrm{~mm}$ long; flowers purple

1. S. colutoides

29* Plant perennial, short or tall; stipules often less than $8 \mathrm{~mm}$ long and if more then the flowers yellow

30 Stipules broadly and obliquely ovate; flowers yellow

2. S. pyrophila

$30^{*}$ Stipules deltoid to long-deltoid; flower-colour various

31 Calyx with a white-woolly pubescence

9. S. greyana

$31^{*}$ Calyx glabrous or, if hairy then the pubescence not white-woolly

32 Stems glabrous; pedicels often 5-10 mm long, glabrous

4. S. galegifolia

$32^{*}$ Stems pubescent or, if glabrous, the pedicels less than $5 \mathrm{~mm}$ long and not glabrous

33 Bracts usually 1-2 mm long; pedicels minutely puberulent

6. S. queenslandica

33* Bracts often 8-10 mm long; pedicels pubescent

7. S. bracteata

$26^{*}$ Stems with scattered minute, usually appressed hairs

10. S. fraseri

$25^{*}$ Leaflets mostly 13 or fewer

34 Leaflets usually 1-3

40. S. unifoliolata

$34^{*}$ Leaflets $5-13$

35 Stipules c. $1 \mathrm{~mm}$ long, without an auricle-like extension at the base

11. S. brachycarpa 
$35^{*}$ Stipules to $5 \mathrm{~mm}$ or more long, with an auricle-like extension at the base

36 Bracteoles conspicuous; fruit veins at c. $30^{\circ}$ 37. S. viridis

$36^{*}$ Bracteoles minute; fruit veins at $60^{\circ}-90^{\circ}$.

38. S. perlonga

$24^{*}$ Stipules not, or only occasionally, forming an abaxial ridge

37 Stipules usually $8 \mathrm{~mm}$ or more long, with an auricle-like extension at the base

38 Stipules toothed; style c. $7 \mathrm{~mm}$ long

41. S. tanamiensis

$38^{*}$ Stipules not or scarcely toothed; style 2-3 $\mathrm{mm}$ long

36. S. kingii

$37^{*}$ Stipules usually less than $8 \mathrm{~mm}$ long, without an auricle-like extension at the base

39 Stem-hairs dense or, if sparse, loosely divergent

40 Flowers c. $20 \mathrm{~mm}$ long, on puberulent pedicels c. $5 \mathrm{~mm}$ long

17. S. ecallosa

40* Flowers 9-12 $\mathrm{mm}$ long, on densely pubescent pedicels $2-3 \mathrm{~mm}$ long

15. S. forrestii

39* Stem-hairs sparse or absent or if rather dense then appressed

41 Plant perennial and shrublike with the leaflets often reduced or absent; flowers yellow

3. S. laxa

41* Plant a tall 1- to few-stemmed annual; leaflets not reduced; flowers purple to dark red

42 Stems with broad flat or turgid hairs; flowers 4-7 $\mathrm{mm}$ long

13. S. complanata

42* Stems glabrous or with fine hairs; flowers c. $10 \mathrm{~mm}$ long

12. S. stenodonta

$23^{*}$ Stipe to $0.5 \mathrm{~mm}$ long; fruit not as above

43 Stipules to c. $10 \mathrm{~mm}$ long, broad-based, broader than long, usually toothed and with appressed hairs on the upper surface.

42. S. laciniata

$43^{*}$ Stipules not as above

44 Style 1-1.5 mm long; fruit pubescent and/or much longer than wide

45 Flowers $3-5 \mathrm{~mm}$ long

46 Stem-hairs minute; leaflets 9-13

44. S. oliveri

46* Stem-hairs often c. $0.75 \mathrm{~mm}$ long; leaflets $5-7$

45. S. leeana

45* Flowers 6-8 $\mathrm{mm}$ long

43. S. luteola

$44^{*}$ Style $3 \mathrm{~mm}$ or more long or, if a little less, then the fruit glabrous and almost globular

47 Fruit c. 10 times as long as broad; keel much longer than the other petals

39. S. longicarinata

$47^{*}$ Fruit globular, to c. 3 times as long as broad; keel not longer than the other petals

48 Fruit with a soft pubescence

49 Fruit almost spherical, with a rather woolly pubescence

73. S. burkittii

49* Fruit $11 / 2-3$ times longer than broad, with a spreading pubescence

50 Leaflet-apex acute to acuminate; plant usually annual

71. S. incei 
$50^{*}$ Leaflet-apex obtuse to retuse; plant perennial

51 Keel beaked, narrow and conspicuously twisted; style-tip incurved

69. S. acuticarinata

$51^{*}$ Keel not beaked, narrow and conspicuously twisted; style-tip geniculate

52 Calyx-lobes narrow; keel greenish yellow 65. S. flavicarinata

52* Calyx-lobes broad, keel not greenish yellow

64. S. disjuncta

48* Fruit glabrous or with spaced appressed hairs

53 Plant annual; stipules not forming an abaxial ridge

50. S. extrajacens

$53^{*}$ Plant perennial; abaxial ridge present or absent

54 Fruit at least twice as long as broad; ovary and fruit pubescent

55 Raceme c. $5 \mathrm{~cm}$ long or less, usually few-flowered

54. S. novae-zelandiae

55* Raceme 10-20 cm long, with numerous flowers

53. S. lessertiifolia

$54^{*}$ Fruit less than twice as long as broad; ovary and fruit glabrous

56 Leaflets mostly very narrowly linear-lanceolate

48. S. recta

$56 *$ Leaflets not narrowly linear-lanceolate

57 Leaflets usually 7-25; style-tip narrowing from the top with the narrowed piece variously extended

51. S. affinis

57* Leaflets usually 21-41; style-tip usually truncate

52. S. microphylla

22* Peduncle with a conspicuous, often dark-coloured, pulvinus

58 Style-tip conspicuously tufted

59 Leaves with 11-25, usually emarginate, leaflets

47. S. monticola

$59 *$ Leaves with 5-15, usually acute or obtuse, leaflets

60 Plant erect or ascending; leaflets mostly 5-8 $\mathrm{mm}$ long

49. S. similis

$60^{*}$ Plant low-growing, leaflets mostly $10-25 \mathrm{~mm}$ long

46. S. parviflora

$58^{*}$ Style-tip not tufted

61 Style-tip slender and lacking a geniculate segment

62 Stipules often $10 \mathrm{~mm}$ long and with numerous lateral teeth

25. S. elegans

$62^{*}$ Stipules usually only to $5 \mathrm{~mm}$ long, without teeth

63 Stem-hairs few to dense, $0.5-0.75 \mathrm{~mm}$ long and fine-pointed

23. S. pedunculata

63* Stem-hairs few, minute and broadly acute

34. S. dictyocarpa

$61^{*}$ Style-tip with a geniculate segment, or broad

64 Style-tip with a geniculate segment

65 Stems prostrate or occasionally ascending; calyx with narrow sinuses

66 Leaflets 3-7, the terminal much longer than the laterals

67 Ovary- and fruit-pubescence rather short; fruit not much longer than broad

55. S. oroboides

$67^{*}$ Ovary- and fruit-pubescence very long; fruit much longer than broad 
$66^{*}$ Leaflets 5-15, the terminal variable in relation to the laterals

68 Calyx-lobes much longer than the tube

57. S. tenuis

$68^{*}$ Calyx-lobes scarcely longer than the tube

69 Stipules rarely forming an abaxial ridge; style with a broad wing-like translucent tissue in the upper part

58. S. reticulata

69* Stipules usually forming an abaxial ridge; style with the translucent tissue not broad and wing-like

59. S. behriana

$65^{*}$ Stems erect or occasionally ascending; calyx-sinuses rather broad

70 Stem-hairs c. $0.5 \mathrm{~mm}$ long; calyx-lobes a little shorter than the tube

60. S. campestris

$70^{*}$ Stem-hairs mostly $0.75-1.5 \mathrm{~mm}$ long; calyx-lobes a little longer than the tube 61. S. vestita

64* Style-tip very broad, incurved or inflexed

71 Stipules broad, usually obliquely ovate

67. S. burkei

$71^{*}$ Stipules usually narrowly deltoid

68. S. rostrata

$1^{*}$ Stems with at least some hairs medifixed

72 Keel conspicuously longer than the wings

63. S. phacoides

72* Keel and wings of similar length

73 Stipules broad, to $15 \mathrm{~mm}$ long, toothed

74 Style-tip with a short, usually curved, extension

85. S. eremaea

$74^{*}$ Style-tip without an extension

84. S. stipularis

$73^{*}$ Stipules narrowly deltoid to narrowly lanceolate or linear, their length various but not more than $10 \mathrm{~mm}$; not toothed

75 Style $1-2 \mathrm{~mm}$ long

76 Fruit almost circular, woody in texture

28. S. rotunda

76* Fruit long and narrow, thinly leathery in texture

82. S. minutiflora

75* Style $4 \mathrm{~mm}$ or more long

77 Calyx-lobes long-attenuate and several times longer than the tube

66. S. oligophylla

77* Calyx-lobes deltoid, occasionally acuminate, shorter or a little longer than the tube

78 Fruit subglobose; peduncle epulvinate

72. S. tephrotricha

78* Fruit much longer than broad; peduncle pulvinate

79 Style unthickened at the base, the tip with a slender geniculate segment

62. S. sericea

79* Style thickened at the base, the tip various but not conspicuously geniculate

80 Hypanthium conspicuously twisted

78. S. murrayana

80* Hypanthium not conspicuously twisted

81 Flowers usually $12-14 \mathrm{~mm}$ long; style long and tapering to a fine tip

77. S. purpurea

$81^{*}$ Flowers to $10 \mathrm{~mm}$ long, style not long and tapering to a fine tip 
82 Stem-hairs c. $1 \mathrm{~mm}$ long, loosely appressed or with the ends raised; style with a minute extension

79. S. fissimontana

$82^{*}$ Stem-hairs c. $0.5 \mathrm{~mm}$ long, appressed or, if with the ends raised, the style-tip incurved to inflexed

83 Leaflet with a conspicuous apical gland

83. S. adenophylla

$83^{*}$ Leaflet-apex lacking a conspicuous gland

84 Keel-apex narrow and upcurved; fruit less than 3 times as long as wide

80. S. fuscoviridis

$84^{*}$ Keel-apex not as above; fruit more than 3 times as long as wide

81. S. microcalyx

\section{Putative natural groups}

Within Swainsona there are sets of obviously related species. Some of these species are related by apomorphies, some show the apparent retention of primitive characters, but the scope of this work has not allowed me to place every species with confidence or to determine a phylogenetic hierarchy within the genus. Possibility of error is enhanced by the likelihood that some apomorphies are shared by species that are not very closely related. I have grouped species tentatively here but have not provided descriptions of groups since I acknowledge that we do not yet know enough about the sub-generic structure of the genus. The key provided here allows indication of major synapomorphies and an overview of the morphological differences within the genus that may provide a useful basis for further study. The keys to species within groups draw attention to the diversity and the apomorphies within what are, at least for the most part, natural assemblages.

\section{Key to species-groups}

1 Plants $50 \mathrm{~cm}$ to more than $1 \mathrm{~m}$ high; annual or perennial, usually single-stemmed or shrublike and erect (prostrate only in S. brachycarpa); stems glabrous or with basifixed hairs; peduncle epulvinate; fruit laterally or somewhat dorsiventrally compressed; funicular tissue absent or very short or if well-developed then the plants annual; fruit-stipe more than $1 \mathrm{~mm}$. long or if c. $1 \mathrm{~mm}$ then the fruit strongly laterally compressed and the funicular tissue absent

2 Stipules joined to form an abaxial ridge or if not then the flowers yellow and leaflets often reduced or absent; flowers mostly c. $10 \mathrm{~mm}$ or more long; ovary glabrous or minutely pubescent; fruit with the funicular tissue absent or very short and even GROUP 1 (Species 1-11)

$2^{*}$ Stipules not forming an abaxial ridge or if occasionally forming a ridge then the ovary long-pubescent; flowers large or small; ovary variously pubescent at least in part; fruit with funicular tissue deep but only in the centre of the sutural margin or if absent then the flowers very small and crowded

GROUP 2 (Species 12-18)

$1^{*}$ Plants low-growing or short or if reaching $50 \mathrm{~cm}$ or more then the stem-hairs medifixed and/or the fruit-stipe very short; stem-hairs basifixed or medifixed; peduncle with or without a pulvinus; fruit variously or not compressed; funicular tissue at least somewhat, mostly well, developed or if absent then the style geniculate or the plant short and rhizomatous 
3 Stem-hairs long, slender and basifixed or if some shorter then the peduncles straw-like; stipules large but not forming an abaxial ridge; style slender and unstiffened and not tufted, or if tufted then with a characteristic obliquely truncate tip with an antrorse arc of hairs GROUP 3 (Species 19-26)

$3^{*}$ Stem-hairs long or short, slender or broad, basifixed or medifixed; stipules large or small but if large then forming an abaxial ridge or if not then the stem hairs short and/or medifixed or the style stout and thickened; style stout or slender, thickened or unthickened, tufted or untufted

4 Fruit-stipe usually c. $1 \mathrm{~mm}$ long but occasionally shorter and then the stipules broad, toothed and tending to extend down the stem or the keel much longer than the other petals or the wings with an obtuse extension or the peduncle pulvinate and the fruitsurface sculptured; stem-hairs sparse, minute and basifixed or if dense and longer then the fruit very narrowly cylindrical and soft and if medifixed then the fruit small, almost circular and acutely ridged

5 Fruit-texture somewhat to very woody with the surface raised in acute ridges, the tissue deep and closing the loculus; stem-hairs basifixed or medifixed

6 Fruit to $10(-12) \mathrm{mm}$ long, usually little if at all longer than broad, round to oblong, strongly dorsiventrally compressed, contracted at the apex or if tapered then the style c. $1 \mathrm{~mm}$ long; keel conspicuously twisted or if not then the stemhairs medifixed; style-tip with 2 spaced lines of short hairs and/or conspicuously laterally flattened; stem-hairs basifixed or medifixed

GROUP 4 (Species 27-30)

$6^{*}$ Fruit 10-20 mm long, usually longer than broad but if not then ovoid; not dorsiventrally compressed; tapering to a conspicuous beak-like apex bearing a style 3-4 mm long; keel straight; style with an antrorse line of hairs behind the tip which is not flattened; hairs basifixed

GROUP 5 (Species 31-33)

$5^{*}$ Fruit-texture soft to leathery or if somewhat woody then the surface smooth or with raised reticulation, the tissue obvious, deep or shallow and even; stem-hairs basifixed

GROUP 6 (Species 34-42)

$4^{*} \quad$ Fruit-stipe usually $0.5 \mathrm{~mm}$ or less; stem-hairs dense or sparse, minute to long, basifixed or medifixed; fruit-texture not woody

7 Fruit narrowly to broadly subelliptic and bearing a $1-1.5 \mathrm{~mm}$ style at the apex; flowers inconspicuous and if as long as $8 \mathrm{~mm}$ then the fruit narrow; standard often failing to lift; stem hairs basifixed

GROUP 7 (Species 43-45)

$7^{*}$ Fruit various; style $2 \mathrm{~mm}$ or more long or if shorter then the fruit broad; flowers usually conspicuous but if small and inconspicuous then the stem-hairs medifixed or the style c. $4 \mathrm{~mm}$ long; standard lifting or if not then the stem-hairs medifixed; stem-hairs basifixed or medifixed

8 Keel acute, often with a beak-like tip; plant annual or perennial; style 3-4 mm long, not twisted and with hairs behind the stigma; stem-hairs short and basifixed or if long then the plant annual .................... GROUP 8 (Species 46-50)

$8^{*}$ Keel not acute or beak-like or if so then the stem-hairs long or medifixed; plant probably perennial; style various as to length, twisted or not twisted and with or without hairs behind the stigma; stem-hairs basifixed or medifixed

9 Leaflets usually more than 15; flowers $10 \mathrm{~mm}$ or less long; fruit inflated, very broad, short and glabrous or, if more than $10 \mathrm{~mm}$ long then with spaced short, closely appressed hairs; stem-hairs basifixed GROUP 9 (Species 51-54)

9* Leaflets usually fewer than 15 or, if more than 15 then the fruit not as above; flower-length various; stem-hairs basifixed or medifixed

10 Stem-hairs basifixed or if medifixed then the style not strongly thickened from at or near the base 
11 Style-tip without a tuft, unmodified or with a distinct geniculate segment GROUP 10 (Species 55-63)

11* Style-tip various but if geniculate then with a tuft of hairs behind the terminal segment

12 Keel-apex modified or unmodified but never strongly upcurved and twisted

GROUP 11 (Species 64-73)

12* Keel-apex narrowed, strongly upcurved and twisted GROUP 12 (Species 74-76)

$10^{*}$ Stem-hairs medifixed; style strongly thickened from at or near the base GROUP 13 (Species 77-85)

\section{Group 1}

1 Plant $50 \mathrm{~cm}$ to more than $1 \mathrm{~m}$ high, annual or perennial; stems glabrous or pubescent

2 Plant annual; stipules broad and often $15 \mathrm{~mm}$ or more long

1. S. colutoides

$2^{*}$ Plant perennial; stipules broad or narrow, and less than $8 \mathrm{~mm}$ long

3 Stems glabrous or with spreading crisped hairs

4 Calyx glabrous or sparsely or densely pubescent but if densely pubescent then the pubescence not white-woolly and the lobes approximately equal to the tube

5 Calyx-lobes much longer than the tube and long-acuminate to long-aristate

6 Calyx glabrous or puberulous at the base; style c. $10 \mathrm{~mm}$ long 5. S. sejuncta

6* Calyx with a very short crisped pubescence; style c. $4 \mathrm{~mm}$ long

8. S. cadellii

$5^{*}$ Calyx-lobes equal to or much shorter than the tube, acute to long-acuminate

7 Stipules deltoid to long-deltoid, flower-colour various; standard with 2 basal calli; style without a tuft (occasionally with a few hairs) behind the tip

8 Stems glabrous; pedicels often $5-10 \mathrm{~mm}$ long, virtually glabrous

\section{S. galegifolia}

$8^{*}$ Stems pubescent or, if glabrous then the pedicels mostly less than $5 \mathrm{~mm}$ long and minutely pubescent or puberulent

9 Bracts usually 1-2 mm long; pedicels minutely puberulent

9* Bracts often 8-10 mm long; pedicels pubescent

6. S. queenslandica

7. S. bracteata

$7^{*}$ Stipules broadly and obliquely ovate; flowers yellow; standard without calli; style with a tuft of hairs behind the tip

2. S. pyrophila

$4^{*}$ Calyx with a dense white woolly pubescence, the lobes usually much shorter than the tube

9. S. greyana

$3^{*}$ Stems with scattered, minute, usually appressed hairs

10 Stipules not forming an abaxial ridge; flowers yellow

3. S. laxa

$10^{*}$ Stipules forming an abaxial ridge; flowers pink-purple

10. S. fraseri

$1^{*}$ Plant prostrate or low-growing, rarely more than $10 \mathrm{~cm}$ high, perennial; stems glabrous or with scattered tubercles occasionally bearing minute hairs

11. S. brachycarpa 


\section{S. colutoides F. Muell.}

(F. Mueller 1876: 6)

TyPe: WeStern Australia: between Ularing and Mt Jackson, Young; lecto (fide Lee 1948) MEL.

An erect, usually several-stemmed, annual, $1-1.3 \mathrm{~m}$ high, and with a simple taproot. Stems often very stout, frequently more than $5 \mathrm{~mm}$ wide, terete or strongly angled, glabrous. Leaves often 15-20 cm long, with 13-17 leaflets above a short petiole, the leaflets obovate, glabrous, the lower to $10-30 \mathrm{~mm}$ long and to $15 \mathrm{~mm}$ wide, the terminal somewhat longer than the shorter upper laterals, the leaflet-apex rounded to somewhat emarginate and without a point. Stipules often $15 \mathrm{~mm}$ or more long, ovatedeltoid, about twice as long as wide, the tip often rounded, the base oblique and auricled, green, joined across the back to form an abaxial ridge and with a few hairs on the margins. Racemes mostly c. $15 \mathrm{~cm}$ long, with c. 15 flowers of uneven age. Peduncle 1.5-2 mm wide, without a pulvinus, with flowers in the upper $2 / 3$, strongly ribbed, glabrous. Bracts ovate or variably attenuate, c. $3 \mathrm{~mm}$ long. Flowers purple, $15-$ $20 \mathrm{~mm}$ long, on glabrous pedicels c. 3-4 mm long. Hypanthium rather narrow and contracting conspicuously at the apex under the fruiting calyx, the bracteoles small and oblong-deltoid. Calyx with the tube 3-4 $\mathrm{mm}$ long, much and obliquely expanded above the hypanthium, glabrous, the lobes deltoid to long-deltoid, shorter than the tube, with the lowest rather longer than the upper pairs, the sinuses rather narrow and acute. Standard 15-20 mm long and up to $15 \mathrm{~mm}$ wide, variously tapering to the base, with two large plate-like calli in the lower part. Wings (Fig. 4) 11-14 mm long, narrowly elliptic-oblong and rather narrowly obtuse, the claw short, tapering and somewhat curved, the auricle deep and long. Keel 15-20 mm long and c. $6 \mathrm{~mm}$ deep, with the apex somewhat obtuse and obscurely lipped, with the upper margin almost straight or curved near the tip, and often with indistinct swellings near the base, the claw short, scarcely tapered and slightly curved, the auricles deltoid and rather deep. Ovary c. $7 \mathrm{~mm}$ long, narrowly elliptic, curved, glabrous, the apex slender, tapering to the slender style-base, the base tapering and rather oblique. Ovules numerous. Stipe 3-5 mm long, slender, glabrous. Style (Fig. 6) slender, thin-textured, laterally compressed, gradually and evenly tapered to a slender straight or curved tip, with fine antrorse hairs behind the tip, not twisted, the curvature even or strong near the tip, the beard fine, long and even, and over most of the length. Fruit (Fig. 7) mostly 30$40 \mathrm{~mm}$ long and c. $15 \mathrm{~mm}$ wide, lunate, with the suture often curved at least near the apex, much inflated, with the suture not or only broadly intruded, tapering at the base to an often tapering, narrow stipe 3-7 mm long, and at the apex to an acute or acuminate, stiff and sometimes upturned, beak-like tip often bearing the recurved c. $9 \mathrm{~mm}$ style or its base, spreading or upcurved at maturity, apparently indehiscent, glabrous, the texture thin and papery, the veins very delicate and at c. $90^{\circ}$, the tissue absent.

In inland parts of southern Western Australia and South Australia, in the Northern Territory near Alice Springs and in the south-western corner of New South Wales. Usually on sandy flats or in skeletal hillside soils in mallee woodland; usually found only after fire. Fig. 8.

Selected specimens (from c. 60 examined): Western Australia: Trayning, Stoward 109 (BM); Victoria Desert near camp 54, Helms, 17 Sep 1891 (K, MEL, NSW). NORTHERN TERRITORY: $1 \mathrm{~km}$ NNW of Reedy Rockhole, Latz 8726, 16 July 1981 (CBG, K, NSW, NT). SOuTH Australia: Danggali Conservation Park, $11 \mathrm{~km}$ E of 'Hypurna' H.S., Jennings, 1 Jan 1982 (AD). New SourH WALES: 'Tarawi', c. $80 \mathrm{~km}$ N of Murray River along NSW/SA border, Bawden per Mulham 1542, Nov 1984 (NSW). 


\section{S. pyrophila J. Thompson}

(J. Thompson 1991: 359)

TYPe: SOUTH Australia: Hambidge Reșerve, Eyre Peninsula, D. Symon 4288, 10 Oct 1966; holo NSW; iso AD, CANB, K.

\section{[S. laxa auct. non R. Br.]}

An erect, subshrubby, several-stemmed perennial to c. $1 \mathrm{~m}$ high, with a strong taproot, and often with stem-bases below the soil surface. Stems often $5 \mathrm{~mm}$ or more in width, ribbed and usually somewhat angled near the nodes, conspicuously flexuose, almost glabrous, at most with a few minute, blunt, loose, basifixed flat hairs. Leaves 5-15 cm long, with c. 17 leaflets above a short petiole, the leaflets obovate-oblong, glabrous, the lower mostly 10-25 mm long and 4-12 $\mathrm{mm}$ wide, the terminal variable but often a little larger than the shorter upper laterals, the leaflet-apex broad and slightly to conspicuously emarginate, sometimes with a blunt point. Stipules $4-7 \mathrm{~mm}$ long, occasionally to $>10 \mathrm{~mm}$, conspicuous, broadly and obliquely ovate and usually very obtuse, green, joined in a sometimes very shallow abaxial ridge and often with minute marginal hairs. Racemes $15-25 \mathrm{~cm}$ long, with 15-20 flowers of uneven age. Peduncle 1-2 mm wide, without a pulvinus, with flowers on $2 / 3$ or more of its length, strongly ribbed, glabrous. Bracts broadly ovate, c. $1 \mathrm{~mm}$ long. Flowers yellow, c. $10 \mathrm{~mm}$ long, on sparsely and shortly pubescent pedicels 3-4 mm long. Hypanthium slender-based, conspicuously contracting at the apex under the fruiting calyx, the bracteoles very small. Calyx with the tube $1.5-2 \mathrm{~mm}$ long, strongly and obliquely expanding above the hypanthium, glabrous, the lobes deltoid and shorter than the tube, the upper a little broader, the sinuses usually rather narrowly rounded. Standard c. $7-10 \mathrm{~mm}$ long and as wide or a little wider, with the base tapering to a short tapered claw, without thickenings in the lower part. Wings c. $8 \mathrm{~mm}$ long, deltoidovate or occasionally obovate, somewhat curved, the apex narrowly to very broadly obtuse, the claw short, tapering and curved, the auricle long, narrowly rounded and somewhat curved. Keel 7-10 mm long and c. $5 \mathrm{~mm}$ deep, with the apex acute to broadly obtuse and the tip rather lipped or somewhat retracted, with the upper margin straight or curved, without folds at the base, the claw short and straight, the auricles rounded. Ovary $3.5-4 \mathrm{~mm}$ long, narrowly elliptic, curved, glabrous, the apex gradually tapering somewhat obliquely to a rather broad style-base, the base oblique and less gradually tapered. Ovules numerous. Stipe c. $2 \mathrm{~mm}$ long, very slender, glabrous. Style slender thin-textured, somewhat laterally compressed, slightly or scarcely tapered to the tip which is narrowed shortly from the top, with antrorse hairs on the narrow region, not twisted, the curvature even and rather shallow, the beard long and sparse especially in the lower part. Fruit usually 20-30 mm long and 10-15 mm wide, lunate to broadly elliptic, much inflated, with the suture often lower than the inflated sides, rather abruptly and obliquely contracting to a narrow and variably extended tapering base above a slender stipe 1-c. $4 \mathrm{~mm}$ long, and at the apex obliquely and suddenly contracting to a short raised and sometimes inset beak bearing the c. $3 \mathrm{~mm}$ recurved style or its remains, pendulous to erect at maturity, indehiscent or the dehiscence tardy and along the suture, glabrous, the texture thinly membranous, the veins obvious but delicate, at $90^{\circ}$, the tissue negligible.

In the south-eastern half of South Australia and along the Murray River valley into north-western Victoria and south-western New South Wales; with isolated occurrences northward. In sandy or loamy soil in mallee scrub; usually found only after fire. Fig. 8.

Selected SPEcimens (from c. 90 examined): South Australia: Hundred of Pinkawillinie, c. $36 \mathrm{~km}$ WNW of Kimba, Rohrlach 8, 15 Dec 1958 (AD, K); Eremophila Park, Spooner 6667, 21 Oct 1979 
(AD). New South Wales: off Sturt Highway between Euston \& Buronga, Mulham W966, Oct 1976 (NSW). VICTORIA: Kulkyne National Forest, Ramsay, 23 Nov 1952 (MEL); Walpeup, Williamson, Sep 1913 (MEL, NSW).

\section{S. laxa R. Br.}

(Brown in C. Sturt 1849: 18)

Trpe: Central Australia: C. Sturt, 1844-6; holo BM, Sturt Append. n. 8, No. 28, (2 sheets? one collection).

S. laxa var.? rigida Benth. (G. Bentham 1864: 224); S. rigida (Benth.) J. Black (J.M. Black 1927: 380). Type: New South Wales: near R. Darling, V.E.E., 31 Oct 1860; lecto (fide Lee 1948: 164) MEL; iso $\mathrm{K}$.

An erect or ascending, often almost leafless, subshrubby perennial to $2 \mathrm{~m}$ high but often less, with a slender and very long taproot and often densely branched stembases below the soil-surface. Stems very variable, up to $5 \mathrm{~mm}$ wide but sometimes not exceeding $1.5 \mathrm{~mm}$, terete and sometimes ribbed, often bluntly angled below the nodes, glabrous or with scattered short, rather elliptic, flat or turgid, pointed, appressed, basifixed hairs. Leaves mostly $5-15 \mathrm{~cm}$ long but often absent or present only as a rhachis, the leaflets often 13-17 and above an extended petiole, when present very variable, in general obovate, with spaced appressed flat hairs on the lower surface, the lower from minute to c. $10 \mathrm{~mm}$ long and up to $7 \mathrm{~mm}$ wide but usually much narrower, the terminal variable in relation to the somewhat shorter upper laterals, the leaflet-apex often deeply emarginate, lacking a point. Stipules minute, to c. $2 \mathrm{~mm}$ long, narrow at least in the upper part, green or scarious, often, but not invariably, lacking an abaxial ridge, and with marginal hairs. Racemes from 5 to more than $30 \mathrm{~cm}$ long, with c. 15-20 flowers of uneven age. Peduncle $0.5-3 \mathrm{~mm}$ wide, without a pulvinus, with flowers in the upper $2 / 3-1 / 3$ of its length, wrinkled rather than ribbed, with sparse, somewhat appressed, hairs, denser in the upper part. Bracts ovate, often narrowly so, c. $1 \mathrm{~mm}$ long. Flowers yellow, often with some purple shading especially on the wings, c. 10-15 mm long, on puberulous pedicels 2-3 mm long. Hypanthium short and broad, not contracting under the fruiting calyx, the bracteoles small and linear. Calyx with the tube c. 2-3 $\mathrm{mm}$ long, somewhat obliquely expanded above the broad hypanthium-top, glabrous or with a few short appressed hairs, the lobes shortly, often very shortly, deltoid, much shorter than the tube, the upper shortest, the sinuses broad and rounded. Standard c. 10-15 $\mathrm{mm}$ long and c. 6-10 mm wide, tapering to a narrow claw, with a conspicuous convex thickening in the lower part. Wings 6-10 mm long, ovately to obovately oblong, somewhat curved, broadly obtuse to, occasionally, broadly acute, the claw short, slender, tapering and curved, the auricle rather long, slender, rounded at the apex and somewhat curved. Keel 10-15 mm long and to c. $4 \mathrm{~mm}$ deep, with the apex narrowly obtuse and sometimes obviously beaked, with the upper margin straight or curved behind the apex, without folds near the base, the claw long, slender and straight, the auricles narrow and subdeltoid. Ovary 4-6 mm long, almost oblong-elliptic but broader towards the apex, glabrous, the apex gradually and somewhat obliquely tapering to the style, the base more obliquely and more suddenly tapered. Ooules numerous. Stipe 1-2 mm long, slender, glabrous. Style not very broad-based, a little stiffened in the upper part, laterally compressed, little and gradually tapered to a more slender but somewhat truncate apex with a broad tuft of antrorse hairs close behind it, not twisted, shallowly and evenly curved, the beard fine, often denser in the upper part. Fruit usually $15-20 \mathrm{~mm}$ long and c. $10 \mathrm{~mm}$ wide, very variable in shape but mostly irregularly and obliquely obovate-elliptic, often scarcely inflated but occasionally conspicuously so, with the suture not intrud- 
ed, at the base rounded or abruptly tapered, with or without a short narrow area, above a slender stipe of 1-2 mm, at the apex usually suddenly and obliquely contracting to a very short straight or upturned beak below a c. $3 \mathrm{~mm}$ style, pendulous to erect at maturity, dehiscent along the upper suture, glabrous, the texture mostly rather stiffly membranous, the veins obvious but delicate, at $90^{\circ}$, the tissue absent.

In the south-eastern corner of the Northern Territory and north-eastern South Australia, and scattered in south-western Queensland (with an unlikely record from the east coast) and western New South Wales. In sandy soil, especially on the upper slopes of sand-ridges. Fig. 8.

SeleCted SPECIMENS (from c. 45 examined): NoRTHERN TERRITORY: Northwest Simpson Desert, Latz 4378, 28 Sep 1973 (AD, CANB, NT). SoutH Australia: Northern end of Koonchera Dune, Donner 5123, 13 Aug 1975 (AD, BRI, CANB, MEL, NSW, PERTH); Lake Perigundi, Cooper Creek, Crisp 546, 1 June 1979 (AD, CBG). QuEENSLAND: c. 90 miles [140 km] WNW of Birdsville, Boyland 290, 25 Sep 1966 (BRI, CANB, NSW). New South Wales: Amphi Sandhills, $13 \mathrm{~km}$ SE of Menindee, towards Ivanhoe, Sikkes 342 \& Ollerenshaw, 29 Oct 1972 (AD, K, MEL, NSW).

\section{S. galegifolia (Andr.) R. Br.}

(Brown in W.T. Aiton 1812: 327)

BASTONYM: Vicia galegifolia Andr. (H.C. Andrews 1803: t. 319); Colutea galegifolia (Andr.) Sims (J. Sims 1804: t. 792); S. coronillifolia var. galegifolia (Andr.) Maiden \& Betche (J.H. Maiden \& E. Betche 1916: 107).

TYPE: the plate (Andrews 1803: t. 319).

S. galegifolia var. coccinea Lindl. (J. Lindley 1826: t. 994). A superfluous name based on V. galegifolia Andr.

S. coronillifolia Salisb. (W. Hooker \& R.A. Salisbury 1806: t. 28); S. galegifolia var. coronillifolia (Salisb.) Moore \& Betche (C. Moore \& E. Betche 1893: 150) non Bailey (1883); Colutea coronillifolia (Salisb.) Dum.-Cours. (G.L.M. Dumont de Courset 1814: 321). TYPE: t. 28

S. galegifolia var. albiflora Lindl. (J. Lindley 1826: t. 994); S. albiflora (Lindl.) G. Don (G. Don 1832: 245) non Lodd. (C. Loddiges 1830). TYPE: t. 994.

S. albiflora Lodd. (C. Loddiges 1830: t. 1642); S. coronillifolia var. albiflora (Lodd.) Maiden \& Betche (J.H. Maiden \& E. Betche 1916: 107), referring both to Loddiges and Lindley, as does Bentham. TYPE: t. 1642.

S. osbornii T. Moore (in A. Henfry, T. Moore \& W.P. Ayres 1852: t. 65); S. coronillifolia Salisb. var. purpurea Regel (E.A. von Regel 1887: 108). Based on S. osbornii Moore. TYPE: t. 65.

S. ferrandii Hort. (1863). Publication not seen.

S. galegifolia var. alba Henderson \& A. Henderson, (E.G. \& A. Henderson 1864: t. 69) without illustration or cited specimen.

S. magnifica Dombr. (H.H. Dombrain 1866: t. 273). TYPE: probably the plate.

S. coronillifolia var. alboviolacea Regel, l.c. TYpe: not designated.

S. galegifolia var. coronillifolia Bailey (F.M. Bailey 1883: 106); S. galegifolia forma coronillifolia (Bailey) Domin (K. Domin 1926: 206). No other author or type specimen cited.

S. galegifolia var. albiflora Bailey (F.M. Bailey 1883: 106) non Lindl.; S. galegifolia forma 
albiflora (Bailey) Domin (K. Domin 1926: 207). No other author or type specimen cited. S. ferrandii var. alba Carrière (E.A. Carrière 1886: 562). TYPE: not designated.

S. atrococcinea Carrière (E.A. Carrière 1887: 275). TYPE: not designated.

S. galegifolia var. albiflora C. Moore \& Betche (C. Moore \& E. Betche 1893: 150) non Lindl. TYPE: not designated.

S. ferrandii var. carminia Hort. ex Hubb. (Hubbard in L. Bailey 1902: 1751). Type: not designated.

S. ferrandii var. alba Hort. ex Hubb., 1.c., non Carrière. TYPE: not designated.

S. alba Hort. ex Hubb., l.c. Type: not designated.

S. galegifolia var. rosea Hort. ex Hubb., 1.c. TYPE: not designated.

S. galegifolia var. violacea Hort. ex Hubb., 1.c. TYPE: not designated.

S. galegifolia var. cooperi Guilfoyle (W.R. Guilfoyle 1909: 345). TYPE: not designated.

S. galegifolia var. alba Guilfoyle, l.c., non Henderson \& A. Henderson (1864). TYPE: not designated.

S. galegifolia var. microphylla Guilfoyle, l.c. TYPE: not designated.

S. galegifolia var. osbornii Guilfoyle, 1.c. TYPE: not designated.

S. galegifolia var. pallida Guilfoyle, 1.c. TYPE: not designated.

S. galegifolia var. robusta Guilfoyle, l.c. TYPE: not designated.

S. galegifolia var. robusta-rosea Guilfoyle, l.c. TYPE: not designated.

S. galegifolia var. rosea Guilfoyle, 1.c., non Hubb. (Hubbard in Bailey 1902). TYPE: not designated.

A subshrubby perennial, usually with several main stems, up to $1 \mathrm{~m}$ or more high, frequently rhizomatous. Stems usually 2-3 but occasionally to $5 \mathrm{~mm}$ wide, terete and somewhat ribbed, occasionally angled below the nodes, glabrous. Leaves usually 5-10 $\mathrm{mm}$ long, with c. 21-29 leaflets above a short petiole, the leaflets often narrowly obovate to elliptic, glabrous, the lower mostly 8-15 $\mathrm{mm}$ long and 3-5 mm wide, the terminal varying in size when compared with the shorter upper laterals, the leafletapex rounded to emarginate, often with a small point. Stipules (Fig. 1) 2-5 mm long, deltoid, sometimes acuminate, green or scarious, joined across the back to form an abaxial ridge and often with a few marginal hairs. Racemes mostly $10-20 \mathrm{~cm}$ long but variable in length, with 15-20 flowers of uneven age. Peduncle c. 1-1.5 mm wide, without a pulvinus, with flowers in the upper $2 / 3$, ribbed, glabrous. Bracts ovate, 1 c. $3 \mathrm{~mm}$ long. Flowers very variable in colour, the colour often regional, from white, pink and purple to yellow, orange and dark red, often c. $15 \mathrm{~mm}$ long, on glabrous pedicels 5-10 mm long. Hypanthium (Fig. 2) rather narrow-based, contracting at the apex under the fruiting calyx, the bracteoles small and long-deltoid. Calyx (Fig. 2) with the tube c. 2-3 $\mathrm{mm}$ long, obviously and obliquely expanding above the hypanthium, glabrous, the lobes deltoid, often shortly, and acuminate, often much shorter than the tube, the upper shortest, the sinuses usually broad and shallow. Standard (Fig. 3) to $15 \mathrm{~mm}$ long and as wide or wider, rounded at the base above an inset short tapered claw, with two plate-like calli in the lower part. Wings to c. $8 \mathrm{~mm}$ long, variably curved-deltoid-oblong, narrowly obtuse, the claw short, tapering and somewhat curved, the auricle rather deep and deltoid. Keel (Fig. 5) 10-15 mm long and 5$6 \mathrm{~mm}$ deep, with the apex somewhat narrowly obtuse and obscurely lipped, with the 
upper margin almost straight, and with folds near the base, the claw short and tapering, the auricles rather deep and rounded. Ovary 4-7 mm long, narrowly elliptic, curved, glabrous, the apex gradually contracting to a rather broad style-base, the base also tapering. Ovules numerous. Stipe $2-3 \mathrm{~mm}$ long, slender, glabrous. Style slender beyond the base, thin-textured, laterally compressed, tapering in the lower part then scarcely to a slender straight or slightly incurved tip, sometimes with a few hairs, not twisted, the curvature mostly in the lower part, the beard fine, long and even, and over most of the length. Fruit usually $20-40 \mathrm{~mm}$ long and 15-25 mm wide, elliptic, a little inflated, with the suture not intruded, gradually or shortly tapered, usually to an attenuate base, above a stipe often more than $10 \mathrm{~mm}$ long, and at the apex to a stiff straight or upturned beak below a recurved c. $8 \mathrm{~mm}$ style or its remains, pendulous, spreading or even erect at maturity, readily dehiscent at least along the suture, glabrous, the texture stiff and becoming coriaceous or even rather woody, the veins delicate, at c. $90^{\circ}$, the tissue absent.

In coastal areas and on the dividing range from tropical Queensland to northern Victoria, extending inland to the plains especially in New South Wales. In both light and heavy soils, in a variety of habitats from grassland and dry sclerophyll woodland to rainforest margins. Fig. 8.

Selected SPecimens (from c. 400 examined): QueEnsLand: Amys Peak, Croombit Tableland, c. 60 km SW of Gladstone, Crisp 2840, 5 June 1977 (BRI, CBG, NSW). New South Wales: Mt Kaputar, Jackson 2248, 30 Oct 1972 (AD, BRI, MEL, NSW); 3 miles [5 km] N of Wallabadah, Goode 109, 11 Nov 1954 (BM, NSW); Batemans Bay, Boorman, June 1906 (NSW). ViCTORIA: Kookaburra road, 13 km ESE of Barnawartha, Kirkwood, 20 Nov 1984 (CANB, MEL, NSW).

\section{S. sejuncta J. Thompson, sp. nov.}

Herba fruticosa perennis usque ad c. $1 \mathrm{~m}$ alta. Foliola 19-31, obovato-elliptica. Racemi plerumque $10-15 \mathrm{~cm}$ longi, floribus $15-20 \mathrm{~mm}$ longis. Calyx lobis longi-acuminatis vel aristatis tubo longioribus. Vexillum versus basim callis duobus. Carina obtusa. Stylus angustatus apice subinflexo. Fructus c. $30 \mathrm{~mm}$ longus, c. $15 \mathrm{~mm}$ latus, late ellipticus sutura non intrusa.

TyPe: QueEnsland: Consuelo Tableland, Carnarvon Gorge National Park, D.F. Blaxell $1535 \mathcal{E}$ J. Armstrong, 2 Sep 1977; holo NSW; iso BRI, K.

A several-stemmed subshrubby perennial to $c .1 \mathrm{~m}$ high, the base of the plant not seen. Stems usually $2-3 \mathrm{~mm}$ wide, somewhat angled with strong ribs from the nodes, glabrous. Leaves 5-10(-15) cm long, with 19-31 leaflets above a very short petiole, the leaflets obovate-elliptic to almost narrow-ovate, glabrous, the lower mostly 10-15 mm long and 3-5 $\mathrm{mm}$ wide, the terminal variable in relation to the shorter upper laterals, the leaflet-apex slightly to deeply emarginate, with a small point. Stipules c. $3 \mathrm{~mm}$ long, with scarious margins, joined to form an abaxial ridge and virtually glabrous. Racemes mostly $10-15 \mathrm{~cm}$ long, often with 5-10 flowers rather dissimilar in age. Peduncle (0.5-)1-1.5 mm wide, with a pulvinus, with flowers in the upper $1 / 2$ to $2 / 3$ of its length, ribbed, with sparse short very fine irregular hairs, more dense in the upper part. Bracts, narrow, 2-10 mm long. Flowers yellow and partly brown or orange, or white and partly pink or pink, 15-20 mm long, on puberulous pedicels to $5 \mathrm{~mm}$ long but often shorter. Hypanthium very short and broad, somewhat contracting at the apex under the fruiting calyx, the bracteoles sometimes elongated and narrow, but usually c. $1 \mathrm{~mm}$ or less long. Calyx with the tube 2-2.5 $\mathrm{mm}$ long very broadly and somewhat obliquely expanded above the hypanthium, glabrous or puberulous at the base, the lobes long-deltoid, all long-acuminate to aristate, often almost twice the length of the tube, rather uneven, the sinuses broad and rounded 
though often only narrowly so. Standard 15 to $20 \mathrm{~mm}$ long and often much wider than long, i.e. often $20-25 \mathrm{~mm}$ wide, rounded at the base above a rather inset shorttapered claw, with two plate-like calli near the base. Wings very variable, $7-15 \mathrm{~mm}$ long, deltoid to oblong and curved, the apex from narrowly obtuse to broadly expanded, the claw rather long, slender and curved, the auricle deep and rounded, often almost truncate. Keel 10-c. $20 \mathrm{~mm}$ long and 6-10 $\mathrm{mm}$ deep, with the apex broadly to narrowly obtuse with the tip sometimes conspicuously lipped, with the upper margin straight or with a slight curve, upward or downward, near the tip, and without obvious folds at the base, the claw rather long and slender with little taper, the auricles rounded to truncate and of moderate depth. Ovary c. $6 \mathrm{~mm}$ long, narrowly ovoid-elliptic, glabrous or with some hairs continuing from the beard, the apex tapering to the broad style-base, the base tapering more suddenly and rather oblique. Ovules numerous. Stipe c. $1.5 \mathrm{~mm}$ long, rather stout, glabrous. Style slender above its base, thin-textured, laterally compressed, tapering at the base and then much more gradually to the narrow, slightly inflexed, tip, without a tuft of hairs, not twisted, the curvature slight and least in the central area, the beard fine, of moderate length, and over the whole length. Fruit c. $30 \mathrm{~mm}$ long and $15 \mathrm{~mm}$ wide, broadly elliptic, much inflated, with the suture not intruded, at the base abruptly tapering, with a narrow tapered region merging into the $1-3 \mathrm{~mm}$ stipe, at the apex abruptly tapering behind a stiff, obliquely placed, beak below the recurved c. $10 \mathrm{~mm}$ style or its remains, at maturity pendulous or lifting above the horizontal, dehiscent along the suture, glabrous, the texture stiffly membranous at first but soon becoming very firm so as to appear woody, the veins delicate but conspicuous, at $90^{\circ}$, the tissue absent.

Limited to the Carnarvon Range area of Queensland. In sandy, clay-loam or basalt soils in eucalypt forest. Fig. 8.

This species is named for its distinct distribution within the group. From the Latin sejunctus, isolated.

Selected SPECIMENS (from 9 examined): QueEnSLAnd: Consuelo Tableland, c. $80 \mathrm{~km}$ SW of Rolleston, Crisp 3051, 15 June 1977 (BRI, CBG); Arch Creek, 'Early Storms', Gittins 2766, 10 Sep 1974 (BRI, NSW); Carnarvon Creek, Carnarvon Ranges, May 3 (BRI); Carnarvon Creek National Park, Gittins 352, Aug 1961 (BRI); Carnarvon Gorge, Johnson 2392, 26 May 1962 (BRI).

\section{S. queenslandica J. Thompson}

\section{(J. Thompson 1990: 1)}

Type: New South Wales: North Western Plains: $9 \mathrm{~km} \mathrm{~W}$ of 'Gunyerwarildi' on the Crooble road, K.L. Wilson 2481, 28 Nov 1982; holo NSW; iso BRI, K, L, MO, RSA.

A subshrubby perennial to $1 \mathrm{~m}$ or more high, usually several-stemmed and perhaps rhizomatous. Stems usually 3-5 mm or even more in width, terete or somewhat angled with ribs below the nodes, glabrous or with sparse, extremely fine, flat, pointed, irregularly spreading, crisped, basifixed hairs, mostly $0.5 \mathrm{~mm}$ or less long. Leaves from less than 5 to c. $10 \mathrm{~mm}$ long, with c. 19-25 leaflets above a short petiole, the leaflets occasionally ovate, usually very narrow-ovate, glabrous or almost so, the lower mostly $10-20 \mathrm{~mm}$ long and $2-3(-7) \mathrm{mm}$ wide, the terminal usually similar to the very short upper laterals, the leaflet-apex rounded to emarginate, often with a small point. Stipules to c. $3 \mathrm{~mm}$ long, deltoid or long-deltoid, acuminate, green or scarious, joined to form an abaxial ridge, and glabrous. Racemes mostly $15-20 \mathrm{~cm}$ or more long, often with c. 20 flowers of uneven age. Peduncle 1-2 mm wide, without a pulvinus, with flowers occupying $1 / 2$ (or occasionally more or less) of the length, ribbed, sometimes very conspicuously, glabrous or, more usually, with fine crisped 
hairs. Bracts ovate, 1-c. $2 \mathrm{~mm}$ long. Flowers of various colours, white, pink or purplish pink to orange-red or dark red, mostly c. $15 \mathrm{~mm}$ long, on minutely puberulous pedicels to c. $5 \mathrm{~mm}$ long but often much shorter especially on the upper part of the peduncle. Hypanthium short and broad but tending to contract at the top under the fruiting calyx, the bracteoles small, ovate-deltoid. Caly $x$ with the tube c. $2-3 \mathrm{~mm}$ long, broadly and obliquely expanded above the hypanthium, with minute hairs or occasionally glabrous, the lobes deltoid, obtuse to very shortly acuminate, much shorter than the tube, the upper shorter and broader than the lower, the sinuses broad and shallow or deeper, mostly almost deltoid. Standard c. $15 \mathrm{~mm}$ long and as wide or wider, rounded at the base above a slightly inset tapered claw, with two large platelike calli near the base. Wings often 10 to $15 \mathrm{~mm}$ long, mostly oblong or with the apex broader, usually shortly obtuse, the claw very short, tapering and somewhat curved, the auricle rounded and not large. Keel 10-15 $\mathrm{mm}$ long and 4-5 mm deep, with the apex rather narrowly obtuse and obscurely lipped, with the upper margin almost straight or a little curved, and without obvious folds near the base, the claw short, rather stout and tapered, the auricles rounded but not deep. Ovary c. 4-8 mm long, obliquely oblong, glabrous, with some hairs near the base or densely partly or wholly pubescent, the apex a little tapering to a rather broad style-base, the base obliquely and shortly tapering. Ovules numerous. Stipe 1-1.5 mm long, stout, glabrous. Style slender beyond the base, thin-textured, somewhat laterally compressed, tapering at the base then more gradually above to a straight slender tip, without a tuft of hairs, not twisted, the curvature mostly in the lower part, the beard fine, of moderate length, even, and over most of the length. Fruit $25-40 \mathrm{~mm}$ long and c. $15 \mathrm{~mm}$ wide, usually broadly elliptic, much inflated, with the suture not intruded, at the base almost rounded above a very short, tapered, narrow section that usually merges into a stipe $5-10 \mathrm{~mm}$ long, at the apex almost rounded behind a short straight beak below a recurved style of c. $5 \mathrm{~mm}$ or its stout base, pendulous or tending to lift at maturity, readily dehiscent along the suture, glabrous or with an almost imperceptible very fine pubescence, the texture membranous or so stiff as to appear woody, the veins rather delicate or conspicuous, at c. $90^{\circ}$, the tissue very short but evident.

In inland areas of north-eastern New South Wales and coastal and inland parts of central and south-eastern Queensland. In open forest on a variety of soils from red sandy loam to heavy black clay. Fig. 8.

SELECTED SPECIMENS (from c. 160 examined): QueENSLAND: 29 miles [46 km] WSW of Rolleston Township, Lazarides \& Story 28, 31 Aug 1961 (AD, BRI, CANB, K, MEL, NSW, NT); $20 \mathrm{~km} \mathrm{~N}$ of Gayndah, Woolcock 415, 23 Aug 1983 (AD); Warrego Highway between Oakey \& Dalby, Moriarty 860, Dec 1971 (BRI, CANB, K). NEW SOUTH WALEs: 24 miles [40 km] NE of Inverell towards Emmaville, Coveny 2275, 4 Oct 1969 (BRI, NSW, NT); 10.5 km NW of Mt Russell, on Gunnee road, Jacobs, Wilson \& Lapinpuro LL32, 27 Nov 1982 (BRI, K, NSW).

\section{S. bracteata (Maiden \& Betche) J. Thompson}

\section{(J. Thompson 1990: 1)}

BASIONYM: S. greyana var. bracteata Maiden \& Betche (J.H. Maiden \& E. Betche 1903: 905); S. greyana subsp. bracteata (Maiden \& Betche) A. Lee (A.T. Lee 1948: 158).

TYPe: New South Wales: Central Western Slopes: between Gilgandra and Gummin, W. Forsyth NSW 368, Oct 1901; holo NSW.

A subshrubby perennial $50 \mathrm{~cm}$ to $1 \mathrm{~m}$ or more high with a number of stems from a woody taproot, and, at least sometimes, with rhizomes deep underground. Stems often 3-4(-5) $\mathrm{mm}$ wide, terete, or somewhat ribbed or even angled below the nodes, pubescent with extremely fine, pointed, dense or sparse, crisped, flat, basifixed, spread- 
ing hairs, c. $0.5 \mathrm{~mm}$ long. Leaves usually 5-10 cm long, with c. 19-25 leaflets above a short petiole, the leaflets mostly narrowly ovate, glabrous or with sparse or dense crisped hairs almost restricted to the lower surface, the lower usually c. $15 \mathrm{~mm}$ long and 5-7 $\mathrm{mm}$ wide, the terminal longer or shorter than the shorter upper laterals, the leaflet-apex rounded to emarginate, often with a small point. Stipules usually $2-5 \mathrm{~mm}$ long, deltoid to long-deltoid, often obliquely so, obtuse to long-acuminate, green or scarious, joined across the back to form an abaxial ridge and pubescent only on the outer surface. Racemes mostly 15-20 cm long, often with 20 or more flowers of uneven age. Peduncle usually 1-2 mm wide, without a pulvinus, with flowers in the upper $1 / 2$, ribbed, often conspicuously, and usually with a rather sparse pubescence of fine, irregular hairs. Bracts long-ovate-lanceolate and leafy, often $8-10 \mathrm{~mm}$ long. Flowers white, pale pink or pale purple, 15-20 mm long, on pubescent pedicels 3 or $4 \mathrm{~mm}$ long. Hypanthium short and tending to contract at the apex under the fruiting calyx, the bracteoles large and similar to the bracts. Calyx with the tube c. $4 \mathrm{~mm}$ long, obliquely and conspicuously expanded above the hypanthium, with tangled dense to sparse fine crisped hairs, the lobes deltoid to long-deltoid, often short but usually variously and unequally long-acuminate, to about equal to the tube, the sinuses mostly broad and rounded. Standard $15-20 \mathrm{~mm}$ long and as wide or a little wider, with the base rounded above an inset short tapered claw, and with two plate-like calli in the lower part. Wings variable, often c. $8 \mathrm{~mm}$ long, and curved-deltoid to oblong, usually narrowly obtuse, the claw rather short and narrow and curved, the auricle deep and rounded. Keel often $15 \mathrm{~mm}$ long and $5 \mathrm{~mm}$ deep, with the apex narrowly obtuse, with the upper margin straight, and with obscure folds or pockets near the base, the claw rather short and curved but without much taper, the auricles variable. Ovary c. 6-9 mm long, narrowly elliptic, glabrous or with some hairs at the base, the apex tapering to a rather broad style-base, the base also tapering. Ovules numerous. Stipe 2-3 mm long, slender, glabrous or with some pubescence. Style slender, thin-textured, somewhat laterally compressed, evenly tapered to a slender straight or somewhat incurved tip, without a tuft of hairs, not twisted, curved mostly in the lower part, the beard fine, long and even, and over most of the length. Fruit usually 40-50 mm long and 10-20 mm wide, elliptic, often broadly so, a little inflated, with the suture not intruded, variably tapered to, or even rounded above, a short, narrow, tapered base above a stipe at least $5 \mathrm{~mm}$ long and at the apex to a short, tapered, straight or upturned beak below a recurved style c. $4 \mathrm{~mm}$ long or its remains, pendulous or raised at maturity, dehiscent, but not always readily so, along the suture, glabrous (except sometimes at the base), the texture stiff and brittle, the veins visible but not much raised, at $90^{\circ}$, the tissue absent.

Mainly on the western slopes of the dividing range in New South Wales and in inland southern Queensland. Usually associated with light soils and eucalypt and Callitris woodland. Fig. 9.

Selected sPecimens (from c. 65 examined): QueEnSLAND: Moreton Bay, Mueller, 1863 (NSW, ?dupl CANB). New South WALEs: Moree, Cleland, 25 Oct 1917 (AD); Warrumbungles-Tooraweenah road, Streimann 517, 4 Dec 1973 (AD, CBG, NSW); Gilgandra, Penfold, Dec 1927 (NSW).

8. S. cadellii (as 'cadelli') F. Muell. ex C. Moore \& E. Betche

(C. Moore \& E. Betche 1893: 150)

S. greyana subsp. cadellii (F. Muell. ex C. Moore \& E. Betche) A. Lee

(A.T. Lee 1948: 159)

TYPE: NeW SOUTH WaLEs: North Western Slopes: Warrumbungle Ranges, E. Betche 143, Jan 1883; lecto (fide Lee 1948: 159) MEL; probable iso MEL, NSW. 
A subshrubby perennial to c. $1 \mathrm{~m}$ high, with a number of stems and, probably, a taproot. Stems often 3-5 mm wide, terete or somewhat angled, and often with ribs extending from the nodes, glabrous or sparsely pubescent with extremely fine, pointed, crisped, flat, spreading, basifixed hairs often c. $0.5 \mathrm{~mm}$ long but with some shorter or longer than this. Leaves 5-15 cm long, with c. 15-25 leaflets above a short petiole, the leaflets mostly narrowly ovate, glabrous or with sparse spreading fine crisped hairs on the lower surface, the lower mostly $10-20 \mathrm{~mm}$ long and 3-6 mm wide, the terminal variable in relation to the short upper laterals, the leaflet-apex rounded to emarginate, often with a small point. Stipules $2-c .5 \mathrm{~mm}$ long, the longer lanceolateacuminate, green or scarious, joined to form an abaxial ridge and glabrous or pubescent on the outer surface. Racemes often 20 to more than $25 \mathrm{~cm}$ long, with 15-20 flowers of uneven age. Peduncle 1-2 mm wide, without a pulvinus, with flowers on the upper $1 / 2$ or a little less, ribbed, usually with a pubescence of irregular fine hairs at least in the upper part. Bracts leafy, narrow-lanceolate, acuminate or even aristate, often over $10 \mathrm{~mm}$ long. Flowers white, pink or purple, $15-20 \mathrm{~mm}$ long, on pubescent pedicels of $5 \mathrm{~mm}$ or occasionally more. Hypanthium often rather slender in the lower part and not contracting significantly under the fruiting calyx, the bracteoles long and similar to the bracts. Calyx with the tube c. $3 \mathrm{~mm}$ long, widely and somewhat obliquely expanded above the hypanthium, with a very short crisped pubescence, the lobes deltoid at the base, with long aristate tips, especially long on the lower lobes, so that they are often twice as long as the tube, the sinuses usually broadly rounded. Standard 12-20 mm long and as broad, with the base rounded above a short tapered claw, and with two plate-like calli near the base. Wings often c. $10 \mathrm{~mm}$ long, oblong to subdeltoid, somewhat curved, the apex broadly or narrowly obtuse, the claw variable in length, tapering and curved, the auricle deltoid and deep. Keel often c. $15 \mathrm{~mm}$ long and 4-5 $\mathrm{mm}$ deep, with the apex narrowly obtuse to acute, with the upper margin straight or slightly curved so as to raise the apex, and with conspicuous or obscure swellings in the lower part, the claw rather long and slightly tapered and curved, the auricles variably rounded or almost truncate. Ovary c. 6-8 mm long, narrowly elliptic, glabrous or with hairs along the suture, the apex tapering to a rather broad style-base, the base somewhat obliquely and shortly tapered. Ovules numerous. Stipe 1.5-3 mm long, slender, glabrous or pubescent on the sutural side. Style slender, thin-textured, somewhat laterally compressed, evenly but not strongly curved, not twisted, evenly tapering to a slender straight or somewhat incurved tip, without a tuft of hairs, the beard fine, moderately long, even, and over the whole length. Fruit mostly 25-40 mm long and c. 10-30 mm wide, elliptic, sometimes extremely broadly so, a little inflated, with the suture not intruded, tapering, often abruptly, to a stipe of variable length and often more than $5 \mathrm{~mm}$ long, and at the apex rounded or tapering, symmetrically or obliquely, to a short beak below a recurved 4 $\mathrm{mm}$ style or its remains, spreading or raised at maturity, dehiscent along the suture, glabrous, the texture stiff and brittle, the veins delicate, at $90^{\circ}$, the tissue negligible.

Mostly in the Warrumbungle Ranges area of the North Western Slopes of New South Wales. In red sandy loam soils, in eucalypt woodland and grassland. Fig. 9.

SElected specimens (from c. 40 examined): New South WALES: Pilliga Forest between Narrabri \& Coonabarabran, Pedley 1606, 7 Nov 1963 (BRI, K); between Baradine \& Wangan, near Wangan, Cleland, 12 Oct 1918 (AD); Gunnedah-Coonabarabran, Moore 1383, 14 Sep 1950 (CANB); Tambar Springs, Althofer, Sep 1970 (NSW); Warrumbungle Ranges, Forsyth, Oct 1899 (BM, MEL, NSW, PERTH). 


\section{S. greyana Lindl.}

\section{(J. Lindley 1846: 66)}

TYPE: the plate (J. Lindley 1846: t. 66), from a cultivated plant.

S. grandifolia R. Br. (Brown in C. Sturt 1849: 74). TYPE: rich alluvial flats of the Murray and Darling, C. Sturt; holo BM.

A subshrubby, usually several-stemmed perennial up to $1.5 \mathrm{~m}$ or more high, with a taproot, and with rhizomes well beneath the soil surface. Stems often more than $5 \mathrm{~mm}$ wide, terete or somewhat angled below the nodes, pubescent with extremely fine, pointed, spreading, crisped, flat, basifixed hairs, mostly $0.5-1 \mathrm{~mm}$ long. Leaves often 10-15 cm long, with 17-21 or more leaflets above a short petiole, the leaflets mostly obovate-elliptic, with sparse or dense fine crisped hairs virtually restricted to the lower surface, the lower mostly 10-30 mm long and 5-10 mm wide, the terminal variable in relation to shorter upper laterals, the leaflet-apex broadly obtuse with a minute point. Stipules to c. $8 \mathrm{~mm}$ long, deltoid to somewhat lanceolate, narrowly obtuse to acuminate, green or scarious, joined across the back to form a ridge and usually densely pubescent, but only on the outer surface. Racemes $10-40 \mathrm{~cm}$ long, with 12 to 20 or more flowers of uneven age. Peduncle usually $1.5-3 \mathrm{~mm}$ wide, without a pulvinus, with flowers occupying $1 / 2$ to most of its length, strongly ribbed, with a very fine crisped and irregular pubescence of variable density. Bracts broadly ovate-lanceolate, usually 5-10 mm long. Flowers white, pink or purple, usually c. 20 $\mathrm{mm}$ long, on pubescent pedicels of 5-8 $\mathrm{mm}$. Hypanthium short and broad, tending to contract under the fruiting calyx, the bracteoles often linear-lanceolate and several millimetres long. Calyx with the tube 3-5 mm long, expanded obliquely but somewhat variably above the hypanthium, with a dense white-woolly pubescence, the lobes deltoid, occasionally acuminate, the upper broader, all usually much shorter than the tube, the sinuses variable but usually deltoid. Standard 15 to more than 20 $\mathrm{mm}$ long and as wide or a little wider, at the base tapering to or rounded above a short tapered claw, with two plate-like calli near the base. Wings often c. 15-21 mm long, oblong, obtuse, the claw rather long, conspicuously tapering and somewhat curved, the auricle approximately as deep, rounded and somewhat folded. Keel 15-22 $\mathrm{mm}$ long and 6-8 $\mathrm{mm}$ deep, with the apex rather narrowly obtuse and obscurely lipped, with the upper margin straight, and with obscure folds or pockets near the base, the claw quite long, slightly tapered and little curved, the auricles rounded but not very deep. Ovary c. $6-10 \mathrm{~mm}$ long, elliptic, curved, glabrous, the apex tapering to a rather broad style-base, the base long and somewhat obliquely tapered. Ovules numerous. Stipe 2-4 mm long, slender, glabrous. Style slender, thin-textured, laterally compressed, tapering, above the rather broad base, rather evenly to a fine straight or slightly inflexed tip, occasionally with a few hairs behind the tip, not twisted, the curvature not strong and only slight in the upper part, the beard fine, of moderate length and over most of the length. Fruit often more than $50 \mathrm{~mm}$ long and $25 \mathrm{~mm}$ wide, elliptic, usually broadly so, somewhat inflated, with the suture not intruded, suddenly or gradually, symmetrically or somewhat obliquely, tapered at the base to a stipe usually c. $10 \mathrm{~mm}$ long, and at the apex to a very short beak below the recurved c. $8 \mathrm{~mm}$ style or its remains, pendulous to erect at maturity, readily dehiscent along the suture, glabrous, the texture stiffly membranous, the veins delicate, at c. $90^{\circ}$, the tissue negligible.

In south-eastern South Australia, inland New South Wales and southern inland Queensland. Almost limited to the heavy grey soils of the banks and flats of the lower Murray River and the Darling River and its major tributaries. Fig. 9. 
Selected SPECimens (from c. 160 examined): South Australia: W bank of Murray River at mouth of Moorundee Creek, c. 8 miles [13 km] S of Blanchetown, Belcher \& Belcher 288, 22 Oct 1967 (MEL, NSW). QueENSLAND: Welltown, Pedley 492, 6 Oct 1959 (BRI, NSW). New SOUTH Wales: 17 km NW of Brewarrina, Paijmans 3198, 21 Aug 1979 (CANB); 6 miles [10 km] N of 'Bindara' on Menindee road, De Nardi 1074 (K, NSW). VICTORIA: Lindsay River, SE of junction with Murray River, Beauglehole 40627, 20 Oct 1972 (MEL).

\section{S. fraseri Benth.}

(G. Bentham 1864: 224)

TYPe: New South Wales: North Coast: Hastings R., Beckler; lecto (fide Lee 1948: 161) MEL; iso K, NSW.

\section{S. colutoides var. fraseri (Benth.) F. Muell. (F. Mueller 1876: 6).}

A subshrubby plant to $1.5 \mathrm{~m}$ or more high, the base of the plant not seen. Stems often $5 \mathrm{~mm}$ wide, terete or somewhat angled, often strongly ribbed, often conspicuously flexuose, with scattered, minute, flat, narrowly elliptic, pointed, appressed, sometimes loosely, and basifixed hairs. Leaves 5-10(-15) cm long, with c. 21 leaflets above a short petiole, the leaflets somewhat elliptic-oblong, with spaced appressed hairs on the lower surface, the lower 5-15 $\mathrm{mm}$ long and 3-6 $\mathrm{mm}$ wide, the terminal variable in relation to the shorter upper laterals, the leaflet-apex mostly truncate or emarginate with a minute point. Stipules to $5 \mathrm{~mm}$ long, rather leaf-like in the upper part but with the broad scarious base tending to extend down the stem a little, linear-lanceolate in the upper part, forming a distinct abaxial ridge and with hairs especially on the inner surface. Racemes usually 5-20 cm long, often with over 20 flowers of uneven age. Peduncle $0.5-2(-3) \mathrm{mm}$ wide, with a pulvinus, with flowers occupying $2 / 3$ or more of its length, ribbed or somewhat angled, with scattered, spreading or appressed, very short and irregular, flat hairs. Bracts very narrow, c. $2 \mathrm{~mm}$ long. Flowers pink-purple, $10-15 \mathrm{~mm}$ long, on densely short-pubescent pedicels usually 3-7 $\mathrm{mm}$ long. Hypanthium short or attenuated, tending to contract below the fruiting calyx, the bracteoles minute. Caly $x$ with the tube c. $2 \mathrm{~mm}$ long, not widely expanded above the hypanthium, with spaced appressed flat hairs, the lobes usually deltoid-acuminate, shorter than the tube, the upper often the shortest, the sinuses shallowly and broadly rounded. Standard c. 10-12 mm long and as broad, broadly rounded above a tapering claw, without calli but, at least sometimes, irregularly thickened near the base. Wings 7-9 $\mathrm{mm}$ long, narrowly obovoid and curved, the apex very broad and shallowly obtuse, the claw rather long, slender and curved, the auricle rather deep, and long and rounded. Keel 9-12 $\mathrm{mm}$ long and 5-6 $\mathrm{mm}$ deep, with the apex obtuse with the rather lipped tip extended or retracted, with the upper margin curved, especially towards the auricle, and with folds near the base, the claw long and slender, the auricles long, rather deep and rounded. Ovary $4-6 \mathrm{~mm}$ long, narrowly elliptic, glabrous or with occasional hairs, the apex somewhat tapering to a rather broad style-base, the base often scarcely narrowing. Ovules numerous. Stipe $2-3 \mathrm{~mm}$ long, slender, glabrous. Style slender, thin-textured, laterally compressed, with a slight even taper to a slender strongly incurved or coiled tip with a band of antrorse hairs hiding the stigma, not twisted, the curvature even or less in the central area, the beard fine, rather long, extending over the whole length but often sparsely so. Fruit c. 30-40 mm long and 10-13 $\mathrm{mm}$ wide, elliptic, variably inflated, with the suture not intruded, tapered, often obliquely, to a narrow long- tapering base above a slender stipe often c. $4 \mathrm{~mm}$ long, and at the apex more suddenly and obliquely to a straight beak behind a c. $4 \mathrm{~mm}$ recurved style or its remains, becoming erect at maturity, dehiscence not seen, perhaps indehiscent, glabrous, the texture stiffly membranous, the veins very delicate, at c. $90^{\circ}$, the tissue absent. 
In south-eastern Queensland and northern coastal New South Wales. In sheltered open forest. Fig. 9.

Selected SPECIMENS (from c. 20 examined): QueENSLAND: Bribie Island, Eaves, 1882 (MEL); $1.5 \mathrm{~km}$ S of Northbrook Mtn, Brisbane Forest Park, Young 614, Aug 1982 (BRI, NSW); Cabbage Tree Creek, Young 621, Sep 1982 (BRI, NSW). NEw South WALES: Macleay Gorges-Blue Mountain Creek, King 366, 18 Sep 1984 (NSW); Port Macquarie, Brown, Dec 1897 (MEL).

\section{S. brachycarpa Benth.}

\section{(G. Bentham 1864: 217)}

TyPe: QueEnsLand: Jimba, plains of the Condamine, L. Leichhardt (per Pemberton Hodgson); lecto (fide Lee 1948: 159) MEL; iso NSW.

A prostrate or ascending perennial rarely over $10 \mathrm{~cm}$ high, with branched stems and a taproot or an irregular stock below ground-level; sometimes rooting from nodes, with new stems arising there, and sometimes rhizomatous. Stems usually $1(-2) \mathrm{mm}$ wide but often more slender, ridged, angled or almost winged from below the nodes, glabrous or with scattered tubercles occasionally bearing minute flat or turgid, appressed or divergent, basifixed hairs. Leaves 2 to more than $10 \mathrm{~cm}$ long but occasionally reduced or absent, with 9-13 leaflets above a petiole that may be very short or up to half the rhachis-length, the leaflets ovate-elliptic to very narrowly elliptic, glabrous or with a few minute fine hairs on the margins, the lower minute to $12 \mathrm{~mm}$ long and 1-4 $\mathrm{mm}$ wide, the terminal variable in relation to the shorter upper laterals, the leaflet-apex usually distinctly emarginate and minutely pointed, occasionally acute. Stipules c. $1 \mathrm{~mm}$ long, ovate-deltoid, green, widely separated but forming an abaxial ridge, glabrous. Racemes from 1 to $20 \mathrm{~cm}$ long, with up to 12 , but usually only a few, flowers of rather uneven age. Peduncle $0.5-1.5 \mathrm{~mm}$ wide, without a pulvinus, with flowers usually only in the top few centimetres, but sometimes over much of its length, strongly ridged or even winged, with fine, flat, irregular hairs. Bracts broadly ovate, to c. $1 \mathrm{~mm}$ long. Flowers white to purple or dark red, 6-8(-10) $\mathrm{mm}$ long, on puberulous, or occasionally glabrous, pedicels of 1-2 mm. Hypanthium slender, at least at the base, somewhat contracted at the apex under the fruiting calyx, the bracteoles minute. Calyx with the tube 1.5-2.5 mm long, broadly, somewhat obliquely, expanded above the hypanthium, glabrous or with a few minute hairs, the lobes short- to long-deltoid and acute to acuminate, shorter than the tube, the upper broader, the sinuses deltoid to broadly rounded. Standard c. $10 \mathrm{~mm}$ long and as broad or a little less, at the base abruptly tapering to a short tapered claw, and with calli in the lower part. Wings 7-8 mm long, deltoid-oblong or oblong, curved, very broadly to narrowly obtuse, the claw short, tapered and curved, the auricle rather long and narrowly rounded. Keel 6-9 $\mathrm{mm}$ long and 3.5-4 $\mathrm{mm}$ deep, with the apex rounded and the tip either retracted or with a short projecting beak, with the upper margin straight or curved, and basal folds obscure or absent, the claw short, sometimes narrow, straight, the auricles rounded and variable in depth. Ovary $2-4 \mathrm{~mm}$ long, elliptic, glabrous, the apex gradually tapering to the broad style-base, the base also tapered. Ovules numerous. Stipe 1-1.5 mm long, slender, glabrous. Style slender, thin-textured, evenly tapered to behind a narrower (narrowing from the top edge) straight, incurved or strongly inflexed tip with an antrorse tuft of hairs, not twisted, the curvature variable, the beard fine and long, along the whole length or sparse in part. Fruit usually $15-30 \mathrm{~mm}$ long and 5-10 mm wide, elliptic, or occasionally lunate, variously, often much, inflated, with the suture not intruded, at the base variably tapered to a slender stipe often 2-3 mm long, at the apex long-tapered to a straight, often oblique, beak bearing the c. $3 \mathrm{~mm}$ style or its remains, pendulous or occasionally lifting, at 
maturity, dehiscent along the suture, glabrous, the texture membranous or stiff and brittle, the veins very delicate, at $90^{\circ}$, the tissue absent.

In south-eastern Queensland and north-eastern New South Wales. In grassland and woodland, often associated with rocky sites and loamy soils. Fig. 9.

SELECTED SPECIMENS (from c. 75 examined): QuEENSLAND: Bundamba, Shirley (BRI); between Westbrook \& Southbrook, Everist 30 Aug 1950 (BRI). New South WALES: Clarence River, Wilcox, 1869 (MEL); Point Lookout, New England National Park, Telford 2368, 26 Nov 1970 (CBG). VICTORIA: Halls Gap, Grampian Mountains, Tilden 931, Dec 1912 (BM, K, MEL).

\section{Group 2}

1 Stems glabrous or with minute, broad, mostly appressed hairs

2 Stems virtually glabrous; flowers dark brownish red or dark purple to almost black, c. 10 mm long

12. S. stenodonta

$2^{*}$ Stems with short, broad, flat, appressed hairs; flowers mauve to maroon, 4-7 $\mathrm{mm}$ long

13. S. complanata

$1^{*}$ Stems with fine, loose or spreading hairs $0.5-c .2 \mathrm{~mm}$ long

3 Flowers to $15 \mathrm{~mm}$ long

4 Stipules not or scarcely extended down the stem; ovary usually with a dense long pubes cence; fruit softly pubescent

5 Leaflets c. 11; stem-hairs often more than $2 \mathrm{~mm}$ long and spreading

14. S. elegantoides

$5^{*}$ Leaflets 13-17; stem-hairs c. $0.5 \mathrm{~mm}$ long and curved

15. S. forrestii

4* Stipules variously extended down the stem; ovary with fine hairs only along the suture or with a sparse pubescence all over; fruit glabrous or with a few scattered long hairs

16. S. decurrens

3* Flowers mostly $20 \mathrm{~mm}$ or more long

6 Stipules 2-3 mm long, deltoid; flowers c. $20 \mathrm{~mm}$ long

17. S. ecallosa

$6^{*}$ Stipules usually more than $10 \mathrm{~mm}$ long, broad, with an acicular apical point and often with acicular pointed lobes; flowers c. $20-30 \mathrm{~mm}$ long 18. S. maccullochiana

12. S. stenodonta F. Muell.

(F. Mueller 1879: 70)

Type: Western Australia: Sherlock and Yule Rivers, J. Forrest, 1878; holo MEL.

An erect annual with one to several stems, often $1 \mathrm{~m}$ high, and with a slender taproot. Stems rather stout, usually $3-5 \mathrm{~mm}$ wide, ribbed, terete except for short ridges below the nodes, virtually glabrous. Leaves often c. $7 \mathrm{~cm}$ long, with 7-13 leaflets above a short petiole, the leaflets narrowly linear-elliptic or oblong, glabrous or with fine short antrorse, basifixed hairs, more frequent on the lower surface, the lower leaflets 15-25 mm long and 1-3(-4) $\mathrm{mm}$ wide, the terminal sometimes longer than the occasionally shorter upper laterals, the leaflet-apex rounded to retuse, with the point stout but minute, or absent. Stipules c. $4 \mathrm{~mm}$ long, very narrowly long-deltoid, pale or 
green, separated at the back, not forming an abaxial ridge and with hairs only on the margin. Racemes from a few to $15 \mathrm{~cm}$ long, with up to 30 or more flowers of uneven age. Peduncle 0.5-1.5 mm wide, without a pulvinus, with flowers in the upper $3 / 4$, not or scarcely ribbed, glabrous or with a few, scattered, short, antrorse, basifixed hairs. Bracts narrow, linear-deltoid, c. $1 \mathrm{~mm}$ long. Flowers from dark brownish red to dark purple, sometimes almost black, c. $10 \mathrm{~mm}$ long or a little less, on pedicels c. 3 mm long with short loosely appressed hairs at least at the base. Hypanthium short and narrow, contracted at the apex under the fruiting calyx, the bracteoles minute and deltoid or $1 \mathrm{~mm}$ long and like the bracts. Calyx with the tube 2-3 $\mathrm{mm}$ long, much and obliquely expanded above the hypanthium, glabrous or almost so or with an appressed pubescence, the lobes long-deltoid and almost equal to or less than the tube, the upper a little shorter, the sinuses narrowly rounded. Standard c. $10 \mathrm{~mm}$ long and 6-7 mm wide, tapering to a long slender tapered claw, without any thickening near the base. Wings c. $8 \mathrm{~mm}$ long, oblong, the apex sometimes broader and broadly rounded, the claw long and rather narrow, the auricle rounded and somewhat extended. Keel usually 8-10 $\mathrm{mm}$ long and 2-3 mm deep, with the apex tapering, the tip sometimes somewhat lipped, with the upper margin shallowly curved, and with slight swellings at the base, the claw long and narrow, with little taper, the auricles rather short and rounded. Ovary 2.5-4 mm long, elliptic, glabrous except for antrorse appressed hairs along the suture, occasionally the hairs more widespread but sparse, the apex rather suddenly tapering to a slender style-base, the base tapering obliquely. Ovules perhaps not exceeding 12. Stipe 1-2 mm long, very slender, glabrous. Style very slender, thin-textured, somewhat flattened in the tapered upper $1 / 3$ to a very slender straight tip, without hairs behind the stigma or with a short tuft of antrorse hairs well below it, not twisted, the curvature strong near the base, slight near the apex, the beard dense and long, in the upper 2/3. Fruit mostly 10-12 mm long and about half as wide, variably lunate, laterally compressed and only rarely inflated, with the suture not intruded, abruptly and obliquely tapering at the base to the slender c. $3 \mathrm{~mm}$ stipe and more gradually and obliquely at the apex where slightly upturned below the strongly recurved $5 \mathrm{~mm}$ style, spreading or upturned at maturity, dehiscent at the centre of the suture, glabrous or with minute appressed hairs mostly on the suture, the texture thin and papery, the veins very fine, at c. $60^{\circ}-90^{\circ}$, the tissue firm, central at the base of the funicles, or absent.

In the Pilbara region of Western Australia. Usually in light soil, in watercourses or among Triodia. Fig. 10.

Selected specimens (from 18 examined): Western Australia: Hamersley railway line between Dampier \& Mt Tom Price, Smith, Oct 1968 (PERTH); $37 \mathrm{~km} \mathrm{~S}$ of Marble Bar on the Pilga road, Norris 897, 17 Sep 1982 (MEL, NSW, PERTH); Tambrey Station, Sherlock River, Gardner 3113, 22 Aug 1932 (K, PERTH); 9 miles [14 km] E of Wittenoom, Beauglehole 11548, 16 Aug 1965 (MEL, NSW); 47 km N of Roy Hill, Demarz 8386, 21 Oct 1980 (PERTH).

\section{S. complanata J. Thompson, sp. nov.}

Herba erecta annua usque ad c. $1 \mathrm{~m}$ alta. Foliola usque ad c. 13, plerumque anguste ovata. Racemi 5-10 cm longi, floribus confertis 4-7 mm longis. Calyx lobis tubo brevioribus. Vexillum versus basim non incrassatum. Carina acuta. Stylus tenuissimus apice incurvo pilis rectis. Fructus $10-13 \mathrm{~mm}$ longus, $6-9 \mathrm{~mm}$ latus, perlate ellipticus complanatus.

TyPE: WeSTERn Australia: Track to Towera, Wielbong paddock, R.J. Cranfield 1779, 6 Aug 1981; holo PERTH.

An erect annual, probably single-stemmed, to $1 \mathrm{~m}$ high but sometimes flowering 
when a few centimetres high; with a slender taproot. Stems rather stout, usually 3-5 $\mathrm{mm}$ wide, usually strongly ribbed, terete or somewhat angled from the nodes, with short hairs, mostly on younger stems, the hairs broad, very flat or turgid, antrorse, basifixed, usually appressed and mostly $0.5 \mathrm{~mm}$ or less long. Leaves to $\mathrm{c.} 7 \mathrm{~cm}$ long, with up to $c$. 13 leaflets above a very short petiole, the leaflets in general narrowly obovate, with pubescence as for the stem but sparse on or absent from the upper surface, the leaflets to $c .15 \mathrm{~mm}$ long and (1-)3-5 $\mathrm{mm}$ wide, almost uniform, the leaflet-apex strongly retuse or emarginate with a minute point. Stipules c. $3 \mathrm{~mm}$ long, very narrowly linear, occasionally absent, green or scarious, well separated at the back where the petiole forms a joint, and with a few hairs. Racemes 5-10 cm long, with up to 20 densely packed flowers of uneven age. Peduncle $0.5-1 \mathrm{~mm}$ wide, without a pulvinus, with flowers on the upper $3 / 4$, ribbed or somewhat angled, the pubescence as for the stem but more sparse and often less appressed. Bracts linear, c. $1 \mathrm{~mm}$ long. Flowers mauve to maroon, 4-7 $\mathrm{mm}$ long, on pedicels $1.5-2.5 \mathrm{~mm}$ long, with hairs as on the stem. Hypanthium rather broad, often contracting at the apex under the fruiting calyx, the bracteoles small and linear. Calyx with the tube c. $15 \mathrm{~mm}$ long, slightly and obliquely expanding above the hypanthium, pubescent, the lobes deltoid with the upper much shorter and broader, all shorter than the tube, the sinuses very broad and rounded. Standard to c. $7 \mathrm{~mm}$ long and a little narrower, gradually tapering to the base or very slightly clawed, without any thickening. Wings c. $6 \mathrm{~mm}$ long, oblong with a rounded apex, the claw long, slender, rather curved above and tapering to the base, the auricle large, extending and rounded. Keel to c. $7 \mathrm{~mm}$ long and $2.5 \mathrm{~mm}$ deep, with the apex narrowing and acute, with the upper margin conspicuously curved, and with basal swellings absent, the claw of moderate length, rather slender and tapering, the auricles large and rounded. Ovary c. $3 \mathrm{~mm}$ long, elliptic, with a short pubescence of flat, mostly appressed hairs, sometimes sparse on the sides, shortly and obliquely tapering at the apex to a slender style-base, the base also oblique but more suddenly tapering. Ovules 2 or 3 . Stipe less than $1 \mathrm{~mm}$ long, rather slender, somewhat curved, glabrous. Style very slender, a little flattened, thin in texture, tapering little, the tip shortly incurved with a tuft of erect hairs close behind it, not twisted, the curvature even, sometimes quite strong, the beard very sparse or absent. Fruit 10-13 mm long and 6-9 mm wide, very broadly elliptic, laterally compressed with no inflation or indenting of the suture, rounded above the slender, 1 $\mathrm{mm}$ stipe and at the apex, below the c. $2.5 \mathrm{~mm}$ recurved style, pendulous or spreading at maturity, dehiscing readily along the suture, with an even, very short, appressed pubescence, the texture softly or stiffly membranous, the veins visible, usually between $60^{\circ}$ and $90^{\circ}$, the tissue absent.

In north-western Western Australia. In open loamy or stony Triodia grassland. Fig. 10.

This species is named for the strongly laterally compressed flat fruits. From the Latin complanatus, flattened.

SPeCIMENS EXAMINED: Western Australia: 6.6 miles [10 km] N of Learmonth airfield, George 10337, 8 Sep 1970 (PERTH); $51 \mathrm{~km} \mathrm{~S}$ of Woodstock turnoff, Demarz 10341, 1 Oct 1984 (PERTH); c. 110 $\mathrm{km}$ from Nanutarra, Ashby 4112, 3 Aug 1971 (AD); rockhole, Mybong, Barlee Range, Robinson, 13 Sep 1959 (PERTH).

14. S. elegantoides (A. Lee) J. Thompson, comb. nov.

Basionym: S. beasleyana subsp. elegantoides A. Lee, Contr. New South Wales Natl. Herb. 1(4):191 (1948).

TyPe: Western Australia: Upper Murchison R. near Mt Hale, Crossland (1), 1884; holo MEL. 
An erect, 1-several-stemmed plant, probably annual, to more than $1 \mathrm{~m}$ high, with a short taproot. Stems stout, often c. $5 \mathrm{~mm}$ or more in width but slender in young plants, variably ribbed or angled near the nodes, the hairs rather dense, of variable length, often more than $2 \mathrm{~mm}$ long, extremely fine, long-tapering to a fine tip, spreading and basifixed. Leaves mostly 5-10 cm long, with c. 11 leaflets above a usually short but occasionally long petiole, leaflets usually narrowly obovate, with long, spreading hairs on both surfaces, but often sparse on the upper, the lower leaflets $10-25 \mathrm{~mm}$ long and 3-8 $\mathrm{mm}$ wide, the terminal usually a little longer than the sometimes smaller upper laterals, the leaflet-apex rounded or acute, with a short acute, sometimes stiff, point. Stipules to c. $10 \mathrm{~mm}$ long, variable in size and shape, often varying with the position on the plant, usually broadly ovate with a long filiform terminal point and occasionally with lateral teeth, the base broad and often rather oblique; mostly green, usually close at the back where often, but not always, there is an obscure ridge, and pubescent on both sides. Racemes 15 to more than $30 \mathrm{~mm}$ long, with 15 to c. 25 flowers of uneven age. Peduncle 1-2(-3) $\mathrm{mm}$ wide, without a pulvinus, with flowers occupying $1 / 2$ to $3 / 4$ of its length, ribbed and with a pubescence of long fine spreading hairs. Bracts ovate-lanceolate below a long narrow tip, c. $4 \mathrm{~mm}$ long. Flowers purple, mostly 10-15 mm long, on pubescent pedicels 3-4 mm long. Hypanthium often rather narrow at least at the base, and tending to contract at the apex under the fruiting calyx, the bracteoles small (c. $1 \mathrm{~mm}$ ) and very narrowly linear. Calyx with the tube c. $2 \mathrm{~mm}$ long, obliquely and only gradually expanding above the hypanthium, with a very long fine spreading pubescence, the lobes shortly narrowing and very long-acuminate, about twice as long as the tube, the upper a little shorter and broader, the sinuses broadly rounded. Standard c. 10-15 mm long and as wide or a little less, tapering to the base or to a short claw, in the lower part with two ridges almost encircling a concave area. Wings c. $7-11 \mathrm{~mm}$ long, oblong or somewhat narrower in the centre, the apex of thin texture, somewhat expanded and broadly obtuse, the claw very short and narrow, the auricle deep and broadly rounded. Keel mostly 8-12 mm long and 3-4 mm deep, with the apex rather acute or narrowly rounded, with the upper margin slightly curved in the centre, and sometimes with obscure longitudinal swellings near the base, the claw very short, rather narrow and curved, the auricles long, rather deep and narrowly rounded. Ovary c. $5 \mathrm{~mm}$ long, narrowly curvedovoid, with a very dense and long, fine, appressed pubescence, the apex long-tapering to a narrow style-base, the base shortly tapering and oblique. Ovules perhaps not exceeding 12 . Stipe c. $0.5-1 \mathrm{~mm}$ long, very slender, glabrous or partly pubescent. Style slender, thin-textured, or somewhat stiffened in the upper part, and somewhat flattened in the upper part, tapering only near the base and somewhat incurved tip, with or without hairs behind the tapering or very narrowly truncate tip, not twisted, the curvature virtually limited to the base, the beard fine, usually sparse in the lower part and antrorse and dense in the upper. Fruit (perhaps not mature) from 10 to c. $20 \mathrm{~mm}$ long and 5-7 mm wide, ovate or elliptic, somewhat dorsiventrally compressed but inflated, with the suture scarcely intruded, tapering at the base to a slender stipe of c. $2 \mathrm{~mm}$, and more gradually at the apex to a straight or raised beak with a somewhat basally hooked slender style of c. $5 \mathrm{~mm}$, tending to diverge from the peduncle at maturity, dehiscing along the suture and on both sides of the apex with a long or short, soft, spreading pubescence, the texture thin and rather stiff, the veins obscure, or somewhat raised, at c. $45^{\circ}-60^{\circ}$; the tissue rather firm and shallow, and absent from the ends of the loculus.

In northern inland Western Australia. Mostly in red sandy soil, and associated with mulga, but frequently on moist floodplain. Fig. 10.

Lee (1948) saw only 2 specimens of the taxon she described as S. beasleyana subsp. elegantoides; subsequent collections have shown that this erect, perhaps annual taxon 
with the funicular tissue of the fruit shallow and absent from the ends of the loculus falls in a different group from $S$. beasleyana, a procumbent perennial with a deep, even funicular tissue making the fruit bilocular.

Selected specimens (from c. 20 examined): WeStern Australia: Rudall R., George 10640, May 1971 (CANB, NT, PERTH); c. 425 km NNE of Meekatharra, Ashby 4198, 6 Aug 1971 (AD, BRI); Mt Augustus Station, Wittwer 111, 20 Aug 1973 (PERTH); c. 40 miles [65 km] from Landor on Landor-Carnarvon road, Everist 9183, 8 Sep 1969 (BRI); 50 miles [85 km] E of Meekatharra, Speck 785, 10 Sep 1957 (CANB, NSW, PERTH).

\section{S. forrestii F. Muell. ex A. Lee}

\section{(A.T. Lee 1948: 168)}

TYPE: Western Australia: Head of Menilyalya (Minilya) R., John Forrest, 1882; holo MEL; iso MEL.

An erect or spreading, single-stemmed annual, to c. $1 \mathrm{~m}$ high, with a slender taproot. Stems stout, to more than $5 \mathrm{~mm}$ wide, ribbed, at least when young, terete, or somewhat angled, the hairs dense, especially on young growth, or sparse, c. $0.5 \mathrm{~mm}$ long, very fine, terete and tapering to a very fine tip, curved and antrorse, and basifixed. Leaves mostly 5-10 cm long, with c. 13-17 leaflets above a short petiole, the leaflets narrow-ovate to narrow-elliptic or -obovate, the pubescence of loose, fine, antrorse hairs somewhat variable in length and density and usually absent from the upper surface, the lower leaflets $20-40 \mathrm{~mm}$ long and 5-10 mm wide, the terminal usually a little longer than the shortest laterals, the leaflet-apex occasionally broad but usually tapering, emarginate to broadly or narrowly rounded below a short point. Stipules broad-based, in general deltoid and very variable, with a long-attenuate tip variously extended so that the stipule may be a few millimetres long or reach more than $7 \mathrm{~mm}$, scarcely extended down the stem, green and scarious, well separated at the back, not forming an abaxial ridge and usually with a few hairs on both surfaces. Racemes often $15 \mathrm{~cm}$, sometimes up to $30 \mathrm{~cm}$ long, and frequently with 30 or more, sometimes fewer, flowers of uneven age. Peduncle $1-2.5 \mathrm{~mm}$ wide, without a pulvinus, with the flowers occupying c. $3 / 4$ of the length, conspicuously ribbed and with fine antrorse hairs. Bracts very slender, linear or lanceolate, c. 2-3 mm long. Flowers from dark brownish red to purple or pink, 9-12 $\mathrm{mm}$ long, on pedicels with dense spreading or antrorse hairs and $2-3 \mathrm{~mm}$ long. Hypanthium rather narrow, usually contracted at the apex under the fruiting calyx, the bracteoles small and linear. Calyx with the tube 2$3 \mathrm{~mm}$ long, expanding obliquely and suddenly above the hypanthium, pubescent with hairs as on the stem, the lobes very narrowly long-attenuate-deltoid and as long to twice as long as the tube, the upper a little broader, the sinuses narrow and rather acute. Standard 8-10 mm long and almost as wide, contracting to a broad tapered claw and with two vertical somewhat thickened lines towards the base. Wings c. 7$9 \mathrm{~mm}$ long, oblong or with the apex a little broader, the claw broad, short and tapered, the auricle short, rounded and somewhat folded. Keel c. $10 \mathrm{~mm}$ long and 3 $\mathrm{mm}$ deep, with the apex somewhat tapering, with the upper margin almost straight, and the lower part with two slight swellings, the claw long and rather broad, tapering, the auricles short. Ovary c. $3 \mathrm{~mm}$ long, ovate-elliptic, with a dense, or occasionally sparse, fine, antrorse pubescence, the apex tapering to a slender style-base, the base contracting and slightly oblique. Ovules perhaps not exceeding 12. Stipe c. $2 \mathrm{~mm}$ long, slender, pubescent. Style slender, thin-textured, laterally compressed in the upper part, tapering near the apex with the tip very slender, straight or incurved and with no hairs behind the stigma, not twisted, the curvature shallow and mostly near the middle, the beard dense and usually only on the upper $2 / 3$. Fruit 8 to 10 or even 13 
$\mathrm{mm}$ long and 6-8 $\mathrm{mm}$ wide, in general broadly elliptic, but somewhat dorsally compressed and variably inflated especially near the suture where often much, but sometimes not at all, indented, somewhat rounded above a slender stipe $2-3 \mathrm{~mm}$ long and tapering to a shortly acute apex below the slender 4-7 $\mathrm{mm}$ style that is strongly curved or coiled near the base, pendulous or somewhat lifted from the peduncle at maturity, dehiscing dorsally and at both ends, with a dense, or occasionally sparse, fine, soft, curved, antrorse pubescence, the texture softly to stiffly membranous, the veins scarcely visible, at c. $60^{\circ}$ or more, the tissue firm and short, and only in the central region of the suture.

In central western Western Australia. Usually in sandy or loamy, often stony, soils, especially near creekbanks or on floodplain near quartz hills. Fig. 10.

Selected SPECimens (from c. 25 examined): WeStern Australia: Nichol River, A. Forrest 1878 (MEL); c. $32 \mathrm{~km}$ from Nanutarra, Ashby 4080, 3 Aug 1971 (AD, PERTH); Kooline, near Cube Hill Bore, Beard 6173, 1 Sep 1970 (PERTH); Barlee Range, Henry River, Royce 6488, 16 Aug 1961 (PERTH); Gascoyne River, Forrest, 1882 (MEL, NSW).

\section{S. decurrens A. Lee}

\section{(A.T. Lee 1948: 170)}

TYPE: Western AustRalia: South of Marble Bar, N.T. Burbidge 1208, 14 June 1941; holo PERTH, (fragment NSW).

An erect, probably single-stemmed, annual, often c. $0.5 \mathrm{~m}$ high, with a small taproot. Stems stout, often more than $5 \mathrm{~mm}$ wide, terete, with conspicuous ribs from the nodes, with usually dense, occasionally sparse, hairs, the hairs irregularly spreading, very fine, narrow-tipped, c. $1 \mathrm{~mm}$ long, basifixed and sometimes tubercle-based. Leaves $5-15 \mathrm{~cm}$ long, with 15-19 or occasionally fewer leaflets above a usually short petiole, the leaflets narrowly elliptical, the loose pubescence, of very long, fine hairs, dense or sparse, mostly on the margins, and absent from the upper surface, the lower leaflets $10-30 \mathrm{~mm}$ long and $2-10 \mathrm{~mm}$ wide, the terminal longer or shorter than the shorter upper leaflets, the leaflet-apex acute, narrowly rounded or even cuneate to retuse, often with a short stiff point. Stipules often $10 \mathrm{~mm}$ or more long, in general lanceolate with an often long-acuminate but variably extended and often acutely lobed upper part and the lower part very variable in extension downward along a strong rib, green and leaf-like, well separated at the back, not forming an abaxial ridge and often pubescent on both surfaces but the pubescence variable and frequently only on the margins. Racemes usually $15-20 \mathrm{~cm}$ long, with c. 20-30 flowers of uneven age. Peduncle 1-1.5 mm wide, without a pulvinus, with flowers on the upper $3 / 4$ or more, ribbed or somewhat angled, villous or occasionally almost glabrous. Bracts lanceolate to very narrow, $1.5-5 \mathrm{~mm}$ long. Flowers red or purple, $8-10 \mathrm{~mm}$ long, on villous pedicels c. $5 \mathrm{~mm}$ long. Hypanthium broad at the apex, but contracting there under the fruiting calyx, the bracteoles small and linear. Calyx with the tube 2$3 \mathrm{~mm}$ long, obliquely and often broadly expanded above the hypanthium, villous to almost glabrous, the lobes narrow-deltoid, equal to the tube or longer through elongation of the narrow apices, the upper a little shorter, the sinuses narrow, acute or somewhat rounded. Standard 8-10 mm long and a little less in width, contracting to a tapering claw or tapering almost to the base, without thickening but with a concave area at the base. Wings 7-9 mm long, oblong, the apex rounded, the claw long and rather slender below the top, the auricle large and rounded, and with a fold at the base. Keel 8-10 mm long and c. $3 \mathrm{~mm}$ deep, rather acute and slightly lipped at the apex, with the upper margin slightly curved, and the basal pocket distinct, the claw quite long and slender, the auricles large and rounded. Ovary c. $2.5-4 \mathrm{~mm}$ long, 
rather broad-elliptic, glabrous or with long fine hairs along the suture or with a sparse antrorse pubescence all over, the apex tapering strongly to a broad style-base, the base more suddenly and slightly obliquely. Ovules perhaps not exceeding 12 , most aborted. Stipe c. $2 \mathrm{~mm}$ long, very slender, glabrous. Style with a broad terete base, somewhat stiffened and laterally compressed in the upper $1 / 2$, tapering only near the base and at the apex, the tip, which is contracted at the top with short stiff antrorse hairs behind the slender apex, not twisted, the curvature shallow and even, the beard dense in the upper part, sparse or absent below. Fruit 5-8 $\mathrm{mm}$ long and 4$7 \mathrm{~mm}$ wide, almost orbicular or somewhat dorsiventrally compressed, variably inflated, especially near the suture where often much indented, rounded above a very slender stipe c. $3 \mathrm{~mm}$ long and behind a minute upturned beak bearing the strongly recurved $5 \mathrm{~mm}$ style, pendulous or lifting above the horizontal at maturity, readily dehiscent on both sides, glabrous or with a few scattered long hairs, the texture thin, the veins slightly raised but delicate, at $60^{\circ}-90^{\circ}$, the tissue firm but very short to almost absent and only in the centre of the suture.

In northern Western Australia. In sandy or stony soil; recorded as occurring after fire. Fig. 11.

Selected specimens (from c. 15 examined): Western Australia: Port Hedland-Abydos trip, Donald, Oct 1946 (CANB, NSW); 9 miles [14 km] N of Marble Bar, Beauglehole 11377, 11 Aug 1965 (MEL, PERTH); $5.5 \mathrm{~km} \mathrm{~S}$ of Nullargine on track to Newman, Kenneally 7688, 28 June 1981 (PERTH); Hamersley Range, Boomsma 884, 15 July 1987 (AD); Newman, Deighton 259, 15 Aug 1982 (PERTH).

\section{S. ecallosa Sprague}

(T.A. Sprague 1903: 274)

TyPe: Western Australia: Minilya R., H.J. (comm. Barr E Sons), 28 June 02; holo K.

An erect, single-stemmed annual, to $1 \mathrm{~m}$ high, with a slender taproot. Stems stout, to more than $5 \mathrm{~mm}$ wide, ribbed, terete or sometimes strongly angled below the node, with fine, tapering, irregular, loosely divergent, straight or curved, antrorse, dense or sparse, basifixed hairs to $1 \mathrm{~mm}$ long but often much shorter. Leaves $7-10 \mathrm{~cm}$ long, with c. 17 leaflets above a short petiole, the leaflets narrowly obovate to elliptic, the pubescence of loose fine antrorse hairs variable in density and absent from the upper surface, the lower leaflets $15-25 \mathrm{~mm}$ long and 4-12 $\mathrm{mm}$ wide, the terminal almost equal to the upper, only slightly shorter than the lower, laterals, the leaflet-apex rounded or slightly emarginate, with a minute point. Stipules 2-3 $\mathrm{mm}$ long, deltoid, sometimes very shortly so, with a variably attenuate tip, green or scarious, separated at the back, not forming an abaxial ridge and usually with hairs on both surfaces. Racemes $10-20 \mathrm{~cm}$ long, with up to 20 flowers of uneven age. Peduncle (1-)2-3 mm wide, without a pulvinus, with flowers on the upper $2 / 3$, ribbed and with irregular, fine antrorse hairs. Bracts narrowly deltoid or sometimes acicular, c. $1.5 \mathrm{~mm}$ long. Flowers purple, c. $20 \mathrm{~mm}$ long, on puberulent pedicels c. $5 \mathrm{~mm}$ long. Hypanthium rather narrow, tending to contract at the apex under the fruiting calyx, the bracteoles small and linear. Calyx with the tube 3-4 mm long, gradually and obliquely expanding above the hypanthium, pubescent with hairs as on the stem, the lobes longdeltoid, acuminate, and as long to twice as long as the tube, the upper a little broader, the sinuses narrow and rather acute. Standard 15-20 $\mathrm{mm}$ long and somewhat less in width, contracting to a slender tapered claw, with a thickened area or thick lines towards the base. Wings (Fig. 4) c. $10 \mathrm{~mm}$ long, obovate, with a broad obtuse apex, the upper margin pale and transparent, the claw long, broad and tapering, the auricle rounded, extended and folded. Keel c. 16-20 mm long and 5-6 mm deep, with the 
apex shortly narrow and lipped, with the upper margin slightly curved, and without basal swellings, the claw long, with the upper $3 / 4$ scarcely tapering above the narrow base, the auricles short. Ovary c. $4 \mathrm{~mm}$ long, narrowly ovoid, with a dense, fine, appressed, antrorse pubescence, long-tapering at the apex to a slender style-base, the base contracting very obliquely. Ovules numerous but few developing. Stipe $2-3 \mathrm{~mm}$ long, very slender, pubescent. Style slender, rather thin-textured, laterally compressed in the lower part, tapering only in the upper $1 / 3$ to a very slender straight or incurved tip, with a few antrorse hairs behind the apex, not twisted, the curvature even, the beard long and fine, and usually over most of the style-length. Fruit c. 8-20 $\mathrm{mm}$ long and c. 6-8 mm wide, mostly broadly ovate somewhat dorsiventrally compressed and a little inflated, with the suture slightly and widely depressed, shortly and obliquely tapering to the base above the slender $2-3 \mathrm{~mm}$ stipe and at the apex shortly tapering to the base of the c. $12 \mathrm{~mm}$ style that is strongly curved or coiled near the base, raised above the horizontal at maturity, dehiscing along the suture and near the apex below, with a soft pubescence, especially along the suture, the texture thin and stiff, the veins obvious, sometimes strongly raised, at $60^{\circ}$, the tissue rather firm, joining the lower part of the funicles and only in the central region of the suture.

In central western Western Australia. The one habitat record is 'stony flat'. Fig. 11.

Selected spectmens (from 8 examined): Western Australia: between Gascoyne River \& Cape Farquhar, Survey Exped, 1883 (MEL); Minilya River, Gardner 3201, 28 Aug 1932 (BM, K, PERTH); 7 mile bore, Williambury Station, Cranfield 1880a, 10 Aug 1981 (PERTH); Boolathana Station, N of Carnarvon, Aplin, 5 Nov 1963 (PERTH); Carnarvon, Barnett (PERTH).

\section{S. maccullochiana F. Muell.}

(F. Mueller 1869: 25)

Type: Western Australia: Hamersley Range, Maitland Brown; holo MEL.

An erect, single-stemmed annual, 0.5 to more than $2 \mathrm{~m}$ high, the underground parts not seen. Stems very stout, to over $10 \mathrm{~mm}$ wide, ribbed, terete, or somewhat angled near the nodes, the hairs dense, of variable length, with the longest c. $2 \mathrm{~mm}$, extremely fine, terete, long-tapering to a very fine tip, spreading and basifixed. Leaves often to $20-30 \mathrm{~cm}$ long, with $15-31$ or more leaflets above a very short petiole, the leaflets broad-ovate, obovate or almost orbicular, with very fine long hairs, variable in density, confined to the lower surface, the lower leaflets mostly 20-30 mm long and 10$20 \mathrm{~mm}$ wide, the terminal not longer than the shorter upper laterals, the leaflet-apex usually acute, sometimes rounded or emarginate, the small point somewhat stiffened. Stipules to $30 \mathrm{~mm}$ long and usually more than $10 \mathrm{~mm}$, the upper part broad with a tapering apex and long acicular point, and often long-tapering acicular pointed lobes, the lower part extending to a variable extent down the stem, green, not forming an abaxial ridge and pubescent on the inner surface. Racemes often $30 \mathrm{~cm}$ or more long, with 20-40 flowers of uneven age. Peduncle frequently more than $5 \mathrm{~mm}$ wide, without a pulvinus, and with flowers mostly on the upper $1 / 2$, somewhat ribbed and with fine spreading hairs. Bracts narrow, acicular, c. $5 \mathrm{~mm}$ long. Flowers usually reddish purple or mauve, occasionally white, variable in size but usually 20$30 \mathrm{~mm}$ long, on villous pedicels c. $4 \mathrm{~mm}$ long. Hypanthium short and very broad, usually contracting at the apex under the fruiting calyx, the bracteoles small and filiform. Calyx with the tube c. $5 \mathrm{~mm}$ long, expanding obliquely above the hypanthium, shortly villous, the lobes deltoid-acuminate, the lower long-acuminate, and equal to or somewhat longer than the tube, the sinuses broad and usually rounded. Standard (Fig. 3) to c. $30 \mathrm{~mm}$ long and 20-25 mm wide, tapering to the base or with a tapering claw, with, in the lower part, two very strong ridges almost encircling a 
broad concave area. Wings c. $25 \mathrm{~mm}$ long, narrowly oblong and obtuse, the claw very short and tapered, the auricle rather deep, rounded and somewhat folded. Keel usually c. $30 \mathrm{~mm}$ long and c. $6 \mathrm{~mm}$ deep, with a rather narrow acute tip and straight upper margin and with a little pubescence, and with big longitudinal swellings in the lower part, the claw very short, the auricles rather deep. Ovary c. $5 \mathrm{~mm}$ long, narrowly ovate-oblong, with a dense, fine and appressed pubescence, the apex long-tapering to a slender style-base, the base narrow and not conspicuously oblique. Ovules numerous. Stipe c. 4-6 mm long, slender, pubescent. Style slender, thin-textured, laterally compressed, very gradually tapering to a very slender straight tip with no tuft of hairs behind it, not twisted, the curvature shallow and even, the beard dense and usually over most of the style-length. Fruit 30-35 mm long and more than $10 \mathrm{~mm}$ wide, elliptical, somewhat dorsiventrally compressed and somewhat inflated, with little intrusion of the suture, tapering to a slender stipe c. $5 \mathrm{~mm}$ long and to the base of the c. $15 \mathrm{~mm}$, often recurved and sometimes spiral, style, raised above the horizontal at maturity, dehiscing dorsally near the apex, the fine soft pubescence dense near the suture, the texture softly or stiffly membranous, the veins visible, at $60^{\circ}$, the lower part of the stout funicles in a firm tissue deepest in the central part of the suture.

In central western Western Australia. In loamy soil in low-lying moist areas. Fig. 11.

Selected SPECIMENS (from c. 30 examined): WeSTERn Australia: S of Nullargine, Scott 84 (AD); 67 km from Nanutarra, Ashby 4091, 3 Aug 1971 (AD, K, MEL); Mt Tom Price, Stephens 11 Nov 1980 (NSW); Wanna, Beard 6055, 19 Aug 1970 (NSW, PERTH); above Lyons River, Mt Augustus Station, Wittwer 1057, 18 Aug 1973 (PERTH).

\section{Group 3}

1 Flowers mostly 50-60 mm long; keel long-tapering to a narrow tip; peduncle scarcely or not pulvinate; fruit 40-90 $\mathrm{mm}$ long

19. S. formosa

$1^{*}$ Flowers less than $30 \mathrm{~mm}$ long; keel not as above; peduncle with an obscure or obvious pulvinus; fruit less than $30 \mathrm{~mm}$ long

2 Flowers more than $15 \mathrm{~mm}$ long; leaflets usually 15 or more, with loosely appressed hairs 20. S. beasleyana

2* Flowers $15 \mathrm{~mm}$ or less long; leaflets 15 or less, with spreading or loosely appressed hairs

3 Style little-tapered and with an obliquely truncate tip bearing an arc of hairs behind the stigma

26. S. villosa

$3^{*}$ Style tapering to a tip without hairs

4 Keel with an awl-shaped extension either side of the apex

21. S. cornuta

$4^{*}$ Keel not as above

5 Leaflets 3-7 (usually 5); stipules narrow and without lateral teeth; peduncles slender and strawlike

6 Flowers c. $8 \mathrm{~mm}$ long

22. S. longipilosa

6* Flowers $10-15 \mathrm{~mm}$ long

23. S. pedunculata

5* Leaflets 7-15; stipules broad and conspicuously toothed, peduncles not as above

7 Flowers 12-15 mm long; keel conspicuously longer than the wings; leaflets with a spreading pubescence

24. S. calcicola

$7^{*}$ Flowers 8-10 mm long; keel scarcely longer than the wings; leaflets with a loosely appressed pubescence

25. S. elegans 


\section{S. formosa (G. Don) J. Thompson}

\section{(J. Thompson 1990: 4)}

Basionym: Donia formosa G. Don (G. Don 1832: 468); Clianthus formosus (G. Don) Ford \& Vickery (N.C. Ford \& J.W. Vickery 1950: 302); Clianthus dampieri Cunn. ex Lindl. (J. Lindley 1835: ser.2,1:519,t.22).

TYPE: Western Australia: Curlew R., King; holo BM.

C. dampieri var. marginata Dombr. (H.H. Dombrain 1866: t. 274). TYPE: the plate.

Donia speciosa G. Don (G. Don 1832: 468); Clianthus speciosus (G. Don) Ascherson \& Graebner (P.F.A. Ascherson \& K.O.R.P.P. Graebner 1909: 725) non Steud. (1840-1); Clianthus oxleyi Cunn. ex. Lindl. (J. Lindley 1835: ser.2,1:519,t.22). Type: New SoutH Wales: South Western Plains: Regents Lake, A. Cunningham; holo K; iso BM.

A prostrate annual or short-lived perennial with several stems from a taproot. Stems very stout, mostly $4-8 \mathrm{~mm}$ wide, terete or somewhat ribbed, sometimes somewhat ridged, below the nodes, densely pubescent with long, fine hairs of varying length, most 1-2 mm long, spreading, and basifixed. Leaves (5-)10-15 cm long, with c. 15 leaflets above a short or a little extended petiole, the leaflets elliptic to obovate, often broadly so, with long fine spreading hairs on the lower and occasionally upper surfaces, the lower leaflets usually $10-30 \mathrm{~cm}$ long and 5-12 mm wide, the terminal often longer than the somewhat shorter upper laterals, the leaflet-apex acute to broadly rounded, occasionally retuse, usually with a minute point. Stipules often $15 \mathrm{~mm}$ or more, very broad with a suddenly tapering acicular apex and occasionally short lateral teeth, not much, if at all, extended down the stem, green, at the back often adjacent but apparently not forming an abaxial ridge, and densely pubescent on both sides. Racemes mostly 10-15 cm long, with 2-6 flowers of almost even age, and with the part above them aborted. Peduncle usually 3-4 mm wide, usually narrowed above the lowest flower, scarcely if at all pulvinate, with flowers only in the top centimetre, ribbed, with fine long spreading hairs. Bracts broad, ovate-lanceolate, long-acuminate, mostly 5-6 mm long. Flowers red, white or parti-coloured, mostly $50-60 \mathrm{~mm}$ long, on villous pedicels c. $15 \mathrm{~mm}$ long. Hypanthium often long-attenuate at the base, conspicuously contracted at the top under the fruiting calyx, the bracteoles long-tapering, often $5 \mathrm{~mm}$ or more long. Calyx with the tube 5-6 mm long, broadly and obliquely expanding above the hypanthium, with a dense spreading pubescence, the lobes narrowly ovate-lanceolate with filiform tips, often twice as long as the tube, the sinuses narrow. Standard $40-60 \mathrm{~mm}$ long and very narrow, c. 1/3 or less in width, tapering to a tapered claw, with a concave area above, with two angled thickenings above it and below a large, usually dark boss c. $1 \mathrm{~cm}$ across, gradually tapering to a narrow tip. Wings c. 35-40 mm long, curved-narrow-deltoid, tapering gradually to a narrow acute tip, the claw slenderly tapered, and somewhat curved, the auricle very deep and broadly rounded. Keel usually 50-60 mm long and 12-15 $\mathrm{mm}$ deep, with the apex long-tapering to a narrow acute tip, with the upper margin curved, more strongly towards the tip, sometimes a little curved the other way towards the base, and without folds, the claw short, recurved and scarcely tapered, the auricles deep but narrowing to broadly deltoid. Ovary c. $20 \mathrm{~mm}$ long, narrowly elliptic, with a dense pubescence of long fine hairs that tend to lift especially along the suture and even recurve near its base; long-tapering at the apex to a slender stylebase, and rather gradually tapering at the base. Ovules numerous. Stipe c. $5 \mathrm{~mm}$ long, slender, straight but at an angle, pubescent. Style thin-textured and somewhat grooved, laterally compressed above a short terete base, very slender so tapering only very gradually, with more taper near the tip, to a very slender tip without a tuft of hairs, 
not twisted, the curvature slight with most near the base, the beard of antrorse ovaryhairs near the base, then absent below the upper c. $5 \mathrm{~mm}$ where antrorse. Fruit $40-90$ $\mathrm{mm}$ long and 10-12 $\mathrm{mm}$ wide, narrowly elliptic-oblong, dorsiventrally compressed with the suture broadly or deeply intruded depending on the amount of inflation, variably tapered at the base above a stipe 5-15 $\mathrm{mm}$ long, and at the apex tapering or, more usually, rounded behind a very slender straight beak subtending the straightening style of $30-40 \mathrm{~mm}$ or its remains, pendulous or becoming raised at maturity, dehiscent at first along the suture, later along both sides and the stipe, densely pubescent, the texture rigid, the veins obscure or somewhat raised, at c. $60^{\circ}-90^{\circ}$, the tissue even, linking half the funicles.

Widespread in dry parts of Western Australia, South Australia and New South Wales, in the southern part of the Northern Territory and recorded for Queensland (records not supported by specimens). Usually in red sandy or loamy soils in open areas or in mulga woodland. Fig. 12.

Selected specimens (from c. 170 examined): Western Australia: Great Northern Highway, 67 miles [105 km] S of Port Hedland, Olsen 517, 3 July 1967 (NSW); $19 \mathrm{~km} \mathrm{~S} \mathrm{of} \mathrm{Forrest,} \mathrm{Aplin} \mathrm{1706,}$ 2 Sep 1964 (K, NSW, PERTH). South Australia: between Coober Pedy \& Kulgera, Eichler 17247, 2 Sep 1963 (AD, NSW); 20 miles [32 km] N of Maralinga \& around Emu, Bowen 4, Sep 1956 (K, NSW). New South WaLEs: Broken Hill, Morris 375, 1 Sep 1920 (NSW).

\section{S. beasleyana F. Muell.}

\section{(F. Mueller 1887: 84)}

TyPe: Western Australia: near Lake Austin, H.S. King (1), 1886; lecto (fide Lee 1948: 191) MEL.

A procumbent perennial reaching c. $30 \mathrm{~cm}$ high, with numerous stems from the top of a taproot. Stems often c. 3 but to c. $8 \mathrm{~mm}$ wide, terete, often with ridges from the nodes, often conspicuously flexuose, with rather dense, very long and fine hairs, the hairs c. 1 or even $1.5 \mathrm{~mm}$ long, tapering to the tip, rarely straight, irregularly spreading to curved-antrorse or loosely appressed, basifixed. Leaves 5-10(-15) mm long, usually with 15-19 leaflets above a short or occasionally elongated petiole, the leaflets obovate-elliptic, variable in size (on one plant and between plants), with loosely appressed, irregular, fine hairs on both surfaces but more dense on the lower, the lower leaflets 3-30 $\mathrm{mm}$ long and 2-11 $\mathrm{mm}$ wide, the terminal usually larger than the shorter upper laterals, the leaflet-apex acute with a recurved point, or rounded or even retuse. Stipules (Fig. 1) often $15 \mathrm{~mm}$ long and as broad, smaller when leaves are smaller, obliquely ovate to broader than long, with a number of acuminate lateral lobes, green, sometimes somewhat extended down the stem, not forming an abaxial ridge and densely pubescent on both sides. Racemes (8-)20-30(-40) cm long, usually with 3-8 flowers of almost even age. Peduncle mostly $2-4 \mathrm{~mm}$ wide, with a conspicuous, often dark, pulvinus, with flowers over $1 / 3$, often very much less, of its length, scarcely or shallowly ribbed, with sparse hairs on the upper part or glabrous. Bracts linear-lanceolate, 3-4 mm long. Flowers pale- or dark-purple, 17-22 mm long, on pubescent pedicels $2-5 \mathrm{~mm}$ long. Hypanthium (Fig. 2) often long-tapering, slightly contracted at the top under the fruiting calyx, the bracteoles linear-lanceolate and sometimes $1 \mathrm{~mm}$ or more long. Calyx (Fig. 2) with the tube c. $3 \mathrm{~mm}$ long, expanding only a little above the hypanthium, with a rather sparse, sometimes appressed, fine pubescence, the lobes long-acuminate-deltoid, equal to or a little longer than the tube, not dissimilar, the sinuses usually narrowly rounded. Standard 15-25 mm long and 10-20 mm wide, rather rounded above a short slender tapered claw, with two spaced horizontal calli near the base. Wings to $15 \mathrm{~mm}$ long, obliquely obovate (the lower 
edge longer), much and asymmetrically expanded at the apex where almost truncate, the claw short, scarcely and variably tapered, and curved, the auricle deep but narrow, and rounded. Keel to $22 \mathrm{~mm}$ long and $8 \mathrm{~mm}$ deep, with the apex obtuse, with the upper margin curved downward just behind the tip and upward towards the base, and with shallow folds from the auricles, the claw short, recurved and shortly tapered, the auricles rather shallow and recurved. Ovary c. 8-10 $\mathrm{mm}$ long, obliquely elliptic, curved, glabrous apart from fine hairs along the suture, tapering at the apex to a narrow style-base and more suddenly and very obliquely at the base. Ovules numerous. Stipe c. $2.5 \mathrm{~mm}$ long, slender, straight but at an angle, glabrous. Style slender, thin-textured, laterally compressed above the terete base, tapering only in the upper half to a slender incurved tip without a tuft of hairs, not twisted, the curvature mostly near the base, slight but still obvious above, the beard dense and along the whole length. Fruit c. 20-25 mm long and 5-7 mm wide, narrowly oblong or somewhat obovate, sometimes somewhat curved, inflated but strongly dorsiventrally compressed with the suture broadly or deeply (when there is more vertical inflation) intruded, often with the lower edge also intruded, shortly tapered at the base to a narrow stipe of c. $2.5 \mathrm{~mm}$, and rounded or shortly tapered at the apex to an upturned or recurved beak below a recurved style c. $7 \mathrm{~mm}$ long that is sometimes twisted near the base and occasionally a little thickened, becoming erect at maturity, dehiscent at least along the suture, pale-coloured, with hairs few, mostly only near the base of the suture, the texture stiffly leathery, the veins delicate, at $90^{\circ}$ or a little less, the tissue linking half the funicles, even, and closing the loculus.

In inland south-western Western Australia. Associated with soakage areas in red, sandy or gravelly, loam soils. Fig. 12.

SELECTED SPECIMENS (from 32 examined): Western Australia: c. $60 \mathrm{~km} \mathrm{~W}$ of Anketell, on the Mt Magnet road, Ashby 2598, 13 Sep 1968 (AD, PERTH); Cashmere Downs, Beard 6496, 9 Sep 1973 (NSW PERTH); 7 miles [11 km] W of Karonie, George 5920, 22 Sep 1966 (MEL, NSW, PERTH); c. $5 \mathrm{~km} \mathrm{SW}$ of Kambalda, Donner 4629, 8 Sep 1973 (AD, CANB); $7 \mathrm{~km} \mathrm{~N}$ of Widgiemooltha, M.M.H. Thompson JT4622, 5 Oct 1987 (NSW).

\section{S. cornuta J. Thompson, sp. nov.}

Herba procumbens annua vel perennis probabiliter minus quam $20 \mathrm{~cm}$ alta. Foliola c. 7, elliptica. Racemi usque ad $15 \mathrm{~cm}$ longi vel ultra, floribus $10-15 \mathrm{~mm}$ longis. Calyx lobis longi-acuminatis tubo valde longioribus. Vexillum versus basim non incrassatum sed concavum. Carina obtusa cornuta. Stylus angustatus apice incurvo.

Type: Western Australia c. $850 \mathrm{~km}$ post on Carnarvon Highway, H. Demarz D3878, 21 Aug 1972; holo PERTH.

A procumbent annual or perennial, probably not reaching $20 \mathrm{~cm}$ high, with one to numerous stems from the top of a taproot. Stems c. $2 \mathrm{~mm}$ wide, terete, rather obscurely ribbed, with dense long, very fine hairs up to $0.75 \mathrm{~mm}$ long, tapering to the tip, spreading and basifixed. Leaves less than $5 \mathrm{~cm}$ long, with $\mathrm{c} .7$ leaflets above a petiole of variable length, the leaflets elliptic, with long, fine, spreading hairs on both surfaces but less dense on the upper, the lower leaflets to $10 \mathrm{~mm}$ long and $5 \mathrm{~mm}$ wide, perhaps smaller on older plants, the terminal at least sometimes largest, the leafletapex usually shortly acute with a small, stiff, recurved point. Stipules to c. $10 \mathrm{~mm}$ long, obliquely ovate to broader than long, and often extended somewhat down the stem, with numerous acuminate lateral lobes, green, not forming an abaxial ridge, and pubescent on both sides. Racemes to $15 \mathrm{~cm}$ or more long, with c. 3-7 flowers of slightly uneven age. Peduncle c. $1 \mathrm{~mm}$ wide, with a pulvinus somewhat developed, with flowers only in the top 2 or $3 \mathrm{~cm}$, ribbed, sometimes obscurely, with scattered 
irregular fine hairs or glabrous. Bracts slender, c. $3 \mathrm{~mm}$ long. Flowers purple, 10-15 $\mathrm{mm}$ long, on pubescent pedicels c. $3 \mathrm{~mm}$ long. Hypanthium slender with narrowly linear bracteoles. Calyx with the tube c. $1.5 \mathrm{~mm}$ long, gradually or more broadly expanding above the hypanthium, pubescent with loose, fine, antrorse hairs, the lobes long-acuminate-deltoid, much longer than the tube, the upper a little shorter and broader than the lower, the sinuses narrowly rounded. Standard 10-15 mm long and $8-12 \mathrm{~mm}$ wide, tapering to the base or shortly rounded above a short slender claw, without thickenings but concave near the base. Wings 7-8 mm long, obovate, the apex variably expanded, sometimes thin-textured, shortly and broadly obtuse, the claw short, broad and much tapered, the auricle deep and rounded. Keel (Fig. 5) 8-9 $\mathrm{mm}$ long and c. $4 \mathrm{~mm}$ deep, with the apex obtuse and with two slender soft, awlshaped extensions at the end, c. $1.5 \mathrm{~mm}$ below the tip, with the upper margin curved upward behind the tip, and without conspicuous swellings near the base, the claw short, broad and tapered, the auricles little-developed. Ovary 3-5 mm long, curved, oblong-elliptic, with long appressed hairs, antrorse except for a few at the base; tapering, perhaps little when very young, to a broad style-base, and very suddenly and very obliquely at the base. Ovules probably numerous. Stipe c. $0.5 \mathrm{~mm}$ long, slender, partly glabrous. Style c. $4 \mathrm{~mm}$ long, slender, thin-textured and grooved, laterally compressed, gradually tapering to a very slender incurved tip without a tuft of hairs, not twisted, the curvature strong in the lower part, slight above, the beard along the whole length but somewhat shorter and denser, and a little antrorse, in the upper part. Fruit not seen.

Known from one locality near the western coast of Western Australia. In red clay. Fig. 12.

This species is named for the projections on the keel-apex. From the Latin cornutus, horned.

SPECIMENS EXAMINED: WesteRn AustRAlia: Wooramel, D.G.W., 17 Oct 1955 (PERTH).

\section{S. longipilosa J. Thompson, sp. nov.}

Herba forsan annua c. $4 \mathrm{~cm}$ alta. Foliola c. 5, obovata. Racemi $1-3 \mathrm{~cm}$ longi, floribus c. $8 \mathrm{~mm}$ longis. Calyx lobis lanceolatis longi-acuminatis tubo c. 3-plo longioribus. Vexillum versus basim lineis crassis. Stylus angustatus apice incurvo vel inflexo. Fructus c. $15 \mathrm{~mm}$ longus.

TYPE: WeSTERN Australia: Ex SB119, Williamsbury Station, R.J. Cranfield 1851, 9 Aug 1981; holo PERTH.

A small, perhaps annual plant c. $4 \mathrm{~cm}$ high, with one or several short stems from the top of a slender taproot. Stems c. $1 \mathrm{~mm}$ wide, ribbed and somewhat flattened below the nodes, densely pubescent with very long, widely spreading, very slender hairs, often c. $1 \mathrm{~mm}$ long and tending to be flattened and spiral, with a very narrow apex, and basifixed. Leaves to $2 \mathrm{~cm}$ long, with c. 5 leaflets above an often extended petiole, the leaflets obovate, the pubescence long, very fine and spreading but absent from most of the upper surface, the lateral leaflets $5-8 \mathrm{~mm}$ long and $2-3 \mathrm{~mm}$ wide, the terminal somewhat larger, the leaflet-apex shortly tapered with a short point. Stipules up to c. $7 \mathrm{~mm}$ long, very narrow above, with acute lateral teeth on both sides, green, widely separated, not forming an abaxial ridge and with hairs on both surfaces. Racemes 1-5 cm long, with 1-3 flowers. Peduncle less than $0.5 \mathrm{~mm}$ wide, with a small pulvinus, somewhat angled, glabrous or occasionally with long spreading hairs, sometimes extending beyond the flowers. Bracts narrowly acuminate, c. $2 \mathrm{~mm}$ long. Flowers reddish-purple, c. $8 \mathrm{~mm}$ long, on a pedicel of less than $1 \mathrm{~mm}$. Hypanthium rather narrow, not contracting under the fruiting calyx, the bracteoles minute. Calyx with 
the tube c. $1 \mathrm{~mm}$ long, gradually and only a little expanding above the hypanthiumtop, with very fine spreading hairs, the lobes not dissimilar, very long lanceolatedeltoid and acuminate, c. 3 times as long as the tube, the sinuses narrowly rounded. Standard 6-8 $\mathrm{mm}$ long and c. $7 \mathrm{~mm}$ broad, tapering abruptly to a tapered claw, with two minute calli at the base. Wings 5-6 mm long, narrowly obovate, the apex rounded but not very broad, the claw very short, somewhat tapered and slightly curved, the auricle very small, somewhat rounded and folded. Keel 8-9 $\mathrm{mm}$ long and 3-4 mm deep, with the upper margin with an even upward curve from the apex to the scarcely perceptible auricles, without pockets but infolded at the base just beyond the claw, the claw very short, straight and little tapered. Ovary c. $4 \mathrm{~mm}$ long, elliptic, curved, with dense and very long and loosely appressed hairs, antrorse except for a few on the sutural side near the base; tapering at the apex and rather suddenly and obliquely at the base. Ovules numerous. Stipe c. $0.5 \mathrm{~mm}$ long, slender, glabrous. Style slender but somewhat broader at the base and tapering gradually to a very slender incurved or inflexed tip, laterally flattened and tending to twist, pale but not thickened, curved strongly only in the lower part and at the tip, the beard sparse, long and over the whole length including the tip. Fruit c. $15 \mathrm{~mm}$ long and $3 \mathrm{~mm}$ wide, oblong and curved, somewhat inflated but with the suture deeply and the lower margin a little indented so as to close the loculus; tapered at the base and shortly tapered at the broad apex behind a recurved style of c. $4 \mathrm{~mm}$, almost erect at maturity but dehiscence not seen, with long fine spreading hairs, the texture stiffly leathery, the veins obscure at c. $90^{\circ}$, the tissue short and even assuring closure of the loculus.

Known from only two localities in central western Western Australia. On a stony exposed hilltop and in Acacia woodland. Fig. 12.

This species is named for the long hairs on vegetative growth and the ovary. From the Latin longus, long; pilus, hair.

SPECIMENS EXAMINED: WeSteRn Australia: $8.9 \mathrm{~km}$ W of Mount Vernon homestead, Chinnock \& Chinnock 16, 9 Sep 1986 (AD).

\section{S. pedunculata $A$. Lee}

\section{(A.T. Lee 1948: 171)}

Type: Western Australia: Kennedy Ra., C.A. Gardner 6430, Sep 1941; holo PERTH; iso PERTH.

A small ascending, perhaps annual, plant $20 \mathrm{~cm}$ or less high, with a few to numerous stems and a slender taproot. Stems often $2(-3) \mathrm{mm}$ wide, terete, strongly ribbed or almost angled when young, with few to dense hairs, the hairs tapering, fine-pointed, often somewhat flattened, spreading or appressed, antrorse, mostly $0.5 \mathrm{~mm}$ but sometimes $0.75 \mathrm{~mm}$ long and basifixed or laterally attached near the base. Leaves usually less than $5 \mathrm{~cm}$ long, with 3-7 (usually 5) leaflets above an often rather long petiole, the leaflets narrowly elliptical or lanceolate, the pubescence as for the stem but sparse on the upper surface, the lower leaflets mostly 10-20 mm long and 1-2 mm wide, the terminal conspicuously larger, the leaflet-apex acute or narrowly rounded with a small rather stout point. Stipules often $5 \mathrm{~mm}$ long, usually linear-lanceolate, the base narrow and angled, green, widely separated, not forming an abaxial ridge and with a few hairs on each surface. Racemes to c. $15 \mathrm{~cm}$ long, with 2 or 3 flowers of approximately the same age. Peduncle c. $0.5 \mathrm{~mm}$ wide, more rigid than the leaf-rhachis, with a very conspicuous enlarged and coloured pulvinus, with the flowers in the upper few centimetres, usually angled from the few and distinct ribs and soon becoming straw-coloured, glabrous, or almost so, except for dense hairs on the pulvinus. Bracts 
linear-lanceolate, c. $1 \mathrm{~mm}$ long. Flowers probably purple, 10-15 mm long, on sparsely pubescent pedicels c. 1-2 mm long. Hypanthium slender, somewhat contracted at the apex in the fruit, the bracteoles linear and minute. Caly $x$ with the tube c. $2 \mathrm{~mm}$ long, broadly and not very obliquely expanded above the hypanthium, glabrous or with sparse hairs, the lobes long-deltoid and often long-tapered, c. twice the length of the tube, not very dissimilar, the sinuses narrowly rounded. Standard to $15 \mathrm{~mm}$ long and as wide or wider, almost truncate above a very short tapered claw, with two very stout, often confluent, thickenings conspicuous at the top of the claw. Wings 10-15 $\mathrm{mm}$ long, broadly obovate, the very broad apex very shortly obtuse, the short claw slender and curved, the auricle small, rounded and incurved. Keel to $10 \mathrm{~mm}$ or more long and c. $5 \mathrm{~mm}$ deep, with the apex acute and upturned, with the upper margin curved behind the apex, without folds or pockets but with dense hairs on the sides near the base, the claw quite long and slender, the auricles short and almost truncate. Ovary c. $4 \mathrm{~mm}$ long, oblong, with dense, long, fine, appressed hairs, tapering rather little, and somewhat downcurved, at the apex and at the base obliquely contracting to the stipe. Ovules numerous. Stipe $0.5 \mathrm{~mm}$ long, broad, pubescent. Style thin-textured, flattened, broad-based and gradually tapering to a very fine slender apex, with no hairs behind the stigma, not twisted, the curvature strong at the base, slight or absent above and slightly reversed near the tip, the beard in the upper $2 / 3$, antrorse. Fruit c. $25 \mathrm{~mm}$ long and $3 \mathrm{~mm}$ wide, narrowly elliptic and curved, somewhat inflated but with the suture deeply, and the lower margin a little, indented, i.e. the fruit folded; shortly tapered at the base to a variable stipe, and more gradually at the acute apex with a recurved c. $6 \mathrm{~mm}$ style, becoming erect at maturity, dehiscent perhaps at the suture, with appressed fine hairs, the texture softly leathery, the veins delicate, obscure, at c. $90^{\circ}$, the tissue deep, even and closing the loculus.

In central western Western Australia. In rocky or stony places. Fig. 13.

SPECIMENS EXAMINED: WESTERN Australia: Gascoyne River, Forrest, 1882 (MEL); Bidgemia Station, near Weedarrah outcamp, Wilcox, Sep 1970 (PERTH); 1-5 miles [2.5-8 km] W of Gascoyne Junction, Ashby 4755, 30 June 1973 (AD); Upper Murchison River near Mt Hale, Crossland, 1884 (MEL); 22 miles [35 km] N of Meekatharra, Speck 1089, 2 July 1958 (CANB, NSW, PERTH).

\section{S. calcicola J. Thompson, sp. nov.}

Herba humilis prostrata vel ascendens perennis. Foliola plerumque 7-11 late obovata. Racemi 5-25 cm longi floribus 12-15 mm longis. Calyx lobis tubo interdum longioribus. Vexillum versus basim lineis crassis. Carina obtusa subrostrata. Stylus angustatus apice breviter incurvo. Fructus c. $25 \mathrm{~mm}$ longus $6-8 \mathrm{~mm}$ latus suboblongus depressus.

Type: Western Australia: c. $28 \mathrm{~km}$ NE of Ningaloo Station Homestead, A.S. George 10243, 5 Sep 1970; holo PERTH.

A prostrate or ascending low-growing perennial, with numerous stems from a taproot, perhaps becoming rhizomatous. Stems mostly 2-3 $\mathrm{mm}$ wide, terete or somewhat angled from the nodes, obscurely ribbed, occasionally obviously flexuose, with rather dense and very long hairs, $0.75-1 \mathrm{~mm}$ long, fine, tapering to the tip, slightly irregular, spreading to somewhat antrorse or retrorse and basifixed. Leaves to $10 \mathrm{~cm}$ long but often shorter, usually with 7-11 leaflets above a usually short petiole, the leaflets broadly obovate, with an, often dense, long spreading pubescence on both surfaces, the lower leaflets usually 7-12 $\mathrm{mm}$ long and 4-8 $\mathrm{mm}$ broad, the terminal often larger than the shorter upper laterals, the leaflet-apex mostly broadly rounded with a short recurved point. Stipules often more than $10 \mathrm{~mm}$ long, often very broad but varying in size and shape independently from the leaves, with long acuminate lateral lobes, green, often tending to extend down the stem, not forming an abaxial ridge, and 
pubescent, usually densely, on both surfaces. Racemes 5-25 cm long, with (1-)4-5(-9) flowers of almost even age. Peduncle from less than 1 to $2.5 \mathrm{~mm}$ wide, with a conspicuous, often dark, pulvinus, with flowers in the upper $1 / 2$ to $1 / 6$ of its length, terete or scarcely ribbed, the lower part usually glabrous but usually with some pubescence near the flowers. Bracts c. $2 \mathrm{~mm}$ long, ovate-lanceolate. Flowers pink- or red-purple, 12-15 $\mathrm{mm}$ long, on pubescent pedicels 1-3 mm long. Hypanthium rather broad, contracting at the top under the fruiting calyx, the bracteoles linear and small. Calyx with the tube 2-2.5 mm long, gradually expanding above the hypanthium, with a loose, antrorsely spreading, fine pubescence, the lobes ovate to broad-lanceolate and acute to acuminate, equal to or, more frequently, longer than the tube, the upper sometimes somewhat broader, the sinuses narrow but rounded. Standard 10-15 mm long and 8-11 $\mathrm{mm}$ wide, tapering to, or rounded above, a short rather broad tapered claw, with two shallow angled thickenings below a perhaps slightly concave area. Wings 6-12 mm long, narrowly oblong, the tip shortly obtuse and rather oblique (the lower margin longer), the claw not short, tapered strongly and curved, the auricle rather deep and long, rounded to almost deltoid. Keel (Fig. 5) 10-15 mm long and to $6 \mathrm{~mm}$ deep, with the apex obtuse but somewhat lipped and beaked, with the upper margin sometimes curved downward just behind the tip, and always strongly curved upward (above the horizontal) behind this, and with shallow folds near the auricles, the claw short, scarcely tapered and straight, the auricles narrow, long and deltoid or rounded. Ovary 5-6 mm long, obliquely oblong-elliptic, somewhat curved, with a dense long appressed pubescence, tapering somewhat obliquely at the apex to a rather broad style-base and more suddenly and very obliquely at the base. Ovules numerous. Stipe c. $0.5 \mathrm{~mm}$ long, rather slender, glabrous. Style slender, thin-textured and laterally grooved, laterally compressed, tapering gradually to behind a shortly incurved tip without a tuft of hairs, not twisted, the curvature even or less in the upper part (but still obvious there), the beard often rather sparse, shorter towards the tip. Fruit c. $25 \mathrm{~mm}$ long and 6-8 $\mathrm{mm}$ wide, oblong or broader near the apex, sometimes curved, somewhat, often only slightly, inflated, usually strongly dorsiventrally compressed with the suture usually not much intruded, shortly tapered at the base to a stipe of 1-2 $\mathrm{mm}$, and at the apex to a short straight or somewhat raised beak bearing the c. $7 \mathrm{~mm}$ recurved style, becoming erect at maturity, dehiscent along the suture, with a loose fine pubescence, the texture rather stiffly leathery, the veins slightly raised, at c. $45^{\circ}-60^{\circ}$, the tissue firm, short and even.

On the coast and off-shore islands of Western Australia. In sand, especially on coastal limestone. Fig. 13.

This species is named for its habitat on calcareous sand and limestone. From the Latin calcium, calcium; -cola, dweller.

Selected SPECIMENS (from 12 examined): WESTERn Australia: Trimouille Island, Monte Bello, Hill, 10 Nov 1953 (CANB); c. $50 \mathrm{~km} \mathrm{~S}$ of Ningaloo Homestead towards Coral Bay, Weber 5012, 6 Oct 1975 (AD); Quobba, N of Carnarvon, George 10144, 3 Sep 1970 (PERTH); Blowhole, Carnarvon, Wittwer 1798, 11 Aug 1976 (PERTH); Abrolhos Islands, Alexander B1130, Nov 1913 (PERTH).

25. S. elegans A. Lee

(A.T. Lee 1948: 189)

Type: Western Australia: 9 miles [15 km] E of Carnarvon, Meadley, 9 July 1937; holo PERTH; iso $\mathrm{K}$.

A prostrate or ascending, perhaps annual, plant, to $25 \mathrm{~cm}$ high, with one to numerous stems from the top of a short slender taproot. Stems (1-)2(-4) $\mathrm{mm}$ wide, terete, often 
with ridges below the nodes, with sparse to dense hairs, the hairs long, fine, c. 0.75 $\mathrm{mm}$, terete and tapering to the tip, irregularly antrorse or rather appressed and basifixed. Leaves to c. $10 \mathrm{~cm}$ long, with $7-15$ leaflets above a variably extended petiole, the leaflets obovate or elliptic, with fine loosely appressed hairs on both surfaces but more dense on the lower, the lower leaflets $10-20 \mathrm{~mm}$ long and mostly 2-5 mm wide, the terminal usually larger than the shorter upper laterals, the leaflet-apex usually acute, recurved and pointed. Stipules often $10 \mathrm{~mm}$ long, even when the leaves are small, but variable in size, obliquely ovate to broader than long, with numerous acuminate laterals lobes, green, extending to a variable extent down the stem, not forming an abaxial ridge and densely pubescent on both surfaces, especially the upper. Racemes mostly 10-20 cm long, with a few or up to c. 15 flowers of only slightly uneven age. Peduncle usually 1-2 mm wide, with a conspicuous, often dark, pulvinus, with flowers in the top $1 / 2$ to $1 / 4$, scarcely ribbed, glabrous except for fine hairs on the upper part. Bracts lanceolate, c. $2 \mathrm{~mm}$ long. Flowers pale- or dark-, blueor red-purple, $8-10 \mathrm{~mm}$ long, on rather sparsely pubescent pedicels often c. $4 \mathrm{~mm}$ long. Hypanthium slender, somewhat contracted at the top under the fruiting calyx, with minute linear bracteoles. Calyx with the tube c. $2 \mathrm{~mm}$ long, expanding, but not widely so, above the hypanthium, with a fine, loosely appressed, antrorse pubescence, the lobes long-acuminate-deltoid, approximately as long as the tube, the upper a little broader than the lower, the sinuses deltoid or rounded. Standard $10-13 \mathrm{~mm}$ long and 9-12 $\mathrm{mm}$ wide, tapering to the narrow base or rounded above a very short slender claw, with or without thickenings below a concave basal area. Wings 8-9 mm long, narrowly obovate or oblong, rather variably expanded at the broad apex where shortly rounded, and sometimes thin-textured, the claw short, slender and curved, the auricle deep and rounded. Keel c. $10 \mathrm{~mm}$ long and c. $3 \mathrm{~mm}$ deep, with the apex obtuse, with the upper margin almost straight, and with shallow swellings near the base, the claw rather long and slender, tapering, the auricles about as deep and shallowly rounded. Ovary 4-5 mm long, narrowly oblong-elliptic, somewhat curved, with long appressed antrorse hairs on the sutural side, the hairs reversed at the extreme base, scarcely tapering or even expanded at the apex to the style-base, and suddenly and obliquely contracting at the base. Ovules numerous. Stipe c. $0.5 \mathrm{~mm}$ long, slender, somewhat curved, partly glabrous. Style especially thin-textured at the base, and usually stiffened in the central part, laterally compressed, tapering from the very broad base and more suddenly behind a very slender inflexed tip without a tuft of hairs, not twisted, the curvature rather even but not strong, the beard along the whole length but more dense and long on the upper part and slender tip. Fruit 15-20 mm long and 4-6 mm wide, narrowly obovate to almost oblong, sometimes somewhat curved, somewhat inflated but strongly dorsiventrally compressed, with the suture widely or (if there is more vertical inflation) deeply intruded, variably tapering to an attenuate base above a tapered stipe c. $1.5 \mathrm{~mm}$ long, at the apex broadly acute or rounded behind a raised beak below a style c. $5 \mathrm{~mm}$ long with a broad coiled or twisted base and a stiff recurved upper part, becoming erect at maturity, dehiscent at first along the suture, perhaps later from the apex on both sides, the surface pale with a few long fine hairs especially near the suture, the texture leathery, the veins delicate, at c. $60^{\circ}$, the tissue very short and even.

In western Western Australia. Usually in red sand, loam or clay, in damp, often salty, places. Fig. 13.

Selected SPECIMENS (from c. 30 examined): Western Australia: Gascoyne River between Carnarvon \& Jimba Jimba, Gardner 6058, 20 Sep 1941 (PERTH); Wooramel-River, Robinson 1889 (MEL); $67 \mathrm{~km}$ SSE of Meekatharra on the Sandstone road, Chinnock 1037, 14 Sep 1975 (AD); Cue, Fitzgerald, Sep 1903 (NSW); Barnong, Humphries, 28 Sep 1950 (PERTH). 
26. S. villosa J. Black

(J.M. Black 1924b: 319)

Type: South Australia: Glen Ferdinand, Musgrave Ranges, S.A. White, 19 July 1914; holo $\mathrm{AD}$; iso $\mathrm{AD}$.

A spreading, usually low-growing annual or perennial, to c. $20 \mathrm{~cm}$ high, with numerous stems, often with their bases below the soil-surface, from a taproot. Stems mostly $1.5-3 \mathrm{~mm}$ wide, ribbed or angled, with a usually rather dense pubescence, the hairs extremely slender, minutely tubercle-based, mostly c. 0.75 but to $1.5 \mathrm{~mm}$ long, terete, tapering to a fine point, occasionally dark; spreading and basifixed. Leaves $3-8 \mathrm{~cm}$ long, with 7-15 leaflets above an extended petiole, the leaflets obovate, sometimes narrowly so, the pubescence long, fine and spreading, on both surfaces but sometimes only near the margin of the upper surface, the lateral leaflets usually $5-15 \mathrm{~mm}$ long and 2-6 mm wide, the terminal sometimes a little longer and occasionally broader than the upper laterals, but variable, as are the laterals in proportion, the leaflet-apex usually rounded to slightly retuse, with a minute point. Stipules mostly 5-15 mm long, obliquely deltoid-acuminate, often with a very attenuated narrow tip, the outer margin often irregular and occasionally with a lateral tooth, green, not forming an abaxial ridge and with hairs on both surfaces. Racemes $2-25 \mathrm{~cm}$ long with 2-15 or more flowers of differing age but without both buds and fruit on the same raceme. Peduncle (0.5-)1-2 mm wide, with the pulvinus absent, the flowers usually occupying c. $1 / 2$, occasionally $2 / 3$ of its length, strongly ridged, somewhat flattened near the flowers, with dense to sparse, fine, spreading hairs, dark and more dense and antrorse in the upper part. Bracts lanceolate, very narrowly attenuate, $3-5 \mathrm{~mm}$ long. Flowers purple or occasionally pink or white, 7-10 mm long, on pedicels with dark, spreading hairs and 1-3 mm long. Hypanthium short and broad, scarcely contracting at the apex under the fruiting calyx, the bracteoles linear, usually minute. Calyx with the tube c. $1.5 \mathrm{~mm}$ long, obliquely but little and gradually expanding above the hypanthium-top, with short antrorse dark hairs and long spreading white hairs, the lobes narrowly deltoid and very long- attenuate, often about twice the length of the tube, the sinuses rounded and rather broad. Standard 8-11 $\mathrm{mm}$ long and 9-15 $\mathrm{mm}$ wide, tapering rather abruptly to a short broad tapered claw, thickening at the base obscure or absent. Wings 9-11 mm long, narrowly ovoid-oblong, the apex rounded rather obliquely (the lower edge longer), the claw very short, rather narrow, and much curved, the auricle long, narrow, rounded, rather twisted, and recurved. Keel 8$11 \mathrm{~mm}$ long and 3-3.5 mm deep, with the apex narrow, rather acute, expanded at the tip, with the upper margin raised shortly behind the tip and then very shallowly downcurved before rising to the deltoid, backwardly directed auricles, the pouches virtually absent, the claw long, slender, scarcely tapered and straight to slightly recurved. Ovary 4-5 $\mathrm{mm}$ long, somewhat obliquely elliptic, with very long loose, antrorse hairs except near the base where shorter with some reversed and irregular, tapering to the apex and obliquely and suddenly at the base. Ovules numerous. Stipe 1-1.5 mm long, very slender and for the most part glabrous. Style slender, somewhat downcurved at the base and shallowly curved above, laterally flattened and pale but not thickened, not or little tapered, not twisted, the tip obliquely truncate with a short antrorse arc of hairs on the longer side behind a minute narrow apex, the beard sparse and only towards the tip. Fruit 8-15 $\mathrm{mm}$ long and 7-10 $\mathrm{mm}$ wide, suboblong to almost orbicular, much inflated, sometimes a little flattened on the sutural side, with the suture not or somewhat intruded, rounded at the base above a short, very slender stipe-like extension above a $2-2.5 \mathrm{~mm}$ slender stipe, and at the apex broadly rounded behind, or below, the 5-7 mm reflexed style and without a beak, raised to erect at maturity, with long, soft, spreading hairs with minute tubercles at their base, dehiscent at the apex on both sides and often splitting around the circumference, the 
texture very thin but stiff, the veins very delicate and obscure, at c. $90^{\circ}$ from a stout thickened ridge, the tissue strong but not deep, the loculus not closed.

In eremean parts of central and north-western South Australia and in the southern part of the Northern Territory and adjoining part of Western Australia. In red sandy soils, often associated with granite, frequently with Acacia. Fig. 13.

Selected SPECimens (from c. 125 examined): Western Australia: 27 miles [43 km] W of Musgrave Park, George 5190, 20 July 1963 (PERTH). NoRTHERN TERRITORY: Petermann Ranges Reserve, 9 km E of Docker River Crossing, on Ayers Rock road, Henshall 2211, 12 Sep 1978 (NSW, NT); 5 miles [8 km] N of Mt Cavanagh Station, Perry 5487, 12 Sep 1955 (AD, BRI, CANB, K, MEL, NSW, NT). South Australia: Ernabella, Young, 13 July 1943 (BRI, MEL); $15 \mathrm{~km}$ NNW of Mt Eba Homestead, 1.6 km E of Margaret Dam, Chinnock 397, 18 Aug 1973 (AD, NSW).

\section{Group 4}

1 Style-base narrow

2 Stem-hairs basifixed

27. S. rostellata

2* Stem-hairs medifixed or attached above the base

28. S. rotunda

$1^{*}$ Style-base very broad and extending over the ovary-apex

3 Leaflet-apex deeply indented; style-tip not slender and with 2 spaced lines of minute hairs 29. S. gracilis

$3^{*}$ Leaflet-apex rounded or shallowly indented; style-tip narrow and with short stiff hairs on the margins

30. S. pterostylis

\section{S. rostellata A. Lee}

(A.T. Lee 1948: 183)

Type: Western Australia: Mt Magnet, C.A. Gardner 2232, 11 July 1931; holo PERTH; iso $\mathrm{K}$.

A prostrate, probably perennial, plant only a few centimetres high, with a number of stems from the top of a taproot, the stem-bases often below the soil-surface. Stems from less than to a little more than $1 \mathrm{~mm}$ wide, flattened below the nodes, with sparse, minute, elliptic or tapering, turgid or flat, basifixed or subbasifixed and appressed hairs. Leaves 1-5 cm long, with 7-13 leaflets above an extended, often very long, petiole, the leaflets mostly cuneate, with short scattered appressed hairs, sometimes on both surfaces, the lateral leaflets $1-5(-7) \mathrm{mm}$ long and 1-2(-3) $\mathrm{mm}$ wide, the terminal not or scarcely longer, the leaflet-apex usually conspicuously retuse or emarginate, a central point minute or absent. Stipules 1-2 $\mathrm{mm}$ long, the shape variable but usually broad, deltoid or hemispherical and often with irregular margins, those at the same node often uneven, green, with or without an abaxial ridge forming, and with sparse hairs on both surfaces. Racemes $1-5(-10) \mathrm{cm}$ long, with 1-3(-6) flowers of even age. Peduncle up to 0.5 (or almost 1) mm wide, with little, if any, development of a pulvinus, with the flowers near the apex or over the top $1 / 4$ of its length, variably ribbed, glabrous or with sparse hairs, more dense and sometimes dark near the apex. Bracts ovate-lanceolate, c. $1 \mathrm{~mm}$ long. Flowers purple, very variable in size, from 1-8 $\mathrm{mm}$ long, on pedicels with minute turgid dark hairs and 1-2 $\mathrm{mm}$ long. Hypanthium small, with the calyx inflating and covering its apex in the fruit, the bracteoles minute and very broad. Calyx with the tube $1-1.5 \mathrm{~mm}$ long, rather inflated and oblique above the hypanthium-top, and with the sides slightly outcurved, with minute dark hairs, the lobes deltoid, almost as long as the tube, not dissimilar, the sinuses narrow. 
Standard 4-7 $\mathrm{mm}$ long and 4-8 $\mathrm{mm}$ wide, strongly tapered to rounded at the base above a relatively long, broad, tapered claw, with two large vertical thickenings at the base. Wings 3-7 mm long, curved-obovate, the apex broad and shallowly rounded, the claw rather short, broad, much-tapered and curved, the auricle rounded, directed backwards or somewhat erect, and twisted. Keel 4-6 mm long and 1-2 mm deep, narrowly obtuse with the tip narrow and erect, swollen at the apex behind this and with a strong twist well behind, with the upper margin strongly downcurved from the tip and upcurved to the deep and truncate or sloping, i.e. imperceptible, auricles, without pockets, the claw very long, slender, rather tapered and straight. Ovary c. $2 \mathrm{~mm}$ long, ovate-elliptic, glabrous apart from a few minute hairs at the base on the sutural side, tapering to the apex and obliquely and more suddenly tapering at the base. Ovules c. 8, few developing. Stipe c. $1 \mathrm{~mm}$ long, very slender, glabrous. Style slender, virtually untapered for most of its length or broadening a little above the middle before tapering to the apex, laterally flattened and somewhat stiffened in the central region where scarcely curved, terete, unthickened and strongly curved at the base, and near the apex twisted, incurved or inflexed and flattened in the other dimension with minute hairs in 2 rows probably representing the beard but upwardly directed, the beard erratic elsewhere and minute on the edges of a rather flattened area behind the flexible tip. Fruit 6-10 $\mathrm{mm}$ long and 5-8 $\mathrm{mm}$ wide, broad-elliptic to almost orbicular, dorsiventrally compressed but inflated either side of a widely intruded suture, contracted at the base above a very slender stipe less than $1 \mathrm{~mm}$ long, and at the apex behind the $2-3 \mathrm{~mm}$ reflexed style, erect at maturity, splitting into two halves and separating from the stipe, the texture woody, the surface with strong raised acute ridges more raised on the sutural side, the veins at $60^{\circ}-90^{\circ}$, glabrous, the tissue deep and sealing the loculus.

In inland south-western Western Australia. Usually in red sand or clay-loam, often in soakage areas. Fig. 14.

Selected SPecimens (from 28 examined): Western Australia: $26 \mathrm{~km}$ SE of Sandstone, Chinnock 1054, 15 Sep 1973 (AD); Greenough River Flats, Grey, 1869 (MEL); Mt Malcolm, Rodway, Nov 1906 (HO); Leonora, Gardner \& Blackall 356, 5 Aug 1931 (PERTH); Buningonia Soak, Keighery 3108, 14 Aug 1980 (K, PERTH).

\section{S. rotunda J. Thompson, sp. nov.}

Herba exilis prostrata. Foliola c. 7 anguste lanceolato-elliptica. Racemi $1.5-2.5 \mathrm{~cm}$ longi floribus c. $4 \mathrm{~mm}$ longis. Calyx lobis tubum circa aequantibus. Vexillum versus basim non incrassatum. Carina anguste obtusa vel acuta. Stylus interdum latus apice subincurvo vel subinflexo pilis antrorsis. Fructus $7 \mathrm{~mm}$ longus circularis depressus.

TyPe: Western Australia: near Pink Hills, E. Wittwer 1052, 11 Aug 1975; holo PERTH.

A slender prostrate plant probably with several stems and some condensed branching at the nodes; but known from only one specimen. Stems scarcely $1 \mathrm{~mm}$ wide, conspicuously flexuose, terete or slightly angled below the nodes, with spaced hairs, the hairs narrowly elliptic or lanceolate, tapering at both ends, flat or turgid, appressed and medifixed, sometimes asymmetrically. Leaves to $2.5 \mathrm{~cm}$ long with c. 7 leaflets above an extended (in older leaves) petiole, the leaflets narrowly lanceolateelliptic and incurved at the margin, at least when dry, with an appressed pubescence more dense on the lower surface, the lateral leaflets 5-10 mm long and mostly c. 1.5 $\mathrm{mm}$ wide, the terminal slightly longer but often absent, the leaflet-apex obtuse with a minute point. Stipules 1-2 mm long, deltoid, often obliquely, and acute to acuminate, sometimes partly green, widely separated, not forming an abaxial ridge and with spreading hairs on both surfaces. Racemes $1.5-2.5 \mathrm{~cm}$ long, with 1-4 flowers of 
uneven age. Peduncle less than $0.5 \mathrm{~mm}$ wide, without a pulvinus, with the flowers in the top 1/3 or less, terete, with sparse appressed hairs, a few dark, among the flowers. Bracts ovate, less than $1 \mathrm{~mm}$ long. Flowers 'lilac', c. $4 \mathrm{~mm}$ long, on pedicels with minute flat, often dark, hairs, and c. $0.5 \mathrm{~mm}$ long. Hypanthium slender, the bracteoles minute. Calyx with the tube c. $1 \mathrm{~mm}$ long, a little inflated above the hypanthium-top and perhaps contracting above, with scattered hairs, the lobes deltoid and acuminate, approximately as long as the tube, not dissimilar, the sinuses broad. Standard $4 \mathrm{~mm}$ long and as wide, tapering evenly to the base with the tapered claw ill-defined, without basal thickenings. Wings $4 \mathrm{~mm}$ long, curved-oblong, the apex rounded, the claw short, tapered and curved, the auricle deep, deltoid and directed backward. Keel $4 \mathrm{~mm}$ long and $1.5 \mathrm{~mm}$ deep, with the apex narrowly obtuse to acute and neither upturned nor twisted, with the upper surface straight behind an upcurve at the tip, the auricle deeply almost truncate, without pockets, the claw long, a little tapered and straight. Ovary c. $2.5 \mathrm{~mm}$ long, broadly elliptic, with appressed hairs, obliquely contracting at the apex, with the upper part broader, and tapering at the base with the lower part broader. Ovules not seen. Stipe c. $0.75 \mathrm{~mm}$ long, slender, almost glabrous. Style broad and terete at the base where slightly downturned, a little narrower and flattened, but not much tapered, above the base, and less curved above the strong basal curve, the tip terete somewhat tapered and a little incurved or inflexed with a strongly antrorse tuft of hairs across and behind it, the beard only in the apical part. Fruit $7 \mathrm{~mm}$ long, and almost as wide, almost circular, strongly dorsiventrally compressed but a little inflated with the suture broadly intruded, strongly contracted and curved at the base above a stipe c. $0.75 \mathrm{~mm}$ long and contracting, beak-like and upcurved at the apex below the recurved style of a little more than $1 \mathrm{~mm}$, not seen attached but splitting into two halves at maturity (but not separating from the stipe), the surface with spaced appressed hairs, the texture woody, the veins obscure near the centre but probably at c. $30^{\circ}$, the surface with raised veins, two raised as acute ridges on each surface, longer and more raised on the sutural size and midway between the suture and the almost wing-like margin, the tissue very deep and probably sealing the loculus.

Known only from one locality in inland western Western Australia. Said to be in red sandy loam. Fig. 14.

This species is named for its fruit-shape. From the Latin rotundus, round.

\section{S. gracilis Benth.}

(G. Bentham 1864: 220)

TyPe: Western Australia: Murchison R., Oldfield; K, MEL, PERTH.

A prostrate or low-growing, perhaps perennial, plant to 30 or $40 \mathrm{~cm}$ high, with several stems from a taproot, their bases sometimes below the soil-surface. Stems 1$2 \mathrm{~mm}$ wide, somewhat flattened below the nodes, glabrous or with a few minute, broad, turgid, basifixed or subbasifixed and appressed hairs. Leaves $1.5-7 \mathrm{~cm}$ long, with up to 15 leaflets above a very long petiole, the leaflets cuneate to narrow-oblong, usually with a few appressed hairs on the lower margin, the lateral leaflets 1-8 mm long and 1-3 mm wide, the terminal variable in proportion, the leaflet-apex deeply retuse or emarginate. Stipules of variable length, often 3-4 $\mathrm{mm}$ long, variable in shape, often broadly ovate or deltoid with lateral teeth on both margins, members of a pair often markedly different in size, green, occasionally one of a pair scarious, not forming an abaxial ridge and usually with a few hairs on both surfaces. Racemes 6-12 cm long, with 1-4 flowers of almost even age. Peduncle $0.5-1 \mathrm{~mm}$ wide, with some development of a pulvinus, with flowers in the top 1-2 $\mathrm{cm}$ of the peduncle, ribbed, 
with sparse hairs. Bracts ovate, c. $1.5 \mathrm{~mm}$ long. Flowers purple, $5-7(-10) \mathrm{mm}$ long, on pedicels with minute, turgid, often dark, hairs and 1-3 mm long. Hypanthium very short and broad, not contracting at the apex, though sometimes narrow under the fruiting calyx, the bracteoles minute. Calyx with the tube c. $2 \mathrm{~mm}$ long, a little inflated and oblique above the hypanthium-top with the sides slightly outcurved, glabrous or with a few hairs on the lobes, the lobes deltoid, shorter than the tube, the sinuses narrow. Standard very variable in size, $5-12 \mathrm{~mm}$ long and as wide to almost twice as wide, contracted to a slender claw, with two horizontal calli or rather amorphous thickenings at the base. Wings 5-9 mm long, curved, somewhat deltoid-oblong, i.e. the apex narrower than the base, the apex rounded, the claw long, very slender and curved, the auricle very deep and cuneate or rounded at the top. Keel 5-8 mm long and 2-3 $\mathrm{mm}$ deep, with the apex obtuse, swollen below the slightly incurved tip and strongly twisted behind this, with the upper surface curved slightly downward behind the rounded tip and upward to the rather deep and truncate auricles, and without pockets, the claw very long, untapered and straight or slightly recurved. Ovary c. $2 \mathrm{~mm}$ long, broadly elliptic, glabrous except for dense reversed hairs on the lower sutural side, a little contracted near the apex where the style extends over the upper surface, and obliquely and abruptly tapering at the base. Ovules c. 8, few developing. Stipe c. $1 \mathrm{~mm}$ or a little more long, slender, slightly curved, glabrous or with some hairs on the upper margin. Style very broad-based and expanding a little before gradually tapering in the lower part, the apical $1 / 2$ or more little tapered to behind an incurved or inflexed tip, all laterally flattened and twisted and a little stiffened and pale, the tip not very slender and with minute erect hairs, in two lines, behind it, the beard sparse except in the upper part where short and antrorse. Fruit 6-10 $\mathrm{mm}$ long and 5-9 mm wide, broad-elliptic to slightly broader than long, strongly dorsiventrally compressed but a little inflated either side of the broadly intruded suture, contracted at the base above a slender c. $1 \mathrm{~mm}$ stipe and at the apex below the broad style-base bearing the c. $4 \mathrm{~mm}$ long, recurved and twisted style, raised at maturity, splitting into two halves and separating from the stipe, glabrous except for hairs near the base on the sutural side, the texture very woody, the surface with strong, acutely raised reticulation forming ridges, one ridge somewhat variably forming a wing on each side often so wide as to make the apex and base appear retuse, the veins at $90^{\circ}$, the tissue strong and closing the loculus.

In inland Western Australia. In various soils, in moist places. Fig. 14.

Selected SPECIMENS (from 12 examined): WeStern Australia: 1.5 miles [2.5 km] W of Gascoyne Junction, Ashby 4771, 30 June 1975 (AD); Jimba Jimba, Demarz 3832, 18 Aug 1972 (PERTH); Boolardy, Humphries, 21 Sep 1950 (PERTH); Wooleen, Yandi Paddock, Humphries, 23 Sep 1950 (PERTH); 29 miles [46 km] W of Mt Magnet, George 7970, 11 Sep 1966 (PERTH).

\section{S. pterostylis (DC.) Bakh. f.}

(R.C. Bakhuizen van de Brink jnr. in Steenis \& Bakhuizen 1967: 395)

BASIONYM: Astragalus pterostylis DC. (A.P. de Candolle 1825b: 294).

TYPE: v.s., in ins. Timor et Novae-Hollandiae ora orientale; holo G, n.v., photo NSW.

S. occidentalis F. Muell. (F. Mueller 1862: 46). TYPE: WESTERN Australia: Nichol Bay, Pemberton Walcott; holo MEL; iso K, (fragment NSW).

Diplolobium walcottii F. Muell. (F. Mueller 1863: 489). TYPE: WeSTERN Australia: Nichol Bay, Pemberton Walcott; holo MEL; iso K.

A low-growing or prostrate perennial, often to $30-40 \mathrm{~cm}$ high, with numerous stems from the top of a taproot. Stems (1-)3(-more than 5) $\mathrm{mm}$ wide, often conspicuously 
flexuose, somewhat flattened or ridged below the nodes, with sparse hairs, the hairs c. $0.5 \mathrm{~mm}$ or less long, usually tapering to the apex or rather lanceolate-elliptic, flat or turgid, appressed and basifixed or subbasifixed. Leaves very variable in size but mostly 4-12 cm long, with (7-)11-19(-27) leaflets above a usually somewhat extended petiole, the leaflets broad-elliptic to narrowly obovate, almost glabrous or with an appressed pubescence on the lower surface, the lateral leaflets $5-30 \mathrm{~mm}$ long and 2-10(15) $\mathrm{mm}$ wide, the terminal usually somewhat longer than the shorter upper laterals but often irregular, the leaflet-apex rounded to truncate or shallowly emarginate, with a minute point. Stipules from c. 2 to c. $10 \mathrm{~mm}$ long, broadly and obliquely acuminate-deltoid, and often with long acute lobes on both sides, green, widely separated, not forming an abaxial ridge, and usually with a few hairs on both surfaces. Racemes 5-30 cm long, with 5 to more than 30 flowers of somewhat uneven age (but without buds and young fruit on the same raceme). Peduncle 1-3 mm wide, without a pulvinus, with flowers over $1 / 2$ to almost the whole, conspicuously ribbed, sparsely pubescent, the hairs often dark in the upper part. Bracts ovate, c. $2 \mathrm{~mm}$ long. Flowers purple, $7-10 \mathrm{~mm}$ long, on glabrous or pubescent pedicels, often with dark hairs, and 2-3 mm long. Hypanthium short and broad with the calyx inflating and covering its apex in the fruit, the bracteoles minute. Calyx with the tube c. $2 \mathrm{~mm}$ long, inflated at the base above the hypanthium and slightly outcurved above, glabrous or somewhat pubescent, the lobes deltoid, often narrowly, and often acuminate, equal to or shorter than the tube, not very dissimilar, the sinuses narrow. Standard 9-12 $\mathrm{mm}$ long and 10-14 mm wide, abruptly contracting or rounded above a rather long slender claw with two large close vertical calli above it. Wings 8-10 mm long, narrowly obovoid and somewhat curved, the apex shortly and broadly obtuse, the claw long, slender and somewhat curved, the auricle deep, deltoid and rather erect. Keel 7-9 mm long and 2.5-3.5 mm deep, strongly twisted well behind the apex, with the apex obtuse and the tip raised or retracted and twisted, slightly swollen behind the apex, with the upper margin shortly upcurved at the apex and then downcurved, often strongly, and raised to the short rounded auricles, without pockets, the claw very long, tapered and straight. Ovary 3-4 mm long, ovate, glabrous except for a dense tuft of retrorse hairs at the base on the sutural side, with a slight taper to the apex obscured by the surrounding style-base, and rather abruptly contracted from the top at the base. Ovules c. 8, few developing. Stipe 1-1.5 mm long, slender, a little curved, with hairs along the upper margin or glabrous. Style (Fig. 6) with its base very broad and surrounding the ovary-apex, a little expanding and descending before tapering abruptly and then gradually to the fine tip, strongly laterally flattened and twisted, stiff and pale, the tip of thinner texture, narrow and flattened in the other dimension, variably incurved or inflexed, the beard variable elsewhere but short, stiff and antrorse on a narrowly flattened (in the other dimension) base in the upper part and on the tip. Fruit 6-12 mm long and 5-8 $\mathrm{mm}$ wide, oblong to almost spherical, usually somewhat inflated either side of a broadly indented suture, strongly dorsiventrally compressed, contracted abruptly at the base above a slender c. $1 \mathrm{~mm}$ stipe and the apex below a minute erect beak bearing the recurved or coiled c. $7 \mathrm{~mm}$ style or its broad base, usually raised or erect at maturity, splitting into two halves and separating from the stipe, glabrous except for hairs near the base of the suture, the texture very woody, the surface with strong raised acute ridges, the veins at $60^{\circ}$ or more, the tissue deep and sealing the loculus.

In coastal and inland areas of western and north-western Western Australia. From coastal sandhills to red claypans, often in calcareous and/or salty soils. Fig. 14.

Selected specimens (from c. 110 examined): Western Australia: W of Withnel Bay, Burrup Peninsula, Keneally 7288, 22 July 1980 (PERTH); 15 miles [24 km] SE of Berringarra, Speck 681, 6 Sep 1957 (CANB, NSW); Northwest Highway, N of Carnarvon, Gittins 1517, Aug 1967 (BRI, 
NSW, PERTH); 10 miles [16 km] E of Carnarvon, Burbidge 6495, 3 Sep 1959 (AD, BRI, CANB, NSW); near Murchison River, Beard 4333, 20 Aug 1965 (PERTH).

\section{Group 5}

1 Fruit almost straight and, in general, ovoid

31. S. paradoxa

$1^{*}$ Fruit strongly curved and, in general, ellipsoid

2 Leaflets 1-7, 10-50 $\mathrm{mm}$ long or more

32. S. cyclocarpa

2* Leaflets $9-13,1-7 \mathrm{~mm}$ long

33. S. halophila

\section{S. paradoxa W. Fitzg.}

(W.V. Fitzgerald 1904: 5)

TYPe: Western Australia: Nannine, W.V. Fitzgerald 130, Sep 1903; holo NSW; dupl. said to be at $K$ but not found there.

A prostrate or ascending perennial, or perhaps annual, plant, rarely reaching $20 \mathrm{~cm}$ high, with a number of stems from the top of a taproot, occasionally with branches below the soil-surface. Stems (0.5-)2-4 mm wide, terete or somewhat flattened or ridged below the nodes, with sparse, minute, flat or turgid, appressed, often loosely, and basifixed hairs. Leaves $1-12 \mathrm{~cm}$ long, with 1-9 leaflets above a usually very short petiole, the leaflets mostly broadly obovate, usually with a minute appressed pubescence often dense on the lower surface and usually absent from the upper, the lateral leaflets from minute to c. $25 \mathrm{~mm}$ long and to c. $15 \mathrm{~mm}$ wide, all leaflets largest on unifoliolate leaves and smallest on the upper part of the plant, the terminal leaflet usually the largest but variable in the amount of difference, often very large in unifoliolate leaves, reaching $40 \times 30 \mathrm{~mm}$, the leaflet-apex usually retuse or broadly emarginate. Stipules 2-7 mm long, from obliquely broad-deltoid and acuminate to almost semicircular or with a broad rounded basal extension, the outer margin uneven or obscurely toothed, green, forming an abaxial ridge and pubescent on both surfaces. Racemes 5-25 cm long with 2-20 flowers of uneven age (but not with both buds and fruit on the same raceme). Peduncle $0.5-3 \mathrm{~mm}$ wide, the pulvinus not developed, with flowers usually occupying $1 / 2$ or less of its length, ribbed, with very sparse hairs or dense hairs near the flowers. Bracts ovate, 1-1.5 mm long. Flowers purple, to pink or white, 7-8 mm long, on pubescent pedicels, often with dark hairs, and c. 2 $\mathrm{mm}$ long. Hypanthium short, tending to contract at the apex under the fruiting calyx, the bracteoles usually very small, often broad. Calyx with the tube c. $1.5 \mathrm{~mm}$ long, variably expanding above the hypanthium-top, with small appressed, often dark, hairs, the lobes deltoid, shorter than the tube, not dissimilar, the sinuses broad above but narrowly rounded at the base. Standard $8-10 \mathrm{~mm}$ long and to c. $12 \mathrm{~mm}$ wide, rather shortly tapering to a rather long, tapered claw, concave at its apex, and with two calli or some indistinct thickening above. Wings 7-8 $\mathrm{mm}$ long, oblong, with the apex very shortly obtuse, the claw slender, short, curved and slightly tapered, the auricle deep, rounded-deltoid and directed backward. Keel 7-8 mm long and 3-4 mm deep, somewhat acute with a broad tip projecting very slightly forward, with the upper margin curved upward at the tip then turning downward for c. $1 / 3$ of the distance before rising gradually to the deep, well rounded and backward-facing auricles, with small folds near its base, the claw short, slender, slightly tapered and straight or a little recurved. Ovary c. $4 \mathrm{~mm}$ long, obliquely ovoid, minutely appressedpubescent, or with hairs restricted to the suture, the apex long and obliquely tapered, the base shortly contracting from the top. Ovules c. 8 . Stipe c. $0.5 \mathrm{~mm}$ long, slender, 
curved, glabrous or with a few hairs. Style (Fig. 6) rather slender, with the base scarcely distinguishable from the narrow ovary-apex and somewhat downcurved, tapering only near the base and more curved there before, above this, becoming straight-sided or slightly expanding and then contracting to the tip, this section slightly thickened and laterally flattened, not twisted, only slightly curving to an oblique almost truncate apex bearing a very slender incurved extension with a dense arc of antrorse hairs behind it, the beard only in the upper part where antrorse. Fruit mostly 10-15 mm long and of half to equal width, in general ovoid, but variable, little, if at all curved, the main body usually dorsally compressed and somewhat inflated, with the suture intruding, contracting at the base above the c. $1 \mathrm{~mm}$ stipe and at the apex behind a minute, broad, often rather upturned, beak behind the 3-4 $\mathrm{mm}$ recurving style, variably raised at maturity, dehiscent at the suture, perhaps ultimately breaking in $1 / 2$, sometimes breaking from the stipe, with scattered minute hairs, the texture almost woody, the surface with c. 6 undulating deep and rather acute, longitudinal ridges, with some of the undulations forming boss-like peaks, the veins almost invisible, perhaps at $30^{\circ}-45^{\circ}$, the tissue deep and closing the loculus.

In inland Western Australia. On margins of salt lakes and on salt flats. Fig. 15.

Selected specimens (from c. 20 examined): Western Australia: $32 \mathrm{~km}$ E of Wiluna, Toelken 6103, 12 Sep 1979 (AD); Lake Way, Craven 5088, 24 Apr 1978 (CANB); Lake Annean, Speck 1117, 31 July 1958 (CANB, NSW); Nambi H.S., $65 \mathrm{~km}$ NNE of Leonora, Wilson 7491, 29 Aug 1968 (PERTH); 6 miles [9.5 km] N of Bulga Downs, Demarz 5229, 25 Sep 1974 (PERTH).

\section{S. cyclocarpa F. Muell.}

(F. Mueller 1892: 136)

TYPE: NoRTHERn TerRITORY: MacDonnell Range, W.F. Schwarz, 1889; holo MEL; iso K.

A prostrate or low-growing, perhaps annual, plant less than $15 \mathrm{~cm}$ high, with several stems from the top of a taproot. Stems $1.5-3 \mathrm{~mm}$ wide, often strongly ribbed, flattened or angled from below the nodes, with sparse, broad, flat or turgid, usually minute and appressed, basifixed hairs. Leaves $1.5(-7) \mathrm{cm}$ long, with 1-7 leaflets above an extended petiole, the leaflets usually obovate to somewhat trapeziform, glabrous or with a minute appressed pubescence especially on the lower surface and upper leaves, the lateral leaflets $10-50(-70) \mathrm{mm}$ long and 5-30 mm wide, and all leaflets largest on unifoliolate leaves and smaller on the upper part of the plant, the terminal leaflet larger than the upper, and usually all, laterals, the leaflet-apex usually retuse but sometimes rounded, often with a minute point. Stipules $2-7 \mathrm{~mm}$ long, the smaller broadly and obliquely deltoid but the larger with a broad and rounded base and appearing auricled, and very oblique, the outer margin irregular but not lobed, the tip sometimes attenuate, green, not forming an abaxial ridge and with a few hairs on both surfaces. Racemes 10 to more than $15 \mathrm{~cm}$ long, with 4-16 flowers of somewhat dissimilar age (but not with both buds and young fruit on the same raceme). Peduncle $0.5-1.5 \mathrm{~mm}$ wide, with a pulvinus variable in its development, with flowers usually occupying $1 / 2$ or even more of its length, somewhat ribbed or flattened near the flowers, with scattered, minute, turgid, appressed hairs. Bracts ovate, c. $1 \mathrm{~mm}$ long. Flowers purple, $8-10 \mathrm{~mm}$ long, on pedicels with minute turgid often dark hairs and 1$3 \mathrm{~mm}$ long. Hypanthium short, somewhat contracted at the apex under the fruiting calyx, the bracteoles minute. Calyx with the tube c. $2 \mathrm{~mm}$ long, narrowly expanded above the hypanthium-top, almost glabrous, with a few scattered hairs, the lobes deltoid-acuminate, obviously shorter than the tube, the sinuses rather broad above but often narrowly rounded or even acute at the base. Standard 8-10 $\mathrm{mm}$ long and as wide, or a little wider, suddenly tapering or rounded above a slender tapered claw, 
with two distinct small, almost vertical calli, and a concave area above. Wings c. $7 \mathrm{~mm}$ long, oblong, with the apex very shortly obtuse, the claw rather long, slender, curved and slightly tapered, the auricle rather deep, short, rounded and backwardly directed. Keel 7.5-8 mm long and 2.5-3 mm wide, with the apex somewhat acute with a narrow forward-projecting tip, with the upper margin almost straight but slightly raised behind the tip and for some distance in front of the rather large, rounded and backward-facing auricles, with a fold at the base of the auricles and an indentation at the base behind the short slender slightly tapered, slightly recurved claw. Ovary c. 4 $\mathrm{mm}$ long, elliptic, curved, with minute appressed hairs, the apex a little tapered, to behind a narrow tapered apex, the base much- tapered to a narrow tapering almost stipe-like region above the stipe. Ovules numerous. Stipe c. $1 \mathrm{~mm}$ long, slender, curved, glabrous. Style rather slender with the base like the broad ovary-apex and downcurved, tapering to a narrow area, often somewhat twisted and usually strongly curved there, then slightly expanding to an untapered, or somewhat expanded and then contracted, only very slightly curved, region that is not, or sometimes a little, thickened, with the apex obliquely truncate behind a very short to somewhat extended inflexed tip with a stiff arc of erect or antrorse short hairs behind it with hairs extending onto the tip, the beard short and restricted to the upper part. Fruit (Fig. 7) c. 15-20 mm long and $5 \mathrm{~mm}$ deep and, though somewhat flattened on the upper surface, not or scarcely dorsiventrally compressed, basically somewhat elliptic but very strongly curved to more or less than $3 / 4$ of a circle, inflated with the suture only a little intruded, contracted at the base above a narrow stipe-like section and a short, narrow, c. $1 \mathrm{~mm}$, stipe and tapering abruptly and obliquely at the apex behind a straight, narrow, tapered beaklike portion that merges with the c. $3 \mathrm{~mm}$ recurved style, raised at maturity, dehiscent at the suture, with scattered minute appressed hairs, the texture woody, the surface with strongly and acutely raised ridges, the veins at c. $30^{\circ}$, the tissue very deep and closing the loculus.

In the southern half of the Northern Territory, with an outlier in northern Western Australia. On margins of salt lakes. Fig. 15.

Selected specimens (from c. 10 examined): Western Australia: $18^{\circ}, 126^{\circ} 16^{\prime}$, A. Forrest, 1879 (MEL). NORTHERN TERRITORY: eastern arm of Lake White, Maconochie 933, 2 Aug 1970 (NSW, NT); Mt Wedge Station, Henry 384, 20 Jan 1972 (AD, BRI, NSW, NT); Napperby Salt Lake, Dunlop 2350, 12 Jan 1972 (MEL, NSW, NT, PERTH); Lake Neale, Maconochie 1892, 28 Aug 1973 (BRI, CBG, NT).

\section{S. halophila J. Thompson, sp. nov.}

Herba plerumque prostrata forsan annua usque ad c. $15 \mathrm{~cm}$ alta. Foliola 9-13 ovata usque ad late cuneata vel obcordata. Racemi $1-15 \mathrm{~cm}$ longi floribus $6-8 \mathrm{~mm}$ longis. Calyx lobis tubo brevioribus. Vexillum versus basim concavum lineis crassis. Carina anguste obtusa vel late acuta. Stylus interdum latus apice inflexo vel geniculato pilis antrorsis. Fructus c. $15 \mathrm{~mm}$ longus $7 \mathrm{~mm}$ latus ellipticus valde curvatus.

TYPE: Western Australia: Mt Sir Samuel, near Lawlers, C.A. Gardner 2427, 26 July 1931; holo PERTH; iso K.

A prostrate or occasionally ascending, perhaps annual, plant to c. $15 \mathrm{~cm}$ high, with a number of stems from a small taproot. Stems $0.5-1.5 \mathrm{~mm}$ wide, somewhat ridged or flattened below the nodes, with scattered minute, flat or turgid, elliptic, basifixed and appressed hairs. Leaves from less than 1 to $\mathrm{c.} 8 \mathrm{~cm}$ long, with 9-13 leaflets above a short to well-extended petiole, the leaflets ovate to broadly cuneate or obcordate, pubescent but with the hairs fewer on the upper surface, the lateral leaflets 1-7 mm long and 1-5 mm wide, variable on and between plants, the leaflet-apex usually 
retuse or emarginate, with a small point. Stipules $1-4 \mathrm{~mm}$ long, broadly and obliquely deltoid, with a broad rounded basal extension, a variable extension of the acuminate tip and often with teeth on the outer margin, green, not forming an abaxial ridge and pubescent on both surfaces, densely so on the outer. Racemes 1-15 cm long, with 29 flowers of slightly uneven age. Peduncle from less than 0.5 to $1.5 \mathrm{~mm}$ wide, without a pulvinus, with flowers often in the upper $1-2 \mathrm{~cm}$ but frequently extending further, even up to $1 / 2$ the peduncle-length, somewhat ribbed, often flattened near the flowers, with sparse minute hairs, occasionally dark, in the upper part. Bracts broadovate, often toothed, c. $1 \mathrm{~mm}$ long. Flowers purple, 6-8 $\mathrm{mm}$ long, usually on dark, pubescent pedicels 1-3 mm long. Hypanthium long or short, scarcely contracted at the apex under the fruiting calyx, the bracteoles often rather large and broad. Calyx with the tube 1.5-2 mm long, somewhat obliquely inflated above the hypanthium-top and a little contracted below the lobes, sparsely pubescent with minute hairs or glabrous, the lobes deltoid and shorter than the tube, the sinuses usually broadly rounded. Standard 6-9 $\mathrm{mm}$ long and 7-9 $\mathrm{mm}$ wide, raised tardily, tapering or contracting to a long tapered claw concave at its apex and with two large or small vertical thickenings above. Wings 6-8 $\mathrm{mm}$ long, ovoid-oblong, the apex broadly and very shortly obtuse, the claw rather long, slender, tapered and curved, the auricle very deep and rounded, and directed backward. Keel 5-7.5 mm long and 1.5-3.5 mm deep, narrowly obtuse to broadly acute, the tip rounded, with the upper margin a little raised as a short curve near the tip, then almost straight to the deep shortly rounded and backwardly directed auricles, with a slight fold near the base, the claw rather long, slender, slightly tapered and straight. Ovary 3-4 mm long, narrowly elliptic, curved, with minute hairs, the apex long-tapering, the base tapering rather variably and usually obliquely. Ovules numerous. Stipe c. $0.5 \mathrm{~mm}$ long, curved, glabrous. Style slender, in the lower c. 1/3 tapering from the narrow downcurved ovary-tip, and slightly curved or straight, then strongly curved, the upper part very slightly tapered, laterally flattened, somewhat thickened and a little twisted, the tip narrow, rounded and bearing a short antrorse arc of hairs behind a slightly, to much, extended slender inflexed, often geniculate, segment, the beard often over much of the length but sparse, sometimes dense in the upper part, occasionally on the tip. Fruit c. $15 \mathrm{~mm}$ long and $7 \mathrm{~mm}$ wide, in general elliptic, somewhat dorsally compressed and strongly curved, inflated with the suture well intruded, contracted at the base to a very short narrow tapered stipelike section above the short, c. $1 \mathrm{~mm}$, stipe and at the apex shortly tapered to an upturned beak, of variable length, merging into the base of the c. $4 \mathrm{~mm}$ style, probably raised at maturity, dehiscence seen only at the suture, breaking, at least sometimes, from the stipe, with scattered minute hairs, the texture almost woody, the surface with acute undulating ridges angled from the centre back to the sutural side, those towards the base deeper, the veins at $60^{\circ}-\mathrm{c} .90^{\circ}$, the tissue very deep and closing or folded within the loculus.

In inland Western Australia. On salt flats. Fig. 15.

This species is named for its habitat. From the latinised Greek halophilus, salt-loving.

Selected sPeCimens (from 11 examined): Western Australta: near Lake Carnegie, Fairall 2104, 29 July 1966 (PERTH); 'The Boats', c. $27 \mathrm{~km}$ SW of Laverton on Leonora road, Forbes 1534, 9 Oct 1983 (MEL); between Menzies \& Mulline, Blackall 4121, 14 Sep 1989 (PERTH); Broad Arrow, N of Kalgoorlie, Erickson, July 1952 (MEL); 24 km N of Kalgoorlie, Woolcock 2222, 10 Aug 1985 (CBG). 


\section{Group 6}

1 Peduncle with a distinct, dark pulvinus

34. S. dictyocarpa

$1^{*}$ Peduncle with the pulvinus difficult to distinguish, or absent

2 Wings somewhat crescent-shaped and deep in the centre, i.e. strongly curved and with a large obtuse apical extension

35. S. campylantha

2* Wings not as above

3 Stipules mostly more than $5 \mathrm{~mm}$ long or, if shorter then broad and leaf-like; leaves with more than 3 leaflets

4 Stipules not or scarcely toothed

5 Style $2-3 \mathrm{~mm}$ long; fruit-veins at $30^{\circ}$

36. S. kingii

$5^{*}$ Style more than $4 \mathrm{~mm}$ long; fruit-veins at $30-90^{\circ}$

6 Fruit veins at $30^{\circ}$; bracteoles conspicuous

37. S. viridis

$6^{*}$ Fruit veins at $60-90^{\circ}$; bracteoles minute

7 Stems with sparse minute hairs; keel not much longer than the wings

38. S. perlonga

$7^{*}$ Stems pubescent with hairs mostly c. $0.5 \mathrm{~mm}$ long; keel much longer than the wings

39. S. longicarinata

$4^{*}$ Stipules conspicuously toothed

8 Flowers $12 \mathrm{~mm}$ long or more

41. S. tanamiensi

$8 *$ Flowers $8 \mathrm{~mm}$ long or less

42. S. laciniata

$3^{*}$ Stipules $5 \mathrm{~mm}$ long or less, leaves with $1-3(-5)$ leaflets

40. S. unifoliolata

\section{S. dictyocarpa J. Black}

(J.M. Black 1930: 60)

TYre: SOUTH Australia: Bitter Well, Coondambo, J.B. Cleland, 29 Oct 1929; holo AD; iso K.

A small erect or ascending perennial to $c .15 \mathrm{~cm}$ high, with several stems, their bases below ground, and a taproot. Stems $1-1.5 \mathrm{~mm}$ wide, rather flattened and strongly ridged, gradually expanding to the nodes, virtually glabrous, the few hairs minute, relatively broad and tapering to the apex, appressed, rather turgid and subbasifixed. Leaves 2-4 cm long, with 3-7 leaflets above a variably extended petiole, the leaflets elliptic-obovate, with sparse minute turgid basifixed hairs on both surfaces or glabrous, the lateral leaflets $5-15 \mathrm{~mm}$ long and 2-5 mm wide, the terminal leaflet somewhat longer, the leaflet-apex rounded to retuse, with a point obscure or absent. Stipules 2-4 mm long, deltoid-acuminate, pale and scarious to green, their base broad or narrow, not forming an abaxial ridge and with hairs on the margin. Racemes 2.5-12 $\mathrm{cm}$ long, with 2-8 flowers of dissimilar age. Peduncle $1 \mathrm{~mm}$ or less in width, ribbed strongly, with a distinct dark pulvinus, with flowers in the upper half, with sparse flat hairs, more dense and dark in the upper part. Bracts ovate to narrow-ovate, 1-2 $\mathrm{mm}$ long. Flowers purple, c. $8 \mathrm{~mm}$ long, on dark and densely pubescent pedicels $2-4$ $\mathrm{mm}$ long. Hypanthium rather broad at the top but narrow-based, tending to contract under the fruiting calyx, the bracteoles minute. Calyx with the tube c. $1.5 \mathrm{~mm}$ long, 
much inflated and rather pale above the hypanthium-top, with a slight contraction under the lobes, glabrous or with scattered hairs, the lobes mostly broadly lanceolate and broadly acute, much longer than the tube, the sinuses very narrow (from the broad lobes) and narrowly rounded at the base. Standard c. $10 \mathrm{~mm}$ long and a little less in width, contracting to a long broad tapered claw, with a restricted thickening at the top of the claw and a concave area above it. Wings c. $8 \mathrm{~mm}$ long, narrowly obovate-oblong, the apex broadly expanded and obtuse, the claw not very long, strongly, curved, slender and little tapered, the auricle large, rounded-deltoid and raised. Keel c. $8 \mathrm{~mm}$ long and $3 \mathrm{~mm}$ deep, obtuse, the rather acute to obtuse tip sometimes a little inside the end, with the apex with a slight lateral twist, with the upper margin rather strongly down-curved from behind the tip to the large raised rounded-deltoid auricle, with the pockets long and shallow, the claw long, strongly tapered, rather slender and straight. Ovary c. $4 \mathrm{~mm}$ long, obliquely ovate-oblong, glabrous or with a few hairs along the suture, the apex shortly and obliquely tapered, with a slender beak surrounded by style-tissue, and somewhat downturned, the base obliquely rounded and downcurved. Ovules numerous. Stipe c. $0.5 \mathrm{~mm}$ long, rather stout, glabrous. Style with the broad base surrounding the ovary-tip and strongly tapered then slender and gradually tapering to a long, usually inflexed, straight or curved, tapered tip, all laterally flattened and rather evenly curved, and above the base pale and stiffened with a strong twist, the beard sparse below but long and dense in the upper part and on the tip. Fruit 10-15 mm long and 4-6 mm wide, elliptic or broader above or below the middle, a little curved, inflated with the suture little indented, somewhat dorsiventrally compressed, at the base tapering shortly to a very stout stipe $1 \mathrm{~mm}$ long, at the apex tapering or obtuse with a strongly laterally flattened upcurved beak of the narrowed ovary-apex surrounded by the broad base of the c. $5 \mathrm{~mm}$ style, raised to above the horizontal, perhaps further, glabrous or with sparse hairs along the suture, the dehiscence not seen, the texture leathery, the surface with a raised reticulate pattern, the veins obtusely raised by scarcely raised along the suture, at $\left(45^{\circ}-\right) 60^{\circ}$, the tissue very deep and sealing the loculus.

In central South Australia. Habitat not known. Fig. 16.

SPECIMENS EXAMINED: SOUTH Australia: Tarcoola, Deland, June 1954 (AD).

\section{S. campylantha F. Muell.}

(F. Muell. 1859b: 6)

TyPe: South Australia/ QueENSLAND: on the plains along Cooper's River, A.C. Gregory; holo MEL; dupl. said to be at $\mathrm{K}$ but not found there.

S. fragilis Bailey (F.M. Bailey 1910: 286). TYPE: QuEENSLAND: Georgina River, E.W. Bick 92, Nov 1910; holo BRI.

A low-growing perennial rarely more than $2.5 \mathrm{~mm}$ high, with stems arising in clusters from a complicated underground system, their bases often branched below the soil-surface. Stems mostly $1.5-2.5 \mathrm{~mm}$ wide, strongly ridged, often very gradually expanding to the node, almost glabrous, the few hairs minute, somewhat flattened, narrow and tapering to the apex, loose or rather appressed, antrorse and basifixed. Leaves mostly 3-6 cm long, with 1-7 leaflets, the petiole not very long, the leaflets mostly narrow-lanceolate to -elliptic, glabrous or with a few scattered hairs, the lateral leaflets mostly $10-40 \mathrm{~mm}$ long and 1-5 mm wide, the terminal usually much longer, the leaflet-apex usually long-tapering and with a conspicuous, often recurved, point; occasionally, at the base of the plant, the leaflets obovate and the apex obtuse. Stipules very variable, 1-15 mm long, narrowly linear-deltoid or -elliptic, often rather 
unequal within the pair, sometimes with an acute lateral tooth, green, forming an indistinct abaxial ridge or with a row of hairs, and with a few hairs on the margins or outer surface. Racemes 5-10(-20) cm long, with 2-10(-20) flowers of slightly uneven age. Peduncle from less than 0.5 to $3 \mathrm{~mm}$ wide, with a pulvinus not or scarcely distinguishable, with flowers over $1 / 2$ or less of the length, strongly ridged or angled, glabrous or almost so. Bracts ovate-lanceolate, c. $1 \mathrm{~mm}$ long. Flowers pink to purple, usually $6-10 \mathrm{~mm}$ long, on minutely pubescent pedicels c. $3 \mathrm{~mm}$ long. Hypanthium short and tapering, little if at all contracting under the fruiting calyx, the bracteoles small and narrow. Calyx with the tube c. $2 \mathrm{~mm}$ long, much-expanded above the hypanthium, glabrous, the lobes usually deltoid with long acuminate tips and usually reflexed, about as long as the tube, the sinuses very broad and rounded. Standard 5-10 $\mathrm{mm}$ long and 10-15 mm broad, broad-based and incurved to a short littletapered claw, with an amorphous strongly thickened area above the claw. Wings 7$11 \mathrm{~mm}$ long, somewhat crescent-shaped and deep at the centre, i.e. strongly curved with a very large obtuse extension of the apex from the top, and a deep fold in the central region well above the claw, the claw short, broad and curved, the auricle erect to recurved, folded and rounded. Keel 7-10 $\mathrm{mm}$ long and c. $4 \mathrm{~mm}$ deep, very obtuse with the broad beak-like tip erect, with a distinct sideways twist near the centre, with the upper margin crumpled after sloping from behind the broad raised tip, and slightly raised in front of the deep rounded auricles, with the pockets large, the claw rather long and tapering in the upper part. Ovary $3-5 \mathrm{~mm}$ long, oblong, glabrous or with a short pubescence often only in the lower part, untapered at the apex below the broad style-base and abruptly, a little and obliquely, tapered at the base. Ovules numerous. Stipe 0-0.5 mm long, broad, glabrous. Style much expanded at the base then contracting with an even taper to the tip, strongly laterally compressed, pale, stiffened over the whole length to behind the tip, much curved, especially near the base, and strongly twisted above the base, towards the tip strongly flattened in the other dimension with the tip broad flat and tapering, and unthickened and usually incurved or inflexed, the beard short dense or antrorse, variable in extent, usually confined to tip and the flattened area behind the tip. Fruit 20-45 mm long and 6-7 $\mathrm{mm}$ wide, elliptic, slightly curved, inflated either side of a variably intruded suture so that sometimes dorsiventrally compressed, long-tapering to a narrow stipe-like section above an, often negligible, stipe, and gradually tapering to, or shortly rounded behind, the apex that bears the strongly recurved style c. $6 \mathrm{~mm}$ long, often erect at maturity, the dehiscence not seen, with or without a short closely appressed pubescence, the texture thin and rather softly leathery, the surface smooth with fine veins at $c .30^{\circ}$, the tissue quite deep and folded inside the closed loculus.

Widespread in Queensland, the southern part of the Northern Territory, northern South Australia and north-western New South Wales, and also in northern Western Australia. In heavy red or black soils, in depressions and along creek-lines. Fig. 16.

SELECTED SPECIMENS (from c. 380 examined): WESTERN AusTRALIA: Liveringa Station, Lazarides 3111, 18 June 1952 (K, MEL, NSW, NT, PERTH). NorTHERN Territory: Burt Plain, 36 miles [58 km] N of Alice Springs, Nelson 199, 30 Mar 1962 (CANB, K, NT). South Australia: Mt Chapple Bore, Cleland, 31 Aug 1951 (AD). QuEENSLAND: 5 miles [8 km] E of Surat, Pedley 1201, 31 Jan 1963 (BRI, CANB, K). NEW South WALES: 56 miles [ $90 \mathrm{~km}$ ] NNW of Wilcannia, on road to White Cliffs, De Nardi 264, 20 May 1969 (NSW).

36. S. kingii F. Muell.

(F. Mueller 1887b: 53)

TYPE: WESTERN AUSTRALIA: between the Gascoyne and Fortescue Rivers, King; holo MEL. 
S. kingii subsp. ornata A. Lee (A.T. Lee 1948: 181). Type: Western Australia: between Kunnunoppin and Mt Marshall, and Lake Barlee, Fitzgerald 449 \& Fraser, WinterSpring 1919; holo NSW.

A prostrate or ascending annual or perennial, perhaps reaching $c .15 \mathrm{~cm}$ high, with numerous stems, sometimes with bases below ground, and a taproot. Stems 1-2 mm wide, occasionally wider at the base, often conspicuously flexuose, usually ribbed from the nodes, glabrous or with sparse, usually appressed, flat or turgid, basifixed hairs $0.5 \mathrm{~mm}$ or less long and mostly tapering to a narrow tip. Leaves mostly $1.5-5 \mathrm{~cm}$ long, with (3-)5(-7) leaflets above a usually, but not always, extended petiole, the leaflets broadly to narrowly obovate, with scattered flat hairs probably limited to the lower surface, the lateral leaflets mostly 5-12 $\mathrm{mm}$ long and 2-9 mm wide, very variable on the plant and often with those lower on the leaf smaller, the terminal often much larger, the leaflet-apex usually obtusely to acutely rounded with a small point. Stipules often 5-20 mm long and longer than the leaflets, very oblique, the upper part narrowly ovate and virtually entire with the apex acute, at the base broadly rounded and auricle-like, green, usually not forming an abaxial ridge and glabrous or with a few marginal hairs, or with hairs on the inner surface. Racemes $1-5 \mathrm{~cm}$ long, with 1-3(-9) flowers of somewhat dissimilar age. Peduncle $0.5 \mathrm{~mm}$ or less wide, without a pulvinus, with flowers usually in the upper $1 \mathrm{~cm}$ or so but occasionally covering $1 / 2$, ribbed in the upper part, with sparse loosely appressed hairs. Bracts ovate- to linear-lanceolate, c. $1 \mathrm{~mm}$ long. Flowers pink to purple, 5-10 mm long, on glabrous or sparsely pubescent pedicels 1-2 mm long. Hypanthium broad-topped and often slender below, tending to contract at the top under the fruiting calyx, the bracteoles narrow and small. Calyx with the tube c. $1.5 \mathrm{~mm}$ long, gradually expanding from the hypanthium-top but remaining narrow, sometimes contracting below the lobes, glabrous or almost so, the lobes deltoid to long-acuminate-deltoid, shorter or longer than the tube, with the upper equal to or broader and shorter than the lower, the sinuses rather narrowly rounded to acute. Standard $5-10 \mathrm{~mm}$ long and almost as wide or somewhat narrower, tapering to a long broad tapered claw, with two very long vertical thickenings. Wings 5-c. $9 \mathrm{~mm}$ long, curved-oblong, the apex somewhat expanded and shortly obtuse, the claw long, very slender, tapered obliquely from a broad base, and turned upward (though straight), the auricle large, rounded, raised and recurved, with a fold along its base. Keel c. 5-8 mm long and usually c. $2 \mathrm{~mm}$ deep, the apex acute with the tip tapering to a fine beak-like point, somewhat expanded below, with a slight twist, with the upper margin with a strong downward curve between the tip and the rather large rounded raised or backwardly directed auricles, and with large long pockets, the claw long, slender, tapered and straight. Ovary 3-4 mm long, narrowly ovoid to narrowly oblong, glabrous or occasionally with an appressed pubescence, tapering suddenly, sometimes obliquely, at the base and more gradually at the apex to a long broad, even slightly expanded, tip. Ovules numerous. Stipe c. $0.5 \mathrm{~mm}$ long, and broad, or tapering to more slender and c. $1 \mathrm{~mm}$, glabrous. Style rather slender, with the extreme base a little broader and terete but otherwise untapered, laterally flattened and unstiffened with a slightly oblique truncate tip, usually with, but sometimes without, a few hairs behind it, not twisted, curved in the lower part and slightly so above, the beard variable, mostly short and only in the upper part. Fruit mostly $20-30 \mathrm{~mm}$ long and 2-6 mm wide, sometimes curved, narrowly subelliptic to narrowly obovate, inflated, with the suture often narrowly intruded, occasionally broadly, with the fruit dorsiventrally compressed, at the base very shortly tapered to a c. $1 \mathrm{~mm}$ stipe, and tapered at the apex often with the straight or upturned beak, behind the $2-3 \mathrm{~mm}$ recurved style, stiff and/or swollen, glabrous or occasionally with a minute appressed pubescence, becoming erect at maturity, the texture leathery, often stiffly but sometimes thin, the surface smooth or ridged, often strongly from the variably raised veins at $30^{\circ}$, dehiscent along both the 
suture and the lower surface, the tissue deep and sealing the loculus.

Widespread in Western Australia and just reaching western South Australia. Often in clay depressions, also in sand or loam, frequently associated with creek-beds or lakebeds or their margins. Fig. 16.

Lee separated the populations in the south-eastern half of the species' range as subsp. ornata. The form found in this area has stronger fruit-markings, broad-based fruit and, often, appressed hairs on the upper surface of the stipules, but some specimens from other areas show some of these features.

Selected specimens (from c. 65 examined): Western Australia: Pulhana Soak, Woodstock S, Burbidge 5967, 1 Feb 1958 (AD, CANB, NSW); Wandagee, Minilya River, Gardner 3211, 29 Aug 1932 (K, NSW, PERTH); Cape Inscription, Dirk Hartog Island, George 11569, 5 Sep 1972 (CANB, MEL, PERTH); Coolgardie, Helms, July 1899 (K, PERTH). South Australia: Connie Sue Highway, $28^{\circ} 30^{\prime}, 129^{\circ} 04^{\prime}$, Symon 24 Aug 1980 (AD, CANB, NSW).

\section{S. viridis J. Black}

\section{J.M. Black (1924: 225)}

TYPe: SOUTH Australia: Curnamona Station, north of Yunta, T.G.B. Osborn, 22 Aug 1923; holo $\mathrm{AD}$; iso $\mathrm{K}$.

A prostrate perennial to $\mathrm{c} .10 \mathrm{~cm}$ high, with numerous stems from a taproot or deep underground rooting system. Stems (1-)2-3(-4) $\mathrm{mm}$ wide with ridges from below the nodes, glabrous or with sparse, mostly minute, basifixed, rather turgid, blunt or tapered, mostly appressed hairs on young growth. Leaves 1-6 cm long, with (5-)7-9(13) leaflets above a rather short petiole, the leaflets obovate to narrowly obovate, with sparse hairs mostly on the midrib and margins and few on the upper surface, the lateral leaflets 5-15 $\mathrm{mm}$ long and (2-)4-8 $\mathrm{mm}$ wide, the terminal and all laterals not very dissimilar in size, the leaflet-apex broad and usually retuse or emarginate with a small point. Stipules (2-)5 to more than $10 \mathrm{~mm}$ long, obliquely ovate-deltoid, not or scarcely toothed, with very broad auricle-like bases, green and leaf-like, sometimes tending to extend down the stem, usually forming a well-developed abaxial ridge and with hairs mostly restricted to the margins. Racemes 4-20 cm long, with 5-10 flowers of even age. Peduncle (0.5-)1-2(-2.5) mm wide, with the pulvinus not developed, with flowers in the upper $1 / 4$ to $1 / 2$, ribbed, the pubescence sparse, of minute slender appressed hairs. Bracts ovate, 1-2 mm long. Flowers purple, 7-12 mm long, on sparsely pubescent pedicels c. $2 \mathrm{~mm}$ long. Hypanthium short and often broad, contracting at the apex under the fruiting calyx, the bracteoles conspicuous, broad and green. Calyx with the tube c. $2 \mathrm{~mm}$ long, obliquely expanded above the hypanthiumtop, and somewhat contracting below the lobes, virtually glabrous, the lobes almost broad-lanceolate with narrow acuminate tips, somewhat longer or shorter than the tube, the sinuses narrowly rounded, the upper deeper. Standard 7-12 $\mathrm{mm}$ long and approximately as wide, tapering to, or rounded above, a very short scarcely tapered slender claw, somewhat drawn in at the top of the claw but without thickenings. Wings 5-8 $\mathrm{mm}$ long, curved, deltoid, the apex narrowly rounded, the claw, long, slender, tapering and slightly curved, the auricle deep and rounded-deltoid, slightly folded, and not raised. Keel (Fig. 5) 7-10 mm long and 5-6 mm deep, with the apex shortly obtuse, the tip below the upcurved upper margin that curves evenly up from the tip and down to the short or negligible auricles, and with pockets below vertical folds in the auricles, the claw short, narrow, a little tapered and recurved. Ovary c. 3$3.5 \mathrm{~mm}$ long, obliquely elliptic-oblong, curved, glabrous or with dense short hairs, appressed or with a few raised near the base of the suture, the apex obliquely and 
shortly tapering, the base contracting from the top and downcurved. Ovules numerous. Stipe $0.75 \mathrm{~mm}$ long, slender, curved, glabrous. Style scarcely tapering from the narrow base to the narrowly rounded tip that often has the stigmatic section angled inward, not strongly flattened and in the upper c. $2 / 3$ becoming somewhat stiffened and extended laterally so that almost hemispherical in cross-section, not twisted, strongly curved c. $1 / 3$ from the base and above this with a slight backward curve, the beard mostly in the upper $2 / 3$, longer and denser in the upper $1 / 3$ and reaching the tip. Fruit 25-35 mm long and c. $3 \mathrm{~mm}$ wide, narrowly elliptic-cylindrical or a little broader above the middle, slightly curved, the suture deeply and narrowly intruded with the lateral parts much inflated, very shortly tapered at the base with a very slender stipe c. $1 \mathrm{~mm}$ long, and more gradually, occasionally narrowly obtuse, behind a short beak or the narrow base of a twisted c. $5 \mathrm{~mm}$ style; erect at maturity, dehiscence not seen, perhaps along the suture, pubescent with sparse short appressed hairs or glabrous, the surface smooth, the veins delicate at c. $30^{\circ}$, the texture softly leathery, the tissue well developed, perhaps closing the loculus.

In the Flinders Ranges and Broken Hill area of South Australia and New South Wales. In dry sandy or stony areas, on the banks, or in the beds, of creeks. Fig. 16.

Selected SPECIMENS (from c. 50 examined): SOUTH Australia: $9 \mathrm{~km}$ SW of Wearing, E of Lake Frome, Sikkes 940 \& Ollerenshaw, 29 Sep 1973 (AD, NSW, PERTH); Martins Well Homestead, 80 km NE of Hawker, Sikkes 1238 \& Ollerenshaw, 29 Sep 1973 (AD, CBG, NSW); $10 \mathrm{~km} \mathrm{SE} \mathrm{of}$ Erudina Homestead towards Yunta, Sikkes 1246 \& Ollerenshaw, 29 Sep 1973 (AD, NSW, PERTH). NeW SoutH WaLES: near Silverton, Irvine, Aug 1889 (MEL); Stephens Creek, Broken Hill, Morris 1348, Sep 1925 (AD, NSW).

\section{S. perlonga J. Thompson, sp. nov.}

Herba procumbens perennis usque ad $1 \mathrm{~m}$ sed plerumque minor. Foliola 7-13 ovata vel obovata. Racemi 8-25 mm longi floribus c. $10 \mathrm{~mm}$ longis. Calyx lobis acuminatis tubo subaequantibus. Vexillum versus basim lineis crassis. Carina obtusa vel acuta. Stylus angustus plus minusve retrocurvus apice oblique truncato. Fructus $15-20 \mathrm{~mm}$ longus 3-6 mm latus ellipticus curvatus.

TYPE: WeStern Australia: prope collis Singleton, C.A. Gardner 12028, 17 Aug 1953; holo PERTH.

A scrambling perennial said to reach c. $1 \mathrm{~m}$ high but probably usually much shorter, with a short woody branched base, perhaps above a stout taproot, the stem-bases often below the soil-surface. Stems usually 1-1.5 mm wide, shallowly to strongly ribbed with sparse, minute, slender, flat or rather turgid, basifixed hairs at least on young growth. Leaves $3-6 \mathrm{~cm}$ long, with 7-13 leaflets above a petiole that is usually extended but occasionally short, the leaflets variable in shape from obovate to ovate or even orbicular, also variable in texture which is occasionally thick, with sparse appressed hairs absent from the upper surface, the lateral leaflets $3-c$. $12 \mathrm{~mm}$ long and mostly 4-6 mm wide, the terminal mostly a little longer than the upper laterals, the leaflet-apex mostly rounded with a short stiff point. Stipules $1-c .7 \mathrm{~mm}$ long, obliquely ovate with the apex obtuse to shortly acute or acuminate, not toothed but the margin sometimes irregular, with auricle-like expansion at the base, green and leaf-like, with the abaxial ridge usually well developed but occasionally obscure on older stems, and pubescent on both sides or the inner or both glabrous and the hairs marginal. Racemes 8-25 cm long, usually with 7-10 flowers of slightly dissimilar age. Peduncle c. $1 \mathrm{~mm}$ wide, with the pulvinus absent, the flowers in the upper $1 / 3$ or less, strongly ribbed, the pubescence sparse but more dense in the upper part and of minute appressed hairs. Bracts ovate-lanceolate, c. $2 \mathrm{~mm}$ long. Flowers purple to lilac- 
pink, c. $10 \mathrm{~mm}$ long, on pubescent pedicels c. $2 \mathrm{~mm}$ long. Hypanthium short and broad, or attenuate, tending to contract under the fruiting calyx, the bracteoles minute. Calyx with the tube 2-2.5 mm long, somewhat obliquely inflated above the hypanthium-top and a little contracted below the lobes, with a sparse appressed pubescence, the lobes deltoid to narrowly deltoid and variably acuminate to long-acuminate at their apices, mostly about as long as the tube, the upper shorter and often broader, and often shorter than the tube, the sinuses broadly rounded to somewhat acute, the uppermost larger. Standard c. $10 \mathrm{~mm}$ long and as broad, tapering to a short slender tapered claw, with two spaced angled long and shallow thickenings at the base. Wings c. $9 \mathrm{~mm}$ long, almost long-deltoid, the apex narrowly rounded, the claw long and tapering from a broad base to a slender tip, somewhat curved, the auricle deep, and rounded-deltoid, with a fold across below the auricle. Keel c. $10 \mathrm{~mm}$ long and 4-5 $\mathrm{mm}$ deep, with the apex shortly obtuse and sometimes a little retracted below a deep, forwardly extended, obtuse or rather acute tip, with the upper margin raised at the broad tip and almost straight, behind this with a short upcurved arc or remaining raised and descending closer to the deep and rounded, somewhat raised auricles, and with deep pockets, the claw long, slender, little tapered and somewhat recurved. Ovary c. $5 \mathrm{~mm}$ long, elliptic or broader above the middle, curved, with a close pubescence raised somewhat on the lower sutural side, the apex and base obliquely tapered from the top. Ovules numerous. Stipe c. $1 \mathrm{~mm}$ long, slender, glabrous. Style narrow-based, not tapering, very slightly expanding at c. 1/3 its length and then untapered to the obliquely truncate tip, not flattened except on the base of the upper c. 1/3 where almost hemispherical, somewhat variably stiffened in the upper $2 / 3$, not twisted, with a strong curve below and a straight or slightly outbowed stiffened $2 / 3$, the tip inflexed towards the beard on the short side of the truncate tip, the beard dense and long but restricted to the upper c. $1 / 3$ of the style. Fruit 15-20 mm long and 3-6 mm wide elliptic, curved, strongly dorsally compressed, with the suture scarcely intruded, to almost cylindrical with the suture deeply intruded, somewhat inflated, shortly tapered at the base, above a very slender c. $1 \mathrm{~mm}$ stipe and at the apex, shortly tapered to, or rounded behind or below, a minute beak often bearing the reflexed c. $6 \mathrm{~mm}$ style, somewhat raised but not seen above the horizontal at maturity, the dehiscence seen only near the tip on the opposite side but perhaps also near the suture, with short spreading hairs, the texture thin, rather soft to stiff, the surface somewhat reticulate, tissue absent, the veins somewhat raised at $60^{\circ}-90^{\circ}$.

In western Western Australia. On rather saline flats. Fig. 16.

This species is named for its location, so far from the very similar S. viridis. From the Latin perlongus, very long.

SPECIMENS EXAMINED: WeSteRn Australia: Wagga Station, Humphries, 27 Sep 1950 (PERTH); Yuna, Ashby 956, 15 Aug 1964 (AD); Rockwell, 7 miles [11 km] W of Yuna, NE of Geraldton, Burns 18, 13 July 1967 (PERTH).

\section{S. longicarinata J. Thompson, sp. nov.}

Herba plerumque prostrata perennis vel interdum annua usque ad c. $20 \mathrm{~cm}$ alta. Foliola 5-11 anguste lanceolato-elliptica vel obovata. Racemi plerumque ad $20 \mathrm{~cm}$ longi interdum longiores floribus plerumque 12-14 mm longis. Calyx lobis tubo subaequantibus. Vexillum versus basim incrassatum et callis duobus. Carina longa acuta. Stylus complanatus apice angusto cursu vario. Fructus $30-45 \mathrm{~mm}$ longus c. $2.5-4 \mathrm{~mm}$ latus ellipticus vel cylindricus.

TYPE: WeStern Australia: $2.4 \mathrm{~km}$ SW of Cape Inscription, Dirk Hartog Island, A.S. George 11572, 5 Sep 1972; holo PERTH. 
S. phacoides var. grandiflora Benth. (G. Bentham 1864: 218); S. phacoides subsp. grandiflora (Benth.) A. Lee (A.T. Lee 1948: 174). TYPE: WESTERN Australia: Nichol Bay and De Grey River, Ridleys Exped., Dec 1863; lecto (fide Lee 1948: 174) MEL; iso K.

A prostrate, perhaps sometimes ascending, perennial or sometimes annual, plant to c. $20 \mathrm{~cm}$ high, with a number of stems, often with their bases below ground, from a taproot. Stems often c. $2 \mathrm{~mm}$ wide, ridged, often obscurely, pubescent, with hairs rather broad, of variable length but most c. $0.5 \mathrm{~mm}$ long, basifixed or laterally attached near the base, flat or turgid, elliptic or tapering towards the apex, and usually appressed but sometimes antrorsely divergent. Leaves $2-7 \mathrm{~cm}$ long, with 5-11 leaflets above a short petiole, the leaflets very variable, from narrowly lanceolate-elliptic to obovate, sometimes thick in texture, pubescent with spreading to appressed hairs variable in length and density on both surfaces but often sparse on the upper, the lateral leaflets from less than 5 to a little more than $10 \mathrm{~mm}$ long, and 1-6 $\mathrm{mm}$ wide, the terminal variable in proportion to the laterals, the leaflet-apex obtuse, rarely acute, and often emarginate, usually with a short acuminate point. Stipules $2-$ c. 10 $\mathrm{mm}$ long, obliquely linear-lanceolate to somewhat ovate with a long-extended tip, and sometimes with the base extended, green, usually forming a rather variably developed abaxial ridge and pubescent on the outer surface and margins with few or no hairs on the inner surface. Racemes from less than 5 to more than $20 \mathrm{~cm}$ long, with c. 7 flowers of similar age. Peduncle $0.5-1.5 \mathrm{~mm}$ wide, with the pulvinus not developed, with flowers in the upper $1 / 4$ or less, ribbed, the pubescence rather sparse, of basifixed, appressed, turgid, flat hairs. Bracts ovate, 1-1.5 mm long. Flowers purple, mostly 12-14 mm long, on densely pubescent pedicels $2-3 \mathrm{~mm}$ long. Hypanthium short, contracting at the apex under the fruiting calyx, the bracteoles minute. Calyx with the tube c. $2 \mathrm{~mm}$ long, rather obliquely broad-based and further expanding above, sometimes a little contracted below the lobes, sparsely or densely pubescent with short appressed hairs, the lobes deltoid or somewhat ovate to broad-lanceolate, almost equal to or slightly shorter than the tube, the sinuses variable, often narrowly rounded. Standard c. 11-12 $\mathrm{mm}$ long and 12-15 $\mathrm{mm}$ wide, contracted or rounded at the base above a short slender tapered claw, with two vertical thickenings, and, at their base, two conspicuous horizontal flaps, often folded back. Wings c. $10 \mathrm{~mm}$ long, curved-obovate-oblong with the apex variably and shortly, sometimes obliquely (with the upper edge longer) obtuse, the claw very short, tapered from a broad base, and strongly curved, the auricle small, deltoid or rounded, raised or recurved, and often folded. Keel 12-14 mm long and 4-5 mm deep, with the apex acute with the tip narrow, with the upper margin usually straight, sometimes rather sharply upcurved to the tip, the auricles small rounded and directed backwards, with conspicuous pockets at the base, the claw rather short, slender, a little tapered and slightly recurved. Ovary c. $6 \mathrm{~mm}$ long, curved and very narrowly ovate-elliptic, densely pubescent with short hairs, the apex long-, but slightly, tapered, the base shortly tapered. Ovules numerous. Stipe c. $0.5 \mathrm{~mm}$ long, slender and glabrous. Style flattened from the rather broad base to near the tip, curving downward from the ovary then strongly upward, less curved in the upper half where sometimes a little recurved, not twisted, the long slender less flattened tip variously disposed and with a rounded apex, all of very thin texture, bearded along the whole length. Fruit $30-35 \mathrm{~mm}$ long and c. $2.5-4$ mm wide, elliptic to narrowly cylindrical, slightly curved, dorsiventrally compressed with the suture somewhat indented but sometimes with the sides raised and the suture deeply intruded, at the base tapering to a narrow stipe-like section above a minute stipe, at the apex tapering shortly to a tapering narrow straight beak behind the c. $6 \mathrm{~mm}$ curved or twisted style, raised or sometimes erect at maturity, the dehiscence not seen but probably along the suture, with basifixed divergent to closely appressed hairs, the texture softly leathery, the surface smooth, the delicate veins at c. $60^{\circ}$, the tissue not deep but probably closing the loculus. 
On the western coast of Western Australia. In a variety of habitats, especially on coastal calcareous dunes and heath over limestone, but also in clay. Fig. 16.

This species is named for its long keel in which feature it resembles $S$. phacoides. From the Latin longus, long; carinatus, keel.

SeLECTED SPECIMENS (from 10 examined): Western Australia: coast near West Coast Mill, Dirk Hartog Island, George 11589, 6 Sep 1972 (CANB, PERTH); Dirk Hartog Island, Bates, 1892 (MEL); False Entrance Bay, Beard 6811, 11 Oct 1973 (NSW, PERTH); Shark Bay, Galbraith WA274, 8 Aug 1964 (AD); near Johnson Bore, Tamala Station, George 9576, 27 Aug 1969 (PERTH).

\section{S. unifoliolata F. Muell.}

\section{(F. Mueller 1874: 226)}

TyPe: Western AustRalia: between Barrow and Rawlinson's Ranges, E. Giles, 1874; holo MEL; iso NSW, PERTH.

An erect or ascending perennial often c. $30 \mathrm{~cm}$ high, with several branched stems from a taproot. Stems (1.5-)2-3(-5) $\mathrm{mm}$ wide, terete or, on young growth, rather ribbed, and angled below nodes, often densely pubescent with the pubescence varying from flat or turgid, elliptic, minute, appressed hairs c. $0.5 \mathrm{~mm}$ long to terete, crisped, fine pointed hairs of c. $1 \mathrm{~mm}$, the hairs basifixed. Leaves $1-\mathrm{c} .7 \mathrm{~cm}$ long, with one leaflet, or occasionally 3 (or 5 ) leaflets above a variously extended, often short, petiole, the unifoliolate leaves on the lower part of the branches, the leaflets mostly broadly to narrowly obovate, with a close pubescence often sparse on the upper surface, mostly 10-26 mm long and 5-15 $\mathrm{mm}$ wide, and when more than one, the terminal much larger than the laterals, the leaflet-apex broadly obtuse or retuse, sometimes with a minute stout point. Stipules 3-5 $\mathrm{mm}$ long, broadly and obliquely to narrowly deltoid, acute to acuminate, mostly green, forming a distinct abaxial ridge or collar and pubescent on both surfaces. Racemes $1-8(-12) \mathrm{cm}$ long, with 4-c. 15 flowers of somewhat dissimilar age. Peduncle $0.5-1.5 \mathrm{~mm}$ wide, without a pulvinus, with the flowers occasionally over $1 / 2$, usually over all its length, ribbed, pubescent with dense, crisped to straight and appressed hairs. Bracts ovate-acuminate, 1-4 mm long. Flowers purple, 6-8(-10) $\mathrm{mm}$ long, on pubescent pedicels usually $2 \mathrm{~mm}$ long, occasionally to $4 \mathrm{~mm}$ or more. Hypanthium short, tending to contract at the apex and occasionally extend at the base under the fruiting calyx, the bracteoles minute. Calyx with the tube 1.5-2(-3) $\mathrm{mm}$ long, obliquely expanding above the hypanthium-top, rather narrow, and a little contracted below the lobes, with a short spreading or appressed pubescence, the lobes long-deltoid-acuminate, slightly longer or shorter than the tube, the sinuses narrow. Standard 7-13 $\mathrm{mm}$ long and 6-11 mm wide, rather abruptly tapering to a long claw tapered above and slender below, with two thickenings (occasionally without) close and almost vertical at the base and a somewhat concave above this. Wings 7-10 mm long, narrowly oblong, the apex, narrowly to rather broadly, shortly obtuse, the claw long, slender, somewhat tapered and curved, the auricle deep, truncate to ovate-deltoid and raised, and twisted. Keel c. 7-10 mm long and 2-3 mm deep, with the apex acutely and often narrowly rounded, with the upper margin rising for some distance behind the tip before curving downward slightly and rising to the rather short rounded and backwardly directed auricles, pockets absent, the claw long, slender, little tapered and recurved a little or straight. Ovary 3-5 mm long, very narrowly ovate, curved, often strongly in the lower part, with a dense, minute, appressed pubescence, or with a longer pubescence raised along the suture and reversed at its base, the apex long and rather obliquely tapering, the base shortly and very obliquely tapered. Ovules numerous. Stipe almost $1 \mathrm{~mm}$ long, curved, pubescent. Style laterally flattened but not or scarcely stiffened, not 
twisted, evenly curved, tapering from the narrow base only near the apex where gradually and slightly tapered to a truncate tip with a few short antrorse hairs or a strong arc of hairs behind it, the beard sparse but often more dense towards the tip. Fruit mostly $20-25 \mathrm{~mm}$ long and $2-4 \mathrm{~mm}$ wide, narrowly elliptic, inflated, often curved, sometimes dorsiventrally compressed with a wide suture but often almost cylindrical when the sides fold up to enclose the suture, at the base contracting to a minute stipe-like section above the c. $1 \mathrm{~mm}$ stipe and at the apex shortly tapering or narrowly rounded below a laterally flattened upcurved beak with the recurved or coiled style c. 3-4 mm long usually shed, pendulous at maturity, dehiscent along the suture, with minute close or longer and tangled hairs, the texture soft and stiff and sometimes rather thin, the surface with the veins almost invisible or a little broadly raised, occasionally minutely tuberculate, the veins at c. $45^{\circ}$, the tissue short and even, not quite closing the locules at maturity.

In eremean parts of Western Australia, South Australia and the Northern Territory. Usually associated with the margins of salt lakes and also recorded as being on gypsum and limestone. Fig. 17.

Selected SPECimens (from c. 25 examined): Western Australia: Lake Austin, Ashby 3459, 7 Aug 1970 (AD, PERTH). NORTHERN TERRTTORY: 3 miles [5 km] SE of Sangsters Bore, Maconochie 1789, 22 July 1978 (AD, BRI, NSW, NT, PERTH); 13.5 miles [27.5 km] N of Angas Downs Station, Lazarides 6137, 5 Oct 1956 (AD, BRI, CANB, MEL, NSW, NT); Erldunda Station, Latz 4950, 25 Apr 1974 (AD, NT). South Australia: 20 miles [32 km] W of Emu, Forde 471, 3 Sep 1956 (AD, CANB).

\section{S. tanamiensis J. Thompson, sp. nov.}

Herba prostrata vel erecta perennis usque ad c. $25 \mathrm{~cm}$ alta. Foliola 5-13 lato-ovata vel elliptica vel subcircularia. Racemi $2-12 \mathrm{~cm}$ longi floribus $12-18 \mathrm{~mm}$ longis. Calyx lobis tubo subaequantibus. Vexillum versus basim concavum callis duobus et incrassatum interdum lineis crassis. Carina obtusa vel subacuta. Stylus angustatus apice subincurvo. Fructus plerumque $15-30 \mathrm{~mm}$ longus $3-4 \mathrm{~mm}$ latus angusto-ellipticus curvatus.

TYPE: NORTHERN TERRTORY: Tanami Desert, W margin of Lake Ruth, W.R. Barker 2818, 18 Aug 1975; holo NSW; iso AD, BRI, CANB, K, NT.

A prostrate or erect perennial to $\mathrm{c} .25 \mathrm{~cm}$ high, with numerous stems from the top of a taproot, their bases sometimes below ground. Stems mostly 1-2 mm wide, occasionally to $4 \mathrm{~mm}$ at the base, ridged, often conspicuously flexuose, with scattered, minute, turgid, blunt or occasionally tapered, elliptic or oblong, appressed and basifixed hairs. Leaves mostly 3-8 cm long, with 5-13, occasionally stipellate, leaflets above a variably extended petiole, the leaflets from broadly ovate or elliptic to almost orbicular, with scattered hairs on the lower surface, the lateral leaflets variable in size, 1-15 mm long and often 3-8 mm wide, the terminal somewhat longer than the smaller upper laterals, the leaflet-apex often retuse, occasionally broadly acute with a short point. Stipules from (3-)8(-15) $\mathrm{mm}$ long, obliquely deltoid to long-acuminate- deltoid, with the base usually auricled and descending down the stem, strongly but sometimes shallowly toothed, green, not forming an abaxial ridge and with appressed hairs on the inner surface. Racemes 2-12 cm long, with 1-8 flowers of rather uneven age. Peduncle from less than 0.5 to $c .1 \mathrm{~mm}$ wide, without a pulvinus, the flowers usually occupying the top centimetre or two but occasionally $1 / 2$ the peduncle-length, ribbed, with sparse minute hairs. Bracts ovate, c. $1 \mathrm{~mm}$ long. Flowers purple, (12-)15(-18) mm long, on sparsely pubescent pedicels 2-3 mm long. Hypanthium short and often rather broad, conspicuously contracted at the top under the fruiting calyx, the bracteoles 
minute. Calyx with the tube $2-2.5 \mathrm{~mm}$ long, obliquely expanding above the hypanthium-top, glabrous or with a few scattered hairs, the lobes deltoid, acute or acuminate, equal to or a little shorter than the tube, the sinuses varying from acute to broadly rounded. Standard 10-15 $\mathrm{mm}$ long and 8-10 $\mathrm{mm}$ wide, the base contracting to a rather long slender tapered claw, with two distinct calli and a central thickened, sometimes as two vertical thickenings, region below a concave area. Wings 8-14 mm long, slightly curved, narrowly oblong, the apex obtuse, the auricle long, recurved, rounded and folded, the claw short, slender, tapered and somewhat curved. Keel 10$15 \mathrm{~mm}$ long and 3-6 mm deep, with the apex obtuse or rather acute, slightly twisted, somewhat swollen below the narrow somewhat retracted or extended tip, with the upper margin almost straight but varying slightly in the position and extent of dip before the auricle, the auricles rather deep, long and recurved, with big pockets, the claw very short, straight, relatively broad and tapered only at the base. Ovary c. 6-8 $\mathrm{mm}$ long, very narrowly elliptic, curved, with a minute appressed pubescence variable in extent but especially on the sides, very long-tapering at the apex, where merging into the style-base, and at the base. Ovules numerous. Stipe c. $1 \mathrm{~mm}$ long, slender, glabrous. Style slender, the base merging into the ovary-apex, tapering gradually to a very slender, slightly incurved, tip, evenly curved, not twisted, scarcely laterally flattened or thickened, with the surface below the beard narrow but flat, the beard over much of the length, including the tip but longer and more dense in the upper 2/3. Fruit mostly $15-30 \mathrm{~mm}$ long and 3-4 $\mathrm{mm}$ wide, narrowly elliptic or broader towards the apex, strongly curved, a little dorsiventrally compressed, inflated, with the suture shallowly and narrowly intruded, at the base long-tapering to the slender c. $1.5 \mathrm{~mm}$ stipe, at the apex tapering to a tapered stiff beak bearing the recurved style c. $7 \mathrm{~mm}$ long, dehiscent at the suture, the hairs minute, few and scattered, the surface leathery, with a strong reticulation of raised veins at c. $60^{\circ}$, the tissue very deep and closing the loculus.

In eremean parts of northern Western Australia and western Northern Territory. On sandy flats, especially at the edges of saline depressions or lakes. Fig. 17.

This species is named for the Tanami Desert, the source of a number of specimens.

Selected specimens (from c. 20 examined): Western Australia: Pardoo Station, $\mathrm{N}$ of De Grey River, Burbidge 1523, 24 July 1941 (PERTH); $18 \mathrm{~km}$ NE of Mt Marsh, c. $95 \mathrm{~km}$ E of Wittenoom, Newbey 10238, 29 June 1984 (PERTH). NORTHERN TERRITORY: Lake Ruth, near Mongrel Downs Station, Crisp 600, 18 May 1983 (CBG, MEL); 3 miles [5 km] SE of Sangsters Bore, Tanami, Maconochie 1791, 22 July 1973 (CANB, K, NT); c. 1 mile [1.5 km] W of Central Mt Wedge Station, Nicholls, 8 June 1968 (BRI, K, NSW, NT).

\section{S. laciniata A. Lee}

(A.T. Lee 1948: 182)

TyPe: WeStern Australia: Dingo Creek, Malcolm, C.A. Gardner, 16 Sep 1927; holo PERTH.

A prostrate or erect slender, perhaps perennial, plant to $\mathrm{c.} 15 \mathrm{~cm}$ high, with numerous stems from the top of a taproot. Stems 1-2 mm wide, often ridged, often conspicuously flexuose, with scattered minute turgid, blunt or tapered narrowly elliptic to almost globose basifixed appressed hairs. Leaves 1-7 cm long, with 7-13, occasionally stipellate, leaflets above a variably extended petiole, the leaflets broadly elliptic to broadly ovate, with scattered hairs on the lower surface, the lateral leaflets variable in size on the plant, from $2-9 \mathrm{~mm}$ long and usually $2-4 \mathrm{~mm}$ wide, the terminal usually somewhat larger, but sometimes shorter, than the slightly smaller upper laterals, the leaflet-apex often so retuse as to appear cordate but sometimes acute, usually with a 
small point. Stipules $1-\mathrm{c} .10 \mathrm{~mm}$ long, very obliquely broad-deltoid and broader than long, with the base broad and sometimes extending down the stem, mostly strongly toothed, green or scarious, not forming an abaxial ridge and with appressed hairs on the inner surface. Racemes $2-8 \mathrm{~cm}$ long, with 3-8 flowers of rather uneven age. Peduncle from less than 0.5 to $0.5(-1) \mathrm{mm}$ wide, without a pulvinus, with flowers occupying from less than $1 / 4$ to more than $1 / 2$ the length, ribbed, especially in the upper part, with scattered hairs, sometimes longer and dark in the upper part. Bracts ovate to lanceolate, c. $1 \mathrm{~mm}$ long. Flowers purple, 5-8 mm long, on dark- or light-pubescent pedicels 1-2 mm long. Hypanthium very short, tending to contract at the apex under the fruiting calyx, the bracteoles minute. Calyx with the tube $1.5-2 \mathrm{~mm}$ long, gradually or suddenly widening above the hypanthium-top, glabrous or with marginal hairs, the lobes deltoid, somewhat longer than wide, approximately as long as the tube, the sinuses broadly rounded. Standard 6-8 $\mathrm{mm}$ long and as wide or a little narrower, tapering to a short broad claw, without thickening at the base. Wings 4-6 $\mathrm{mm}$ long, slightly curved, oblong-deltoid, with the apex shortly obtuse, the auricle large and rounded, and backwardly directed, the claw short with an oblique broad base, and much tapered and curved. Keel 3-7 $\mathrm{mm}$ long and 3-4 $\mathrm{mm}$ deep, with the apex slightly twisted, obtuse or acute, somewhat swollen below a blunt or minute and acute beak, with the upper margin very slightly downcurved between the tip and the rather deep and sometimes long, backwardly directed auricles, and with small pockets, the claw very short, tapered and slightly recurved. Ovary c. $3 \mathrm{~mm}$ long, narrow-elliptic, curved, glabrous or with a minute scattered pubescence or with longer hairs along the suture, tapering at the apex to a narrow tip extending into the style-base and more abruptly and obliquely to a very slender base. Ovules numerous. Stipe c. $0.5 \mathrm{~mm}$ long, slender, glabrous. Style slender, the base scarcely distinguishable from the narrow ovary-apex, above scarcely tapered and not stiffened in the lower part, the upper c. $2 / 3$ pale and stiffened and very slightly laterally compressed, tapering to a narrow apex with a narrow and tapered flexible tip, curved strongly in the lower part but only slightly in the upper, somewhat twisted with a rather dense beard in the upper $1 / 2$ to $3 / 4$ and on the tip, sometimes with beard-like hairs behind the tip. Fruit mostly $10-17 \mathrm{~mm}$ long and $2.5-4 \mathrm{~mm}$ wide, subelliptic or wider towards the apex, somewhat curved, gradually tapered to the c. $0.5 \mathrm{~mm}$ stipe, inflated, with the suture mostly narrowly and always deeply intruded, not or scarcely dorsiventrally compressed, at the apex shortly tapered or rounded behind a stiff upwardly inclined beak bearing the c. $3 \mathrm{~mm}$ recurved style or its base, raised at maturity, the dehiscence not seen, the surface usually with an inconspicuous pubescence of minute hairs and a strong pattern of raised veins, at $60^{\circ}$, the texture leathery, the tissue very deep and closing the loculus.

In central Western Australia and the southern part of the Northern Territory. On saline flats. Fig. 17.

Selected specimens (from 7 examined): Western Australia: 101 miles [160 km] NE of Wiluna, on Carnegie road, George 5599, 28 July 1963 (PERTH); 14 miles [22 km] E of Carnegie Station Homestead, George 5528, 27 July 1963 (NSW, PERTH). NORTHERN TERRITORY: 15.5 miles [25 km] E of Mt Wedge Station, Lazarides 6053, 19 Sep 1956 (AD, BRI, CANB, MEL, NSW, NT); Napperby Station, Latz 609320 Jan $1972(\mathrm{~K}, \mathrm{NT})$.

\section{Group 7}

1 Stems usually $1.5-4 \mathrm{~mm}$ wide; flowers $6-8 \mathrm{~mm}$ long

43. S. luteola

$1^{*}$ Stems usually c. $1 \mathrm{~mm}$ or less in width; flowers $3-5 \mathrm{~mm}$ long

2 Stems with sparse minute hairs; leaflets 9-13

44. S. oliveri

$2^{*}$ Stems with rather dense hairs often $0.75 \mathrm{~mm}$ long; leaflets 5-7

45. S. leeana 
43. S. luteola F. Muell.

(F. Mueller 1859a: 75)

TYPE: QueEnSLAND: Peak Downs, F. Mueller; holo MEL; iso K, (fragment NSW).

S. luteola var. dietrichiae Domin (K. Domin 1926: 2071). TYPE: QUEENSLAND: Rockhampton, A. Dietrich 599 (n.N. 213), 1863-5; holo PR, n.v., photo NSW; iso MEL, NSW.

A low-growing prostrate or procumbent to semi-erect perennial to c. $50 \mathrm{~cm}$ high, with numerous branched stems, often with their bases below the soil-surface, from a taproot. Stems $1.5-4 \mathrm{~mm}$ wide, ridged, especially when young, with very sparse to dense hairs, the hairs basifixed, c. $0.5 \mathrm{~mm}$ long, tapering to a narrow apex, often somewhat flattened, usually straight, though sometimes irregular, and loosely appressed. Leaves 3-c. $10 \mathrm{~cm}$ long, with 3-17 leaflets above a usually short petiole, the leaflets narrowly elliptic to obovate, with a rather loosely appressed pubescence usually restricted to the lower surface, the lateral leaflets mostly 5-20 mm long and 3-10 $\mathrm{mm}$ wide, the terminal sometimes a little longer than the upper laterals that are slightly smaller than the lower, the leaflet-apex obtuse and with or without a short rounded point, or retuse or, occasionally, acute and pointed. Stipules $2-5 \mathrm{~mm}$ long, broadly to narrowly obliquely deltoid, and variably acuminate, the margins sometimes erose, green, forming a distinct and usually deep abaxial ridge, and pubescent on the outer surface and margins, with few, if any, hairs inside. Racemes $1-8 \mathrm{~cm}$ long, with 5-c. 15 flowers of rather dissimilar age. Peduncle $0.5-1.5 \mathrm{~mm}$ wide, without a pulvinus, with flowers occupying more than $1 / 2$ the length, ridged or angled, pubescent especially near the flowers. Bracts ovate-lanceolate, c. $1.5 \mathrm{~mm}$ long. Flowers $6-8$ $\mathrm{mm}$ long, purple or occasionally yellow, on pubescent pedicels usually less than 1 $\mathrm{mm}$ long. Hypanthium short and broad, the apex tending to contract and differentiate from the fruiting calyx, the bracteoles minute. Calyx with the tube $1.5-2 \mathrm{~mm}$ long, scarcely expanding above the hypanthium-top and gradually and only a little beyond, pubescent, the lobes deltoid and acute to long-aristate, from about equal to much longer than the tube, the sinuses rather broad. Standard (Fig. 3) 6-9 mm long and 5-8 $\mathrm{mm}$ wide, tapering to the base, or contracting to a tapered claw, without calli or thickening, not fully, or scarcely lifted. Wings 3-5 mm long, in general almost deltoid, the apex narrow and rounded, the claw long, deep at the base and somewhat downcurved, much-tapered and somewhat curved, the auricle very large, rounded and recurved, with a fold below it. Keel 5-8.5 mm long and c. $2 \mathrm{~mm}$ deep, with the apex somewhat twisted, obtuse and rather expanded below a tip that is often minutely lipped, without pockets, the upper margin very slightly downcurving from behind the slightly raised and rounded tip to the scarcely raised and very deeply truncate auricles, the claw long, slender, tapering and almost straight. Ovary 3-5 mm long, narrowly subelliptic, curved, downcurved and obliquely, rather shortly, tapered at the apex, and obliquely, rather shortly, tapered at the base, glabrous and pubescent. Ovules numerous. Stipe c. $0.25 \mathrm{~mm}$ long, relatively stout, glabrous. Style slender, unthickened, untapered, strongly curved especially near the base, laterally somewhat flattened in the central area, expanding dorsally at the strongly incurled tip with the variably developed antrorse arc of hairs that is often behind the obtuse tip within the curve and the short broad stigmatic area at an angle to it, the beard minute or absent. Fruit mostly 20-35 mm long and 3-8 $\mathrm{mm}$ wide, subelliptic to narrow-oblong, inflated, dorsiventrally compressed, the suture variously intruded, tapering shortly at the base to a minute stipe and more gradually at the apex to a short to long, often slightly raised, laterally flattened, acute beak bearing the 1-1.25 mm recurved style, conspicuously erect at maturity, dehiscent at the suture, glabrous or with sparse appressed fine hairs, the texture thin and soft or brittle, the surface smooth to closely 
and finely reticulate, the venation at c. $45^{\circ}$, the tissue short and even, often not closing the loculus.

Widespread in south-eastern Queensland, especially west of the dividing range, and in central New South Wales, and in north-western Victoria. Usually in rich heavy soil in open grassland, occasionally found after fire.

Fig. 18.

Selected SPECIMENS (from c. 120 examined): QueEnSLAND: 3 miles [5 km] E of Peak Downs Station, Adams 1297, 17 Sep 1964 (BRI, CANB); 'Plevna Downs', 25 miles [40 km] ENE of Augathella, Everist, 31 Oct 1939 (BRI, NSW). NEW SOUTH WALES: 17 km NW of Brewarrina, Paijmans 3197, 21 Aug 1979 (CANB); 'Rainbow Ridge', Nymagee, Cunningham \& Milthorpe 4370, 7 Apr 1976 (NSW). VictoRIA: 22 miles [35 km] W of Mildura on the Sturt Highway, then 6 miles [10 km] N, Henshall (MEL).

\section{S. oliveri F. Muell.}

(F. Mueller 1882: 152)

TYPE: WESTERn Australia: near Port Eucla, John Oliver, 2 June 1882; holo MEL; iso AD, NSW, PERTH.

A very slender prostrate to ascending plant up to c. $15 \mathrm{~cm}$ high, probably perennial, with numerous stems, often with their bases below the soil-surface, from the top of a taproot. Stems usually less than $1 \mathrm{~mm}$ wide, with hairs spaced, minute, broad, turgid or occasionally flat, tapering to the apex and sometimes also to the base, appressed and basifixed or subbasifixed. Leaves mostly 1-4 cm long, with 9-13 leaflets above a usually extended petiole, the leaflets obovate to narrowly obovate, sparsely pubescent on the lower surface, the upper almost glabrous, the lateral leaflets 1-7 $\mathrm{mm}$ long and 1-3 mm wide, the terminal only occasionally longer than the upper laterals, the leaflet-apex usually conspicuously retuse or emarginate, the point negligible. Stipules 1-2 mm long, deltoid, sometimes oblique with the lower part carried down the stem, the outer margin often rather erose, green, usually forming a distinct abaxial ridge, and pubescent on the outer surface and margins. Racemes $1-4 \mathrm{~cm}$ long, with 1-4 flowers of somewhat dissimilar age. Peduncle c. $0.2 \mathrm{~mm}$ wide, without a pulvinus, the flowers in the upper $1 / 4$ or less of the length, the apex often forming a stiff point, ridged with an appressed pubescence. Bracts ovate, c. $1 \mathrm{~mm}$ long. Flowers 3-5 mm long, cream or yellow, sometimes tinged pink, on, often dark, pubescent pedicels $0-2 \mathrm{~mm}$ long. Hypanthium often very slender, contracting at the apex under the fruiting calyx, the bracteoles minute. Calyx with the tube c. $1 \mathrm{~mm}$ long, gradually expanding from the hypanthium-top, appressed-pubescent, the lobes deltoid to narrow-deltoid, acute or somewhat acuminate, approximately equal to the tube, the sinuses narrow but sometimes somewhat rounded. Standard 3.5-6 mm long and 3-5 $\mathrm{mm}$ wide, tapering to the base, sometimes raised but often failing to lift or even unfold, without calli or thickenings. Wings 3-6 $\mathrm{mm}$ long, rather narrowly oblong, the apex somewhat narrowly obtuse to almost acute, the claw rather long, slender, untapered and straight, the auricle rather deep, rounded and somewhat raised, with a fold below it. Keel 4-6 mm long and 1-2 mm deep, with the apex obtuse or even recurved below an extended small acute tip, without pockets, with the upper margin straight, the auricles rather deep and rounded, the claw short, slender, untapered and somewhat recurved. Ovary c. $3 \mathrm{~mm}$ long, elliptic, curved, with appressed short or occasionally longer and looser hairs, tapering obliquely to the apex and to the base. Ovules numerous. Stipe c. $0.25 \mathrm{~mm}$ long, rather stout, glabrous. Style very slender and unthickened, scarcely tapered or flattened, often a little broader in the middle, not twisted, curved, mostly near the base, and strongly incurved at the tip, often with a 
tuft of hairs behind the tip, the beard absent. Fruit mostly $10-25 \mathrm{~mm}$ long and $3.5-4$ $\mathrm{mm}$ wide, narrowly elliptical or wider in the upper part, somewhat dorsiventrally compressed, inflated, with the suture deeply intruded, tapering at the base to a minute but distinct stipe, and at the apex to a minute narrow beaklike section behind the upcurved 1-1.25 mm style, mostly erect at maturity, dehiscent at the suture and on both sides at the tip, the pubescence of minute appressed turgid hairs, the texture thin and brittle, the surface smooth with delicate veins at $45^{\circ}$, the tissue narrow but distinct, not always closing the loculus.

In the drier parts of southern Western Australia, South Australia and far western New South Wales. On flat, loamy or sandy, often calcareous, plain. Fig. 18.

SPECIMENS EXAMINED(from c. 35 examined): Western Australia: Kanandah Station, N of Narethal, Goodall 2778, 25 June 1966 (PERTH). SOUTH Australia: on eastern foothills of Everard Range, Schodde 356, 27 Aug 1957 (AD, CANB); Maralinga, Hill 587, 12 Aug 1956 (BM, CANB); Wilgena, Mellor, June 1912 (AD, MEL, NSW). NeW SoutH WALES: Crossing Paddock, near Broken Hill, Morris 662 (AD, BRI, NSW).

\section{S. leeana J.Weber}

\section{(J.Z. Weber 1985: 301)}

TyPe: South Australia: Mt Lyndhurst, A.J.A. Sikkes 1109 \& P.Ollerenshaw, 26 Sep 1973; holo AD; iso CBG, K, NSW.

A small prostrate annual, perhaps perennial, to c. $10 \mathrm{~cm}$ high, with numerous stems from the top of a slender taproot. Stems from less than 1 to a little more than $1 \mathrm{~mm}$ wide, ridged or almost flattened below the nodes, with rather dense, occasionally sparse, hairs, the hairs antrorsely divergent or loosely appressed, often c. $0.75 \mathrm{~mm}$ long, terete, tapering and basifixed often from below a minute tubercle. Leaves mostly 1-3 cm long, with 5-7 leaflets above a variable, usually very short, petiole, the leaflets rather broadly obovate or elliptic, the pubescence of dense fine hairs on both surfaces but often sparse on the upper, the lateral leaflets mostly 5-10 mm long and 1-3 mm wide, the terminal usually obviously larger, the leaflet-apex usually broadly obtuse, occasionally narrowly so or retuse, often with a small point. Stipules usually $3-5 \mathrm{~mm}$ long, narrow-based and very long-deltoid, green, widely spaced and not forming an abaxial ridge, and with hairs on both surfaces. Racemes $1-6 \mathrm{~cm}$ long, with 1-3 flowers of only slightly dissimilar age. Peduncle less than $0.5 \mathrm{~mm}$ wide, with a pulvinus, at least sometimes, present but obscure, with flowers in the top $1 / 4$ or less, with the tip sometimes aborted so that the peduncle ends in a short point, slightly extended below the flowers, with spreading hairs at the base, often more sparse and antrorse in the upper part. Bracts lanceolate, c. $1.5 \mathrm{~mm}$ long. Flowers 3-5 mm long, purple or (fide Weber, 1985) yellow, on pubescent pedicels c. $1 \mathrm{~mm}$ long. Hypanthium short and narrow, little, if at all, contracting at the apex under the fruiting calyx, the bracteoles minute. Calyx with the tube somewhat less than $1 \mathrm{~mm}$ long, gradually expanding above the hypanthium-top, with fine antrorse rather spreading, sometimes dark, hairs, the lobes long-deltoid and rather variably attenuate, often about twice as long as the tube, not very dissimilar, the sinuses narrowly to quite broadly rounded. Standard c. $4 \mathrm{~mm}$ long and c. $5 \mathrm{~mm}$ wide, often failing to lift, tapering to a very short claw, without calli or thickening at the base. Wings c. $4 \mathrm{~mm}$ long, long-deltoid, tapering to a narrowly rounded apex, the claw very short, slender, tapering and somewhat curved, the auricle deep, shortly rounded and directed backwards. Keel c. $5 \mathrm{~mm}$ long and 1.5 $\mathrm{mm}$ deep, with the apex obtuse but with a minute lip at the tip, with the upper margin with a shallow upward curve from the tip to the rather deep and long backwardly directed auricles, without definite pockets, the claw rather short, somewhat 
tapered, straight. Ovary c. $3 \mathrm{~mm}$ long, somewhat obliquely ovoid-elliptic, densely appressed-pubescent, rather obliquely tapering at the apex and more abruptly and more obliquely at the base. Ovules numerous. Stipe c. $0.5 \mathrm{~mm}$ long, rather broad and glabrous. Style suddenly tapering from a very shortly broad base and then very gradually to a slender tip, not thickened in the lower c. 1/3 but slightly thickened flattened and pale above this, not twisted, curved rather strongly towards the base and slightly above, the tip very slender and slightly incurved or inflexed, with a few hairs behind it, the beard irregular below but more dense, although short, near the apex and on the tip. Fruit mostly 8-10 $\mathrm{mm}$ long and 5-7 mm wide, broadly ellipticoblong, with the suture somewhat intruded though much inflated, usually somewhat dorsiventrally compressed, rounded at the base above a short slender stipe and at the apex behind the $c .1 .5 \mathrm{~mm}$ recurved style, erect at maturity, dehiscent on both sides and at the tip, with loosely appressed hairs, the texture very thin and soft, the veins very delicate, at c. $90^{\circ}$, the tissue even, very shallow, a little deeper in the centre, i.e. almost absent, the loculus often not closed.

Scattered through eremean Western Australia and north of the Flinders Ranges in South Australia. In dry stony soil or clay-loam, in tussock grassland, saltbush and mulga woodland. Fig. 18.

Selected spectmens (from 8 examined): Western Australia: c. $18 \mathrm{~km} \mathrm{NE}$ of Mt Marsh, c. $95 \mathrm{~km}$ E of Wittenoom, Newbey 10237, 29 June 1984 (PERTH); Belele Station, Woombade paddock, NW of Meekatharra, Goodall 3227, 22 Aug 1965 (PERTH); Kalgoorlie, Lints 18, 2 July 1968 (PERTH); Wingellina, Kuchel 62B, 31 July 1962 (AD). SOUTH AustraLiA: Moro Gorge, c. $20 \mathrm{~km}$ S of Balcanoona, Whibley 4040, 13 Sep 1973 (AD).

\section{Group 8}

1 Plants low-growing; stipules forming an abaxial ridge; peduncle with a pulvinus

2 Leaflets usually fewer than 10; upper keel-margins with shallow lobes

46. S. parviflora

2* Leaflets usually more than 10 ; upper keel-margins without lobes

47. S. monticola

$1^{*}$ Plant ascending or erect; stipules with or without an abaxial ridge; peduncle with or without a pulvinus

3 Pedicels $2 \mathrm{~mm}$ or less in length; ovary-stipe broad or narrow; peduncle with or without a pulvinus

4 Plant with a stout stock; stipules forming an abaxial ridge; peduncle without a distinct pulvinus

48. S. recta

4* Plant with a slender taproot; abaxial ridge absent; peduncle with a distinct pulvinus

49. S. similis

$3^{*}$ Pedicels c. $3 \mathrm{~mm}$ long; ovary-stipe narrow; peduncle without a pulvinus

50. S. extrajacens

46. S. parviflora Benth.

(G. Bentham 1864: 223)

TYPE: QuEENSLAND: Wide Bay, Bidwill 105; holo K (2 sheets).

A procumbent low-growing perennial with several slender stems arising irregularly from a stout irregular underground stock. Stems slender, from less than 1 to c. $2 \mathrm{~mm}$ 
wide, rather strongly ridged or ribbed, at least when young, from the nodes, with sparse, minute, turgid or flat, occasionally broad, pointed, appressed or occasionally lifted basifixed or sub-basifixed hairs. Leaves usually less than $5 \mathrm{~cm}$ long, occasionally longer, with 5-9 leaflets above a somewhat extended petiole, the leaflets very narrowly elliptic to narrow-lanceolate or -oblong, the pubescence often sparse, appressed and only on the lower surface, the lateral leaflets uniform, mostly $10-25 \mathrm{~mm}$ long and 1-2 $\mathrm{mm}$ wide, the terminal often much longer, the leaflet-apex long-tapering to a point, or narrow but broadly obtuse behind a point. Stipules 1-2 mm long, obliquely acuminate-deltoid, sometimes with the margins erose, green, forming an abaxial ridge and with sparse hairs on the outer surface. Racemes 8-c. $20 \mathrm{~cm}$ long, with 3-10 flowers of only slightly uneven age. Peduncle $0.5-1 \mathrm{~mm}$ wide, with a conspicuous, often dark, pulvinus, with flowers in the top $1 / 3$ or less of its length, strongly ribbed, usually glabrous below and with minute, often turgid, loosely appressed hairs in the upper part. Bracts ovate, c. $1 \mathrm{~mm}$ long. Flowers purple (fide Beadle), 5-6(-8) mm long, on densely, often dark-, short-pubescent pedicels 2-4 mm long. Hypanthium short, contracted at the apex under the fruiting calyx, the bracteoles minute. Caly $x$ with the tube 1-2 mm long, variably expanding, often almost inflated above the hypanthium, with a very short appressed pubescence, sometimes rather sparse in the lower part, but dense on the lobes, usually dark at least in part, the lobes deltoid, sometimes narrowly acuminate at the apex, equal to or a little longer than the tube, the upper often shorter and narrower, the sinuses very broadly rounded. Standard 5-9 $\mathrm{mm}$ long and 6-11 mm wide, at the base rounded or curving upward to a somewhat tapered claw, without thickening or with a little irregular thickening near the base. Wings 5$8 \mathrm{~mm}$ long, obovate, or almost oblong, the apex very broadly expanded or, if less so, still very broadly obtuse, the claw short, tapered and curved, the auricle deep and usually long, rounded or deltoid, and often raised or twisted. Keel 5-8 mm long and 2.5-3 mm deep, with the apex variably but distinctly acute, with the upper margin raised behind the tip then curved a little downward, forming a distinct short upward curve (lobe), before curving downward behind the auricles, without pockets, or with folds near the auricles, the claw rather long and tapering, the auricles long and narrowly deltoid. Ovary $2.5-3 \mathrm{~mm}$ long, obliquely ovoid, curved, with a minute appressed pubescence over much of its surface but often absent near the apex, tapering, sometimes suddenly, to a slender apex below the style-base, and suddenly and obliquely tapering at the base. Ovules numerous. Stipe $0.5 \mathrm{~mm}$ long, stout, glabrous. Style c. $4 \mathrm{~mm}$ long, slender, terete and unthickened only near the base, above flattened and at least somewhat thickened, tapering a little in the upper part where truncate or abruptly narrowed with a strongly curved or geniculate (often anvilshaped) lateral tip, with a tuft of hairs on it and the truncate end, variably extended, not twisted, curvature very slight above the strongly curved base, the beard along most of the length but short, and often sparse. Fruit not seen mature.

In higher parts of south-eastern Queensland and north-eastern New South Wales. In well-watered grassland. Fig. 19.

SPECIMENS EXAMINED (from 13 examined): QuEensLAND: Mt Perry, Keys 602 (BRI); 'Narayen', near Mundubbera, Hacker 532, 24 Nov 1983 (BRI); Silverwood, near Warwick, White 1724, Sep 1922 (BRI, MEL, NSW). New South WALEs: Deepwater, Boorman NSW 218, Oct 1901 (NSW); Cherry Hill, Armidale, Roe 551, 16 Feb 1945 (CANB).

\section{S. monticola Cunn. ex Benth.}

(G. Bentham 1864: 223)

TYPE: New SOUTH WALES: Blue Mountains, A. Cunningham; lecto (fide Lee 1948: 249) K. 
A low-growing perennial with many ascending stems, often with their bases underground, arising from a very stout stock. Stems slender, from less than 1 to $2 \mathrm{~mm}$ wide, ridged or somewhat angled from the nodes, with sparse short, turgid or flat, loosely appressed, basifixed or subbasifixed hairs. Leaves mostly 5-10 cm long, with 11-25 leaflets above a short or somewhat extended petiole, the leaflets oblong, narrowly obovate or elliptic, with sparse appressed hairs on the lower surface, the lateral leaflets $2-15 \mathrm{~mm}$ long and from less than 1 to $3 \mathrm{~mm}$ wide, the terminal variable in relation to the shorter upper laterals, the leaflet-apex obtuse to deeply emarginate, with a minute point. Stipules $2-$ c. $10 \mathrm{~mm}$ long, mostly long-narrow-deltoid, with the margins irregular, green, often forming an abaxial ridge, and with sparse hairs, more sparse on the inner surface. Racemes $5-20 \mathrm{~cm}$ long, with 3-c. 15 flowers of only slightly uneven age. Peduncle $0.5-1 \mathrm{~mm}$ wide, with a conspicuous, often dark, pulvinus, with flowers in the top $1 / 3$ of its length, strongly ribbed, with scattered, minute, loosely appressed hairs, more dense in the upper part. Bracts narrowly ovate, c. $1 \mathrm{~mm}$ long. Flowers purple, 4-7 mm long, on pedicels densely pubescent with short, turgid, dark hairs and 2-3 mm long. Hypanthium short and often slender, often tending to contract under the fruiting calyx, the bracteoles minute. Calyx with the tube 1.5-2 mm long, often somewhat scarious and inflated above the hypanthium, with a short, appressed, often dark, pubescence, frequently sparse in the lower part, the lobes almost equal, shortly deltoid and long-acuminate, equal to, to much shorter than the tube, the sinuses rounded and broad, especially at the top. Standard 6-8 $\mathrm{mm}$ long and 7-9 $\mathrm{mm}$ broad, tapering or contracting to a tapering claw, without thickening. Wings 6.5-7 mm long, suboblong, the apex somewhat expanded and broadly obtuse and slightly oblique (the upper part longer), the claw short, tapered and curved, the auricle rather deep, somewhat raised, rather long, rounded-deltoid and twisted. Keel c. $7 \mathrm{~mm}$ long and 2-2.5 $\mathrm{mm}$ deep, acute, with the upper edge quite strongly curved, with shallow pockets near the auricle, the claw slender, without much taper, the auricles long, deep and rounded. Ovary 2-3 mm long, obliquely ovoid, curved, with minute appressed hairs usually only on the distal part, long-tapering to the stylebase, obliquely contracted at the base. Ovules numerous. Stipe less than $0.5 \mathrm{~mm}$ long, broad, glabrous. Style slender, rather thin-textured or sometimes stiffened in the upper part, laterally compressed above the terete base, scarcely tapering to a strongly curved tip, or a truncate tip with a lateral (geniculate) extension, with a short tuft of hairs on the curved or truncate part behind the tip, not twisted, the curvature strong at the base but slight above, the beard sparse, sometimes only in the upper part. Fruit variable, 8-15 mm long and 4-7 $\mathrm{mm}$ wide, oblong to elliptic, inflated but often strongly dorsiventrally compressed, with the suture usually widely intruded, at the base rounded above a negligible stipe, at the apex obtuse with a narrow and very small beak at the tip bearing the c. $3 \mathrm{~mm}$ recurved style, or somewhat attenuate with the beak more conspicuous and the whole apex curving; becoming erect at maturity, the dehiscence not observed, almost glabrous, the texture thin and stiff, the veins delicate, sometimes raised, at $60^{\circ}-90^{\circ}$, the tissue short and ragged.

Mostly on the tablelands and central coastal area of New South Wales. In grassland or open woodland, often on rocky slopes. Fig. 19.

Selected specimens (from c. 45 examined): New Solth Wales: Gunnedah, Betche, 17 Oct 1886 (MEL, NSW); Bathurst, Deane, Nov 1886 (NSW); Cow Pastures, Brown 4165 (BM, CANB, K, NSW); Kambah Pool, Briggs 2073, 15 Oct 1986 (AD, BRI, CANB, CBG, HO, MEL, NSW); Michelago, McKee, 23 Oct 1960 (K, NSW). 


\section{S. recta A. Lee}

\section{(A.T. Lee 1948: 250)}

TYPE: VICTORIA: Wangaratta, M. Henly, Nov 1891; holo MEL; iso MEL, NSW.

An erect or ascending perennial to $c .20 \mathrm{~cm}$ high, with one to several rather slender stems arising from a very stout stock. Stems $1-2.5(-3) \mathrm{mm}$ wide, ribbed or somewhat angled below the nodes, with sparse, often flat, minute, antrorsely divergent, basifixed or subbasifixed hairs. Leaves mostly $3-6 \mathrm{~cm}$ long, with 5-13 leaflets above a short or somewhat extended petiole, the leaflets mostly very narrowly linear-lanceolate, broader and more obtuse near the base of the plant, with a sparse pubescence usually restricted to the lower surface, the lateral leaflets uniform, mostly $10-20 \mathrm{~mm}$ long and $1 \mathrm{~mm}$ or less in width, but occasionally to 2 or $3 \mathrm{~mm}$, the terminal often up to half as long again, the leaflet-apex long-tapering, with an, often stiff, point, occasionally narrowly obtuse or emarginate. Stipules $2-c .10 \mathrm{~mm}$ long, mostly long and narrow-deltoid and with the margins often irregular, forming a distinct abaxial ridge and with scattered hairs near the margin. Racemes $8-25 \mathrm{~cm}$ long, with c. 6 to more than 25 flowers of slightly uneven age. Peduncle $0.5-1.5 \mathrm{~mm}$ wide, lacking a distinct pulvinus, with flowers usually in the upper half or less of its length, strongly ribbed, almost glabrous or with scattered minute appressed hairs more dense in the upper part. Bracts broad-ovate, 1-2 mm long. Flowers purple, 5-8 mm long, on pedicels densely pubescent with short, often dark, hairs and 1-2 mm long. Hypanthium narrow, only slightly contracting under the fruiting calyx, the bracteoles minute, broad. Calyx with the tube 2-2.5 mm long, much expanded and somewhat scarious and inflated above the hypanthium, with a minute appressed pubescence, variable in amount and often sparse, often dark, the lobes deltoid and acute to long-acuminate, usually less than half as long as the tube, almost equal, the sinuses, especially the upper, broad and rounded. Standard 7-11 $\mathrm{mm}$ long and approximately the same in width, contracting to a long slender much-tapered claw, with narrow angled ridges at the base. Wings (Fig. 4) 5-9 mm long, broadly obovate, the apex much expanded and very shortly obtuse, the claw rather long, much tapered and strongly curved, the auricle large, raised and rounded and rather twisted. Keel (Fig. 5) 6-7 mm long and 2-2.5 mm deep, with the apex acute with a somewhat projecting lipped tip, usually with swelling below, i.e. behind the apex, with the upper margin incurved but with a broad shallow raised section behind the tip, and with deep pockets toward the base, the claw long, slender, without much taper and straight, the auricles deep long and rounded-deltoid. Ovary 2-3 mm long, elliptic, with minute appressed hairs on the sutural side, usually only near the distal end but often spreading towards the apex; tapered at the apex toward the style-base and obliquely at the base. Ovules perhaps about 12. Stipe c. $0.5 \mathrm{~mm}$ long, slender, glabrous. Style slender, somewhat thickened, strongly laterally compressed above a very short terete basal section, scarcely tapered to a truncate straight or slightly curved tip with a tuft of hairs, often minute, close behind it, not twisted, the curvature strong at the base but very shallow above this, the beard usually restricted to the upper half where rather antrorse and dense. Fruit 5-10 mm long and 4-5 mm wide, almost spherical to obovoid-oblong, much inflated, not or scarcely dorsiventrally compressed, the suture not intruded, at the base rounded obliquely above a minute stipe, at the apex rounded obliquely behind a minute straight or upturned beak bearing the recurved c. $4 \mathrm{~mm}$ style, pendulous at maturity, readily dehiscent from both sides at the apex, almost glabrous, the texture very stiffly leathery, the veins somewhat raised or obscure, at $90^{\circ}$, the tissue short and ragged.

On the central and southern Western Slopes and Tablelands of New South Wales and in adjacent parts of Victoria. In grassland and open woodland, often on stony hillsides. Fig. 19. 
Selected sPecimens (from c. 45 examined): New South Wales: Wellington, Betche, 6 Oct 1886 (HO, NSW); Mudgee, Deane, Oct 1885 (NSW); between Carcoar \& Canowindra, Moore, Oct 1888 (K, NSW); Wagga Wagga, Helms, 11 Oct 1900 (NSW). Victoria: near Murchison East, Mather, 22 Sep 1903 (MEL).

49. S. similis J. Thompson

(J. Thompson 1990: 2)

TYPE: NEW SOUTH WALES: North Western Plains: 4 miles $(6 \mathrm{~km}) \mathrm{SW}$ of Brewarrina on Tarcoon road, J. Thompson, 5 Sep 1968; holo NSW 87222; iso NT.

S. parviflora var. vestita C. White \& Francis (C.T. White \& W.D. Francis 1926: 156). Type: Queensland: near Adavale, MacGillivray, 28 Aug 1923; holo BRI; iso AD, NSW.

An erect or ascending perennial to $c .25 \mathrm{~cm}$ high, with numerous slender stems from the top of a narrow taproot, the stem-bases below the soil-surface and often branching there. Stems $0.5-1.5 \mathrm{~mm}$ wide, somewhat angled below the nodes with sparse minute, flat or rather turgid, appressed, basifixed or subbasifixed hairs. Leaves $0.5 \mathrm{~cm}$ long, with 5-15 leaflets above a somewhat, often much-extended petiole, the leaflets in general elliptic, broader and more obtuse near the base of the plant, the appressed pubescence usually sparse and confined to the lower surface, the lateral leaflets usually 5-8 (occasionally more than 20 ) $\mathrm{mm}$ long and from less than 1 to $2 \mathrm{~mm}$ wide, the terminal variable, often longer than the laterals, the leaflet-apex obtuse or acute, rarely retuse, with a short point. Stipules 1-6 $\mathrm{mm}$ long, deltoid to very long-narrowdeltoid, the margins irregular, green or pale below, often not forming an abaxial ridge (but with the petiole tending to form a joint), and with sparse hairs on both surfaces. Racemes 10 to almost $25 \mathrm{~cm}$ long, with 5-15 flowers of almost even age. Peduncle $0.5-1.5 \mathrm{~mm}$ wide, usually with a distinct dark and pubescent pulvinus, with flowers on less than $1 / 2$, often $1 / 3$, of its length, strongly ribbed with scattered, minute appressed or divergent hairs, often dark and often dense on the upper parts. Bracts ovate, c. $1 \mathrm{~mm}$ long. Flowers purple, $6-7 \mathrm{~mm}$ long, on, sometimes dark, pubescent pedicels $0.5-1.5 \mathrm{~mm}$ long. Hypanthium short and narrow, tending to contract at the apex under the fruiting calyx, the bracteoles minute. Calyx with the tube c. $2 \mathrm{~mm}$ long, much expanded and somewhat scarious and inflated above the hypanthium, with an often sparse, minute, often dark, appressed pubescence, the lobes acuminatedeltoid and variably attenuate, usually almost equal to, occasionally longer than, the tube, almost equal, the sinuses broad and rounded. Standard 7-11 mm long and as wide or a little less in width, contracting to a rather long-tapering claw, with or without slender ridges or an amorphous thickening near the base. Wings 5.5-9 mm long, broadly obovate, the apex much expanded and very shortly obtuse, the claw rather long, tapered and strongly curved, the auricle large and raised, roundeddeltoid and twisted. Keel 5.5-7 $\mathrm{mm}$ long and $2.5 \mathrm{~mm}$ deep, with the apex acute with a narrow beaklike tip and swellings behind and below it, with the upper margin strongly incurved but with shallow lobes behind the tip, and with deep pockets toward the base, the claw long, slender without much taper and straight, the auricles long and deep and rounded to somewhat deltoid. Ovary 2-2.5 mm long, ellipticovoid, with minute hairs over most of the surface but sometimes absent from the lower (non-sutural) side, tapered at the apex towards the style-base and rather obliquely at the base. Ovules numerous. Stipe $0.5 \mathrm{~mm}$ long, stout, glabrous. Style broad and terete at the base, above laterally compressed and somewhat stiffened with a conspicuous central groove, scarcely or not tapered behind an obliquely truncate tip with a minute tuft behind it, not twisted, the curvature strong at the base with little above, the beard only in the upper part where antrorse and dense. Fruit 6-15 mm 
long and 5-8 mm wide, shortly ovoid or oblong-elliptic to almost round, inflated but dorsiventrally compressed, with the suture intruded, at the base rounded above, or tapering to, a minute stipe, at the apex broadly and obliquely rounded below a short inset straight or erect beak below the recurved, c. $3 \mathrm{~mm}$ style; spreading to at least above the horizontal at maturity, dehiscing at the suture, minutely pubescent, the texture thin but stiff, the veins a little raised, at $45^{\circ}-60^{\circ}$, the tissue short or minimal, becoming ragged.

On the plains of south-western Queensland and northern and central western New South Wales. In red soil, in grassland or open woodland. Fig. 19.

The slight discrepancy in several minor features between specimens from New South Wales and those from Queensland (as represented by the Type of S. parviflora var. vestita) may be enhanced by further collections. I hesitate to distinguish two taxa with the material available.

SELeCTED SPECIMENS (from 10 examined): QueENSLAND: $117 \mathrm{~km}$ SSE of Charleville, Everist 5014, 29 Apr 1952 (BRI); 82 miles [130 km] E of Cunnamulla on road to Bollon, Phillips 006848, 25 Sep 1963 (CBG). New South Wales: Bourke district, McDougall NSW 234 (NSW); $8 \mathrm{~km} \mathrm{~N}$ of Nymagee on the Cambelego road, Cunningham 826, 18 Aug 1973 (NSW); near Mt Hope, Gauba 006492, 23 Oct 1956 (CBG).

\section{S. extrajacens J. Thompson}

\section{(J. Thompson 1990: 3)}

TyPe: New South Wales: 'Narriearra', L. Richley SCS1482, 4 July 1974; holo NSW.

An erect, apparently annual, plant from $10-c .30 \mathrm{~cm}$ high, with one to several stems and a taproot. Stems mostly $2-4 \mathrm{~mm}$ wide, strongly ridged or angled from the nodes, the hairs rather sparse, $0.75 \mathrm{~mm}$ long, very slender and with a fine tip, flat, basifixed and mostly spreading, sometimes curved-antrorse, often irregularly twisted or crisped. Leaves 3-15 cm long, with 9-25 leaflets (fewer on younger plants) above a somewhat extended petiole, the leaflets ovate to ovate-elliptic with a loose pubescence often restricted to the margins on the upper surface, the lateral leaflets mostly $10-15 \mathrm{~mm}$ long and 2-5 mm wide (often wider at the base of the plant), the terminal variable in relation to the short upper laterals, usually a little longer, the leaflet-apex retuse to emarginate, often recurved with a short point. Stipules c. $5 \mathrm{~mm}$ long, mostly narrowly lanceolate above a broad base, green, not forming an abaxial ridge, the pubescence on both surfaces but mostly near the margins. Racemes $5-c .15 \mathrm{~cm}$ long, with c. 5-10 flowers of somewhat uneven age. Peduncle 1-2 mm, occasionally less, in width, the pulvinus absent, with flowers in the upper $1 / 2$ or sometimes $1 / 3$, usually ribbed or angled, with a sparse spreading pubescence often more antrorse and dense in the upper part. Bracts broadly lanceolate, c. $2 \mathrm{~mm}$ long. Flowers purple, 6-8 $\mathrm{mm}$ long, on densely, often partially dark, pubescent pedicels c. $3 \mathrm{~mm}$ long. Hypanthium rather narrow, somewhat contracted at the apex under the fruiting calyx, the bracteoles obvious but very slender. Calyx with the tube c. $2 \mathrm{~mm}$ long, obliquely and rather suddenly expanding above the hypanthium, with moderately dense spreading or antrorse, often dark, hairs, the upper lobes shorter than the tube, slightly broader and shorter than the lower, the sinuses broad and rounded. Standard 8-9 mm long and 9$10 \mathrm{~mm}$ wide, tapering suddenly to a broad tapered claw, with a two-lobed high thickening above a concave area near the base. Wings 7-8 $\mathrm{mm}$ long, obovate, the apex very shortly obtuse, the claw not very long, very slender and curved, the auricle deep, rounded and somewhat recurved and twisted. Keel 6-8 mm long and c. $2.5 \mathrm{~mm}$ deep with the apex narrowly acute and upcurved so that the narrow beak-like tip is well inside the end, the apex below the tip somewhat inflated, with the upper margin 
strongly downcurved, and with the pockets small and distinct, the claw long, slender and straight, the auricles large rounded and directed backward. Ovary c. $3 \mathrm{~mm}$ long, very narrowly ovoid, glabrous or with a few long hairs near the base, tapering gradually to a narrow apex and suddenly and obliquely at the base. Ovules numerous but few developing. Stipe c. $0.5 \mathrm{~mm}$ long, slender, glabrous. Style tapering slightly and evenly from a rather broad base that extends above the ovary-tip, laterally flattened but not much thickened, not twisted, curved strongly especially the lower part, the tip not very narrow with the stigmatic end as broad, sometimes bent to one side with a closely forwardly directed tuft or line of minute hairs just behind the stigmatic area, the beard sparse on the lower part but short, dense and antrorse in the upper 1/3. Fruit not seen mature, immature fruit c. $20 \mathrm{~mm}$ long and c. $6 \mathrm{~mm}$ wide, curvedelliptic, somewhat inflated either side of the intruded suture, at the base shortly tapering and virtually sessile, at the apex tapering to a short, narrow, stiff, straight beak behind a c. $3 \mathrm{~mm}$ strongly recurved style, pendulous at maturity, the dehiscence probably along the suture, almost glabrous, soft in texture, the surface almost smooth with the slightly raised veins at c. $60^{\circ}$ or less, the tissue deep, probably closing the loculus.

In the north-western corner of New South Wales and the north-eastern corner of South Australia. The few field notes indicate a species of clay-loam floodplain with annual saltbush. Fig. 19.

Selected SPECimens (from c. 10 examined): South Australia: c. $25 \mathrm{~km} \mathrm{~S}$ of Moolawatana Station, Kuchel 881, 22 Aug 1963 (AD); North Mulga Bore O.S., $14.5 \mathrm{~km} \mathrm{~N}$ of Paralana Springs turn-off, Symon 5992, 23 Aug 1968 (AD, CANB, K). NEw South WALES: $48 \mathrm{~km} \mathrm{~N}$ of Tibooburra, Sturt National Park, Conrick 652, 5 Sep 1981 (AD); Mt King, Mulham W629, 24 Sep 1973 (NSW); 'Horton Park', Wood 4, Aug 1967 (NSW).

\section{Group 9}

1 Ovary and fruit glabrous

2 Leaves usually with 7-25 leaflets; style-tip narrowing from the top with the narrowed piece variously extended

51. S. affinis

2* Leaves usually with 21-41 leaflets; style-tip usually truncate 52. S. microphylla

$1^{*}$ Ovary and fruit pubescent

3 Racemes $10-40 \mathrm{~cm}$ long

53. S. lessertiifolia

$3^{*}$ Racemes $5 \mathrm{~cm}$ or less in length

54. S. novae-zelandiae

\section{S. affinis (A. Lee) J. Thompson}

(J. Thompson 1990: 2)

BASIONYM: S. microphylla subsp. affinis A. Lee (A.T. Lee 1948: 256).

TYPE: NeW SOUTH Wales: Northern Far Western Plains: Dunlop Station, W side of the Darling River, Etheridge, 10 July 1903; holo NSW.

S. microphylla subsp. pallescens A. Lee, op. cit., 255. TYPE: QuEENSLAND: Herberts Creek, Bowman; holo MEL; iso NSW.

S. microphylla subsp. glabrescens A. Lee, loc. cit. quoad typum. TYPE: WESTERN AUSTRALIA: near Barrow Range, Camp 33, Elder Expl. Exped., R. Helms; holo NSW 717; iso AD (partim). 
A prostrate perennial to c. $25 \mathrm{~cm}$ high, with numerous stems, often with their bases below the soil-surface, from the top of a taproot. Stems $1-4(-8) \mathrm{mm}$ wide, often strongly flexuose, strongly ridged from the nodes, sparsely to densely pubescent, the hairs sometimes minute but often $0.5 \mathrm{~mm}$ or more in length, basifixed or subbasifixed, flat or turgid, sometimes elliptic, often tapering to a narrow tip, and mostly appressed but sometimes crisped and irregularly so, or divergent. Leaves very variable but mostly 3-10 cm long, with 7-25 leaflets above a short to long-extended petiole, the leaflets mostly 5-15 mm long and 3-8 $\mathrm{mm}$ wide, very variable on the plant and largest at the base of the plant, and, in each leaf, the upper much smaller than the lower, usually broadly elliptic, glabrous or with appressed or loosely antrorse hairs on the lower surface, the terminal variable but mostly not very dissimilar to the small upper laterals, the leaflet-apex usually deeply emarginate but occasionally shallowly so or rounded. Stipules from 1 to c. $10 \mathrm{~mm}$ long, obliquely ovate or with a broad thin and scarious base, often tending to extend down the stem, and a narrow green long-acuminatedeltoid upper part, with the margin irregular, occasionally toothed, with the formation of an abaxial ridge variable and with hairs almost restricted to the margins. Racemes 2-c. $30 \mathrm{~cm}$ long, with 5 to more than 35 flowers of very dissimilar age. Peduncle from less than 0.5 to $4 \mathrm{~mm}$ wide, without a pulvinus, with flowers occupying $1 / 2$ to $1 / 3$ or even more of its length, strongly ribbed, usually sparsely pubescent. Bracts lanceolate, 1-2 mm long. Flowers purple, pink, yellow or white, 6-10 mm long, on, sometimes dark-pubescent, pedicels 1-1.5 mm long. Hypanthium often broad, but variable, not contracting at the apex under the fruiting calyx, the bracteoles narrow, often minute. Calyx with the tube $1.5-3 \mathrm{~mm}$ long, obliquely expanding above the hypanthium but remaining rather narrow, glabrous or sparsely or densely pubescent, the lobes deltoid or variously shortly, rarely long-, acuminate, about equal in length to the tube or the shorter upper lobes shorter, the sinuses broad. Standard 6-11 $\mathrm{mm}$ long and 6-12 mm broad, rounded or shortly tapering above a short tapered claw, sometimes with variably developed vertical thickenings at the base. Wings 5-11 mm long, curved-obovate, the apex broad and obtuse, the claw rather long, tapered and curved, the auricle deep, rounded and recurved, with a twist below and in front of it. Keel 6-11 mm long and 2.5-3.5 mm deep, usually obtuse with the apex sometimes slightly extended or retracted, with the upper margin almost straight and with big pockets, the auricles large, deltoid and raised or pointing backward, the claw short, slender, tapered and slightly recurved. Ovary 3-5 $\mathrm{mm}$ long, narrowly ovoid, glabrous, shortly and very obliquely tapering at the base and more gradually tapering to the slender apex. Ovules numerous. Stipe c. $0.5 \mathrm{~mm}$ long, glabrous. Style scarcely tapering from the narrow base, curved near the base and at the apex but more shallowly or without curving between, not twisted, unthickened and terete near the base but somewhat flattened and a little stiffened in the upper 2/3, the apex narrowing from the top with the narrowed piece variously extended, with a strong antrorse arc of hairs at the back and hairs extending forward onto the tip, the beard sparse and varying from along the whole length to only on the upper part. Fruit (Fig. 7) 5-11 mm long and 4-7 mm wide, broadly oblong, obovoid or spherical, much inflated but sometimes somewhat flattened on the sutural side where often much indented, with the base contracting to a narrow section above a minute stipe, and with the apex usually broadly rounded below or behind a short but variably developed, often very slender, erect beak bearing the recurving, $2.5-4.5 \mathrm{~mm}$ long style, from erect to pendulous at maturity, sometimes dehiscing at the apex on both sides but usually indehiscent, the surface glabrous, the texture varying from papery and thin to very stiff, the venation variously, sometimes conspicuously, raised, at c. $60^{\circ}$, the tissue variable in depth, deepest in the centre and absent from the sides, not closing the loculus.

Widespread in inland Australia southward of the tropic, extending northward especially in the Northern Territory. Usually in red sandy loam, often with Mulga and Callitris. Fig. 20. 
Lee (1948) observed the characteristic style of S. affinis but did not consider this taxon to be specifically distinct from S. microphylla. Her treatment of $S$. microphylla subsp. glabrescens shows that she did not observe the significant difference between her Type specimen, with its affinis-type style and leaflet number, and the other specimens cited that fall within the distinct, numerous-leafleted species S. microphylla. Her S. microphylla subsp. pallescens falls well within $S$. affinis and has not been maintained.

SELECTED SPECIMENS (from c. 430 examined): WESTERN Australia: 15 miles [24 km] E of Kalli, Speck 1036, 22 July 1958 (AD, CANB, NSW). NORTHERN TERRITORY: Annitowa Station, Latz 7005, 9 May 1977 (AD, BRI, CANB, NSW, NT). South Australia: c. $100 \mathrm{~km}$ E of Dalhousie Springs, Lothian 1717, 11 Aug 1963 (AD, NSW). QueEnsLand: Cheepie-Quilpie road, Williams 78124, 14 Aug 1978 (BRI). New SOUTH W WLES: 16 km from Byrock on Gongolgon road, Thompson 1907, 31 Aug 1973 (NSW).

\section{S. microphylla A. Gray}

\section{(A. Gray 1854: 410)}

Type: New South WaLes: Central Western Slopes: Hunters River district and Puen Buen, U.S. Exploring Expedition; holo US, n.v., photo NSW, iso (fragment) NSW.

[S. microphylla var. tomentosa J. Black (J.M. Black 1948: 4172), nom. invalid.] S. microphylla subsp. tomentosa A. Lee (A.T. Lee 1948: 259). TYPE: NeW SOUTH WALES: Central Western Slopes: Narromine, J.H. Maiden NSW 729, Sep 1898; holo NSW.

[S. microphylla var. minima J. Black (J.M. Black 1948: 472), nom. invalid;] S. microphylla subsp. minima A. Lee, loc. cit. TyPE: VICTORIA: Banks of Murray R. at Red Cliffs Pumping Station, J.H. Willis, 18 Aug 1948; holo MEL.

A usually prostrate perennial, occasionally forming large clumps c. $60 \mathrm{~mm}$ or more high, with branched stems usually from a taproot but occasionally from a more irregular stock, the stem-bases often below the soil-surface. Stems $1-\mathrm{c}$. $6 \mathrm{~mm}$ wide, often very flexuose, often with strong ridges from the nodes, sparsely to densely pubescent, the hairs mostly $0.5 \mathrm{~mm}$ long, flattened, sometimes turgid, or terete, usually tapering to a narrow tip, from antrorsely appressed to spreading widely, and basifixed with the base often on a minute tubercle. Leaves very variable but usually $5-$ $15 \mathrm{~cm}$ long, with (15-)21-41 leaflets above an often-extended petiole, the leaflets mostly 1-5 mm long and usually $1-c .3 \mathrm{~mm}$ wide, the upper, in each leaf, much shorter than the lower, most shortly and broadly cuneate, occasionally almost orbicular or even wider than long, frequently deciduous, occasionally glabrous but usually with appressed or spreading hairs at least on the lower surface, often on both, the terminal not very dissimilar to the small upper laterals, the leaflet-apex mostly retuse, with or without a point. Stipules c. $1-$ c. $4 \mathrm{~mm}$ long, with a very broad and scarious base and an upper narrow, often very narrow, green part that is usually linearlanceolate and acuminate, with irregular margins and occasional minute teeth, not forming an abaxial ridge, and with hairs almost restricted to the margins. Racemes usually 10-25 cm long, with c. 10-25 flowers of disparate age. Peduncle c. 0.5-3 mm wide, without a pulvinus, with flowers occupying from $1 / 3$ to all its length, strongly ribbed, sparsely to densely pubescent. Bracts ovate to lanceolate, 1-1.5 mm long. Flowers purple, or occasionally pink or white, 5-10 mm long, on slender densely to sparsely, and often dark, pubescent pedicels 1-2 mm long. Hypanthium variable, not contracting at the apex under the fruiting calyx, the bracteoles minute. Calyx with the tube c. $1 \mathrm{~mm}$ long, inflated above the hypanthium-top and further expanded, glabrous or with a usually short, appressed or spreading, often dark, pubescence, the lobes deltoid and usually much shorter than the tube, the sinuses broad. Standard 6$8 \mathrm{~mm}$ long and 6-9 $\mathrm{mm}$ wide, usually tapering to the base but sometimes to a tapered 
claw, with little if any thickening at the base. Wings 6-7 mm long, narrowly oblong, curved, the apex obtuse, the claw rather long and slender, slightly tapered and curved, the auricle deep and truncate with a twist below and in front of it. Keel $4.5-7 \mathrm{~mm}$ long and $2-3 \mathrm{~mm}$ wide, somewhat narrowly obtuse with a small forward projecting apex or with the apex rounded, with the upper margin almost straight between the shortly raised tip and the somewhat raised or lowered rather deep, deltoid or truncate, auricles, with pockets below the auricles, the claw rather long, slender, scarcely tapered and almost straight. Ovary $1.5-3 \mathrm{~mm}$ long, narrowly ovoid, glabrous or virtually so, shortly and rather obliquely tapering at the base and apex. Ovules numerous. Stipe c. $0.5 \mathrm{~mm}$ long, tapering, glabrous. Style scarcely tapering from the narrow base, curved near the base, and at the extreme tip but with little if any curve between, not twisted, unthickened but somewhat laterally flattened in the upper c. $2 / 3$, the apex truncate beyond a very short incurving, with an arc of stiff hairs behind the short tip, the beard sparse and only in the upper part. Fruit 5-10(-15) $\mathrm{mm}$ long and 3-8 $\mathrm{mm}$ wide, almost globular to shortly and broadly oblong, much inflated but often somewhat flattened on the sutural side with the suture variably intruded, rounded at the base above a short tapered section above the minute stipe, at the apex obliquely rounded behind or below a very short beak, of variable direction, bearing the 2-4 mm style, from erect to pendulous at maturity, sometimes dehiscing at the apex on both sides but usually indehiscent, the texture stiff to papery and usually rather thin, the surface glabrous with the veins at $\left(45^{\circ}-\right) 60^{\circ}-90^{\circ}$ and sometimes conspicuously raised, the tissue short and central, not closing the loculus.

Widespread in inland Western Australia and in the south-western part of the Northern Territory and north-eastern and north-western South Australia; also on the Eyre Peninsula and along the Murray River, extending across New South Wales to the Northern Tablelands. In light soils, usually on sandhills or on sandplain. Fig. 20.

S. microphylla differs from S. affinis in its style-tip and its very numerous leaflets. Lee (1948) mentions the numerous leaflets in her descriptions of subspp. tomentosa and minima and in her material (other than the Type specimen) of subsp. glabrescens but fails to separate the species. The pubescence on which she separated these forms as subspecies does not appear to be a consistent feature within this species and I have not recognised subspecies.

Selected sPecimens (from c. 300 examined): Western Australia: Beroo Pool, near Yelma, Toelken 6125, 13 Sep 1979 (AD, PERTH). NoRTHERN TERRITORY: Campbell Range, Latz 2087 (AD, CANB, NSW, NT, PERTH). SOUTH AustRALIA: near Pygery, near Windinna, on the road to Yardea Station, Moore, 7 Oct 1986 (AD). New SoutH WaLes: Tamworth, Rupp 7, Nov 1904 (NSW). VICTORIA: c. 3 miles [5 km] NE of Hattah, Muir 1200, 19 Aug 1960 (AD, MEL, NSW).

\section{S. lessertiifolia DC.}

\section{(A.P. de Candolle 1825a: 19)}

TYPE: in Novae Hollandiae ora australi (v.s. comm. a Mus. Par.); holo G-DC, n.v., microfiche NSW.

S. froebelii Regel (E.A. von Regel 1854: 178, t. 89). Type: grown from seed from 'Porte Adelaide [S.A.] in New Holland'. The plate is probably the type.

[The horticultural name S. astragalifolia, often added to the synonymy of this species, was never validly published.]

A decumbent subshrubby perennial, often to $60 \mathrm{~cm}$ high, with numerous, sometimes conspicuously flexuose, stems from an, often buried, stout rhizomatous stock or a 
taproot. Stems 2-4 mm wide, conspicuously ribbed, at least when young, and often ridged below the nodes, the hairs dense or sparse, occasionally minute, mostly 0.5 ($0.75) \mathrm{mm}$ long, unevenly elliptic, i.e. long-tapering to the apex, appressed to spreading, often rather irregular and twisted, flat, basifixed, subbasifixed or occasionally laterally attached near the base, with few to many dark. Leaves mostly 5-10 cm long, with 13-21 leaflets above a short to rather extended petiole, the leaflets broadly to narrowly elliptic or broader above or below the middle, with an appressed pubescence on the lower surface or glabrous, the lateral leaflets 5-20 mm long and 2-10 mm wide, the terminal variable but usually scarcely longer than the short upper laterals, the leaflet-apex usually narrowly to broadly obtuse, sometimes acute or retuse or emarginate, sometimes with a minute point. Stipules often c. $5 \mathrm{~mm}$ long, ovate-deltoid to broadly lanceolate-acuminate, with an occasional tooth, broad-based, green or scarious, with the formation of an abaxial ridge variable, pubescent on the outer surface. Racemes mostly $10-30 \mathrm{~cm}$ long, variable as to flower-number but usually with 8-20 flowers of somewhat uneven age. Peduncle $1-2 \mathrm{~mm}$ wide, without a pulvinus, with flowers in the upper $1 / 4$ or sometimes $1 / 2$, striate to somewhat angled, the pubescence variable but usually short and appressed, often dark near the top. Bracts ovate- to narrow-lanceolate, 1-4 mm long. Flowers dark- to pale-purple, occasionally white, 7-10 mm long, on densely, often dark-, pubescent pedicels 1.5-4 $\mathrm{mm}$ long. Hypanthium slender, occasionally contracting at the apex under the fruiting calyx, the bracteoles small and narrow. Calyx with the tube $2-2.5 \mathrm{~mm}$ long, obliquely but only narrowly expanding above the hypanthium, with a somewhat loosely appressed, often very dark, pubescence, the upper lobes deltoid, longer, narrower and more tapering, from much shorter to slightly longer than the tube, the lower longer, narrower and more tapering, the sinuses broad and rounded. Standard $10-11 \mathrm{~mm}$ long and 8-16 mm wide, tapering to a tapered claw, sometimes with thickened lines but usually unthickened. Wings $7-8 \mathrm{~mm}$ long, oblong and broadly and shortly obtuse, the claw rather long, very slender and somewhat curved, the auricle very deep, deltoid or shortly rounded. Keel 8-10 mm long and c. $4 \mathrm{~mm}$ deep, with the apex broad, obtuse and often very slightly twisted sideways, slightly uncurved to the rounded (i.e. the tip retracted) tip, with the upper margin with a low point in the middle, and with a long shallow fold or pocket, the claw not very long, tapering to a slender tip, the auricles long, pointing backward and rounded. Ovary 3-5 mm long, curved-elliptic, with a dense close pubescence, long-tapering at the apex to a rather broad style-base, little-tapered at the base. Ovules numerous but many failing to develop. Stipe c. $0.5 \mathrm{~mm}$ long, broad, glabrous. Style rather variably broad at the base and abruptly tapering before gradually tapering to the slender flexible and variably disposed tip, laterally compressed, not twisted, stiffened and shallowly curved in the upper 2/3, the beard long and although often sparse below, dense in the upper part and on the tip. Fruit $10-30 \mathrm{~mm}$ long and 5-8 mm wide, broadly to narrowly elliptic or broader towards the apex, much inflated but often depressed in the middle of the sutural side, the suture not intruded, tapering rather abruptly to the base or to a stipe c. $0.5 \mathrm{~mm}$ long, at the apex with a variable but usually rather strong and oblique taper to a short narrow upturned beak often bearing the recurved 4-5 mm style, most raised to near the horizontal at maturity, dehiscent near the apex and often also at the base, rarely all along the sutural side and in the upper part of the other side, with spaced closely appressed short hairs, the texture stiffly thin and after dehiscence often very stiff, the surface almost smooth but with fine raised veins at $90^{\circ}$, or a little less, the tissue variable, sometimes quite conspicuous at least in the central part of the suture, sometimes apparently absent.

Almost confined to the coast from eastern Victoria to north-western Tasmania, Kangaroo Island and the Eyre Peninsula, occasionally extending inland in South Australia and south-western Victoria. On calcareous dunes or on sea-cliffs; associated with limestone. Fig. 20. 
Selected sPecimens (from c. 325 examined): South Australia: Wilgena, White, June 1912 (AD); Lower Coorong, c. $40 \mathrm{~km} \mathrm{~S}$ of Salt Creek, Symon 10463, 9 Oct 1975 (AD, NSW). VICTORIA: London Bridge, Mornington Peninsula, Ross 2622, 31 Oct 1981 (BRI, MEL). TASMANIA: Hunters Island, Olsen, 3 Dec 1948 (HO, MEL); Woolnorth, Gunn 466/1827, 25 Nov 1836 (K, NSW).

\section{S. novae-zelandiae Hook. $f$.}

(J.D. Hooker 1867: 51)

Type: New Zealand: Sources of the Kowai River, Canterbury, Sinclair $\mathcal{E}$ Haast, 186061; holo $\mathrm{K}$.

S. novae-zelandiae var. glabra Simpson (G. Simpson 1945: 188). Type: New Zealand: Mt Ida, Central Otago, G. Simpson; holo Herb. Plant Research Bureau, Wellington, n.v.

A suberect perennial to $c .10 \mathrm{~cm}$ high, with numerous stems from a branching rhizome. Stems c. $1 \mathrm{~mm}$ wide, somewhat flexuose and ribbed, with sparse to moderately dense appressed minute and basifixed hairs. Leaves mostly less than $5 \mathrm{~cm}$ long, with 13-19 leaflets above an extended petiole, the leaflets obovate with an appressed pubescence mostly restricted to the lower surface, the lateral leaflets usually c. 3-7 $\mathrm{mm}$ long and $2-4 \mathrm{~mm}$ wide, becoming shorter towards the short and irregular terminal leaflet, the leaflet-apex obtuse or retuse. Stipules c. $2 \mathrm{~mm}$ long, ovate, green, usually forming an abaxial ridge and with few hairs. Racemes mostly less than $5 \mathrm{~cm}$ long, with up to 4 , occasionally more, flowers of rather even age, and often with flowers aborted (i.e. with superfluous bracts). Peduncle c. $1 \mathrm{~mm}$ wide, without a pulvinus, with flowers in the upper $1 / 2$ or less, somewhat ribbed, the pubescence sparse and appressed. Bracts ovate-oblong to lanceolate, $2-4 \mathrm{~mm}$ long. Flowers purple to orangebrown, c. 7-9 mm long, on densely short-pubescent pedicels 1-3 mm long. Hypanthium broad, not, or scarcely, contracting under the fruiting calyx, the bracteoles 1-2 $\mathrm{mm}$ long and somewhat oblong. Calyx with the tube c. $2 \mathrm{~mm}$ long, gradually and somewhat obliquely expanding above the hypanthium, with a sparse minute appressed pubescence, the lobes deltoid- or long-deltoid-acuminate, equal to or somewhat longer than the tube, the sinuses broad and rounded. Standard 7-8 mm long and as wide or a little wider, tapering to a tapered claw, without calli. Wings 6-7 mm long, oblong and shortly and broadly obtuse, the claw rather long, slender and curved, the auricle deep and shortly rounded. Keel c. $6 \mathrm{~mm}$ long and deep, with the apex broad and obtuse with the tip somewhat retracted, with the upper margin almost straight, and without folds or pockets, the claw tapered and not very long, the auricles long, pointing backwards and rounded. Ovary 2-3 $\mathrm{mm}$ long, elliptic, with a few to numerous spaced, appressed, minute hairs, tapering at the apex to the style-base and only a little tapered at the base. Ovules numerous but many aborted. Stipe c. 0.5 $\mathrm{mm}$ long, very broad and glabrous. Style broader at the extreme base but tapered to a slender rather straight and little-tapered region at the apex, not stiffened, not twisted, the tip slightly curved, with a few hairs behind it, the beard in the upper part. Fruit c. $20 \mathrm{~mm}$ long and $10 \mathrm{~mm}$ wide, broadly elliptic-oblong, much inflated, the suture not intruded, at the base tapering abruptly to a stipe c. $0.5 \mathrm{~mm}$ long, at the apex rounded and shortly beaked or shortly tapered to the c. $2 \mathrm{~mm}$ style or its remains, disposition at maturity not seen, dehiscent along the sutural side and on both sides near the apex, with minute spaced hairs occasionally absent, the texture stiffly thin and later very stiff, the surface almost smooth but with fine raised veins at $90^{\circ}$, the tissue inconspicuous or absent.

In the South Island of New Zealand. On high-mountain and alpine screes and stony flats. Fig. 20. 
Selected SPECIMENS (from 12 examined): Marlborough: Marlborough, Sinclair, 1850-60 (NSW). CANTERBuRY: Fowlers Pass, Amuri (NSW); Mt Winterslow, Laing (NSW); c. 30-35 km from Cass, on West Coast road, Groeneveld 99, 21 Jan 1988 (CBG); Coleridge Pass, Kirk 617 (AD).

\section{Group 10}

1 Stem-hairs basifixed or subbasifixed; style-tip geniculate

2 Plant prostrate or occasionally ascending; abaxial ridge present or absent; calyx with the sinuses usually narrow

3 Leaves of 3-7 leaflets and with the terminal leaflet much longer than the laterals; flowers not always crowded at the top of the peduncle

4 Ovary and fruit with a relatively short pubescence; fruit no more than twice as long as broad

55. S. oroboides

4* Ovary and fruit with very long hairs; fruit much longer than broad

56. S. paucifoliolata

$3^{*}$ Leaves of 5-15 leaflets, with the terminal variable in relation to the laterals; flowers crowded at the top of the peduncle

5 Calyx-lobes much longer than the tube; fruit-surface minutely tuberculate; translucent style-tissue limited to a trace

57. S. tenuis

5* Calyx-lobes scarcely longer than the tube; fruit-surface not tuberculate; translucent style-tissue well-developed

6 Abaxial ridge often absent; translucent style-tissue broad and winglike in the upper part

58. S. reticulata

6* Abaxial ridge usually present; translucent style-tissue not broad and wing-like

59. S. behriana

$2^{*}$ Plants erect or occasionally ascending; abaxial ridge absent; calyx with the sinuses rather broad

7 Stem-hairs c. $0.5 \mathrm{~mm}$ long; calyx-lobes a little shorter than the tube

60. S. campestris

$7^{*}$ Stem-hairs mostly $0.75-1.5 \mathrm{~mm}$ long; calyx-lobes a little longer than the tube

61. S. vestita

$1^{*}$ Stem-hairs medifixed; style-tip geniculate or straight

8 Keel little, if at all, longer than the wings; calyx-lobes usually equal to or shorter than the tube and acuminate-deltoid; style-tip geniculate

62. S. sericea

$8^{*}$ Keel much longer than the wings; calyx-lobes usually much longer than the tube and characteristically straight-sided; style-tip straight

63. S. phacoides

55. S. oroboides F. Muell. ex Benth.

(G. Bentham 1864: 222)

Type: New South Wales: New England (Clifton), C. Stuart 173; lecto (fide Lee 1948: 195) MEL; iso $K$.

A prostrate or ascending perennial usually less than $15 \mathrm{~cm}$ high, with many stems, often with their bases below ground, from the top of a taproot or a stout stock with subsoil plant connections. Stems mostly 1-2 mm wide, often ribbed, sometimes angled or even flattened near the nodes, the hairs usually well-separated, sometimes 
dense, c. $0.5 \mathrm{~mm}$ long, slender, somewhat flattened or virtually terete, narrow at the apex, usually straight and appressed but occasionally some lifted and even twisted, and basifixed or subbasifixed. Leaves mostly 2-7 cm long, with 3-7 leaflets above an extended petiole, the leaflets often narrowly elliptic or narrowly lanceolate but the much broader and obtuse juveniles often persisting, the pubescence appressed and on both surfaces or absent from the upper, the lateral leaflets often 10-24 mm long and 2-5 $\mathrm{mm}$ wide, the terminal much longer (up to twice as long) than the laterals, the leaflet-apex tapering and long-acute and pointed. Stipules $3-5(-10) \mathrm{mm}$ long, deltoid and acuminate to very narrowly long-deltoid, variable in the length of the narrow tip, green, not forming an abaxial ridge and pubescent on the outer surface. Racemes 5-15 cm or even more in length, with 3-c. 16 flowers of even age. Peduncle 0.5-1.5 mm wide, with the pulvinus distinct, pubescent and often dark, with the flowers usually crowded in the upper 1-2 cm, even subumbellate, but often covering c. 1/4 of the peduncle-length, ribbed, with an appressed, often sparse, pubescence that tends to be dark, more dense and more spreading near the flowers. Bracts ovatelanceolate, c. $1 \mathrm{~mm}$ long. Flowers purple, c. 6-9 mm long, on rather densely and darkpubescent pedicels up to $5 \mathrm{~mm}$ long but often shorter. Hypanthium short and broad, with little, if any, contraction at the apex under the fruiting calyx, the bracteoles minute, linear. Calyx with the tube c. $1.5 \mathrm{~mm}$ long, broadly and somewhat obliquely expanding above the hypanthium, with dense antrorse hairs, the lobes deltoid and with or without long extended tips, from a little to much longer than the tube, not conspicuously unequal, the sinuses narrowly rounded. Standard mostly $7-10 \mathrm{~mm}$ long and 8-12 mm wide, abruptly tapering to a long little-tapered slender claw with a strongly thickened narrow irregular area at its apex. Wings c. 5-8 mm long, much curved, narrowly oblong, the apex shortly and obliquely rounded (the upper part longer), the claw short and strongly curved, the auricle rather small, narrow, rounded and recurved. Keel 6-10 mm long and 2.5-3 mm deep, with the apex obtuse and with a slight twist near the tip, with the upper margin curved downward from the rounded tip, and more sharply upward to the short truncate or deltoid auricles, with distinct central pocket-like folds, the claw short, straight and a little recurved. Ovary 3-4 mm long, elliptic-oblong, curved, densely pubescent, with hairs appressed except along the suture where raised especially near the base, obliquely tapering (and directed a little downward) at the apex and contracted at the base. Ovules numerous. Stipe c. $1 \mathrm{~mm}$ long, broad, glabrous. Style rarther stout, evenly tapered above a narrower basal (c. 1/3) area, curved, more strongly near the base, not thick, and terete, in the lower $1 / 3$, the upper $2 / 3$ stiff pale and laterally flattened with a narrow translucent ridge along the side opposite the beard near the apex, that terminates behind a short slender curved geniculate segment; with a slight but obvious twist, the beard variable but often sparse below and dense in the upper part and on the tip. Fruit (8-)10(-14) $\mathrm{mm}$ long and 5-10 $\mathrm{mm}$ wide, usually very broadly (occasionally narrowly) oblong or even almost spherical, but very variably inflated so that often dorsiventrally compressed, with the suture not much intruded (c. $1 \mathrm{~mm}$ ), obtuse at the base above a short stipe, and at the apex below or even in front of a strongly recurved style c. 3$4 \mathrm{~mm}$ long, becoming raised or erect at maturity, dehiscent at the suture, especially at the ends, with fine antrorse or spreading, often conspicuously tubercle-based, hairs, the texture variable usually depending on inflation and often very softly or stiffly almost papery, the veins usually obscure but sometimes conspicuous at $60^{\circ}-90^{\circ}$, the tissue very deep in the centre and tapering to the ends, not closing the loculus when the fruit is much-inflated.

Widespread in inland areas of Western Australia, South Australia and New South Wales and in the southern part of the Northern Territory and Queensland. Mostly in red sand or loam, occasionally in clay, often in areas with subsoil moisture such as floodplain, especially on open plain and in eucalypt or mulga woodland. Fig. 21. 
SELECTED SPECIMENS (from c. 205 examined): WESTERN AustRALIA: 33 miles [53 km] NW of Leonora, on road to Lawlers, Aplin 2342, 18 Aug 1964 (K, PERTH). NoRTHERN TERRITORY: railway crossing near McDonald yards, McColl, 5 Mar 1981 (NT). South AustraLIA: Warrina, Lothian 4913, 31 July 1968 (AD). QueENSLAND: Betoota, Blake 12166, 17 July 1936 (BRI, NSW). New South WaLes: Nantilla, Richley 1053, 8 Aug 1973 (AD).

\section{S. paucifoliolata J. Thompson, sp. nov.}

Herba prostrata vel ascendens perennis forsan usque ad c. $15 \mathrm{~cm}$ alta. Foliola 3-7 plerumque angusto-lanceolata. Racemi plerumque 5-15 cm longi floribus 7-10 mm longis. Calyx lobis longi-acuminatis tubo longioribus. Vexillum versus basim lineis crassis. Carina obtusa. Stylus complanatus incrassatus cresta translucenti apice inflexo. Fructus 10-15 mm longus c. $4 \mathrm{~mm}$ latus oblongus.

Type: Western Australia: $8 \mathrm{~km} \mathrm{~W}$ of Meekatharra, N.H. Speck 569, 3 Sep 1957; holo NSW; iso CANB, PERTH).

A perennial, perhaps to $\mathrm{c.} 15 \mathrm{~cm}$ high, with prostrate or ascending stems from the top of a taproot. Stems 1-3 mm wide, ribbed or somewhat flattened especially near the nodes, often conspicuously curved-flexuose as if scandent, with sparse hairs, the hairs usually straight, acute at the apex and often at both ends, sometimes dark, somewhat flattened, mostly appressed, $0.5 \mathrm{~mm}$ long or shorter and basifixed or subbasifixed. Leaves mostly 5-7 mm long, occasionally much dwarfed, with 3-7 leaflets above a usually extended petiole, the leaflets mostly narrow-lanceolate and longattenuate, occasionally with the broad and obtuse juvenile leaves persisting, the pubescence appressed, and sparse on or absent from the upper surface, the lateral leaflets usually $10-25 \mathrm{~mm}$ long and $2-3 \mathrm{~mm}$ wide, the terminal much longer, the leaflet-apex long-tapering and acute or acuminate behind a narrow point. Stipules 2$6 \mathrm{~mm}$ long, deltoid, often very narrowly so, with the tip acuminate, green, not forming an abaxial ridge, and with a few hairs on the outer surface. Racemes mostly 5-15 $\mathrm{cm}$ long, with $3-\mathrm{c}$. 16 flowers of even age. Peduncle $0.5-2 \mathrm{~mm}$ wide, with the pulvinus distinct and often dark, with flowers occupying up to $1 / 2$ but usually $1 / 4-1 / 3$ of the peduncle-length, conspicuously ribbed, with a sparse appressed pubescence or, especially in the upper part, denser, dark and more spreading hairs. Bracts ovatelanceolate, 1-2 mm long. Flowers purple, 7-10 mm long, on densely, often dark, pubescent pedicels 1-2 mm long. Hypanthium short and broad, with little if any contraction under the fruiting calyx, the bracteoles minute, linear or lanceolate. Calyx with the tube c. $2 \mathrm{~mm}$ long and rather suddenly and obliquely, but not broadly, expanded above the hypanthium, the pubescence mostly dense, spreading or loosely antrorse, the lobes deltoid, sometimes narrowly so, with long acuminate slender tips, longer than the calyx-tube, not very dissimilar, the sinuses narrow and rounded. Standard 8-10 mm long and as wide, abruptly tapering to a long claw that is tapered but very slender, with two vertical thickened areas, sometimes tending to merge at the base. Wings 7-8 mm long, much curved, narrowly oblong, the apex shortly and rather obliquely rounded (the upper part long), sometimes a little broader, the claw rather short, slender and strongly curved, the auricle relatively large and deltoid and erect or recurved. Keel $8-10 \mathrm{~mm}$ long and 2-3 $\mathrm{mm}$ deep, with the apex obtuse and with a slight twist near the tip, with the upper margin curved slightly downward well behind the apex, the claw long, slender and straight, the auricles long-deltoid and extending backward with pockets near the base. Ovary 3-4 $\mathrm{mm}$ long, narrowly elliptic, and slightly curved, with a dense, very long pubescence loosely appressed towards the base on the sutural side where irregular; obliquely tapered at the ends. Ovules numerous. Stipe c. $1 \mathrm{~mm}$ long, slender, glabrous. Style rather stout, not or very shortly broad-based, laterally flattened, stiff and pale only in the upper $2 / 3$ or more, 
with a very narrow translucent ridge near the apex and reaching around the bend of the inflexed narrow terminal segment, with an obvious twist, a curve that is strongest at the base and a beard that is long and rather sparse except in the upper part and on the tip. Fruit 10-15 cm long and c. $4 \mathrm{~mm}$ wide, oblong, inflated but either side of a variously broadly or narrowly intruded suture often closing the loculus, so that often somewhat dorsiventrally compressed, tapering suddenly at the base above a short stipe and, at the apex, obtuse or shortly acute behind a very small beak bearing the strongly recurved, c. $5 \mathrm{~mm}$ style, becoming raised at maturity, the dehiscence not seen, with long, very fine, spreading, conspicuously tubercle-based hairs, the texture soft but becoming rather stiff, the veins obscure at $60^{\circ}-90^{\circ}$, the tissue deep but irregular, probably closing the loculus or folded within it.

In the western part of Western Australia. In soakage areas, sometimes associated with Acacia. Fig. 21.

This species is named for its few leaflets, a feature not common in the genus. From the Latin paucus, few; foliolatum, leafleted.

Selected specimens (from 15 examined): Western Australia: Carnarvon, Lawson, 1953 (PERTH); Boolardy Station, Humphries, 21 Sep 1950 (PERTH); 30 miles [48 km] S of Sandstone, Gardner 14397, 26 Aug 1963 (PERTH); Mt Magnet, Fitzgerald, Sep 1903 (NSW); Cashmere Downs Homestead, Beard 6497, 9 Sep 1973 (NSW, PERTH).

\section{S. tenuis E. Pritzel}

(Pritzel in L. Diels \& E.G. Pritzel 1904: 270)

TYPe: Western Australia: Murrin Murrin, Austin distr., W.J. George, 1902; holo B, ?extant; E of Laverton, Clarke Geol. Survey 135, 1916; neo (fide A. Lee 1948: 196) PERTH.

A prostrate perennial, rarely reaching $30 \mathrm{~cm}$ high, with numerous stems, often muchbranched below the soil-surface, and a taproot. Stems usually 1-1.5 mm wide, terete or with short ridges below the nodes, the hairs rather dense, usually antrorsely divergent or spreading, most c. $0.5 \mathrm{~mm}$ long, terete to somewhat flattened, acute and basifixed or laterally attached at the base. Leaves c. 2-7 cm long, with 5-9 leaflets above a usually much extended petiole, the leaflets obovate to narrowly, almost linear-, elliptic, the pubescence appressed to spreading widely, variable in density and usually absent from the upper surface, the lateral leaflets mostly 5-10 mm long and 1-2 mm wide, the terminal from a little to very much longer than the upper laterals, the leaflet-apex usually obtusely rounded with a small point but often tapering to a narrow acute tip and occasionally retuse or, perhaps as a juvenile condition, emarginate. Stipules mostly 2-5 mm long, deltoid to almost linear, mostly green, well separated at the back, the pubescence usually absent from the upper surface. Racemes $1-7(-15) \mathrm{cm}$ long, with 1-7 flowers of almost even age. Peduncle c. $0.5 \mathrm{~mm}$ wide, with the pulvinus distinct, pubescent and often dark, with flowers on the top $1-1.5 \mathrm{~cm}$ or subumbellate, ribbed, with hairs rather dense, stiff, and mostly antrorsely divergent or spreading, usually more dense and sometimes dark in the upper part. Bracts ovate-lanceolate, 1-2 mm long. Flowers purple, 7-9 mm long, on pubescent, sometimes dark-pubescent, pedicels c. $3 \mathrm{~mm}$ long. Hypanthium short and very broadtopped, not contracting at the apex under the fruiting calyx, the bracteoles minute, often linear. Calyx with the tube 1.5-2.5 mm long, rather oblique but scarcely expanding above the hypanthium and only gradually above that, with a dense, stiff pubescence, the lobes narrowly deltoid, variably attenuated to, often very long, slender tips, very much, often several times, longer than the tube, the sinuses narrow. Standard usually 9-11 $\mathrm{mm}$ long and as wide or a little wider, abruptly tapering to a long, 
rather slender, tapered claw, with two vertical strongly thickened areas tending to merge above the claw, with a concave area above it. Wings 6-8 mm long, curvedoblong, the apex shortly and obliquely obtuse (the upper part longer), the claw not long, broad-based and tapering, and much curved, the auricle rather distinct, raised, narrow, rounded and recurved. Keel 7-10 mm long and 3-4 mm deep, with the apex obtuse, somewhat swollen and with a distinct, sharp, lateral twist, with the upper margin very slightly upcurved behind the tip and very slightly downcurved in front of the deltoid or rounded auricles often lying close to the rather short, straight, rather broad and scarcely tapered claw, with the pockets irregular, often obscure or even absent. Ovary c. $4 \mathrm{~mm}$ long, elliptic-oblong, curved, densely pubescent with hairs appressed except at the base of the sutural side where irregular, obliquely tapering and directed a little downward at the apex, and obliquely contracting at the base. Ovules numerous. Stipe c. $0.5 \mathrm{~mm}$ long, rather slender, glabrous or with a few hairs. Style with the base very shortly broad and tapered, then untapered, curved and unthickened for c. 1/3 its length, the upper c. 2/3 pale, stiffened, slightly twisted and laterally flattened and gradually tapering and curving to an almost truncate narrow apex where a trace of translucent rim is usually visible at the junction of the small, geniculate, narrow, curved, terminal segment, the beard long, usually sparse or absent below and more dense in the upper part and on the tip. Fruit mostly $10-15 \mathrm{~mm}$ long and 4-5 mm wide, elliptic to oblong, inflated either side of a broadly or narrowly intruded suture so that sometimes dorsiventrally compressed, tapering suddenly at the base to a short stipe and, at the apex, tapering to the c. $4 \mathrm{~mm}$ style or rounded below a raised style-base, erect at maturity, the dehiscence not seen, with long, very fine, very minutely tubercle-based antrorse hairs, the texture thinly leathery, i.e. soft but becoming more stiff, the veins fine, at c. $60^{\circ}$, the tissue short or rather deep, sealing the loculus and folded within it.

Widespread in inland parts of Western Australia and western South Australia and in the south-western part of the Northern Territory. In red sandy loam or on stony flats and rocky places, often associated with ranges; often growing with grasses or Acacia. Fig. 21.

Selected specimens (from c. 100 examined): Western Australia: Windidda Spring, near SE end of Lake Carnegie, Chinnock 870, 7 Sep 1973 (AD, PERTH); $125 \mathrm{~km} \mathrm{E} \mathrm{of} \mathrm{Norseman,} \mathrm{Woolcock} \mathcal{E}$ Woolcock 2353, 6 Oct 1985 (CBG). NORTHERN TERRITORY: foot of Ayers Rock, near climb, Wittman ANU4065, 28 Aug 1964 (CANB). South Australia: E end of Champ de Mars, Tomkinson Ranges, c. $2.5 \mathrm{~km} \mathrm{~W}$ of Pipalyatjara-Wingellina road, Barker 8251, 4 Sep 1978 (AD, BRI, CANB); Everard Range, c. 6.5 km NE of Carmeena Well, Eichler 17510, 15 Sep 1963 (AD, NSW, NT).

\section{S. reticulata J. Black}

\section{(J.M. Black 1924b: 320)}

TYPe: SOUth Australia: sand, River Murray, herb. Tate, 8 Sep 1883; lecto (fide Lee 1948: 198) AD.

S. oroboides subsp. reticulata (J. Black) A. Lee (A.T. Lee 1948: 198). TYPE: as for the species.

A prostrate perennial to $\mathrm{c.} 15 \mathrm{~cm}$ high, with many slender stems from a taproot or much-branched stout stock, often with the stem-bases below the soil-surface. Stems c. $1 \mathrm{~mm}$ wide, terete or with strong ridges from the horizontal nodes, the hairs usually rather dense, $0.5-1 \mathrm{~mm}$ long, mostly antrorsely divergent but occasionally spreading, sometimes somewhat crisped, terete or somewhat flattened, acute, and basifixed or laterally attached at the base. Leaves 1-7 cm long, with 5-15 leaflets above a usually long-extended petiole, the leaflets obovate, elliptic or often very narrowly linear- 
lanceolate, the pubescence of long loosely appressed hairs on both surfaces or the upper surface glabrous, the lateral leaflets 3-15 $\mathrm{mm}$ long and usually 1-3 $\mathrm{mm}$ wide, the terminal variable in relation to the, sometimes much shorter, upper laterals, the leaflet-apex from narrowly acute (in narrow leaves) and with a small point, to obtuse or even emarginate with a broad central point. Stipules $2-7 \mathrm{~mm}$ long, broad-based and broad-deltoid to long-deltoid-acuminate, green, or scarious at the extended base, well separated or adjacent, with the formation of an abaxial collar-like ridge only near the base of the stems, and the pubescence scattered with few hairs on the upper surface. Racemes to more than $20 \mathrm{~cm}$ long, with 3-7 flowers of almost even age. Peduncle c. $0.5 \mathrm{~mm}$ wide, with the pulvinus distinct, often dark, with flowers subumbellate or in the top $1 / 6$ or less, terete or obscurely ribbed with appressed, loosely antrorse, rarely spreading, hairs dense and often dark in the upper part. Bracts ovate, often c. $2 \mathrm{~mm}$ long. Flowers purple, 5-10 $\mathrm{mm}$ long, on densely, often dark, pubescent pedicels $2-5 \mathrm{~mm}$ long. Hypanthium short and usually rather broad, not or somewhat contracting under the fruiting calyx, and with minute bracteoles. Caly $x$ with the tube c. $2 \mathrm{~mm}$ long, rather obliquely expanding somewhat above the top of the hypanthium, with a rather dense stiff pubescence, the lobes deltoid-acuminate, often with apices extended, from almost equal to, to longer than, the tube, the sinuses narrow. Standard 8-10 mm long and 7-11 mm wide, abruptly tapering or contracting to a long-tapered claw, slender at the base, with two rather small vertical calli and a concave area above them. Wings 5-8 $\mathrm{mm}$ long, curved-obovate-oblong, the apex shortly and obliquely (the upper part longer) obtuse, the claw rather long, curved, tapered and slender, the auricle large and rounded and tending to recurve. Keel 6-8 $\mathrm{mm}$ long and 2-3 mm deep, with the apex rather variably acute, i.e. narrow, and a little swollen below the tip, scarcely, if at all, twisted, with the upper margin upcurved behind the tip and then shortly downcurved, ascending gradually to the rather deep backwardly directed rounded-deltoid auricles, with pouches near the claw, the claw straight, broad above and obviously tapering. Ovary c. $4 \mathrm{~mm}$ long, oblong-elliptic, curved, densely appressed-pubescent, tapering obliquely or rather evenly at the apex and more abruptly and obliquely at the base. Ovules numerous. Stipe c. $0.5 \mathrm{~mm}$ long, rather slender, virtually glabrous. Style (Fig. 6) rather slender, with the base and c. 1/ 3 the style-length tapering scarcely if at all, flattened, curved and unthickened, the upper $2 / 3$ a little expanded but still slender, much stiffened and pale and laterally flattened, scarcely curved, not twisted and, though the thickened area tapers towards the apex, there is a ridge of translucent tissue extending from the side opposite the beard and increasing in depth so as often to counteract the taper, the style terminating in a short, usually very slender, geniculate segment beyond a tip that appears truncate from the translucent margin that is broadest at, and narrows beyond, the tip, the beard usually sparse but variable in extent, from the whole length to absent, but hairs more frequent near and on the apical part. Fruit (Fig. 7) 13-22 mm long and 4$5 \mathrm{~mm}$ wide, narrowly obovoid, a little curved, inflated with the suture variably indented, usually not, or only slightly dorsiventrally compressed, suddenly tapering at the base to a very short stipe and shortly tapered or rounded at the apex behind or below a short raised beak bearing the 4-5 mm style, erect at maturity with some partial dehiscence along the upper suture, with fine, but not very long, loosely appressed hairs, the texture stiff, the veins rather fine but somewhat raised at $60^{\circ}$, the tissue ragged and variable, not always closing the loculus.

Along the Murray River valley, widespread especially on the Western Slopes and Tablelands of New South Wales and reaching southern Queensland. On alluvial flats, usually of light red soil, in grassland or in open forest. Fig. 21.

SELECTED SPECIMENS (from c. 160 examined): South Australia: Rotten Lake, Calperum Station East, Renmark-Wentworth road, Hall 119, 22 Sep 1984 (AD). QuEENSLAND: c. 30 km ENE of Texas, on road to Stanthorpe, Henderson 2541, 5 Oct 1977 (BRI, NSW). New South WALES: 
Walcha-Uralla road, Armstrong 517, 21 Sep 1973 (NSW); near Laheys Creek, between Moonbi \& Bendemeer, Goode 133, 13 Nov 1954 (BM, NSW). Victoria: Mail Route on River Road from Merbein, $5 \mathrm{~km} \mathrm{~W}$ of Neds Corner Station Homestead turnoff, Browne 165, 23 Sep 1983 (MEL).

\section{S. behriana F. Muell. ex J. Black}

(J.M. Black 1927: 379)

TYPE: SOUTH Australia: in planitie graminosa ad Adelaide, F. Mueller; holo K; iso MEL.

S. oroboides var. hirsuta J. Black (J.M. Black 1924a: 320); S. oroboides subsp. hirsuta (J. Black) A. Lee (A.T. Lee 1948: 200). TYPE: SouTH AustraliA: Brighton, J.M. Black, 18 Sep 1909; lecto (fide Lee 1948: 200) AD; iso NSW.

A prostrate or low-growing perennial, perhaps reaching $15 \mathrm{~cm}$ high, with a stout stock and many slender stems often extending under the soil-surface and branching there. Stems mostly $1 \mathrm{~mm}$ wide or less, terete but usually with a strong ridge below the node, the hairs usually rather dense, spreading, irregularly directed or antrorsely divergent, of variable length but often c. $0.75 \mathrm{~mm}$, terete to somewhat flattened, acute and basifixed, often with the base swollen, or laterally attached at the base. Leaves usually 3-5 cm long, with 9-13 leaflets above a long petiole, the leaflets usually narrowly elliptic, occasionally obovate, the pubescence appressed to spreading widely, usually sparse on, or even absent from, the upper surface, the lateral leaflets mostly 5-10 mm long and 1-3 mm wide, the terminal usually obviously longer than the upper laterals, the leaflet-apex usually acute, occasionally obtuse and often broadly emarginate with a central point. Stipules $2-5 \mathrm{~mm}$ long, ovate to very narrowly deltoid, variably long-attenuate but broad-based where often pale, otherwise green, often very close at the back with the abaxial ridge usually very distinct and collarlike, and with the sparse pubescence absent from the inner surface. Racemes mostly 5-15 $\mathrm{cm}$ long, with 2-7 flowers of even age. Peduncle from less than 1 to $1.5 \mathrm{~mm}$ wide, with the pulvinus distinct, pubescent and often dark, with flowers clustered near the apex and usually subumbellate, ribbed, pubescent with rather coarse, often irregular, antrorsely directed to spreading hairs, often dense and often dark and usually very dense in the upper part. Bracts ovate, often $2 \mathrm{~mm}$ long. Flowers purple, $7(-10) \mathrm{mm}$ long, on densely, and dark-, pubescent pedicels 1-3 mm long. Hypanthium short and broad, with little contraction at the apex under the fruiting calyx, the bracteoles small and usually linear. Calyx with the tube 2-2.5 mm long, somewhat expanded above the top of the hypanthium, with a dense and usually dark loosely appressed or somewhat divergent pubescence, the lobes deltoid with variably attenuate tips, occasionally shorter than but often somewhat longer than the tube, the sinuses often narrowly rounded but variable. Standard 7-8 $\mathrm{mm}$ long and 9-12 $\mathrm{mm}$ wide, contracting to a rather long, slender tapered claw with a bipartite very strongly thickened area at the apex and with a concave area above this. Wings 7-8 $\mathrm{mm}$ long, curvedoblong, the apex shortly and obliquely rounded, sometimes a little expanded (the upper edge longer), the claw short, slender, tapering and much curved, the auricle small, narrow, rounded or deltoid and recurved, and with a distinct fold or thickening at the base. Keel mostly 7-9 mm long and 2.5-3 mm deep, with the apex obtuse, sometimes narrowly, somewhat inflated below, slightly or scarcely twisted at the tip, with the upper margin curving downward behind the broadly curving tip and upward in front of the large deltoid backwardly directed auricles, and with pockets at the base, the claw of moderate length, straight and slightly tapered. Ovary c. $4 \mathrm{~mm}$ long, elliptic-oblong, curved, densely pubescent, the hairs appressed or tending to be looser along the suture, with a few twisted at the base, obliquely tapered and a little 
downwardly directed at the apex and contracting obliquely at the base. Ovules numerous. Stipe c. $0.5 \mathrm{~mm}$ long, rather slender, pubescent. Style rather slender, shortly tapered at the extreme base and unthickened, curved and unflattened for c. 1/3 its length, the upper c. 2/3 expanding a little and then gradually tapering, only very slightly curved, strongly thickened, pale and laterally flattened with a translucent ridge along the margin opposite the beard and around the bend of the slender, inflexed or geniculate, curved slender tip, with a very slight twist in the thickened region, the beard along the whole length but sparse except in the upper part and on the tip where long, fine and spreading. Fruit $10-18 \mathrm{~mm}$ long and 4-7 mm wide, oblong or somewhat broader at the apex, inflated either side of a very broadly or narrowly intruded suture, often compressed, obtuse at the base above a c. $1 \mathrm{~mm}$ stipe and at the apex below a short, often erect, beak below a 3-4 mm style, often twisted at the base, becoming raised or even erect at maturity, tardily dehiscent at the suture, with a fine rather short antrorse, or occasionally spreading, pubescence, the texture stiffly leathery, the surface smooth or with some raised reticulation, the veins delicate or narrowly raised at $\mathrm{c} .75^{\circ}$, the tissue ragged, short, closing the loculus.

Usually in light, occasionally rather heavy, soils, in moist grassland, especially in woodland and forest clearings. In south-eastern South Australia, widespread in Victoria and on the tablelands of eastern New South Wales. Fig. 21.

Selected specimens (from c. 175 examined): South Australia: Belair, Koch 904, Sep 1902 (PERTH); Freeling, Kraehenbuehl 1759, 17 Sep 1966 (AD). New SoutH WaLes: Gudgenby Crossing, Burbidge 6768, 23 Nov 1960 (CANB); Little Thredbo River flats, near Thredbo River, Thompson 4134, 30 Nov 1981 (NSW). Victoria: Lara, Gates 986, 19 Sep 1926 (MEL).

\section{S. campestris J. Black}

(J.M. Black 1924b: 220)

TYPE: South Australia: Hughes (Nullarbor Plain), E.H. Ising, 6 Sep 1920; holo AD; iso AD, K, NSW.

An erect or ascending perennial to c. $60 \mathrm{~cm}$ high, with many stems from a taproot, their bases sometimes below the soil-surface. Stems mostly $1.5-2.5 \mathrm{~mm}$ wide, ridged from the nodes, the hairs c. $0.5 \mathrm{~mm}$ long, variable in density, usually straight and appressed, occasionally irregular and spreading, terete or, often only a little, flattened, narrow and tapering to a slender apex and basifixed or subbasifixed. Leaves (1)5-8(-10) $\mathrm{mm}$ long, with 9-11 leaflets above an extended petiole, the leaflets usually very narrowly lanceolate-elliptic but occasionally expanded near the apex, usually with scattered appressed, occasionally spreading, hairs on both surfaces but fewer on the upper, the lateral leaflets mostly 5-20 mm long and 1-2(-4) $\mathrm{mm}$ wide, the terminal usually conspicuously longer than the upper laterals, the leaflet-apex usually long-tapering to a small recurved point but often obtuse or even broadly emarginate or 3-lobed. Stipules 3-10 mm long, narrowly deltoid and long-tapering, green, widely spaced, not forming an abaxial ridge and pubescent only on the outer surface. $R a$ cemes 10-25 cm long, with 5-10 flowers of even age. Peduncle $0.5-1.5(-2) \mathrm{mm}$ wide, with the pulvinus conspicuous, often dark and/or pubescent, with flowers in the upper few centimetres, usually $1 / 3$ or less of the length, ribbed, the hairs antrorse, often rather sparse but dense and more divergent, and often dark, in the upper part. Bracts ovate-lanceolate, c. $2 \mathrm{~mm}$ long. Flowers pink or purple, $8-10 \mathrm{~mm}$ long, on densely, often dark, pubescent pedicels $1-3 \mathrm{~mm}$ long. Hypanthium very short and broad, not contracting at the apex under the fruiting calyx, the bracteoles small, often broad. Calyx with the tube c. $2.5 \mathrm{~mm}$ long, expanding obliquely and rather broadly above the top of the hypanthium, with a rather coarse divergent to spreading, often 
dark, pubescence, the lobes deltoid, sometimes acuminate, shorter than the tube and, not very dissimilar, the sinuses mostly rather broad and rounded. Standard c. 10-12 $\mathrm{mm}$ long and 3-10 mm wide, abruptly or gradually tapering to a long-tapered claw, with two round or amorphous thickenings at the base. Wings 6-10 $\mathrm{mm}$ long, slightly curved, ovoid-oblong, with the apex broad and very shortly and obliquely (the upper edge longer) obtuse, the claw long, slender and somewhat curved, the auricle large, erect, rounded-deltoid and folded. Keel 7-9 mm long and c. $3 \mathrm{~mm}$ deep, with the apex obtuse, often rather narrowly so, not or scarcely expanded below and a little, sometimes not, twisted, with the upper margin widely and shallowly upcurved near the tip and curved downward, sometimes strongly, in front of the deep rounded deltoid auricles, with large pockets near the auricle-bases, the claw straight long slender and scarcely tapering. Ovary c. $4 \mathrm{~mm}$ long, elliptic-oblong, curved, densely pubescent, obliquely tapering and a little downwardly directed at the apex and obliquely and more shortly tapering at the base. Ovules numerous. Stipe c. $0.5 \mathrm{~mm}$ long, broad, glabrous. Style rather stout, broadest at the base and tapering somewhat for $1 / 3$ its length, this lower part unthickened and curved, above this a little wider, pale and stiff, laterally flattened, somewhat less curved, tapering and distinctly twisted, the apex suddenly tapering to a very slender section that is inflexed to a varying degree and curved, often so as to appear reflexed, the junction of the slender section often marked by a minute translucent flange, the beard along the whole length but often sparse in the middle and dense above, especially on the slender tip. Fruit c. 10-20 mm long and 4-5 $\mathrm{mm}$ wide, oblong or a little wider at the apex, curved, sometimes somewhat dorsiventrally compressed, inflated with a deep suture-intrusion, tapering rather suddenly at the base above minute stipe and rounded at the apex below, or even in front of, a short erect beak bearing a 5-6 mm recurved style, becoming erect at maturity, dehiscent both along the suture and at the back, with a rather long, fine, spreading, minutely tubercle-based pubescence, the texture stiff, the veins usually raised, at $c .45^{\circ}$, the tissue deep and folded in the closed loculus.

In south-western South Australia and south-eastern Western Australia. On open, sandy to clay, red limestone plain, treeless or with sparse woodland. Fig. 21.

Selected SPECIMEns (from c. 65 examined): WeStern Australia: $110 \mathrm{~km}$ S of Rawlinna, Wilson 7681, 3 Sep 1968 (K, PERTH); SE of Forrest, Aplin 1649, 31 Aug 1962 (AD, MEL, PERTH). SouTH Australia: Aerodrome, Koonalda Station, Symon 4599, 17 Feb 1967 (AD, CANB, K, NSW); Cook, Nullarbor Plain, Symon 12745, 29 Aug 1980 (AD, CANB, NSW); Ooldea Sand Dunes, S of the road to Tarcoola, Donner 7530, 3 Aug 1980 (AD).

61. S. vestita J. Thompson, sp. nov.

Herba erecta vel ascendens perennis usque ad c. $25 \mathrm{~cm}$ alta. Foliola c. 7 anguste lanceolato-elliptica. Racemi 5-20 cm longi floribus c. $10 \mathrm{~mm}$ longis. Calyx lobis tubo sublcngioribus. Vexillum versus basim callis duobus grandibus. Carina anguste obtusa. Stylus complanatus incrassatus apice geniculato ad juncturam minute translucento.

TYPe: South Australia: $18 \mathrm{~km}$ W of Coober Pedy, T.S. Henshall 3079, 21 May 1980; holo NSW; iso NT.

An erect or ascending perennial to c. $25 \mathrm{~cm}$ high, with a number of stems, often branching near the base and often below the soil-surface, appearing to arise in clusters from a stout stock. Stems most $1.5-2.5 \mathrm{~mm}$ wide, strongly ridged or angled from the nodes, the hairs $0.75-1.5 \mathrm{~mm}$ long, very fine with the apex and often the base narrower, usually dense, straight and appressed or divergent, terete or somewhat flattened and basifixed, subbasifixed or occasionally, laterally attached near the base. 
Leaves c. 3-10 cm long, with c. 7 leaflets above a well-extended petiole, the leaflets narrowly lanceolate-elliptic, tapering at both ends, with an appressed to divergent pubescence on both surfaces, the lateral leaflets mostly $10-25 \mathrm{~mm}$ long and 1-3 mm wide, the terminal often very much longer than the upper laterals, the leaflet-apex acute and pointed. Stipules often c. $5 \mathrm{~mm}$ long, very narrowly acuminate-deltoid, green or pale near the base, widely separated at the back, not forming an abaxial ridge and pubescent on both surfaces, more densely near the margins. Racemes 5-20 $\mathrm{cm}$ long, with 2-7 flowers of almost even age. Peduncle 1-1.5 mm wide, with the pulvinus conspicuous, sometimes dark, with flowers in the upper $1-3 \mathrm{~cm}$, i.e. $1 / 6$ or less of its length, ribbed, especially in the upper part, the hairs occasionally sparse, often rather dense, appressed. Bracts acuminate, deltoid, c. $2 \mathrm{~mm}$ long. Flowers purple, c. $10 \mathrm{~mm}$ long, on pubescent pedicels 1-3 mm long. Hypanthium short and broad, with minute linear bracteoles. Calyx with the tube $2-2.5 \mathrm{~mm}$ long, obliquely, but only a little, expanded above the top of the hypanthium, with an appressed or somewhat divergent dense, not dark, pubescence, the lobes very narrowly deltoid, acuminate and narrow at their apices, a little longer than the tube, not very dissimilar, the sinuses rather broad, acute or rounded at the base. Standard c. 10-12 mm long and 9$12 \mathrm{~mm}$ wide, gradually or abruptly tapering to a long tapered claw, with two large calli at the base. Wings 8-10 $\mathrm{mm}$ long, narrowly obovate, the apex rather evenly rounded or a little longer above, the claw not long, tapered and much curved, the auricle large and rounded, erect or directed backward, and often folded. Keel 10-11 $\mathrm{mm}$ long and c. $4 \mathrm{~mm}$ deep, with the apex rather narrowly obtuse, somewhat expanded below and often a little twisted near the tip, with the upper margin with a shallow upward curve behind the tip extending almost to the auricles where there is a slight downcurve in front of the rather deep truncate or deltoid auricles, the pocket below the auricle distinct, the claw rather short, straight, broad and scarcely tapering. Ovary c. $5 \mathrm{~mm}$ long, narrowly oblong-elliptic, densely pubescent, obliquely tapering at the apex and with an oblique abrupt taper at the base. Ovules numerous. Stipe c. 0.5 $\mathrm{mm}$ long, narrow, glabrous. Style rather stout, c. $5 \mathrm{~mm}$ long, evenly tapered and shallowly curved to the apex, with a geniculate slender curved terminal segment, not thickened in the lower c. 1/3 but laterally flattened, stiff, pale and slightly twisted in the upper part, with a trace of translucent tissue at the junction of the geniculate segment, the beard along the whole length but sparse in the central area and rather dense in the upper and on the tip. Fruit not seen.

In a small area of central northern South Australia. On open stony plains, with shrubs and grasses. Fig. 22.

This species is named for its long and conspicuous hairs. From the Latin vestitus, clothed.

SPECimens eXAmined: South Australia: Mt Evelyn Station, $12 \mathrm{~km}$ E of Copper Hills Homestead, Henshall 3155, 23 May 1980 (NSW, NT); c. $25 \mathrm{~km} \mathrm{~N}$ of Box Hole Creek crossing, Stuart Highway, Barker 3543, 16 Sep 1978 (AD).

\section{S. sericea (A. Lee) H. Eichler}

(Eichler in J. Black 1965: 193)

BAsIONYM: S. oroboides subsp. sericea A. Lee (A.T. Lee 1948: 201).

TYPe: New South WALES: Cowra, J.B. Cleland NSW 527, 10 Sep 1913; holo NSW; iso AD, NSW.

A prostrate or low-growing perennial to $\mathrm{c} .10 \mathrm{~cm}$ high, with many slender stems from a stout gnarled rootstock, the stem-bases often below the soil-surface. Stems mostly 1$2 \mathrm{~mm}$ wide, often with angles or ridges gradually expanding below the nodes, the 
hairs rather dense, $0.5-1 \mathrm{~mm}$ or more in length, often dark, slender, pointed, often at both ends, narrow, flattened or terete, asymmetrically medifixed, often on a minute extension, and appressed or with one or both ends variously raised and occasionally irregular. Leaves mostly 2-7 cm long, with 5-13 leaflets above an often much extended petiole, the leaflets usually narrowly elliptic, occasionally broader near the apex, with a dense pubescence of closely or loosely appressed, occasionally spreading, hairs, on both surfaces but often sparse on the upper, the lateral leaflets mostly 5-15 mm long and 1-3 mm wide, the terminal usually much longer than the upper laterals, the leaflet-apex usually long-tapering to an often recurved small point, sometimes more rounded, or even emarginate, with a central point. Stipules mostly 3-7 mm long, ovate-deltoid to long-deltoid, green or with the base scarious, often adjacent and usually but not invariably forming an abaxial ridge or collar, and pubescent but only on the outer surface. Racemes 5-c. $15 \mathrm{~cm}$ long, with 2-c. 8 flowers of virtually even age. Peduncle from less than 0.5 to $1.5 \mathrm{~mm}$ in length, with the pulvinus conspicuous and usually dark, with flowers sometimes spaced so as to occupy $1 / 2$ the length, usually spaced and occupying the top 1-2 cm, occasionally subumbellate, ribbed, the hairs usually subbasifixed, loosely appressed and rather dense, more dense, often spreading, and usually dark, in the upper part. Bracts lanceolate, 1-3 mm long. Flowers purple, 7-11 mm long, on densely, and dark, pubescent pedicels 1-3 mm long. Hypanthium short and broad, not much contracted at the top under the fruiting calyx, with short broad bracteoles. Calyx with the tube 1.5-2 mm long, expanding, but often only gradually, above the top of the hypanthium, with dense, often very dark, antrorse hairs, the lobes mostly deltoid, often with narrow acuminate tips, about equal to the tube or sometimes a little shorter or, more frequently, longer, not conspicuously unequal, the sinuses usually narrow. Standard 8-14 $\mathrm{mm}$ long and 8-14 mm wide, abruptly tapering or almost truncate above a slender long claw, with two angled thickenings below a concave area. Wings 6-10 mm long, somewhat curved, somewhat obovate, the apex shortly and obliquely obtuse, the upper edge longer, the claw short, rather broad and tapering, and curved, the auricle rather narrow, erect, recurved, rounded and folded. Keel 7-10 mm long and c. $4 \mathrm{~mm}$ deep, with the apex obtuse, often rather narrowly, with conspicuous swellings behind the tip and a very slight lateral twist, with the upper margin very slightly raised behind the tip and then with a very slight downward curve to the rather deep deltoid backwardly directed auricles, and with distinct pockets at the auricle bases, the claw straight long and slender with only slight taper. Ovary 4-6 mm long, elliptic-oblong, curved, densely pubescent, obliquely tapering and a little downwardly directed at the apex, and obliquely and abruptly tapering or contracting at the base. Ovules numerous. Stipe c. $0.5 \mathrm{~mm}$ long, narrow, glabrous. Style slender, the base sometimes somewhat broader and tapering, the lower c. 1/3 unthickened and curved, above this the top 2/3 laterally flattened stiff and pale, scarcely or slightly twisted, a little or scarcely broader at the base and evenly tapering to a slender sometimes almost truncate apex with a slender lateral geniculate segment, sometimes with a minute translucent flange on the bend, the beard usually confined to the base and the apex, including the lateral segment. Fruit usually 10-17 $\mathrm{mm}$ long and 6-7 mm wide, obovate to narrowly obovate, curved, somewhat dorsiventrally compressed, inflated with the suture deeply intruded, tapering rather suddenly or obtuse at the base above a minute stipe, and at the apex obtuse with a small variably upwardly directed beak behind a $6-7 \mathrm{~mm}$ recurved style, becoming raised or erect at maturity, dehiscent along the suture and the other side, with rather short, fine, spreading hairs on minute tubercles, the texture stiff, the veins fine and at $60^{\circ}$, or occasionally raised on the sutural side, the tissue ragged and folded in the closed loculus.

In south-eastern South Australia, northern Victoria and especially the south-eastern half of New South Wales. In grassland and open eucalypt woodland, sometimes with 
Callitris, and on sandhills. Fig. 22.

SeleCted SPECIMENS (from c. 130 examined): South Australia: near Tepko, Cleland, 28 Sep 1968 (AD). New SOUTH WALES: c. midway between Gulgong \& Ulan, Medd 160950, 5 Sep 1983 (NSW); Wingello, Boorman NSW 692, 29 Dec 1913 (NSW); Mawson, Canberra, Taylor 2355, 17 Oct 1983 (AD, CBG, MEL). VictoriA: Nathalia, Beauglehole 39528, 14 Sep 1960 (MEL).

\section{S. phacoides Benth.}

(Bentham in T.L. Mitchell 1848: 363)

TYPE: QueENSLAND: bed of river 15 miles [c. $24 \mathrm{~km}$ ] SW of Camp 29 [prob. 49], T.L. Mitchell 506 bis, 1 Sep 1846; holo K.

S. phacoides var. parviflora Benth. (G. Bentham 1864: 218). TYPE: New SOUTH Wales: between the Darling and Lachlan Rivers, Burkitt; lecto (fide Lee 1948: 174) MEL; ?iso MEL.

S. phacoides var. argyrophylla J. Black (J.M. Black 1924a: 322). TYPE: SOUTH Australia: River Stevenson, herb. Tate, 2 Aug 1894; lecto (fide Lee 1948: 174) AD; iso NSW.

S. uniflora J. Black (J.M. Black 1933: 152). TYPE: NORTHERn TERRITORY: Horseshoe Bend, Finke R., E.H. Ising, Aug 1931; holo AD; iso AD, K.

S. phacoides var. oocarpa J. Black (J.M. Black 1935: 357). TYPE: NORTHERN TERRITORY: Mt Hay, J.B. Cleland, 8 Aug 1932; lecto (fide Lee 1948: 74) AD; iso AD.

A prostrate or ascending perennial (or ephemeral), rarely reaching more than c. 30 $\mathrm{cm}$, with a long slender taproot, usually bearing numerous stems that often branch below ground. Stems often 1.5-2 mm wide, occasionally 3-4 mm, terete or somewhat angled below the nodes, variably, often densely, pubescent, the hairs of variable length but often 1-1.5 mm long, usually very slender and long-tapering at one or both ends, appressed or with one or both ends raised and sometimes irregular, flat or sometimes terete and medifixed, often very asymmetrically. Leaves variable in length but mostly 5-10 mm long, with 5-13 (often 7) leaflets above a variably extended petiole, the leaflets in general elliptic but from long-tapering at each end to shortly so and from broad to very narrow, densely or sparsely pubescent, the hairs usually appressed, sometimes loosely so, or even spreading, on both surfaces but sometimes more spaced on the upper, the lateral leaflets from less than $5-30 \mathrm{~mm}$ long and 1-5 $\mathrm{mm}$ wide, the terminal mostly conspicuously longer than the somewhat shorter upper laterals, the leaflet-apex variable, from long-tapering to broad and emarginate and occasionally with a short stiff point. Stipules from minute to c. $5 \mathrm{~mm}$ long, in general deltoid or linear-lanceolate, with a long narrow tip, variably extended at the back, green, not forming an abaxial ridge, and with hairs usually sparse and mostly on the outer surface. Racemes 3-20 cm long, with (1-)3-4(-10) flowers of almost even age. Peduncle $0.5-2(-3) \mathrm{mm}$ wide, with the pulvinus usually conspicuous and often dark, with flowers usually occupying only the top 1-2 cm, smooth or slightly striate, the hairs mostly appressed, some basifixed. Bracts lanceolate, c. $2 \mathrm{~mm}$ long. Flowers usually pale to dark reddish purple, mostly 10-15 mm long, on densely, sometimes dark, pubescent pedicels $1.5 \mathrm{~mm}$ long. Hypanthium (Fig. 2) often short and broad, or with an elongate base, somewhat contracted at the apex under the fruiting calyx, the bracteoles narrow and distinct. Calyx (Fig. 2 ) with the tube (1.5-)2-2.5 mm long, not abruptly expanding above the hypanthium, sometimes very gradually so, densely pubescent, the lobes deltoid, usually much longer than the tube and characteristically straight-sided, often long tapering at their apices, the upper scarcely shorter and broader, the sinuses narrow. Standard usually 7-14 $\mathrm{mm}$ long and approximately as 
wide or narrower, tapering to a very short tapered claw, with two small thickenings near the base. Wings 7-9 mm long, oblong to broadly obovoid, curved, the apex very shortly obtuse, the claw rather long, strongly curved and tapering, the auricle variable but mostly short, rounded, recurved and somewhat thickened in the centre or folded. Keel (Fig. 5) mostly 10-15 mm long and c. $5 \mathrm{~mm}$ deep, with the apex obtuse and rounded, with the upper margin raised at the tip then curving slightly downward and slightly upward to the acute deltoid and directed backward auricles, and with the large pockets high and near the auricles, the claw short straight and somewhat tapered. Ovary 5-6 mm long, elliptic and obliquely curved, with a dense long pubescence, mostly appressed but somewhat raised along the suture especially near the base, tapering obliquely and gradually to the style-base and obliquely and more suddenly to the base. Ovules numerous. Stipe c. $0.5 \mathrm{~mm}$ long, broad and partially glabrous. Style gradually tapering from a rather broad base to a slender, usually straight, tip, not twisted, evenly curved, unthickened but laterally compressed, bearded for the whole length but often sparsely at the extreme base. Fruit very variable, often 15-35 mm long and 4-5(-10) mm wide, mostly oblong-elliptic, sometimes curved, inflated, often very strongly, each side of a well-intruded suture, usually somewhat dorsiventrally compressed, at the base rounded above a minute stipe, at the apex usually rounded below and sometimes in front of a very short straight or upturned beak from which the recurved, c. $5 \mathrm{~mm}$, style has often been shed, pendulous to erect at maturity, tardily dehiscing along the suture, with long fine spreading or appressed hairs, the texture very stiff or, in more inflated fruits, softly leathery, the surface variably, often conspicuously, covered with minute tubercles, the veins obscure, at $45^{\circ}-60^{\circ}$, the tissue deep and closing the loculus, often folded inside it.

Common in the southern part of the Northern Territory and much of inland South Australia and western New South Wales, scattered in southern Queensland and along the Murray River valley in Victoria, and rare in Western Australia. In a variety of soils, usually, but not invariably, light, and especially associated with inland sanddunes (coastal on Curtis Island, Queensland), but also in sandy and stony soils, occasionally in creekbeds or in rocky (sandstone, granite or limestone) places. Fig. 22.

SELECTED SPECIMENS (from c. 600 examined): WESTERN AustRALJA: 6 miles $[9.5 \mathrm{~km}] \mathrm{W}$ of W.A.-N.T. border in lat. $23^{\circ} 10^{\prime} \mathrm{S}$, George 8933, 6 July 1967 (CANB, NT, PERTH). NORTHERN TERRITORY: N side of Mt Liebig, Corrick 10326, 7 July 1988 (CBG, MEL, NSW); South Australia: Dakota Bore, $75 \mathrm{~km}$ E of Mt Dare Homestead, Badman 1822, 24 Aug 1985 (AD, NT). QueEnsland: Curtis Island, $\mathrm{N}$ of Southend, towards Connor Bluff, Blake 22560, 28 Mar (BRI). NEw South WaLes: Brewarrina Golf Course, Thompson 1883, 29 Aug 1973 (NSW). Victoria: $6 \mathrm{~km}$ W of Barmah in State Forest, Muir 6110, 2 Oct 1978 (MEL).

\section{Group 11}

\section{Style-tip geniculate}

2 Calyx-lobes broad; keel not greenish yellow 64. S. disjuncta

2* Calyx-lobes narrow; keel greenish yellow 65. S. flavicarinata

1* Style-tip incurved, inflexed or coiled

3 Stem hairs medifixed at least in part; keel-tip not modified

4 Flowers fewer than 10, on slender peduncles; calyx-lobes very long $\ldots$ 66. S. oligophylla

$4^{*}$ Flowers often 30 or more, on stout peduncles; calyx-lobes short $\quad \ldots \quad 72$. S. tephrotricha

$3^{*}$ Stem hairs basifixed; keel-tip modified

5 Keel with a boss or pouch each side of the tip 
6 Stems densely pubescent; style-tip incurled with lateral extensions and a dorsal ridge

70. S. canescens

$6^{*}$ Stems usually sparsely pubescent; style-tip straight and tapering

71. S. incei

$5^{*}$ Keel without a boss or pouch each side of the tip

7 Keel-tip with a flange of undulating tissue; style-tip laterally expanded

8 Fruit longer than wide and with long, fine, spreading hairs

9 Stipules broad; keel-flange narrow

67. S. burkei

9* Stipules narrow; keel-flange broad

68. S. rostrata

$8^{*}$ Fruit almost spherical and with a dense woolly pubescence

73. S. burkittii

$7^{*}$ Keel-tip narrow and conspicuously twisted; style-tip not laterally expanded

69. S. acuticarinata

64. S. disjuncta J. Thompson, sp. nov.

Herba prostrata perennis. Foliola 3-9 plerumque obovata. Racemi $3-16 \mathrm{~cm}$ longi floribus 7-10 mm longis. Calyx lobis tubo 2-plo longioribus. Vexillum versus basim lineis crassis. Carina subacuta. Stylus latus incrassatus apice geniculato pileis antrorsis. Fructus c. $10 \mathrm{~mm}$ longus c. $6 \mathrm{~mm}$ latus obovato-oblongus.

Type: Western Australia: c. $115 \mathrm{~km}$ E of Norseman on road to Balladonia, R. Pullen 9592, 23 Nov 1979; holo NSW; iso AD, BRI, CANB, PERTH.

A prostrate perennial with a number of stems from a slender taproot, their bases often below ground. Stems mostly 1-3 mm wide, shallowly angled or almost terete, with dense hairs, the hairs terete, broad-based or tubercle-based, basifixed, tapering to a very slender tip, of variable length but often $1 \mathrm{~mm}$ or more, antrorse or irregular and often twisted. Leaves $1.5-8 \mathrm{~cm}$ long, with 3-9 leaflets above an extended petiole, the leaflets obovate or occasionally almost cuneate, the pubescence loose, more sparse on the upper surface and moderately dense on the lower, the lateral leaflets variable in size, mostly 5-15 mm long and $2-10 \mathrm{~mm}$ wide, the terminal and lateral leaflets usually of approximately equal length, the leaflet-apex very broadly rounded, occasionally somewhat truncate or even retuse and usually with a small point. Stipules 3$8 \mathrm{~mm}$ long, very narrowly deltoid, with an extended apex, green, occasionally pale at the base, forming an abaxial ridge and with long hairs on both surfaces. Racemes 3$16 \mathrm{~cm}$ long, with 3-15 flowers of slightly dissimilar age. Peduncle $0.5-1.5 \mathrm{~mm}$ wide, with the pulvinus obscure, with flowers occupying the top $1 / 2$ or less, ribbed or terete, with dense but spaced spreading hairs. Bracts slender, $3-4 \mathrm{~mm}$ long. Flowers purple, red or pink, 7-10 mm long, on densely, not darkly, villous pedicels $1-3 \mathrm{~mm}$ long. Hypanthium very short and broad, not contracted at the top under the fruiting calyx, the bracteoles very long and narrow. Calyx with the tube c. $1 \mathrm{~mm}$ long, broadly and gradually expanding above the hypanthium, with long loose antrorsely spreading hairs, the lobes long-deltoid to narrowly ovate-acuminate, usually twice as long as the tube, not conspicuously uneven, the sinuses narrow. Standard 7-10 mm long and as wide or almost so, shortly tapering to the base, with two strong vertical thickenings. Wings 7-9 mm long, somewhat curved, obovate to broadly obovate, the apex obliquely and very shortly, obtuse, the upper part longer, the claw very short and strongly curved, the auricle rather narrow and long, recurved and folded. Keel 8$10 \mathrm{~mm}$ long and 3.5-4.5 $\mathrm{mm}$ deep, with the apex scarcely, but somewhat, acute and not swollen, not or scarcely twisted sideways, the upper margin straight or with a 
slight upcurve at the apex and base, the auricles rounded and as deep as the claw, without pockets, the claw untapered and straight. Ovary c. $4 \mathrm{~mm}$ long, elliptic, with a long very dense pubescence somewhat raised on the sutural side, obliquely and gradually tapering at the apex, more shortly and less obliquely at the base. Ovules numerous. Stipe somewhat less than $0.5 \mathrm{~mm}$ long, very broad, glabrous. Style often broad at the base, often unthickened there and rather narrow and terete but broader above where stiffened, sometimes stiffened and broadest at a laterally flattened base, above this gradually tapered, curved, especially near the middle, and pale and somewhat thickened, not or only slightly twisted, the tip narrowly rounded and bearing a stiff antrorse tuft of hairs below, but above a slender, curved, flexible, geniculate segment, the beard along the whole length including on the geniculate segment but irregularly developed and often sparse. Fruit c. $10 \mathrm{~mm}$ long and c. $6 \mathrm{~mm}$ wide, obovoid-oblong, tending to curve, somewhat dorsiventrally compressed, inflated with the suture somewhat and broadly intruded, shortly tapered at the base to a minute stipe and, at the apex, obtuse below a raised beak bearing the 4-5 $\mathrm{mm}$ style, pendulous to raised at maturity, with dehiscence seen only along the upper suture, with long, fine, spreading hairs on conspicuous but minute tubercles, the texture stiff, the veins obscure, probably at c. $60^{\circ}$, the tissue strong but not deep, deepest in the centre but not closing the loculus.

In three well-separated eremean areas; near the Fraser Range in southern Western Australia, in the adjacent corners of the Northern Territory and South Australia and adjoining part of Western Australia, and on the Eyre Peninsula. In red sandy soil, among rocks, especially at the foot of rocky ridges. Fig. 23.

This species is named for its disjunct distribution. From the Latin disjunctus, separate.

Selected specimens (from 20 examined): Western Australia: Fraser Range, $119 \mathrm{~km}$ E of Norseman, Phillips WA/68358, 3 Sep 1968 (CBG, PERTH). NORTHERN TERRITORY: on track between Mt Liebig Outstation \& Talapata Gorge, Corrick 10352, 8 July 1988 (MEL). South Australia: 13 miles [20 km] NW of Ernabella, Vasek 680918-38, 18 Sep 1968 (CANB); Mt Moulden inselberg, Barker 3147, 2 Sep 1978 (AD, NT); Mt St Mungo, Carrick 2415, 2 Oct 1969 (AD).

\section{S. flavicarinata J. Black}

\section{(J.M. Black 1924b: 319)}

Type: South Australia: Yunta, J.M. Black, 21 Oct 1917; lecto (fide Lee 1948: 235) AD; iso $\mathrm{AD}, \mathrm{K}, \mathrm{MEL}, \mathrm{NSW}$.

A prostrate or somewhat ascending perennial to $\mathrm{c} .45 \mathrm{~cm}$ high, with many stems from the, often stout and crown-like, top of a taproot. Stems $1.5-3 \mathrm{~mm}$ wide, almost terete or shallowly striate, with dense hairs, the hairs terete, rather turgid, broad-based or tubercle-based, basifixed, tapering to an extremely slender tip, of variable length, from less than 0.5 to more than $1 \mathrm{~mm}$ long but mostly c. $0.75 \mathrm{~mm}$ and usually reversed from the base but sometimes then spreading or even antrorse. Leaves $2-6 \mathrm{~cm}$ long, with 5-9 leaflets above an extended petiole, the leaflets obovate, the pubescence loose and often dense on the lower surface, the upper usually (but not always) virtually glabrous, the lateral leaflets usually $10-15 \mathrm{~mm}$ long and 5-10 $\mathrm{mm}$ wide, both the laterals and the terminal variable as to proportion, the leaflet-apex broadly rounded, occasionally somewhat retuse, with a small point. Stipules $3-7 \mathrm{~mm}$ long, narrowly deltoid with a long-acuminate tip, green, sometimes pale near the base, not forming an abaxial ridge and with long hairs on both surfaces. Racemes 2-15 cm long, with 3c. 15 flowers of slightly dissimilar age. Peduncle $0.5-1.5 \mathrm{~mm}$ wide, with the pulvinus obscure, with flowers occupying c. 1/2, ribbed, with dense but spaced spreading 
hairs. Bracts slender, 3-4 mm long. Flowers purple, red or pink with a greenish yellow keel, 8-10 mm long on densely (not dark) villous pedicels 1-2 mm long. Hypanthium very short and broad, with little contraction at the top under the fruiting calyx, the bracteoles long and rather narrow. Calyx with the tube c. $1 \mathrm{~mm}$ long, broadly but only gradually expanding above the hypanthium-top, with loose antrorse hairs, the lobes narrowly long-deltoid and long-acuminate, usually 3 or more times longer than the tube, not conspicuously uneven, the sinuses narrow. Standard 7-c. $10 \mathrm{~mm}$ long and 9$12 \mathrm{~mm}$ wide, abruptly tapering to a short slender claw with two strong vertical thickenings at the top. Wings (Fig. 4) 5-8 mm long, curved, obovate, the apex obliquely shortly obtuse, longer above, the claw very short and strongly curved, the auricle rather narrow, rather long, recurved and folded. Keel 7-9 mm long and c. $3 \mathrm{~mm}$ deep, with the apex rather acute and sometimes turned inward, with slight swellings below the tip and a very slight twist at the apex, with the upper margin upcurved near the apex but soon obviously turning downward to make a shallow curve to the deep rounded backwardly directed auricles and with indistinct pocket-like areas near the claw, the claw very long, slender untapered and straight. Ovary c. $3 \mathrm{~mm}$ long, elliptic, densely rather long-pubescent with the hairs raised near the suture or only near the base of the sutural side, obliquely and only slightly tapering at the apex and, somewhat and obliquely, more shortly tapering at the base. Ovules numerous. Stipe, somewhat less than $0.5 \mathrm{~mm}$ long, broad, glabrous, at least for the most part. Style very broad-based and laterally flattened from the base, tapering gradually, with a slight downward curve in the lower $1 / 2$ (or $1 / 3$ ), the upper $1 / 2$ or $2 / 3$ curved and evenly tapered, sometimes very pale and stiff but often less so or scarcely stiffened, slightly or conspicuously twisted there, the tip narrowly rounded and bearing a stiff antrorse tuft of hairs below, but above a slender curved flexible geniculate segment, the beard along the whole length including on the geniculate segment but irregularly developed and often sparse. Fruit mostly 10-15 mm long and c. $6 \mathrm{~mm}$ wide, curved, obovoid-oblong (smaller and almost spherical in specimens from Pedinga, S. Aust.), somewhat dorsiventrally compressed, inflated with the suture much or little and broadly intruded, shortly tapering at the base to a minute stipe and at the apex shortly obtuse below or behind a short erect beak bearing the c. $4 \mathrm{~mm}$ style or its broad base, pendulous to raised at maturity, dehiscing along the lower margin and the suture, with long fine spreading hairs on conspicuous but minute tubercles, the texture very stiff, the veins obscure, at c. $60^{\circ}$, the tissue deep in the centre but not always closing the loculus.

Mostly in the southern part of the Northern Territory but common in inland South Australia with outliers in adjacent parts of Western Australia, western Queensland and western New South Wales. Usually in deep red sand. Fig. 23.

Selected SPECIMENS (from c. 220 examined): Western Australia: 4 miles [6 km] W of Mt Tietkens, George 8963, 26 July 1967 (K, NT, PERTH). NORTHERN TERRITORY: 24 km S of Alice Springs, Stuart Highway, Maconochie 2411, 5 Sep 1978 (K, MEL, NT). South Australia: Pedinga, Ifould, 1880 (AD). QueEnSLAND: c. $35 \mathrm{~km}$ from Betoota, on road to Birdsville, Purdie 1280, 22 Aug 1978 (AD, BRI). New South WaLes: Kars Station, 40 miles [60 km] E of Broken Hill, Morris 746, 16 Oct 1921 (AD, BRI, K).

66. S. oligophylla F. Muell. ex Benth.

(G. Bentham 1864: 219)

TyPe: New SOUTH WALES: Darling River, Vict. Exped., 29 Sep 1860; lecto (fide Lee 1948: 184) MEL; iso $K$.

S. concinna Bailey (F.M. Bailey 1910: 286). Type: Queensland: Georgina River, E.W. Bick, Nov 1910; holo BRI. 
A prostrate, or occasionally ascending, perennial to c. $15 \mathrm{~cm}$ high, with numerous stems, often with their bases below the soil-surface, crowded at the top of a taproot. Stems usually 1-2 mm wide, with strong rather flattened ridges gradually expanding upward to the nodes, pubescent, the hairs well-separated, appressed, broad-elliptic, basifixed, subbasifixed and medifixed (on extensions), flat or turgid, less than $0.5 \mathrm{~mm}$ long and from rather blunt to somewhat pointed, often at both ends. Leaves $1-4 \mathrm{~cm}$ long, with 5-7 leaflets above a usually, but not always, extended petiole, the leaflets obovate, the often sparse minute, appressed pubescence lacking on the upper surface, the lateral leaflets mostly 2-15 $\mathrm{mm}$ long and 1-8 $\mathrm{mm}$ wide, varying within and between plants, the terminal often, but not invariably larger, the leaflet-apex shortly and broadly obtuse or retuse and often with a small point. Stipules c. $3 \mathrm{~mm}$ long, narrow and very long-tapering, green, widely separated and not forming an abaxial ridge and with hairs on outer surface and on the inner tip. Racemes $2-10 \mathrm{~cm}$ long, with 3-7 flowers of scarcely uneven age. Peduncle from less than $0.5-\mathrm{c} .1 \mathrm{~mm}$ wide, with the pulvinus conspicuous and usually rather dark, with flowers sometimes occupying c. $1 / 2$ but often much less of its length, i.e. often crowded near the tip, somewhat ridged or even flattened near the flowers, and with the minute appressed hairs more dense in the upper part. Bracts very narrow, to c. $3 \mathrm{~mm}$. Flowers purple, mostly 6-9 mm long, on densely to sparsely pubescent pedicels 1-3 mm long. Hypanthium (Fig. 2) short and broad, sometimes somewhat contracted at the apex under the fruiting calyx, the bracteoles very narrow, minute to $1 \mathrm{~mm}$ or more. Calyx (Fig. 2) with the tube c. $1.5 \mathrm{~mm}$ long, obliquely shortly and conspicuously expanding above the hypanthium-top, with a minute pubescence confined to ridges below and on the lobes, the lobes long-deltoid, long-attenuate and fine-tipped, 3-4 times longer than the tube and almost equal, the sinuses acute to narrowly rounded. Standard 8-10 $\mathrm{mm}$ long and as wide or a little narrower, rather abruptly tapering to a short broad claw, with a strong thickening at the base and a slight concavity above. Wings $\mathrm{c.} 7 \mathrm{~mm}$ long, almost obdeltoid, with the apex obliquely almost truncate with the upper edge longer, the claw very short, scarcely tapered and much curved, the auricle long, rather broad, rounded, twisted and recurved. Keel c. 8-9 $\mathrm{mm}$ long and $2 \mathrm{~mm}$ deep, obtuse, with slight swellings behind the tip and a slight twist behind this, with the upper margin almost straight or slightly raised to the rather deep, rounded, backwardly directed auricles with small pockets at their base, the claw long, slender, untapered and straight. Ovary c. 3-4 mm long, somewhat obliquely very narrowly ovoid-elliptic, with close appressed hairs, tapering to the apex and more suddenly at the base. Ovules numerous. Stipe c. $0.5 \mathrm{~mm}$ long and rather broad, glabrous at least for the most part. Style broad-based, the taper rather even below a sudden taper near the top close behind the more slender tip, very much flattened over the whole length, very slightly downcurved at the base before a strong upcurve at c. 1/3 from the base and beyond slightly curved, obviously twisted and somewhat thickened, pale, the tip very slender and curved, the beard usually irregular and for most of the length and more dense and stiff near the apex and on the tip. Fruit 10-12 mm long and 3-4 mm wide, oblong to subelliptic and a little curved, inflated but usually at least somewhat, but not always, dorsiventrally compressed, the suture variably intruded, contracting at the base above a minute stipe-like region, above a minute stipe, and, at the apex, rounded below, or tapering suddenly to, a raised recurved style of c. $4 \mathrm{~mm}$, raised or erect at maturity, with minute appressed hairs, dehiscent on both sides, the texture very thin and soft, the veins delicate, at c. $45^{\circ}$, the tissue even and very shallow, almost absent, the loculus usually but not always closed.

Widespread in the southern part of the Northern Territory, north-eastern South Australia, south-western Queensland and north-western New South Wales. Usually in clay-loam soils in better watered areas, especially on floodplain. Fig. 23. 
SELECTED SPECIMENS (from c. 140 examined): NoRTHERN TERRITORY: 28 miles [45 km] W of Argadargada H.S., Nelson 171, 27 Mar 1962 (CANB, K); Andado Station, $3 \mathrm{~km}$ W of East Bore, Henshall 577, 14 Aug 1974 (CANB, NT). South Australia: 2 km E of Anna Creek H.S., Badman 1275, 11 June 1984 (AD, CBG, MEL). QueENSLAND: Boulia, Blake 6481, 28 June 1934 (BRI, CANB). New SOUTH WALES: Fowlers Gap near Broken Hill, Jacobs 2101, 5 Oct 1975 (K, NSW).

\section{S. burkei F. Muell. ex Benth.}

(G. Bentham 1864: 218)

TYPE: NORTHERN TERRITORY: Burkes Creek, J. McDouall Stuart, 1862; lecto (fide Lee 1948: 237) MEL; iso (fragment) AD, K, NSW.

A prostrate or subshrubby perennial, to 30 or $40 \mathrm{~cm}$ high, with a stout taproot, the bases of the many branched stems often below the soil-surface. Stems (1-)2(-3) mm wide, usually scarcely striate, densely pubescent with rather turgid basifixed hairs, the hairs broad-based or tubercle-based and tapering to a slender tip, from c. 0.5 to more than $1 \mathrm{~mm}$ long, mostly antrorsely appressed after curving at the base from an often reversed position, occasionally loose or spreading and irregular and occasionally reversed. Leaves mostly $2-7 \mathrm{~cm}$ long, with 5-11 leaflets above a usually wellextended petiole, the leaflets oblong-elliptic to narrowly obovate, the pubescence long and usually loosely appressed, more sparse on or absent from the upper surface, the lateral leaflets mostly $10-30 \mathrm{~mm}$ long and 3-10 mm wide, the terminal usually somewhat longer, the leaflet-apex rounded with a minute point, or occasionally broadly acute. Stipules mostly 5-10 mm long, broad-based, obliquely ovate and long-acuminate, rarely, when very large, with lateral teeth, green, not forming an abaxial ridge and with long hairs on both surfaces. Racemes 1-c. $13 \mathrm{~cm}$ long, with 5-10 flowers of almost even age. Peduncle from less than $0.5-1.5 \mathrm{~mm}$ wide, with the pulvinus often conspicuous, sometimes dark, with flowers usually clustered near the top but sometimes occupying up to half, obscurely ribbed, densely pubescent with loose spreading or antrorse hairs. Bracts linear to lanceolate-acuminate, 3-10 $\mathrm{mm}$ long. Flowers purple (conspicuously striped in herbarium specimens), occasionally pink or white, c. $8 \mathrm{~mm}$ long, on villous pedicels $2-4 \mathrm{~mm}$ long. Hypanthium short and broad, not contracting at the apex under the fruiting calyx, the bracteoles linear. Calyx with the tube c. 1.5 $\mathrm{mm}$ long, gradually expanding above the hypanthium-top, with loose, spreading hairs, the lobes lanceolate to long-deltoid and variably long-acuminate, often three or more times longer than the tube, not conspicuously uneven, the sinuses narrow. Standard 9-11 mm long and as wide, contracting or tapering to a short, broad, tapered claw, with strong vertical thickening and a lateral curve of thickening containing two calli below it. Wings 6-8 $\mathrm{mm}$ long, the apex acute near the base and very obliquely truncate above so that almost triangular, the claw very short, broad and curved, the auricle very small, acute, narrow, twisted and recurved. Keel 7-9 mm long and 3-4 $\mathrm{mm}$ deep, with the apex round below an extended tip that is laterally narrow but dorsiventrally $1 \mathrm{~mm}$ or more in depth, and with a distinct broad swelling behind this, with the upper margin very thin in texture and irregular, with a slight upward curve from the tip to the rather small truncate or rounded auricles, and with pockets near the base, the claw long, rather broad, straight and untapered. Ovary 2-4 mm long, broadly subovoid-elliptic, rather flat-based, with a very long, loose pubescence; shortly and very obliquely tapering at the apex, and more shortly but obliquely contracted at the base. Ovules numerous. Stipe less than $0.5 \mathrm{~mm}$ long, very broad and glabrous, at least for the most part. Style stout, not twisted, the lower part tapering, almost straight then curved strongly to $90^{\circ}$ or even almost $180^{\circ}$, and unthickened, the upper $1 / 2-2 / 3$, pale, thickened with a groove below a dorsal ridge, almost straight behind a curved and then strongly infolded apex, with a lateral extension below the dorsal ridge near 
and on the curve and narrowing on the infolded tip, the beard short, stiff and antrorse on the flattened broadened area and very dense and tangled within the fold of the tip. Fruit mostly 8-15 mm long and 6-7 mm wide, oblong or a little wider at the apex or base, curved, usually dorsiventrally compressed, inflated with the suture broadly and deeply intruded, narrowing suddenly at the base above a minute broad stipe and rounded at the apex below or behind a minute upturned beak bearing the 4-5 $\mathrm{mm}$ style, pendulous or raised to a varying extent at maturity, dehiscent at the suture, with long, fine, spreading hairs from scarcely perceptible tubercles, the texture leathery to stiff, the veins not or slightly raised at $c .60^{\circ}$, the tissue deep in the centre and probably closing the loculus.

Widespread in the central part of the Northern Territory and in western Queensland. In a variety of soils from cracking clay to red sand, in grassland or woodland, sometimes associated with limestone. Fig. 23.

SELECTED SPECIMENS (from c. 115 examined): NORTHERN TERRITORY: $3.2 \mathrm{~km}$ SW of Dalmore Downs, Chippendale 7325, 21 June 1960 (AD, BRI, CANB, K, NSW, NT); Lake Surprise area, Henry 627, 10 Mar 1975 (K, NSW, NT); 4 miles [6 km] E of No. 6 Bore, Mannero Green, Chippendale 1147 (K, NSW, NT). QUEENSLAND: 41 miles [65 km] NE of Camooweal, on road to Thorntonia, Ollerenshaw 1305 \& Kratzing, 10 July 1974 (CBG, NT).

\section{S. rostrata J. Thompson, sp. nov.}

Herba prostrata vel humilis annua vel perennis usque ad c. $10 \mathrm{~cm}$ alta. Foliola 7-9 obovata. Racemi 3-12 cm longi floribus c. $8 \mathrm{~mm}$ longis. Calyx lobis valde longiacuminatis tubo 2-3-plo longioribus. Vexillum versus basim irregulariter crassatum. Carina acuta extremo membranaceo. Stylus incrassatus cresta rigida apice complanato et valde incurvato. Fructus $10-20 \mathrm{~mm}$ longus 3-5 mm latus anguste oblongus.

TyPe: Northern TerrITory: Burt Plain, $57 \mathrm{~km}$ N of Alice Springs, D.J. Nelson 198, 3 Mar 1962; holo NSW; iso CANB, K, NT.

A prostrate or low-growing annual or perennial, to $\mathrm{c} .10 \mathrm{~cm}$ high, with numerous slender stems from the top of a taproot, sometimes with the stem-bases below the soil-surface. Stems usually c. $1 \mathrm{~mm}$, occasionally to $2 \mathrm{~mm}$, wide, somewhat ridged from below the nodes, pubescent, often sparsely except on young parts, the hairs appressed to loosely appressed, rather turgid, often with a minutely tuberculate base, tapering, pointed, basifixed and mostly $0.5 \mathrm{~mm}$ or less in length but with scattered longer hairs. Leaves mostly 1-4 cm long, with 7-9 leaflets above a variably, often well, extended petiole, the leaflets obovate, sometimes narrowly so, the pubescence of the lower surface variable in density and appression, the upper surface virtually glabrous, the lateral leaflets mostly 3-10 $\mathrm{mm}$ long and 2-6 mm wide, the terminal usually a little longer and sometimes wider, the leaflet-apex very broadly obtuse or, occasionally, broadly acute, with a small point variably developed. Stipules $1.5-4 \mathrm{~mm}$ long, usually obliquely and narrowly deltoid and long-acuminate, green, widely separated at the base, not forming an abaxial ridge and with hairs on both surfaces. Racemes 3-12 cm long, with 1-5(-12) flowers of almost even age. Peduncle from less than $0.5-1 \mathrm{~mm}$ wide, with the pulvinus usually conspicuous, sometimes dark, with flowers mostly clustered near the top, rarely occupying $1 / 3$, obscurely ribbed or smooth, with a sparse antrorse, sometimes appressed, pubescence, dense near the flowers. Bracts narrowly lanceolate, $2-3 \mathrm{~mm}$ long. Flowers purple and/or cream, usually c. $8 \mathrm{~mm}$ long, on sparsely pubescent pedicels c. $2 \mathrm{~mm}$ long. Hypanthium short and broadly expanding, not contracting at the apex under the fruiting calyx, the bracteoles minute and linear. Calyx with the tube c. $1.5 \mathrm{~mm}$ long, a little swollen and then expanding gradually above the hypanthium-top, with a sparse antrorse pubescence, 
the lobes deltoid and very long-acuminate, usually twice to three times as long as the tube, not conspicuously uneven, the sinuses narrow. Standard 8-10 $\mathrm{mm}$ long and 9$12 \mathrm{~mm}$ wide, contracting or tapering suddenly to a short broad tapered claw, with a strong irregular thickening at the base. Wings 5-7 mm long, the apex rather acute near the base and then curved upward and inward to a peak on the central upper margin so as to appear almost triangular, the claw very short broad and curved, the auricle very small, rounded, recurved and twisted. Keel 8-9 mm long and 3-4 mm deep, with the apex acute with a broadly extended tip of thin-textured material around it forming a snout-like structure c. $2 \mathrm{~mm}$ in depth but laterally flattened, with a broad swelling behind this tip, with the upper margin with a gentle upward curve between the tip and the very short shallowly rounded auricles, and with pockets near the base, the claw long broad straight and untapered. Ovary c. $3 \mathrm{~mm}$ long, narrowly elliptic to linear, with very long loose hairs, absent from the lower margin; tapering slightly and obliquely at the apex and slightly to negligibly at the base. Ovules numerous. Stipe less than $0.5 \mathrm{~mm}$ long, very broad, and glabrous at least in part. Style stoutbased, not twisted, tapering for c. 1/2 its length and unthickened, with a curve at the top of this region, above stiffened and pale with a distinct dorsal ridge above a groove, straight for a short distance and then forming a strong curve so that the tip is often close, with a lateral extension below the dorsal ridge below and on the curve and narrowing at the tip, the beard often very long, occasionally short or absent, on the flattened region towards the apex, usually dense within the abaxial curve. Fruit 10-20 mm long and 3-5 mm wide, narrowly oblong, curved, usually somewhat dorsiventrally compressed, inflated, with the suture deeply and broadly intruded, narrowing at the base to a minute stipe and, at the apex, tapering rather abruptly to a short straight beak, or sometimes upturned and obtuse below the beak bearing the $c$. $5 \mathrm{~mm}$ style, raised at maturity, dehiscent at the suture, with very long and fine, scattered, tubercle-based hairs, the texture stiff, the veins delicate at $c .45^{\circ}$, the tissue deep, especially in the centre, and closing the loculus.

Mostly in the southern part of the Northern Territory but in adjacent South Australia and with disjunct occurrences in inland Queensland. In heavy red soil on stony open plain, often with Mitchell Grass or mulga. Fig. 23.

This species is named for the shape of its keel-tip. From the Latin rostratus, beaked.

Selected sPeCimens (from c. 25 examined): Northern Territory: Central Mt Wedge Station, Latz 6714, 29 Nov 1976 (NT); Finke River, Kempe, 1889 (MEL); 8.5 miles [13.5 km] S of Deep Well township, Lazarides 5757, 19 Aug 1956 (AD, BRI, CANB, NT). SOUTH AustraLIA: Ernabella, Turvey, 20 Apr 1967 (NSW). QueENSLAND: Winton-Jundah road, $148 \mathrm{~km}$ N of Jundah, Williams 81193, 29 July 1981 (BRI).

\section{S. acuticarinata (A. Lee) J. Thompson, comb. nov.}

BASIONYM: S. burkei F. Muell. ex Benth. subsp. acuticarinata A. Lee, Contr. New South Wales Natl. Herb. 1(4):239 (1948).

TyPe: South Australia: Camp 10, R. Helms 140, 27 June 1891; holo NSW; iso AD, K, MEL.

A prostrate perennial to c. $45 \mathrm{~cm}$ high, with a number of stems from a stout taproot, their bases often below the soil-surface. Stems (1-)2(-4) mm wide, often conspicuously ridged from the nodes, densely pubescent, the hairs very fine, spreading, basifixed, often from below a distinct tubercle, c. $1 \mathrm{~mm}$ long and tapering to an extremely fine tip. Leaves 1-3(-5) mm long, with 5-11 leaflets above an extended petiole, the leaflets obovate to almost cuneate, the pubescence long and spreading, dense on the lower 
surface and absent, or almost so, from the upper, the lateral leaflets usually 5-15 $\mathrm{mm}$ long and $3-7 \mathrm{~mm}$ wide, both the laterals and the terminal variable as to proportion, the leaflet-apex usually retuse or emarginate, sometimes with a minute point. Stipules 3-7 $\mathrm{mm}$ long, very obliquely, and often broadly, ovate-acuminate, with the outer margin sometimes lobed, green, not forming an abaxial ridge or with the ridge present as a line of hairs or even a collar, and with long hairs on both surfaces, occasionally confined to the margins. Racemes 1-15 cm long, with 2-10(-15) flowers of only slightly uneven age. Peduncle from less than 0.5-1 mm wide, with the pulvinus absent, with flowers occupying c. $1 / 2$ its length, conspicuously ridged, with long, dense, spreading, sometimes conspicuously tubercle-based, hairs. Bracts lanceolate, 2-3 mm long. Flowers purple, sometimes with the keel-tip pale, $7-10 \mathrm{~mm}$ long, on villous pedicels c. $2 \mathrm{~mm}$ long. Hypanthium broad at the apex, narrow below, not contracted at the apex under the fruiting calyx, the bracteoles long and narrow. Calyx with the tube c. $1.5 \mathrm{~mm}$ long, gradually expanding above the hypanthium-top, with loose and sometimes well-spaced long spreading hairs, the lobes narrow-lanceolate and longattenuate, usually three or more times longer than the tube, not conspicuously uneven, the sinuses very narrow and acute. Standard 7-11 $\mathrm{mm}$ long, and 8-10 mm wide, somewhat rounded above a very short tapered claw, with a small much-thickened area at the base. Wings $4.5-7 \mathrm{~mm}$ long, obovate, much curved, the apex obliquely obtuse, longer above, the claw very short and strongly curved, the auricle rather long, recurved and folded. Keel 6-10 mm long and 3-4 mm deep, with the apex forming an acute upwardly extended and often twisted beak, rounded and somewhat inflated below this, with the upper margin almost straight from the narrow tip to the deltoid deep and backwardly directed auricles, with shallow folds near the auricle bases, the claw short, slender, untapered and straight. Ovary 2-4 mm long, elliptic, with a dense long loose pubescence, tapering, slightly obliquely, at the apex and more obliquely and shortly at the base. Ovules numerous. Stipe somewhat less than $0.5 \mathrm{~mm}$ long, broad, glabrous, at least for the most part. Style rather stout, not very broad-based, unthickened or slightly thickened in the upper part, and with an even taper, almost straight in the lower part, then upcurved with a gradual curve to the strongly incurved tip and often a twist in the upper part, the tip rather broadly truncate with an arc of short hairs behind it, the beard dense and along the whole length but short in the upper part. Fruit mostly 10-15 mm long and c. 4-5 mm wide, oblong or a little wider at the apex or base, curved, usually dorsiventrally compressed, inflated, with the suture usually much and broadly intruded, shortly tapered at the base to a minute stipe and at the apex tapering to, or rounded below, an upcurved beak bearing the $c$. $5 \mathrm{~mm}$ style or its remains, raised to a variable extent at maturity, dehiscent along the suture and below the tip on the other side, with very long, fine, spreading hairs from scarcely perceptible tubercles, the texture softly leathery to very stiff, the veins raised to give a strong reticulation, at $60^{\circ}$ to almost $90^{\circ}$, the tissue deep in the centre and closing the loculus.

In western South Australia, the south-western part of the Northern Territory and scattered in eastern Western Australia. In red sandy soil with Triodia spp. and often scattered mallee or mulga; associated with limestone. Fig. 23.

This species is distinct from $S$. burkei, though obviously related to that species.

SELECTED SPECIMENS (from c. 35 examined): WeStern Australia: c. $78 \mathrm{~km}$ E of Warburton, George 12019, 19 July 1974 (PERTH). NorThern TERRITORY: SE side of Mt Conner, Beauglehole 22855, 28 June 1967 (MEL, NSW); 21 miles [34 kms] NNE of Alice Springs Township, Perry 3343, 7 Mar 1953 (CANB, NT). South Australia: Mt Davies road, c. $70 \mathrm{~km} \mathrm{~W} \mathrm{of} \mathrm{Musgrave} \mathrm{Park} \mathrm{Station,}$ Weber 206, 30 Oct 1966 (AD); $23 \mathrm{~km} \mathrm{NE}$ of Poochera, directly N of Karcultaby, Chinnock 2912, 20 Oct 1975 (AD). 
70. S. canescens (Benth.) F. Muell.

(F. Mueller 1862: 46)

BAsIONYM: Cyclogyne canescens Benth. (Bentham in J. Lindley 1839: 16).

Type: Western Australia: Swan River, J. Drummond, 1839 (herb. Benth.); BM, K.

S. canescens var. horniana J. Black (J.M. Black 1924a: 318). TYPE: NORTHERN TERRTTORY: Glen Helen Gorge, MacDonnell Range, R. Tate, herb. Tate, 1894; holo AD; iso NSW.

A prostrate or low-growing perennial to $c .50 \mathrm{~cm}$ high, with several branched stems arising from a taproot. Stems usually 5-6 mm wide, often strongly flexuose, ridged or angled, densely pubescent, the hairs extremely fine, spreading, c. $1 \mathrm{~mm}$ long, often irregular or crisped, tapering to a very slender point, and basifixed. Leaves usually $10-15 \mathrm{~cm}$ long, with 9-15 leaflets above a variously extended, often short, petiole, the leaflets often broadly ovate but frequently broadly elliptic or obovate, with a dense loose pubescence sometimes absent from the upper surface, the lateral leaflets usually 10-35 mm long and 5-20 mm wide, conspicuously decreasing in size towards the tip, the terminal sometimes longer than the upper laterals, the leaflet-apex very broad and shortly obtuse, retuse or emarginate, with a short point. Stipules usually 5-15 mm long, obliquely deltoid or ovate, usually long-acuminate, occasionally with obscure teeth on both sides, green or scarious, forming a distinct abaxial collar and densely pubescent on both surfaces. Racemes usually 10-25 cm long, with c. 15-40 flowers of very disparate age. Peduncle $1.5-3 \mathrm{~mm}$ wide, without a pulvinus, with flowers dense in the upper $1 / 2$ to $2 / 3$ of its length, ribbed, densely pubescent. Bracts narrowly linear-lanceolate, 3-7 mm long. Flowers in various shades of purple, occasionally with a greenish yellow standard, 8-12 $\mathrm{mm}$ long, on densely pubescent pedicels of $1 \mathrm{~mm}$ or less. Hypanthium short and broad, not contracting at the apex under the fruiting calyx, the bracteoles long and narrow. Calyx with the tube c. $2 \mathrm{~mm}$ long, usually rather narrowly expanding above the hypanthium-top, densely pubescent, the lobes deltoid, very variable at their apices, from acute to long-attenuate, usually 2-3 or more times the length of the tube, the upper lobes shorter and broader than the lower, the sinuses rather narrowly rounded. Standard 7-12 $\mathrm{mm}$ long and often just a little broader or narrower, tapering or somewhat contracting to a very short broad tapered claw, with two rather variably, sometimes scarcely, developed horizontal calli at the base. Wings 6-9 mm long, curved oblong, the apex rounded (and not expanded), the lower edge rather expanded at the base of the short broad tapered curved claw, the auricle large, long, rounded and recurved, and folded at the base. Keel (Fig. 5) 8-11 mm long and 2.5-5 mm deep, with the apex rather acute and with two conspicuous swollen boss-like appendages each side of and hiding the tip, with the margin, behind this, with a slight curve in front of the long rounded backwardly directed auricles, without pockets, the claw rather short and broad, untapered and straight. Ovary c. $4 \mathrm{~mm}$ long, obliquely ovoid-elliptic, with dense, fine, long, loosely antrorse hairs; tapering abruptly or contracting obliquely at the base, the apex tapering more gradually. Ovules numerous. Stipe c. $0.5 \mathrm{~mm}$ long, broad, glabrous. Style (Fig. 6) unthickened, not twisted, rather broad-based and tapering gradually, curved, especially above the broad base but more slightly above, and sharply incurved at the tip, laterally flattened in the middle area but on the in-curling tip spreading laterally and with a dorsal ridge, the beard dense often over the whole length, very dense in the curve of the tip. Fruit 8-25 $\mathrm{mm}$ long and 4-6 mm wide, narrowly to broadly oblong, dorsiventrally compressed, inflated with the suture rather broadly and variably intruded, at the base abruptly contracted to a minute stipe, at the apex rather shortly tapering to, or rounded behind, a minute slender beak bearing the curved $c$. $5 \mathrm{~mm}$ style, becoming raised to erect at maturity, dehiscent at the suture, the pubescence dense and fine, short and antrorse to long rather crisped and spreading, the 
texture softly leathery, the surface obscured by the dense hairs but appearing smooth with minute tubercles, the veins probably at c. $90^{\circ}$, the tissue varying in depth with the loculus open or closed.

Widespread in eremean parts of Western Australia, western South Australia and the Northern Territory. In red sandy soil, often in shrubland or mallee woodland. Fig. 24.

SELECTED SPECIMENS (from c. 235 examined): WESTERN AUSTRALIA: 52 miles [83 km] NE of Laverton, George 8099, 28 Sep 1966 (CANB, NT, PERTH); between Kalgoorlie \& Coolgardie, Aplin 1897, 10 Sep 1962 (K, MEL, PERTH). NoRTHERn TERrITORY: 24 miles [38 km] NE of Undoolya Station, Perry 3285, 6 Mar 1953 (BRI, CANB, K, NSW, NT); 9 miles [14 km] W of Alice Springs Township. Perry 5367, 4 Sep 1955 (BRI, CANB, K, NSW). South Australia: Cook-Vokes Corner, c. 30 $\mathrm{km}$ S of Vokes Corner, Weber 6402, 21 Aug 1980 (AD, MEL, NSW).

\section{S. incei Price}

(Price 1910: 382)

Type: Western Australia: Probably Mt Sir Samuel, W.H. Ince; holo K.

An erect or ascending annual, perhaps occasionally perennial, said to reach $3 \mathrm{~m}$ high but often $25 \mathrm{~cm}$ or less, with numerous stems and a taproot. Stems $2-8 \mathrm{~mm}$ wide, often strongly ridged or irregularly angled, often with crowded internodes, with extremely fine antrorsely, sometimes loosely, appressed hairs, the hairs $0.5-1 \mathrm{~mm}$ long, terete, tapering to a long fine point and basifixed. Leaves mostly $5-8 \mathrm{~cm}$ long, with 5-9 leaflets above a usually much elongated petiole, the leaflets lanceolateelliptic, with an appressed pubescence sometimes absent from the upper surface, the lateral leaflets mostly $10-30 \mathrm{~mm}$ long and 3-10 mm wide, the terminal sometimes a little longer, the leaflet-apex acute to acuminate, with a distinct recurved point; the lower leaves with broad and more obtuse leaflets. Stipules $5-8 \mathrm{~mm}$ long, deltoid at the base but with long, narrow, attenuate spreading tips, green or scarious, separated, usually with the formation of an, often deep, abaxial ridge or collar, and glabrous or pubescent, especially on the inner surface. Racemes 2-30 (said to reach 80 ) $\mathrm{cm}$ long, usually with 10-20 flowers of disparate age. Peduncle mostly $0.5-1 \mathrm{~mm}$ wide, without a pulvinus, with flowers usually occupying $1 / 2$, occasionally more, of its length, somewhat ridged, with appressed hairs. Bracts lanceolate, 2-3 mm long. Flowers purple, 10-12 mm long, on pubescent pedicels 1-2 mm long. Hypanthium short, often rather narrow below the broad top, slightly contracting at the apex under the fruiting calyx, the bracteoles often conspicuous, narrow. Calyx with the tube c. $2 \mathrm{~mm}$ long, expanding rather obliquely above the hypanthium-top, pubescent with fine antrorsely spreading irregular hairs, the lobes narrowly deltoid and acuminate, equal to, or, especially the longer narrower lower lobes, somewhat longer than the tube, the sinuses, especially the upper, very broad. Standard 10-15 $\mathrm{mm}$ long and 13-15 $\mathrm{mm}$ wide, tapering to a short tapered claw or to the base, with two weak to strong angled thickenings near the base and a somewhat concave area above them. Wings 7-9 $\mathrm{mm}$ long, somewhat oblong, with the apex obliquely rounded, the lower edge longer, expanded and pale, the claw short tapered and curved, the auricle deep rounded deltoid and somewhat raised. Keel 8-11 $\mathrm{mm}$ long and 3-4 mm deep, with the apex narrowly obtuse with two large shallow pouches below the broadly rounded tip, with the upper margin curving upward at the apex and then almost straight before slanting slightly downward at the long deltoid backwardly directed auricles, without obvious pockets, the claw very short, tapered and straight or a little recurved. Ovary c. $4 \mathrm{~mm}$ long, strongly curved, ovate-elliptic, with a long pubescence, loosely appressed near the apex, the apex obliquely narrowly obtuse, the base contracted from the top. Ovules numerous. Stipe c. $0.5 \mathrm{~mm}$ long, slender, straight, glabrous at least for the most part. Style slender, narrow-based but above the base the top c. $2 / 3$ a little 
broader, laterally flattened and untapered, all only shallowly and rather evenly curved, the tip tapering on both sides, with a line of hairs behind it and a mass of antrorse hairs around it in front of this, the beard dense and antrorse, in the upper part. Fruit mostly c. $15 \mathrm{~mm}$ long and $5-7 \mathrm{~mm}$ wide, narrowly obovoid-elliptic, variably inflated and usually strongly dorsiventrally compressed, at the base tapering until very narrow and stipe-like near the minute stipe and at the apex rounded below a minute beak bearing the reflexed c. $4 \mathrm{~mm}$ style, variously raised or pendulous at maturity, dehiscent on both sides of the tip and along the sutural side, the pubescence soft and spreading, the texture thin and rather brittle, the venation delicate, at c. $60^{\circ}$, the tissue short and even, sometimes closing the loculus.

In eremean parts of central Western Australia. In well-drained sandy or gravelly soil, often with mulga. Fig 24.

Selected specimens (from c. 20 examined): Western Australia: Paraburdoo, Boomsma 633, 6 Aug 1980 (AD); Windidda Homestead, Speck 1249, 19 Aug 1958 (AD, CANB, MEL, NSW, NT); bore No 6 of Melrose, Beard 6540, 13 Sep 1973 (NSW, PERTH); 4 miles [6 km] S of Agnew, Aplin 2357, 18 Aug 1963 (PERTH); 2 miles [3.2 km] N of Lawlers, Gardner, 1 Oct 1945 (PERTH).

\section{S. tephrotricha F. Muell.}

\section{(F. Mueller 1852: 392)}

TYPe: SOUTH Australia: Burra Burra, Nov. Holl. austr. interior, F. Mueller; lecto (fide Lee 1948: 188) MEL; iso AD, NSW. I have not found the specimen Bentham (1864) cited as Burra Burra at K; it may be the one labelled Nov. Holl. austr. int., F. Muell., herb. Sonder.

S. lessertiifolia var. tephrotricha (F. Muell.) Benth. (G. Bentham 1864: 227). Type: as for the species.

An erect or ascending subshrubby perennial to $c .1 \mathrm{~m}$ high, with several stems or sometimes with complex branching from the top of a taproot. Stems to $10 \mathrm{~mm}$ or more in width, irregularly, often strongly, ridged or angled from the nodes, the hairs dense, mostly $0.5-1 \mathrm{~mm}$ long, narrowly elliptic with long tapering pointed ends, some appressed but many with the ends irregularly twisted and raised, flattened, medifixed, often asymmetrically, often raised above the surface at the point of attachment and few to many dark. Leaves mostly 5-10 cm long, occasionally to more than $15 \mathrm{~cm}$, with 7-19 leaflets above an often but not always extended petiole, the leaflets broadly ovate to narrowly elliptic, with a dense close pubescence on both surfaces, the lateral leaflets mostly $10-30 \mathrm{~mm}$ long and 3-10 $\mathrm{mm}$ wide, the terminal variable but usually shorter than the shorter upper laterals, the leaflet-apex rounded or broadly acute, with an, often minute, usually recurved, point. Stipules $5-8 \mathrm{~mm}$ long, usually lanceolate, green, usually, but not invariably, not forming an abaxial ridge and pubescent on both surfaces. Racemes mostly 10 to more than $30 \mathrm{~cm}$ long, often with 30 or more flowers of uneven age. Peduncle mostly 2-3(-4) mm wide, without a pulvinus, with flowers in the upper $1 / 2$ or occasionally $2 / 3$, usually ribbed, densely pubescent with rather crisped, often dark hairs in the upper part. Bracts ovate or lanceolate, c. $3 \mathrm{~mm}$ long. Flowers pink or pinkish purple, occasionally white, 8-12 mm long, on densely, often dark, pubescent pedicels 1-3 mm long. Hypanthium rather slender, somewhat contracted at the apex under the fruiting calyx, the bracteoles narrow but variable in length. Calyx with the tube $2-3 \mathrm{~mm}$ long, gradually but obliquely expanding above the hypanthium, with a dense, often very dark, somewhat irregularly crisped, loosely appressed pubescence, the lobes deltoid-acuminate, often rather narrow above the base, usually much shorter than the tube, not very dissimilar or the upper shorter and broader, the sinuses broad and rounded. Standard c. 8-12 mm long 
and 10-12 mm wide, usually gradually tapered to a tapered claw, occasionally with thickened lines, usually unthickened. Wings c. 8-10 mm long, oblong with a shortly rounded apex, the claw rather long, curved and very slender, the auricle deep and rounded or truncate. Keel c. 9-10 mm long and 3.5-4 mm deep, with the apex rather narrow and obtuse, sometimes a little upturned, with the upper margin usually almost straight, and with long shallow pockets, the claw not very long, slender, the auricles deep and deltoid, and backwardly directed. Ovary c. $4 \mathrm{~mm}$ long, curvedelliptic, with a mostly short, loosely appressed pubescence, dense and long along the suture and somewhat erect towards its base; a little tapering at the apex behind a broad-style base and gradually tapering a little to the base. Ovules numerous, but many aborted. Stipe negligible to c. $0.5 \mathrm{~mm}$, glabrous. Style broad-based and much laterally compressed, not twisted, tapering rather evenly with the long slender tip more tapered and usually incurved or inflexed, the style-curvature slight near the base, a little stronger in the upper part where sometimes somewhat thickened, an erect tuft of fine hairs on the slender tip behind the apex, the beard scattered below and dense in the upper part and on the tip. Fruit 10-15 $\mathrm{mm}$ long and 7-8 mm wide, subglobose, much inflated with the suture not or scarcely intruded, at the base shortly tapering to a minute or negligible stipe, at the apex rounded below and sometimes beyond a minute upturned beak with the c. $6 \mathrm{~mm}$ recurved style or its stout base, pendulous or occasionally lifting somewhat at maturity, the dehiscence at the base on the sutural side, with dense, erect, crisped, short, often dark hairs, the texture stiffly leathery, the surface smooth with fine veins at $90^{\circ}$, the tissue well-developed at the base of the funicles in the centre of the suture.

In the Flinders Ranges area of eastern South Australia. On rather arid hillsides, often on roadsides. Fig. 24.

SEleCtED SPECIMENS (from c. 25 examined): South Australia: Arkaroola, Kuchel 3113, 14 Sep 1973 (AD); $13 \mathrm{~km} \mathrm{~N}$ of Wilpena Chalet, Sikkes 795 \& Ollerenshaw, 23 Sep 1973 (AD, CBG, NSW); Panaramitee, S of Yunta, Gemmell 409, 2 Sep 1980 (AD); E of Eudunda, Boehm 404, 30 Sep 1963 (AD); just $S$ of outskirts of Eudunda, Symon 13222, 17 Aug 1983 (CANB, K, NSW).

\section{S. burkittii F. Muell. ex Benth.}

(G. Bentham 1864: 218)

TyPE: NEw South Wales: between the Lachlan and Darling Rivers, Burkitt; lecto (fide Lee 1948: 239) MEL; iso K, NSW.

An erect or procumbent perennial, often forming a bush c. $1 \mathrm{~m}$ high, with several to many stems from a taproot; the vegetative parts with a rank odour. Stems (2-)3-6 mm wide, often conspicuously flexuose, ridged, the pubescence dense, close and crisped with emergent spreading straighter hairs, the hairs mostly c. $1 \mathrm{~mm}$ long, extremely fine, somewhat flattened, tapering to a very fine tip and basifixed. Leaves (2-)8-15 cm long, with (7-)15 to more than 30 leaflets above a variable, often short, petiole, the leaflets usually broad-oblong, occasionally obovate or almost orbicular, with a loose pubescence on both surfaces, occasionally much less on the upper, the lateral leaflets mostly 2-15 $\mathrm{mm}$ long and 2-10 $\mathrm{mm}$ wide, conspicuously decreasing in size towards the apex, the terminal usually approximately the same size as the much smaller upper laterals, the leaflet-apex broadly rounded, retuse or emarginate, the point negligible. Stipules 3-6 mm long, obliquely deltoid to ovate-acuminate, the outer margin rather erose, green, usually with at least some sign of an abaxial ridge, and densely pubescent on both surfaces. Racemes mostly $10-25 \mathrm{~cm}$ long, with up to 50 flowers of very disparate age. Peduncle from less than 1-2 $\mathrm{mm}$ wide, without a pulvinus, the flowers occupying $3 / 4$ or the whole length, closely ribbed, densely pubescent. Bracts linear-lanceolate, c. $3 \mathrm{~mm}$ long. Flowers $8-10 \mathrm{~mm}$ long, usually very dark reddish 
purple, rarely white, on densely pubescent pedicels c. $1 \mathrm{~mm}$ long. Hypanthium short, not contracted at the apex under the fruiting calyx, the bracteoles narrow. Calyx with the tube c. $2 \mathrm{~mm}$ long, expanding above the hypanthium-top but not much beyond this, with a dense long rather antrorsely spreading pubescence, the lobes lanceolatedeltoid, rather variably long-attenuate, usually longer, often much longer, than the tube, the sinuses broad. Standard 8-11 $\mathrm{mm}$ long and either a little narrower or broader, rounded or tapered above a very short tapered claw, with two often strong, horizontal calli or ridges at the base. Wings (Fig. 4) $5-8 \mathrm{~mm}$ long, narrow and somewhat cultrate, the apex acute, upcurved and tapering to a narrow tip, the lower edge upcurved a little in front of a downwardly curved and then raised short broad and much tapered claw, the auricle deep, broad, rounded and recurved, and strongly twisted at the base. Keel 7-10 $\mathrm{mm}$ long and 2-3.5 mm deep, with the apex acute with a somewhat variably developed small split beak of softened undulating tissue at the tip, not twisted, sometimes swollen below this, with the upper margin usually curving downward behind the tip and beyond this either straight or with a variable curve to the deeply truncate auricles, and without conspicuous pockets, the claw rather long, broad with little taper and slightly curved, obviously separated at the base. Ovary c. $3 \mathrm{~mm}$ long, ovate-elliptic, with a very dense and long loosely antrorse pubescence, the apex obliquely tapering, the base more abruptly but obliquely tapering. Ovules c. 8 but few developing. Stipe c. $0.5 \mathrm{~mm}$ long, broad, glabrous. Style slender, with some taper behind a strongly curved or closely coiled and somewhat broader apex, with thickening and with a rather even curvature below the tip, not twisted, without hairs but with a rather acute ridge on the coiled area, the beard sparse except on the somewhat flattened area near the tip and inside the coil. Fruit 5-8 mm long and about as wide, almost spherical but often somewhat flattened on the sutural side with the suture much intruded, much inflated, at the base abruptly tapering to the minute stipe, at the apex broadly and obliquely rounded behind a minute upturned beak bearing the recurved 4-5 mm style, spreading or pendulous at maturity, dehiscent at the suture, breaking readily into two, the pubescence very dense, soft, long and spreading, the texture softly leathery, the surface obscured by the dense hairs but often raised in low ridges and with minute tubercles, the veins probably at c. $90^{\circ}$, the tissue deep and even, at least sometimes sealing the loculus.

Widespread in western New South Wales with an outlying population north of Spencers Gulf in South Australia. Usually in red sandy or loamy soils on open plain, or in shrubland or sparse woodland. Fig. 24.

Selected specimens (from c. 110 examined): South Australia: between Parachilna \& Nilpena, Eichler 13010 (AD, K); Parachilna, Lothian 1468, 17 Sep 1955 (AD, BRI, NSW, NT). New SoutH Wales: Bulla Bulla, $145 \mathrm{~km}$ E of Wilcannia, Morris 2245, 6 Oct 1928 (AD, BRI, K); WilcanniaCobar road, Constable NSW 4530, 16 Oct 1947 (BM, K, NSW); Sayers Lake, c. $195 \mathrm{~km}$ ESE of Broken Hill on railway, Milthorpe 209, 1 Nov 1970 (AD).

\section{Group 12}

1 Keel-apex forming an upwardly directed beak; style less than $10 \mathrm{~mm}$ long with the beard absent and a long ridge of rather stiff hairs extending behind the tip $\quad \ldots \quad 74$. S. plagiotropis

1* Keel-apex recurved or curled; style more than $10 \mathrm{~mm}$ long, bearded but with hairs behind the stigma fine and inconspicuous or absent

2 Stem-hairs c. $0.5 \mathrm{~mm}$ long and spreading; keel strongly curved but not making a full circle 75. S. swainsonioides

2* Stem-hairs minute and appressed; keel curled so as to loop back on itself and extend forward 
74. S. plagiotropis F. Muell.

(F. Mueller 1875: 153)

TYPE: VICTORIA: Campaspe River, F. Mueller, Oct 1875; holo MEL; iso K, MEL, NSW.

A prostrate perennial to $c .15 \mathrm{~cm}$ high, with a number of stems from a complex below-ground branching system. Stems of variable width, mostly 2-4 mm wide, almost terete, glabrous or with sparse hairs c. $0.5 \mathrm{~mm}$ long or occasionally minute, tapering to a narrow apex, appressed or sometimes loosely antrorse and basifixed or subbasifixed. Leaves (2-)5-12 cm long, with 13-25 leaflets above a usually, but not invariably, extended petiole, the leaflets mostly narrowly obovate to narrow-lanceolate, with scattered hairs on the lower surface, the lateral leaflets mostly 10-15 mm long and 1-4 mm wide, the terminal usually approximately equal to the short upper laterals, the leaflet-apex often tapering, occasionally rounded, and recurved and pointed. Stipules 5-9 mm long, obliquely broad-ovate, the margins erose and occasionally with minute teeth, green or pale and thin in texture, abaxially juxtaposed, encircling the stem or a little separated, and with a few marginal hairs. Racemes 5-20 cm long, with 2-5 flowers of even age. Peduncle 1-1.5 mm wide, with the pulvinus not or scarcely distinguishable, with flowers in the top 1-2 cm, terete and often smooth in the lower part, and striate and tending to flatten near the flowers, glabrous except for antrorse hairs near the flowers. Bracts broadly ovate, 2-5 mm long. Flowers reddish purple, 10-15 mm long, on pubescent pedicels c. $3 \mathrm{~mm}$ long. Hypanthium broadly expanded above and narrow below, narrower and fluted in the upper part under the fruiting calyx, the bracteoles broad and large. Calyx with the tube c. $2.5 \mathrm{~mm}$ long, much expanded or inflated, rather obliquely, above the hypanthium, glabrous except for a few very fine hairs on the lobes, the lobes broad-based and deltoid, acuminate or with long-acuminate or acute tips, longer than the tube, the upper often somewhat broader and shorter with their tips recurved, the sinuses very broad but tending to be narrow at the base. Standard $12-15 \mathrm{~mm}$ long and $10-20 \mathrm{~mm}$ broad, almost truncate above a very short broad tapered claw, with two somewhat raised areas or folds near the base. Wings (Fig. 4) 8-10 mm long, almost deltoid, with a deep fold in the central region beyond the claw, the apex narrow and very shortly and rather obliquely obtuse (broader below), the claw very short, broad and curved, the auricle very large, rounded, curved back and folded. Keel 9-10 $\mathrm{mm}$ long and 4-5 mm deep, with the apex projecting upward, narrow but a little inflated and acute, almost spiral from a strong twist near the centre of the keel, with the upper margin distorted by the twist near the apex, deeply downcurved in front of auricles that are large, rounded, long and directed backward, and with the pockets large, the claw rather long with the broad upper part tapering strongly. Ovary c. $6 \mathrm{~mm}$ long, obliquely oblong or broader towards the apex below the oblique very broad style-base, pubescent, obliquely contracted at the base. Ovules numerous but many aborted. Stipe $0.5-1 \mathrm{~mm}$ long, broad, glabrous. Style (Fig. 6) with a broad thin-textured base, very shortly tapered to a narrow unthickened section, the upper $2 / 3$ shallowly curved, pale and stiffened, twisted, often somewhat expanded and tapered only near the narrow straight tip, a long ( $2 \mathrm{~mm}$ or more) narrow ridge of hairs extending down the style from the tip, the beard absent. Fruit 15-25 mm long and 8-10 mm wide, ovoid-oblong, curved, inflated either side of a variably intruded suture so that sometimes dorsiventrally compressed, very shortly tapering at the base to a minute stipe and, at the apex, shortly tapered to a short, narrow, upturned beak, bearing the c. $8-9 \mathrm{~mm}$ recurved and twisted style or its remains, erect, perhaps sometimes pendulous, at maturity, dehiscing both sides of the tip, with a short spreading pubescence, the texture firm and stiff, the surface with a slightly raised reticulation, the veins at $90^{\circ}$ or a little less, the tissue deep, deepest and sometimes folded in the loculus in the centre, closing the loculus. 
Along the upper Murray River valley in Victoria and New South Wales. On flat grassland and in heavy red soil, often on roadsides, especially in table-drains. Fig. 25.

Selected SPECIMENS (from 14 examined): New South WALEs: near Jerilderie, Phillips, 22 Sep 1961 (CANB, NSW); 4 miles [6 km] from Jerilderie, on South Coree road, D'Arnay 382, 4 Oct 1965 (CANB, NSW). VICTORIA: Kerang, Morris 1408, 21 Sep 1925 (NSW); Dingee-Rochester roadside reserve, Beauglehole 82545, 23 Nov 1985 (MEL); Dingee, Wilkinson, 5 Oct 1963 (BRI, CBG, K, MEL, NSW).

75. S. swainsonioides (Benth.) A. Lee ex J. Black

(J.M. Black 1948: 470)

BAsIONYM: Cyclogyne swainsonioides Benth. (Bentham in T.L. Mitchell 1848: 397). Type: Queensland on downs, subtropical New Holland, T.L. Mitchell 482 (463), herb. Benth., Dec. 10. 1846; holo K.

S. drummondii Benth. (G. Bentham 1864: 220). TYPE: herb. Benth., labelled 'from Swan River seeds, Hort. 1842'; holo K.

S. procumbens var. ? minor Benth. (G. Bentham 1864: 220). TYPE: VICTORIA: Wimmera, Dallachy, 18 Sep 1862; K, MEL, NSW.

S. oncinotropis F. Muell. (F. Mueller 1884: 45). TYPE: Victoria: Wimmera, Dallachy, 18 Sep 1862; lecto (fide Lee 1948: 223) MEL; iso K, NSW.

A spreading ascending perennial, often $0.5 \mathrm{~m}$, occasionally $1 \mathrm{~m}$, high, with a number of stems, often much-branched at the base and sometimes below the soil-surface, from the top of a taproot. Stems mostly $2-4 \mathrm{~mm}$ wide but occasionally as wide as 10 $\mathrm{mm}$, terete, sometimes finely ribbed, or somewhat angled or even flattened below the nodes, with dense to sparse spreading or antrorsely curved fine terete fine-pointed tapering hairs c. $0.5 \mathrm{~mm}$ long and basifixed with the base rather tuberculate. Leaves 3$12 \mathrm{~cm}$ or more in length, with 11-21 leaflets above an extended petiole, the leaflets broadly or narrowly obovate or elliptic, occasionally lanceolate, densely or sparsely pubescent with curved hairs, the pubescence usually absent from the upper surface, the lateral leaflets 5-20 mm long and 4-6 mm wide, the terminal irregular, often but not invariably a little longer than the short upper laterals, the leaflet-apex acute or obtuse, very occasionally retuse, with a small recurved point. Stipules to $15 \mathrm{~mm}$ long, usually obliquely deltoid with an acuminate apex, the margins somewhat irregular, green, occasionally abaxially close but usually well-separated there, and with a variable pubescence on both surfaces. Racemes usually from 10 to more than $30 \mathrm{~cm}$ long, with 6-15 flowers of somewhat uneven age. Peduncle 1-c. $5 \mathrm{~mm}$ wide, with the pulvinus not distinguishable, with flowers usually in the top $1 / 3$ but occasionally over more than $1 / 2$ its length, often conspicuously ribbed and somewhat flattened near the flowers, usually glabrous, at least in the lower part. Bracts broadly ovate, often long-acuminate, often c. $4 \mathrm{~mm}$ long. Flowers purple, of variable size, usually 8c. $15 \mathrm{~mm}$ long, on pubescent pedicels c. $5 \mathrm{~mm}$ long. Hypanthium narrow and expanding at the top, tending to contract at the apex under the fruiting calyx, the bracteoles broad and often large. Calyx with the tube $2-2.5 \mathrm{~mm}$ long, inflated rather obliquely above the hypanthium, often almost glabrous, the lobes long-acuminate deltoid, longer than the tube, the upper often a little broader and shorter with their tips tending to recurve, the sinuses narrow-based but sometimes, not always, very broad above. Standard (Fig. 3) 6-16 mm long and 9-22 mm wide, tapering or suddenly contracted to a very short, broad, tapering claw, with two, sometimes obscure or absent, angled folds towards the base. Wings 9-15 mm long, oblong-deltoid, with a long deep fold, the apex shallowly obtuse, rounded and distorted by the fold, the claw rather short, 
tapering to a slender base, and curved, the auricle very large, rounded-deltoid and curved back and folded. Keel (Fig. 5) 8-12 mm long and c. $3 \mathrm{~mm}$ deep, with the apex long, slender, acute and a little swollen, projecting upward before becoming strongly recurved, usually strongly twisted so the tip may be variously directed, with the upper margin downcurved strongly from the deep broadly rounded auricles before rising and strongly curving in the apical half, and with the pockets very large, the claw short and straight. Ovary 5-8 mm long, oblong-elliptic, somewhat curved, densely pubescent, with the apex rather obliquely tapering to the style-base, more suddenly and obliquely tapering to the base. Ovules numerous. Stipe $0.5 \mathrm{~mm}$ long, very broad, glabrous. Style slender, variably and scarcely enlarged at the base that is flattened but not stiffened, the lower c. $3 / 4$ thin in texture, not flattened beyond the base and slightly tapered until very slender, the upper c. $1 / 4$ slightly stiffened and pale and laterally flattened and somewhat flattened under the beard, all curved rather unevenly but so as to form a circle or more, twisted, the tip variously incurved or inflexed, a line of fine hairs extending from close behind the tip, often reduced to a few hairs or absent, the beard short antrorse and limited to a short area behind and on the tip. Fruit 15-35 mm long and 5-8 $\mathrm{mm}$ wide, irregularly elliptic-oblong, curved, inflated, the suture variably intruded, somewhat dorsiventrally compressed, shortly tapered at the base to a minute stipe and at the apex to an upturned beak bearing the variously disposed style 10-20 mm long, or its remains, erect at maturity, dehiscent at the suture and also at the tip on the other side, with a short spreading pubescence, the texture firm and stiff, the surface with a somewhat raised reticulation, the veins $60^{\circ}-$ $90^{\circ}$, the tissue well-developed in the centre and often closing the loculus.

Widespread in inland New South Wales, south-eastern Queensland and northern Victoria, and in north-eastern South Australia with an isolated occurrence in the north-west. In heavy red or black soils, on plains. Fig. 25.

Selected specimens (from c. 340 examined): South Australia: near Old Moolawatana Station, Symon 5950, 22 Aug 1968 (AD, CANB). QueENSLAND: on the Bedourie road, 6.6 miles [10.5 km] $S$ of the Dawson Highway, Speck 1835, 14 Oct 1963 (BRI, CANB, K, NSW). New South Wales: $45 \mathrm{~km}$ from Broken Hill on Menindee road, Corrick 7345, 30 Aug 1981 (AD, MEL); 6 miles [10 km] SE of Dubbo on Mitchell Highway to Wellington, Coveny 2504, 27 Sep 1969 (K, NSW, NT). VICTORIA: Mt Jeffcott Flora Reserve, 17 km ENE of Donald P.O., Beauglehole 65191, 23 Oct 1979 (MEL).

\section{S. procumbens (F. Muell.) F. Muell.}

\section{(F. Mueller 1859a: 76)}

BAsionym: Cyclogyne procumbens F. Muell. (F. Mueller 1852: 393). TYPE: SOUTH AusTRALIA: Broughton River, F. Mueller; holo MEL.

S. violacea Henderson \& A. Henderson (E.G. \& A. Henderson 1864: t. 69). TYPE: the plate drawn from a specimen cultivated from Australian seed.

S. procumbens var. parvifolia J. Black (J.M. Black 1924a: 319). TYPE: SOUTH AUSTRALIA: Bordertown, Turner, 10 Oct 1911; lecto (fide Lee 1948: 226) AD.

A spreading or ascending perennial, often to $0.5 \mathrm{~m}$ high, with complex branching from a stock, often with the lower part of the branches below the soil-surface. Stems $1.5-5 \mathrm{~mm}$ wide, terete and rather striate, with sparse, minute, blunt or tapered, flat or turgid, appressed, basifixed or subbasifixed hairs, or glabrous. Leaves 5-15 cm long, with 15-25 leaflets above an extended, often much extended, petiole, the leaflets linear to obovoid, glabrous or with a few to numerous hairs usually confined to the lower surface, the lateral leaflets $5-25 \mathrm{~mm}$ long and 1 to more than $5 \mathrm{~mm}$ wide, the 
terminal irregular but often somewhat longer than the short upper laterals, the leaflet-apex usually rounded or retuse with a small recurved point. Stipules usually $2-7$ $\mathrm{mm}$ long, deltoid, very broad-based, the margins irregular and often toothed, usually green, juxtaposed at the back or separated with a short ridge or line of hairs between, and glabrous, pubescent only on the edge or with a few hairs on the outer apex. Racemes very variable, $5-30 \mathrm{~cm}$ long, with $2-6(-$ c. 12) flowers of almost even age. Peduncle $1.5-3 \mathrm{~mm}$ wide, with the pulvinus not distinguishable, with flowers usually in the upper $1 / 4$ or less, occasionally extending to $c .1 / 2$ the length, somewhat striate, terete or rather flattened near the flowers, almost glabrous or with hairs in the upper part. Bracts ovate or lanceolate, 3-5 mm long. Flowers purple, often with a yellow keel-tip, occasionally mauve or pink, $10-20 \mathrm{~mm}$ long, on pubescent pedicels $3-5 \mathrm{~mm}$ long. Hypanthium narrow-based and fluted and expanded above, contracting near the apex under the fruiting calyx, the bracteoles broad and rather large. Calyx with the tube c. $2.5 \mathrm{~mm}$ long, a little and obliquely expanded or inflated above the hypanthium, glabrous or with some hairs on the lobes, the lobes deltoid with acuminate tips of variable length, the upper usually much shorter and broader than the lower, with recurved tips, the upper equal to or shorter than the tube, the lower often longer, the sinuses often broad, sometimes narrow, especially at the base. Standard 12-18 mm long and usually 20-25 mm wide, contracted or incurving to a minute claw, with two folds near the base. Wings 10-15 mm long, irregularly oblong, with a shallow fold in the upper central part, the apex obliquely and shallowly obtuse (the lower edge longer), the claw short, rather broad and a little tapered, strongly curved, the auricle large, long, rounded, raised and then strongly recurved. Keel c. 12-15 mm long (horizontally) and 6-7 $\mathrm{mm}$ deep, with a long upwardly extended recurving apical section that is tapered to a narrow apex, a little swollen behind (below) this and coiled, twisted and folded so as to loop back on itself and usually ultimately extend forward, with the upper margin curved downward from the broad, shortly backwardly directed auricles, and then upward, being distorted by the twisted coil, and with the pockets large and distinct, the claw short, rather broad, slightly tapered and straight. Ovary 6-8 mm long, elliptic-oblong, glabrous or with a short close pubescence over much or part, with the apex tapering and upcurved, suddenly and obliquely a little contracted at the base. Ovules numerous. Stipe to c. $1 \mathrm{~mm}$ long, broad, glabrous. Style slender, tapering from the base to a very slender part well above the centre and then broadening for the apical c. $1 / 4$, where flattened, somewhat laterally flattened throughout but unthickened and especially thin below the apical part, the curvature less near the apex and base, forming a twisted irregularly directed coil in the central area, with the tip slender and somewhat incurved or slightly inflexed, the beard dense, rather short, antrorse, restricted to the spirally twisted top $1 / 4$ or $1 / 3$ and the tip. Fruit $20-40 \mathrm{~mm}$ long and c. $10 \mathrm{~mm}$ wide, narrowelliptic to oblong, often curved, inflated, with the suture intruded, often broadly, somewhat dorsiventrally compressed, narrowing and stipe-like at the base above a very short stipe and, behind the apex, tapering suddenly behind an acute, often curved, narrow beak occasionally bearing the remains of the c. $30 \mathrm{~mm}$ style, raised to erect at maturity, dehiscent along the upper suture and near the tip on the other side, glabrous or with a sparse appressed pubescence, the texture very stiff (almost woody), the surface with obscure fine venation at c. $90^{\circ}$, the tissue well-developed, especially in the centre, and closing the loculus.

Widespread in inland New South Wales, Victoria and southern Queensland, and in south-eastern South Australia. Usually in heavy soil prone to waterlogging. Fig. 25.

SELECTED SPECIMENS (from c. 255 examined): SOUTH Australia: between Wirrabarra \& Yandiah, Rowe 2483, Aug-Sep 1969 (AD). QueENSLAND: Springmount, c. 5 miles $[8 \mathrm{kml} \mathrm{S}$ of Westmar, Pedley 493, 6 Oct 1959 (BRI, K). New SOutH WaLEs: Darling River, Dallachy \& Goodwin (BM, K, MEL); Lockhart-Urana road, Constable 5186, 21 Oct 1964 (K, MEL, NSW, NT). Victoria: 1 km S 
of Wunghnu, between Goulburn Valley Highway \& railway line, Muir 6021, 21 Sep 1978 (AD, MEL, NSW).

\section{Group 13}

1 Hypanthium strongly twisted; keel with a retracted tip 78. S. murrayana

$1^{*}$ Hypanthium not strongly twisted and if slightly twisted then the keel-tip not retracted

2 Flowers purple or pink; stipules various but never large, pubescent and broad with broad teeth

3 Stem-hairs c. $1 \mathrm{~mm}$ long and loosely appressed or with the ends raised

79. S. fissimontana

3* Stem-hairs $0.5 \mathrm{~mm}$ long or shorter, and mostly closely appressed

4 Leaflet-apex not glandular

5 Peduncle $0.5 \mathrm{~mm}$ or more in width; flowers 5-15 mm long and opening normally

6 Fruit-shape various but fruit more than 4 times as long as wide, the surface smooth or if with a raised reticulation then the veins at less than $90^{\circ}$, the suture strongly indented; vegetative parts not conspicuously dark when dry.

7 Flowers usually more than $10 \mathrm{~mm}$ long but if smaller then the pedicels $3-5 \mathrm{~mm}$ long; style c. (4-)6-8 mm long, the tip without a tuft

77. S. purpurea

$7^{*}$ Flowers 5-8 mm long on pedicels of 1-3 mm; style usually $4 \mathrm{~mm}$ long, the tip with a minute tuft

81. S. microcalyx

$6^{*}$ Fruit almost oblong with the width more than $1 / 3$ the length, with a strongly raised venation at $90^{\circ}$; the suture scarcely indented; vegetative parts conspicuously dark in dried specimens

80. S. fuscoviridis

$5^{*}$ Peduncle very slender, often less than $0.5 \mathrm{~mm}$ wide; flowers 4-5 $\mathrm{mm}$ long and often failing to open normally

82. S. minutiflora

$4^{*}$ Leaflets with a conspicuous terminal gland

83. S. adenophylla

$2^{*}$ Flowers usually light red, orange or brown; stipules large, densely pubescent, very broad and with broad teeth

8 Flowers (7-)10-15 mm long; keel conspicuously twisted; style-tip without an extension

84. S. stipularis

8* Flowers 8-10 mm long; keel scarcely, if at all, twisted; style-tip with a slender divergent extension.

85. S. eremaea

\section{S. purpurea (A. Lee) J. Thompson}

\section{(J. Thompson 1990: 4)}

BASIONYM: S. stipularis var. purpurea A. Lee (A.T. Lee 1948: 213)

Trre: SOUTH Australia: S.D.E. Camp 41, 28 July 1935; holo AD.

S. stipularis var. longialata A. Lee, loc. cit. TYPE: NEW SouTH WALES: Far North Western Plains: Bulloo Overflow N.C.W. Beadle 613, 12 Aug 1941; holo NSW.

An erect or spreading annual or perennial reaching c. $50 \mathrm{~cm}$ high, with few to numerous stems from the top of a taproot, or with a stout complex stock, the stem-bases 
often below the soil-surface. Stems 1-5 mm, or even more, in width, terete or somewhat flattened or angled near the nodes, variably, often densely, pubescent, the hairs usually $0.5 \mathrm{~mm}$ long, elliptic with the ends rather blunt to narrowly elliptic with narrowly pointed ends, mostly closely appressed, turgid or occasionally flat and medifixed, often asymmetrically. Leaves mostly 3-12 cm long, with 3-11 leaflets above a long petiole, the leaflets variable in size and shape but mostly linear or elliptic, the pubescence on both surfaces but often sparse, the lateral leaflets mostly 10-30 mm long and 1-5 mm wide, the terminal usually much longer than the upper laterals, the leaflet-apex very variable, acute and with a distinct recurved point to expanded and emarginate with a central point. Stipules from minute to c. $10 \mathrm{~mm}$ long, narrow, lanceolate to acuminate-deltoid, without lateral teeth, green, not forming an abaxial ridge but sometimes separated there by an abaxial line of hairs, and usually with a sparse pubescence on both surfaces. Racemes $5-30 \mathrm{~cm}$ long, with $3-\mathrm{c}$. 20 flowers of almost even age. Peduncle $0.5-4 \mathrm{~mm}$ wide, with the pulvinus usually conspicuous, densely pubescent and often dark, with flowers occupying less than, often much less than, $1 / 2$, smooth to conspicuously ribbed, with short appressed hairs, sometimes dark near the apex. Bracts ovate to ovate-lanceolate, 1-3 mm long. Flowers purple, usually 12-14 mm long, rarely 6-8 $\mathrm{mm}$, on, often dark, pubescent, pedicels c. 3-5 mm long. Hypanthium narrow and rather fluted, very occasionally with a slight twist, scarcely contracting at the apex under the fruiting calyx, the bracteoles variable and small. Calyx with the tube $1.5-2.5 \mathrm{~mm}$ long, mostly expanding gradually above the hypanthium, with an appressed, sometimes dark, pubescence, the lobes deltoid and much shorter than the tube to acuminate-deltoid and approximately equal to it or even a little longer, the upper lobes a little shorter than the lower, the sinuses usually rather broad. Standard (6-)10-15 mm long and usually as wide, tapering to a short tapered claw, with two flaps, from infolds of the claw, near the base. Wings (5-)10$15 \mathrm{~mm}$ long, curved-obovoid, the apex rather obliquely and shortly obtuse, the claw not long, rather broad and tapered and somewhat curved, the auricle rather large, rounded and recurved, and somewhat folded. Keel (5-)10-13 mm long and (2-)3-5 $\mathrm{mm}$ deep, with the apex obtuse and rounded, often curving upward and often, perhaps as the flower ages, with a lateral twist, the upper margin sometimes almost straight, but usually somewhat to very much down-curved behind the apex and raised to the rounded-truncate deep auricles, and with large but often obscure pockets, the claw not long, tapered. Ovary (2-)c. $6 \mathrm{~mm}$ long, elliptic-oblong, with a close appressed pubescence longer near the suture, tapering rather abruptly, or even expanding, to the broad style-base and tapering, rather obliquely, at the base. Ovules numerous. Stipe c. $0.5 \mathrm{~mm}$ long, broad, glabrous. Style (Fig. 6) rather slender and long-tapering, laterally compressed, and, above the base, very stiff and pale, curved evenly, or more strongly at the base and apex, often tending to twist slightly, the upper part tapering to a fine unthickened or less thickened tip that is straight or irregularly disposed, the beard usually over the whole length but often sparse in the lower part or absent there. Fruit very variable, from $10-60 \mathrm{~mm}$ long and (2-)4-5 mm wide, fusiform-elliptic, somewhat curved, with both ends usually tapering but occasionally obtuse, inflated with the suture deeply indented, with a short stipe and somewhat beaked at the apex and bearing the (4-)6-8 $\mathrm{mm}$ recurved style or its remains, rather pendulous or raised to near the horizontal at maturity, tardily dehiscent along the suture, with short appressed hairs, the texture stiffly leathery, the veins fine but obvious to conspicuously raised, at $30^{\circ}-60^{\circ}$, the tissue deep in the centre, absent from the ends, sometimes closing the loculus.

Widespread in inland Western Australia and South Australia, and in adjacent parts of the Northern Territory, Queensland, far western New South Wales and northwestern Victoria. In low-lying areas or on dunes, and usually associated with lakemargins, and often with salt and/or gypsum. Fig. 26. 
Selected SPECimEns (from c. 160 examined): Western Australia: Lake Carnegie, Speck 1267, 20 Aug 1958 (AD, CANB, NSW). South Australia: Evelyn Downs, Ising 55, Oct 1950 (AD, MEL, NSW, PERTH). QueENSLAND: $50 \mathrm{~km}$ N of Birdsville, Pedley, 29 Oct 1977 (AD, BRI, CANB, K, NSW). New South Wales: Lake Cawndilla, S of Menindee, Burbidge 6629, 22 July 1960 (CANB, NSW). VICTORIA: Raak Plain, Browne, 30 Sep 1980 (MEL).

\section{S. murrayana Wawra}

(H.R. von F. Wawra 1881: 69)

TYPE: Australien am Murray [River], Coll. 1 (Weltreise) 429b; holo ?G, n.v.

S. morrisiana J. Black (J.M. Black 1926: 283). TYPE: SOUTH Australia: Boolcoomatta Station, A. Morris 1448, 22 Aug 1926; holo AD; iso AD, K, MEL, NSW.

S. murrayana subsp. eciliata A. Lee (A.T. Lee 1948: 221). TYPE: NeW SOUTH WALEs: North Western Slopes: near Baradine, J. Witter NSW 657, Nov 1900; holo NSW.

An erect, ascending or occasionally prostrate perennial, usually less than $25 \mathrm{~cm}$ high, with many stems from a, probably often complex, underground system, with much branching below the soil-surface. Stems $1-2(-2.5) \mathrm{mm}$ wide, terete or somewhat angled below the nodes, rather densely pubescent, the hairs c. $0.5 \mathrm{~mm}$ long, elliptictrapezoid with the ends much tapered and acute, appressed, very flat and medifixed. Leaves usually 5-10 cm long, with 3-11 leaflets above a long, often very long, petiole, the leaflets very narrow, linear-lanceolate to elliptic, the appressed pubescence sparse on or absent from the upper surface, the lateral leaflets 5-30 mm long and 1-2 mm wide, the upper often longest, the terminal usually conspicuously longer than the laterals, the leaflet-apex narrowly acute with a short recurved point. Stipules 1 to more than $5 \mathrm{~mm}$ long, deltoid to almost linear above a short wide base, variably acuminate, sometimes with broad lateral teeth, green, not forming an abaxial ridge and with loose hairs on both surfaces. Racemes usually $10-25 \mathrm{~cm}$ long, with 3-9 flowers of scarcely uneven age. Peduncle $0.5-2 \mathrm{~mm}$ wide, with the pulvinus usually obvious and sometimes dark and pubescent, with flowers occupying the upper 1/4 or less, terete or somewhat ridged or angled, with a short appressed pubescence often dark in the upper part. Bracts ovate, c. $2 \mathrm{~mm}$ long. Flowers pink or purple, c. $10 \mathrm{~mm}$ long on dark-pubescent pedicels 3-5 mm long. Hypanthium short, fluted, rather narrow and strongly twisted, not contracting at the apex under the fruiting calyx, the bracteoles very small. Calyx with the tube c. $2.5 \mathrm{~mm}$ long, broad-based and obliquely expanded above the hypanthium, with an appressed, usually dark, pubescence, the lobes narrowly deltoid, acuminate and shorter than the tube, the lower sometimes longer, the sinuses rather broad and rounded. Standard $10 \mathrm{~mm}$ long and $7-8 \mathrm{~mm}$ wide, tapering to a tapered claw, usually with two long well-spaced, rather asymmetric, high folds at the base. Wings 8-10 mm long, obovoid, shortly and rather obliquely obtuse at the broad apex, the claw long, curved and much tapered, the auricle long, round, often conspicuously recurved, twisted and often rather thickened and/or pubescent. Keel 7-9 $\mathrm{mm}$ long and 2-3 mm deep, very obtuse with the beak-like tip somewhat behind the end, usually with a strong twist towards, but not close to, the apex, with the upper margin curved downward behind the tip and raised towards the deep, often rounded or almost truncate, auricles, and with the pockets distinct to obscure, the claw long, sometimes tapered in the upper part. Ovary c. $4 \mathrm{~mm}$ long, ovoid-oblong, closely pubescent, untapered at the apex behind the broad style-base and only a little and obliquely tapered at the base. Ovules numerous. Stipe c. $0.5 \mathrm{~mm}$ long, rather broad, glabrous. Style (Fig. 6) much expanded at the base then contracting with an even taper to behind the rather stout tip, strongly laterally compressed, pale, stiffened over the whole length, much curved especially near the base and 
strongly twisted above the base, towards the tip the area below the beard is invariably flattened in the other dimension with the tip unthickened and usually incurved, the beard often dense and usually over the whole length but sometimes restricted to the upper part. Fruit $20-$ c. $65 \mathrm{~mm}$ long and $4-7 \mathrm{~mm}$ wide, narrowly elliptic, curved, inflated either side of a variably intruded suture so that sometimes dorsiventrally compressed, at the base tapering to a narrow stipe-like section above the c. $0.5 \mathrm{~mm}$ stipe, and, at the apex, gradually tapering to or shortly rounded behind a minute slightly upturned beak bearing the c. $4 \mathrm{~mm}$ twisted style or its remains, probably raised at maturity, dehiscent along the suture, with an even but sparse appressed pubescence, the texture thin and stiffly leathery, the surface smooth with fine veins at $30^{\circ}-45^{\circ}$, the tissue deep, perhaps usually closing the loculus.

On the western slopes and plains of New South Wales and in equivalent areas of northern and western Victoria and southern Queensland, and with an outlying population in South Australia west of Broken Hill. In heavy soils, often in depressions; frequently associated with Maireana spp. Fig. 26.

Selected SPECimens (from c. 60 examined): QueEnsland: S of Surat, $14 \mathrm{~km}$ on St George road, Jones 195, 10 Sep 1961 (BRI). New South Wales: Lake Goran, E of Tambar Springs, Briggs 2269, 29 Sep 1968 (K, NSW, NT); 11 miles [17 km] SW of Gulargambone, Biddiscombe 252, 9 Sep 1953 (CANB, NSW); 42 miles [65 km] from Hay on Sturt Highway towards Narrandera, Phillips 040363, 7 Sep 1961 (CBG). Victoria: Two Tree Swamp, E of Lake Cooper, Corrick, 9 Sep 1984 (MEL, NSW).

\section{S. fissimontana J. Black}

(J.M. Black 1927: 381)

Type: New South Wales: Northern Far Western Plains: near Broken Hill, A. Morris 1346, 5 Sep 1925; lecto (fide Lee 1948: 208) AD; iso AD, NSW.

S. fissimontana var. coarctata J. Black (J.M. Black 1928: 225). TYPE: SOUTH AusTRALIA: Hawker, Flinders Range, J.M. Black, 18 Oct 1917; lecto (fide Lee 1948: 208) AD; iso K, NSW (fragment).

An erect or ascending, probably perennial, plant to c. $50 \mathrm{~cm}$ high, with a number of stems, often with their bases below the soil-surface, from a slender taproot. Stems 1$2.5 \mathrm{~mm}$ wide, terete or obscurely ribbed, the hairs usually dense, c. $1 \mathrm{~mm}$ long, narrowly elliptic with both ends long-tapering to fine points, loosely appressed or with the ends curved or raised, terete or flattened, medifixed, often asymmetrically, and often raised above the stem at the point of attachment. Leaves mostly 4-6 cm long, with 7-13 leaflets above an extended petiole, the leaflets usually narrowly elliptic, occasionally broader, with a dense appressed pubescence on both surfaces, the lateral leaflets 5-15 $\mathrm{mm}$ long and 1-3 mm wide, the terminal usually somewhat longer, the leaflet-apex usually acute with a recurved point, occasionally obtuse or retuse. Stipules c. $5 \mathrm{~mm}$ long, mostly narrowly deltoid with a variably tapered upper part, the base sometimes somewhat extended, green, usually well separated abaxially and with scattered hairs on both surfaces. Racemes usually $10-30 \mathrm{~cm}$ long, with 3-11 flowers of scarcely uneven age. Peduncle $0.5-1.5(-2) \mathrm{mm}$ wide, with the pulvinus conspicuous and often dark, with the flowers usually confined to the upper $1 / 3$ or less, ribbed, with sparse, irregularly appressed hairs that are sometimes dark on the upper part. Bracts ovate-lanceolate, 1-2 mm long. Flowers pink to dark purplish red, 8-10 mm long, on often dark-pubescent pedicels c. $3 \mathrm{~mm}$ long. Hypanthium slender and fluted but not contracted under the fruiting calyx, the bracteoles minute. Calyx with the tube c. $3 \mathrm{~mm}$ long, conspicuously rounded, often unevenly, above the hypanthium, with an appressed dark pubescence, the lobes deltoid-acuminate, often very 
narrow above the base, equal to or a little shorter than the tube and not very dissimilar, the sinuses broad and rounded. Standard c. $10 \mathrm{~mm}$ long and 10-13 mm wide, rather abruptly tapered to a short, tapered claw, with long, slender thickened ridges at the base. Wings 8-12 mm long, rhomboid, the apex obliquely almost truncate (with the lower part longest), the claw long, slender, a little tapered and curved, the auricle large rounded-deltoid, and tending to curve backward, with a central fold. Keel (Fig. 5) 8-11 mm long and c. $4 \mathrm{~mm}$ deep, with the apex narrow, obtuse but with the tip tending to curve upward, and with a strong lateral twist or strong fold well behind the apex, with the upper margin at first somewhat raised in the centre but soon distorted and the auricles not deep, rounded and backwardly directed, with the pockets large, the claw rather long and strongly tapered. Ovary $3-5 \mathrm{~mm}$ long, oblongelliptic, curved, with a dense appressed pubescence (sometimes some hairs raised near the base), not tapered at the apex behind a very broad style-base but somewhat and obliquely tapered at the base. Ovules numerous. Stipe c. $1 \mathrm{~mm}$ long, broad, glabrous. Style very broad-based and much laterally compressed, stiffened, tapering rather evenly although less in the upper part where becoming flattened in the other dimension under the beard, with a strong lateral twist toward the base and an even slight curve above, the apex usually firm, often rounded, with a minute curved extension, the beard only in the upper $2 / 3$ or less. Fruit $15-20 \mathrm{~mm}$ long and $4-5(-6) \mathrm{mm}$ wide, elliptic or a little wider above the middle, curved, inflated with, at maturity, the suture very narrowly intruded, tapering at the base to a short, c. $0.5 \mathrm{~mm}$, slender stipe, and, more gradually, at the apex to a short straight beak bearing the c. $7 \mathrm{~mm}$ style, or its remains, that is looped towards the base and usually reflexed, erect at maturity, the dehiscence not seen, with scattered loosely appressed hairs, the texture stiffly leathery, the surface smooth, with fine veins at $30^{\circ}-45^{\circ}$, the tissue short, even and contained within the closed loculus.

From far western New South Wales to the northern Flinders Ranges and northward in South Australia. In stony, sandy or clay-loam soils, on plain or hill-slopes. Fig. 26.

Selected SPecimens (from c. 120 examined): South Australia: Blinman, Blake 16912, 31 Aug 1946 (AD, BRI, NSW); $0.5 \mathrm{~km}$ NNW of Waukaringa, Sikkes 1255 \& Ollerenshaw, 29 Sep 1973 (CBG, K). New South Wales: 'Horton Park', 12 miles [20 km] NE of Tibooburra, Wood, Aug 1967 (NSW); Silverton, Vickery \& Pidgeon, 24 Aug 1939 (BRI, NSW 605); Thompsons Siding, Morris 1450, 12 Sep 1926 (AD, K, NSW).

\section{S. fuscoviridis J. Thompson, sp. nov.}

Herba prostrata vel erecta perennis usque ad c. $25 \mathrm{~cm}$ alta. Foliola c. 7-9 elliptica vel oblanceolata. Racemi $10-25 \mathrm{~cm}$ longi floribus 5-7 mm longis. Calyx lobis tubo valde brevioribus. Vexillum versus basim plicis duobus. Carina acuta retrocurvata. Stylus valde complanatus incrassatus apice incurvato vel valde inflexo. Fructus $10-14 \mathrm{~mm}$ longus 4-5 mm latus suboblongus.

Type: South Australia: $35 \mathrm{~km}$ NE of Yunta towards Cockburn, A.J.A. Sikkes $1257 \mathcal{E} P$. Ollerenshaw, 29 Sep 1973; holo NSW; iso CBG.

A perennial to $c .25 \mathrm{~cm}$ high, with numerous erect or prostrate stems, often branching below the soil-surface but usually from the top of a taproot; the vegetative parts often dark-coloured in dried specimens. Stems mostly 1.5-2.5 mm wide, terete or somewhat ribbed or angled below the nodes at least when young, the hairs dense or sparse, often c. $0.5 \mathrm{~mm}$ long, elliptic, pointed at both ends, appressed or occasionally with one or both ends irregularly raised, flat and medifixed, often asymmetrically. Leaves 3-6 cm long, with c. 7-9 leaflets above an extended although variable petiole, the leaflets elliptic to linear or obovate or oblanceolate, with a loosely appressed pubes- 
cence on both surfaces or absent from the upper, the lateral leaflets $10-20 \mathrm{~mm}$ long and 1-3 mm wide, the terminal irregularly developed but often longer than the upper laterals, the leaflet-apex rounded and retuse or occasionally narrow and recurved with a short point. Stipules $2-4 \mathrm{~mm}$ long, deltoid to long-acuminate-deltoid, dark green, not forming an abaxial ridge and densely pubescent on the outer surface, more sparsely on the inner. Racemes 10-25 cm long, with 12-20 flowers of slightly uneven age. Peduncle 1-2 mm wide, usually with the pulvinus obvious, with short close hairs and occasionally dark; with the flowers in the upper $1 / 3$, terete or ribbed, the pubescence appressed with some dark hairs near the flowers. Bracts ovate, c. $1 \mathrm{~mm}$ long. Flowers 5-7 mm long, purple, on densely often dark, pubescent pedicels 1-3 mm long. Hypanthium narrow, somewhat contracted at the apex under the fruiting calyx, the bracteoles small and narrow. Calyx with the tube 1.5-2 mm long, variably obliquely and not strongly exparıding above the hypanthium, with dense, appressed (often rather loosely), mostly dark, hairs, the lobes acuminate deltoid, the upper only slightly broader and shorter, much shorter than the tube, the sinuses broad and rounded. Standard c. $7 \mathrm{~mm}$ long and $6-8 \mathrm{~mm}$ wide, tapering or somewhat contracting above a broad short claw, with angled folds in the lower part. Wings 6-7 mm long, oblong, often narrowly, very shortly and obliquely obtuse with the lower edge longer, the claw not very long but very slender and scarcely tapered, the auricle deep and almost truncate. Keel 5-7 mm long and c. $2 \mathrm{~mm}$ deep, with the apex rather acute and curved upward so the tip is behind the end, and with a slight lateral twist, with the upper margin curved downward, the auricles deep and deltoid or rounded, and with the pockets short and large, the claw rather long, very slender and slightly tapered. Ovary 2-3 mm long, elliptic, often broadly or irregularly, with a dense close pubescence, scarcely tapered or even broader at the apex behind the very broad (sometimes broader than the ovary-apex) style-base, slightly tapered at the base. Ovules numerous. Stipe up to $0.5 \mathrm{~mm}$ long, broad, glabrous. Style very broad-based and tapering rather evenly to the apex, strongly flattened, pale and stiffened from the base, curved downward and then upward to near the vertical, with a strong spiral twist from beyond the base, in the upper part the style somewhat expanded in the other dimension with the extreme tip incurved to much inflexed, the beard sparse in the lower part and dense near the tip. Fruit (one specimen seen) 10-14 mm long and 4-5 mm wide, almost oblong, slightly broader towards the apex, inflated, slightly dorsiventrally compressed, with the suture narrowly and not deeply indented, obtuse at the base above a minute stipe and, at the apex, broadly obtuse in front of the recurved beak-like, sometimes looped, c. $5 \mathrm{~mm}$ style or its erect base, most raised to near or above the horizontal at maturity, dehiscent along the suture, the pubescence short, appressed and rather sparse, the texture very stiff and firm, the surface with strongly raised reticulation, the veins at $c .90^{\circ}$ or a little less, the tissue very deep and sealing the loculus.

Confined to an area north of Adelaide and another west of Broken Hill, both in South Australia.The few field notes indicate a species of arid tussock grassland. Fig. 26.

This species is named for the dark colour of vegetative parts in dried material. From the Latin fuscus, dark, viridis, green.

Selected SPeCimens (from 13 examined): South Australia: $22 \mathrm{~km} \mathrm{~N}$ of Plumbago Homestead, Chinnock 1290, 30 Sep 1973 (AD, NT); Old Boolcoomatta Station, c. $26 \mathrm{~km} \mathrm{~N}$ of Olary, Nash, 12 Oct 1964 (NSW); Waukaringa, Donner 511, 1 Sep 1962 (AD); Goyder Siding to Bowmans R.S., Cooper, Sep 1964 (AD); Yorke Peninsula, Tepper 148 (MEL). 


\section{S. microcalyx J. Black}

(J.M. Black 1924b: 322)

TYPe: South Australia: Tarcoola, E.H. Ising, 21 Sep 1920; holo AD; iso AD, K, MEL, NSW.

A prostrate or low-growing perennial, with numerous stems, often much-branched below the soil-surface, from the top of a stout taproot. Stems $1-1.5(-2) \mathrm{mm}$ wide, smooth and terete except at the nodes, the hairs scattered, $0.5 \mathrm{~mm}$ long or shorter, often elliptic, appressed, flat or turgid and basifixed or subbasifixed to asymmetrically or symmetrically medifixed. Leaves usually $2-6 \mathrm{~cm}$ long, with 5-9 leaflets, variable in turgor, above an extended petiole, the leaflets from broadly obovate or cuneate to narrowly oblong-linear, with an appressed pubescence on both surfaces, dense on the lower, the lower leaflets mostly 3-15 mm long and 1-4 mm wide, the terminal usually much longer than the sometimes smaller upper laterals, the leaflet-apex usually emarginate and often laterally extended but sometimes retuse, truncate or even trilobed, without a point. Stipules 1-5 mm long, obliquely long-deltoid, acuminate, often with members of a pair conspicuously uneven, green, sometimes forming a short abaxial ridge and pubescent on the margins and often the outer surface. Racemes 5$15(-20) \mathrm{cm}$ long, with 5-c. 15 flowers. Peduncle $0.5-2 \mathrm{~mm}$ wide, with the pulvinus often dark and/or pubescent, and with flowers usually confined to the top $1 / 2-1 / 3$ or even less, terete or ribbed at least in the upper part, with scattered short appressed hairs more dense and sometimes dark in the upper part. Bracts ovate, c. $1 \mathrm{~mm}$ long. Flowers purple, 5-8 mm long, on, often dark-pubescent, pedicels 1-3 mm long. Hypanthium short and narrow, somewhat contracting at the apex under the fruiting calyx, the bracteoles minute. Caly $x$ with the tube $1.5-2 \mathrm{~mm}$ long, only slightly and gradually expanded above the hypanthium, with a short, appressed, usually sparse, sometimes dark, pubescence, the lobes deltoid, often acuminate, shorter than the tube, and not very dissimilar, the sinuses broadly rounded. Standard $6-8 \mathrm{~mm}$ long and $5-8 \mathrm{~mm}$ wide, gradually tapering to a short tapered claw, without thickening. Wings 6-8 $\mathrm{mm}$ long, narrowly obovoid or oblong, the apex very shortly obtuse and oblique (the lower edge longer), the claw long, curved and slightly tapered, the auricle long, rather narrow, curved backward and twisted. Keel 6-8 $\mathrm{mm}$ long and 2-2.5 mm deep, with the apex obtuse and somewhat inflated below the tip and twisted behind it, with the upper margin a little raised behind the tip and curved downward only near the rather narrowly rounded-deltoid auricles, and with large pockets, the claw long, slender, straight and without much taper. Ovary c. $4 \mathrm{~mm}$ long, elliptic, curved, with extremely minute appressed hairs over the whole, just the distal part and with somewhat longer hairs along the suture, or glabrous, tapered gradually at the apex to the style-base and suddenly and a little obliquely at the base. Ovules numerous. Stipe less than $0.5 \mathrm{~mm}$ long, broad and glabrous, or absent. Style broad-based, laterally compressed and a little thickened from the base, tapered, sometimes only in the upper half, to a very slightly inturned and occasionally attenuate tip with a minute tuft of hairs there, with a twist near the base, the curvature strong at the base, more slight above, the beard usually along the whole length but variable in amount. Fruit c. 20 $\mathrm{mm}$ long and 3-4 mm wide, very narrowly obovate to elliptic, inflated either side of the deeply and narrowly intruded suture, somewhat tapered at the base with a negligible stipe, and, at the apex, shortly rounded behind, or tapering to, a short, sometimes beaked, apex bearing the remains of a stiff-based c. $4 \mathrm{~mm}$ style that is recurved or looped above its base, becoming erect at maturity, dehiscent at least along the upper suture, with appressed, evenly spaced, short hairs, the texture stiffly leathery, the veins obscure to strongly raised and at c. $45^{\circ}$, the tissue ragged but closing the loculus. 
In an area north of the Eyre Peninsula in South Australia, with an outlier in central Western Australia. Usually on flat, sandy margins of salt lakes, with ephemeral herbs. Fig. 26.

Selected specimens (from 16 examined): Western Australia: $W$ end of Lake Miranda, Toelken 6092, 11 Sep 1979 (AD). South Australia: $20 \mathrm{~km}$ E of Wilgena Station, Weber 2888, 30 Sep 1971 (AD, BRI); Lake Hart, Story 7843, 9 Nov 1979 (AD); Uno Range, W of Lake Gilles, Whibley 7787, 23 Sep 1963 (AD, BRI, CANB, NT).

\section{S. minutiflora A. Lee}

\section{(A.T. Lee 1948: 208)}

TyPe: SOUTH Australia: Mt Lyndhurst, M. Koch 484, Aug 1899; holo NSW.

An often small, perhaps annual, plant reaching $c .15 \mathrm{~cm}$ high, with a number of prostrate or ascending stems arising from the top of a slender taproot. Stems 1-c. 3 $\mathrm{mm}$ wide, terete or somewhat flattened or broadly angled below the node, the hairs often rather spaced but obvious, mostly c. $0.5 \mathrm{~mm}$ long, elliptic and tapering at both ends, appressed, flat or turgid and medifixed, often asymmetrically so. Leaves often 3-5 cm long, with 5-11 leaflets above a rather long petiole, the leaflets in general very narrowly obovate-elliptic, usually appressed-pubescent on both surfaces but often more sparsely above, the laterals 5-15 mm long, the lower usually longer, and 1-2 $\mathrm{mm}$ wide, the terminal sometimes longer, the leaflet-apex narrowly obtuse, pointed, and conspicuously recurved. Stipules minute to c. $5 \mathrm{~mm}$ long, deltoid with variable attenuation above, often with members of a pair conspicuously uneven, green, widely to scarcely spaced at the back, occasionally forming an abaxial ridge and sparsely pubescent on the outer surface, especially near the margin. Racemes 3-8 cm long, with 2-7 flowers of slightly uneven age. Peduncle $0.5 \mathrm{~mm}$ or less in width, with the pulvinus often conspicuous and dark, with the flowers usually in the upper $1 / 3$, obscurely ribbed, with a pubescence of, often spaced, mostly appressed hairs. Bracts ovate to elliptic, acuminate, c. $1 \mathrm{~mm}$ long. Flowers 'pinkish', 4-5 mm long, on darkpubescent pedicels c. $2 \mathrm{~mm}$ long. Hypanthium short and very narrow, contracting at the apex under the fruiting calyx, the bracteoles minute. Calyx with the tube c. $1 \mathrm{~mm}$ long, only gradually expanding above the hypanthium, with a short, loosely appressed, dense, dark pubescence, the lobes deltoid, acuminate, approximately equal to the tube, and not very dissimilar, the sinuses broadly rounded. Standard c. $4 \mathrm{~mm}$ long and as wide, often crumpled and shortly and tardily raised or not raised, i.e. the flower is cleistogamous, contracting at the base to a short tapered claw, with some fine vertical lines of thickening. Wings $4-4.5 \mathrm{~mm}$ long, obovate-oblong, the apex very shortly obtuse, the claw long, slender and curved, and long-tapering, the auricle rather large, raised and rounded. Keel c. 4-5 mm long and 1-1.5 $\mathrm{mm}$ deep, with the apex tapering and acute, often obscurely twisted sideways, with the upper margin straight or very slightly raised in the centre, and with distinct pockets, the auricles deeply truncate, the claw rather long and tapered. Ovary $1.5-2 \mathrm{~mm}$ long, broadly elliptic, and slightly curved, with a short appressed pubescence, tapered at the apex behind a rather broad style-base and, somewhat obliquely, at the base. Ovules numerous. Stipe c. $0.5 \mathrm{~mm}$ long, broad, glabrous. Style relatively stout, broad-based and strongly and evenly tapered, somewhat laterally compressed, thickened, at least for the most part, the apex strongly incurved, evenly and not strongly curved below, sometimes with a slight twist below the centre, the beard short and sometimes dense, in the upper $2 / 3$. Fruit $15-20 \mathrm{~mm}$ long and $2-4 \mathrm{~mm}$ wide, elliptic, dorsiventrally compressed with a broad indentation, or inflated either side of a deeply intruded suture, tapering at the base to a very short stipe and somewhat variously tapered at 
the apex to a, usually rather upturned, short beak bearing the remains of the recurved c. $1.5 \mathrm{~mm}$ style, becoming almost erect at maturity, dehiscent along the suture, with scattered appressed hairs, the texture thinly leathery, the surface with indistinct raised veins at c. $45^{\circ}$, the tissue short and even, not closing the loculus.

In eremean central eastern South Australia. On stony plain country. Fig. 26.

SPECIMENS EXAMINED: SOUTH AustRALIA: Curdimurka Railway Station, Weber 8640, 28 Feb 1984 (AD); c. $10 \mathrm{~km} \mathrm{~S}$ of Curdimurka, Weber 5746, 3 Oct 1978 (AD); c. $30 \mathrm{~km} \mathrm{~N}$ of Bopeechee, Lothian 1324, 6 Aug 1963 (AD, BRI, CANB, NSW).

\section{S. adenophylla J. Black}

\section{(J.M. Black 1926: 284)}

TyPE: SOUTH Australia: Finniss Springs, Francis D. Warren, 5 Sep 1926; holo AD; iso K, MEL, NSW (fragment).

S. microcalyx var. adenophylla (J. Black) J. Black (J.M. Black 1948: 475); S. microcalyx subsp. adenophylla (J. Black) A. Lee (A.T. Lee 1948: 207). TYPE: as for the species.

An erect or spreading perennial to c. $30 \mathrm{~cm}$ high, with numerous stems, often much branched near or below the soil-surface, from the top of a taproot. Stems 1-2(-3) $\mathrm{mm}$ wide, terete or bluntly angled below the nodes, the hairs often dense, mostly c. 0.5 $\mathrm{mm}$ long, narrowly elliptic, appressed, flat or turgid and medifixed, sometimes asymmetrically so. Leaves mostly 3-8 cm long, with 3-9 often turgid leaflets above a usually extended petiole, the leaflets narrow-linear to narrowly ovate-oblong, usually with a dense appressed pubescence on both surfaces, the laterals $15-25 \mathrm{~mm}$ long and usually $0.5-2 \mathrm{~mm}$ wide, of almost equal length, the terminal sometimes longer but sometimes less developed, the leaflet-apex mostly emarginate and usually with a very well-developed gland at the tip of the midvein that is often so large as to expand the tip; occasionally acute. Stipules minute or to c. $4 \mathrm{~mm}$ long, curved-deltoid to narrowly and long-acuminately deltoid, often with members of a pair conspicuously uneven, green, widely separated at the back, not forming an abaxial ridge and pubescent on both surfaces, especially on the margins. Racemes $10-20 \mathrm{~cm}$ long, with 10-20 flowers of almost even age. Peduncle $0.5-3 \mathrm{~mm}$ wide, with the pulvinus conspicuous and occasionally dark, with flowers usually in the upper $1 / 2$ but sometimes on $1 / 3$ or less, ribbed, with a close pubescence of appressed hairs. Bracts ovate-lanceolate, $c$. $1 \mathrm{~mm}$ long. Flowers purple, occasionally pink, 6-9 $\mathrm{mm}$ long, on, sometimes darkpubescent, pedicels 2-4 mm long. Hypanthium short and narrow, contracting at the apex under the fruiting calyx, the bracteoles minute. Calyx with the tube $2-2.5 \mathrm{~mm}$ long, only slightly and gradually expanding above the hypanthium, with a short, appressed, dense or sparse, sometimes dark, at least in part, pubescence, the lobes deltoid but with their apices contracted to acuminate tips, usually shorter than the tube, not dissimilar, the sinuses broadly rounded. Standard 7-9 $\mathrm{mm}$ long and a little less in width, gradually tapering or contracting to a tapered claw, with slender vertical thickenings. Wings 7-8 mm long, obovate-oblong, the apex shortly obtuse and usually much expanded and somewhat oblique (the lower edge longer), the claw long slender and curved, and little-tapered, the auricle deltoid with a central fold. Keel c. $7 \mathrm{~mm}$ long and c. $4 \mathrm{~mm}$ deep, with the apex obtuse or somewhat acute, and obscurely twisted sideways, with the upper margin straight or slightly raised in the centre, and with large pockets, the auricles rounded-deltoid to almost truncate, the claw long, slender, straight and without much taper. Ovary 3-4 mm long, elliptic, curved, with a dense pubescence, mostly appressed but raised somewhat towards the stipe, and often sparse or even absent from the non-sutural side, not tapered at the 
apex below the very broad style-base but tapered and oblique at the base. Ovules numerous. Stipe c. $0.5 \mathrm{~mm}$ long, broad, at least partly glabrous. Style very broadbased, laterally compressed and thickened from the base, tapering gradually to a narrow sometimes rather truncate tapered tip of variable size, strongly curved upward and twisted near the centre, the curvature slight above, the beard very dense in the upper $2 / 3$ and absent from the base; ovary hairs on the lowest part. Fruit (only one mature specimen seen) $10-20 \mathrm{~mm}$ long and c. $3 \mathrm{~mm}$ wide, narrow-oblong or slightly broader in the upper part, curved, inflated either side of the deeply and narrowly intruded suture, especially above the base, tapering at the base to a short, to c. $0.5 \mathrm{~mm}$, stipe, and at the apex tapering, rather broad and upturned, and bearing the remains of a stiff style c. 5-6 mm long that is recurved and looped from above the base, probably erect at maturity, the dehiscence not seen, with scattered, mostly appressed, hairs, the texture thinly leathery, the veins strongly raised but densely reticulate only on the sutural side, at c. $30^{\circ}-45^{\circ}$, the tissue rather short and not closing the loculus.

In eremean eastern South Australia, with isolated records for New South Wales and Victoria, in the far west and the Murray River valley. Usually on red, sandy, occasionally stony, flats, especially near lake-margins. Fig. 27.

Selected specimens (from c. 55 examined): South Australia: c. $15 \mathrm{~km}$ SE of Coward Springs railway station, along Margaret River, Chorney 906, 2 Oct 1978 (AD, NSW); near Andamooka Opalfield airstrip, Swinbourne 154, 7 Sep 1968 (AD, MEL, NT); Beavis Dam, Weber 1318, 5 Sep 1968 (AD, CANB, NSW). New South WaLes: Kinchega National Park, Mulham W769, Aug 1974 (NSW). Victoria: Barmah Forest, Chesterfield, 16 Jan 1979 (MEL).

\section{S. stipularis F. Muell.}

(F. Mueller 1852: 393)

TyPE: SOUTH Australia: prope Akaba, N. Holl. austr. interior, F. Mueller, Oct 1851; holo MEL; iso NSW (fragment).

IS. phacifolia F. Muell. (F. Mueller 1850), nomen nudum in synon. A specimen at K, Nov. Holl. austr. inter., Dr. F. Mueller, Herb. W. Sonder, named thus is S. murrayana.]

A spreading perennial with ascending stems, often c. $30 \mathrm{~cm}$ high, with several or numerous stems from the top of a taproot or occasionally a stout branched stock, the stem-bases often below the soil-surface. Stems $2-4(-5) \mathrm{mm}$ wide, terete or somewhat flattened or angled below the nodes, densely pubescent, the hairs often $0.75 \mathrm{~mm}$ or more in length, very narrowly elliptical, with long-tapered fine ends, mostly closely appressed but occasionally with the ends irregularly raised, very flat and thin, medifixed, sometimes asymmetrically, and sometimes raised above the stem at the point of attachment. Leaves 3-9 cm long, with 5-11 leaflets above a usually relatively long petiole, the leaflets from broadly linear-elliptic to broadly obcuneate or obcordate, with a dense loosely appressed pubescence on both surfaces, occasionally sparser above, the lower leaflets $1-25 \mathrm{~mm}$ long and $1-3(-6) \mathrm{mm}$ wide, the terminal a little to much longer than the upper laterals, the leaflet-apex acute with a short point to expanded and emarginate with a central tooth. Stipules to $15 \mathrm{~mm}$ long, usually very broad, often broader than long, with several broad acuminate lateral teeth, green, not forming an abaxial ridge and densely pubescent on both surfaces. Racemes $5-20 \mathrm{~cm}$ long, with 5 to more than 20 flowers of almost even age. Peduncle $0.5-3 \mathrm{~mm}$ wide, with the pulvinus often conspicuous, occasionally dark, with flowers occupying more than half to, when the peduncle is long, $1 / 5$ or less, conspicuously ribbed, pubescent, usually with some hairs irregular, occasionally with some dark towards the apex. Bracts ovate, 1-2 mm long. Flowers usually orange-red, often brown, occasionally 
yellow or purple, (7-)10-15 mm long on, often dark, pubescent pedicels of 1-3 mm or more. Hypanthium variable, sometimes rather slender and fluted, contracting somewhat at the apex under the fruiting calyx, the bracteoles small and narrow. Caly $x$ with the tube $2.5-3.5 \mathrm{~mm}$ long, mostly broadly but gradually and rather obliquely expanding above the hypanthium, with a dense appressed or partially irregular, and often dark, pubescence, the lobes deltoid, often somewhat acuminate, a little to much shorter than the tube, the upper somewhat shorter and broader, the sinuses broad and rounded. Standard 9-14 mm long and 10-15 mm wide, tapering or contracting to a broad tapered claw, with two small calli or a small central callus, or even without thickening. Wings 8-15 mm long, narrowly obovoid, the apex often obliquely expanded and shortly obtuse, the lower edge sometimes somewhat longer, the claw long, curved and gradually tapered, the auricle large, long and rounded, usually conspicuously recurved and folded. Keel 8-14 mm long and c. $5 \mathrm{~mm}$ deep, with the apex obtuse and somewhat upcurved and laterally twisted, with the upper margin descending from the raised tip, then raised in the centre, and with the pockets large but often obscure, the auricles small, rounded and close to the rather long, narrow and straight claw. Ovary 4-6 mm long, elliptic, curved, with a dense pubescence appressed, except near the base where raised, sometimes more dense near the suture and occasionally sparse below in the apical part, with little taper behind the broad style-base and tapered more suddenly and obliquely at the base. Ovules numerous. Stipe c. $0.5 \mathrm{~mm}$ long, broad, and at least partly glabrous. Style very broad-based, strongly laterally compressed, especially at the base, pale and very stiff for most of its length, curved, more strongly at the base and apex, often tending to twist slightly near the base, the area behind the tip flattened (in the other dimension) below the tip, tapering, curved, narrow and less stiffened, the beard dense and antrorse on the short flattened section and on the tip, absent from most of the style. Fruit 10-30 mm long and 3-5 mm wide, narrowly obovoid or somewhat fusiform, inflated either side of the deeply indented suture, somewhat dorsiventrally compressed, narrowing somewhat, and long-tapering to the very short stipe c. $0.5 \mathrm{~mm}$ long, and more suddenly to, or rounded behind, the somewhat beaklike and often shortly and slightly upturned apex with the remains of the c. $9 \mathrm{~mm}$ style, becoming erect at maturity, tardily dehiscent along the suture, rather softly and closely pubescent, the texture stiffly leathery, the veins sometimes somewhat raised, at $45^{\circ}-60^{\circ}$, the tissue deep and sealing the loculus.

From Adelaide through the Flinders Ranges to central northern South Australia (perhaps reaching the Northern Territory), and from the Broken Hill district of New South Wales northward to the south-west corner of Queensland. On red sandy, stony or clay flats or slopes, in grassland, saltbush, mulga or mallee, usually associated with ridges or ranges. Fig. 27.

Selected specimens (from c. 300 examined): South Australia: Pichi Richi Pass, $22 \mathrm{~km}$ SW of Quorn, Kraehenbuehl 3288, 10 Oct 1971 (AD, NT); $35 \mathrm{~km}$ NE of Yunta towards Cockburn, Sikkes 1258 \& Ollerenshaw, 29 Sep 1973 (CBG, K, NSW). QueENSLAND: between the Paroot [Paroo River] and Grey Range, Morton, 1881 (MEL). NEW SOUTH WALES: The Gorge, NE of Broken Hill, Fox 8708331 \& Norris, 6 Sep 1987 (NSW); Byrnedale Station, c. 35 miles [56 km] N of Menindee, Parker, 24 July 1968 (CANB, NSW).

\section{S. eremaea J. Thompson, sp. nov.}

Herba patens probabiliter perennis forsan usque ad $30 \mathrm{~cm}$ alta. Foliola 5-11 linearoelliptica vel -oblonga usque ad late cuneata vel obcordata. Racemi 5-20 cm longi floribus $8-10 \mathrm{~mm}$ longis. Calyx lobis tubo plerumque brevioribus. Vexillum versus basim callis parvis duobis. Carina late obtusa. Stylus valde complanatus incrassatus ad apicem extensione curvato. Fructus $10-15 \mathrm{~mm}$ longus 3-4 mm latus plerumque angusto-obovatus. 
TyPe: SOuth Australia: $10 \mathrm{~km}$ SE of William Creek, F.J. Badman 1375, 27 July 1984; holo NSW; iso AD, CANB.

A low-growing spreading, probably perennial, plant to perhaps $30 \mathrm{~cm}$ high, with a number of, probably initially erect, stems from the top or from near the top of a taproot. Stems often 2-4 mm wide, terete or sometimes somewhat flattened, densely pubescent, the hairs often $0.75 \mathrm{~mm}$ long, very narrowly elliptical, with long-tapered fine ends, mostly closely appressed but some with the ends irregularly raised, very flat and thin, medifixed, sometimes asymmetrically, and sometimes raised above the point of attachment. Leaves 2-9 cm long, with 5-11 leaflets above a usually relatively short petiole, the leaflets linear-elliptic or -oblong to broadly cuneate or obcordate, with a dense close pubescence on both surfaces or occasionally with the upper surface almost glabrous, the lower leaflets $1-c$. $15 \mathrm{~mm}$ long and 1-3(-5) $\mathrm{mm}$ wide, the terminal about twice the length of the laterals, the leaflet-apex recurved and acute but scarcely pointed, to expanded and emarginate often with a central broad tooth, i.e. trilobed. Stipules to $15 \mathrm{~mm}$ long, usually very broad with several broad acuminate lateral teeth, green, not forming an abaxial ridge and densely pubescent on both surfaces. Racemes 5-20 cm long, with 5 to more than 20 flowers of even age. Peduncle (1-)1.5-2.5 mm wide, with the pulvinus conspicuous, densely pubescent and often dark, with flowers usually occupying a little more or less than $1 / 2$ the length, usually conspicuously ribbed, pubescent, often with some hairs irregular, rarely with some dark towards the apex. Bracts broad-lanceolate or elliptic, 1-2 mm long. Flowers bright red to brown or yellow, 8-10 mm long, on, usually dark, pubescent pedicels 1-2 mm long. Hypanthium short, contracting somewhat at the apex under the fruiting calyx, the bracteoles small and narrow. Calyx with the tube 2-2.5 $\mathrm{mm}$ long, variably and rather obliquely, but usually not strongly, expanded above the hypanthium, with a dense appressed or partially irregular, and often dark, pubescence, the lobes deltoid and usually acuminate, shorter than or occasionally equal to the tube, the upper a little shorter and often slightly broader, the sinuses usually broad and rounded. Standard 9-11 $\mathrm{mm}$ long and 8-12 $\mathrm{mm}$ wide, tapering at the base to a tapered claw, with two small high calli at the base. Wings 10-15 mm long, obovoid, with the apex often obliquely expanded, shortly obtuse, the lower edge sometimes somewhat longer, the claw long, curved and gradually tapered, the auricle large and long, rounded, usually conspicuously recurved and folded. Keel $8-9 \mathrm{~mm}$ long and c. $4 \mathrm{~mm}$ deep, with the apex broadly obtuse or even rather truncate with the tip raised, little, if at all, twisted, with the upper margin variable, usually descending behind the raised tip and then raised so that the auricle is deep and rounded, and with the pockets obscure or absent, the claw rather long, narrow and straight. Ovary c. $4 \mathrm{~mm}$ long, narrowly ovoid, curved with a dense pubescence appressed except near the base where raised, not or little tapered behind the broad style-base and suddenly and obliquely at the base. Ooules numerous. Stipe c. $0.5 \mathrm{~mm}$ long, stout, mostly glabrous. Style very broadbased, strongly laterally compressed, pale and very stiff in the upper $2 / 3$, not twisted, evenly curved or somewhat straighter in the upper part, the tip narrowly rounded with a short slender, usually curved, extension, the beard dense and antrorse but confined to a small area behind and on the tip. Fruit 10-15 mm long and 3-4 mm wide, mostly narrowly obovoid, inflated either side of a deeply intruded suture, occasionally somewhat dorsiventrally compressed, rather abruptly narrowing at the base to a stipe c. $0.5 \mathrm{~mm}$ long and at the apex to a very short, usually upturned, beak bearing the irregularly twisted remains of the c. $6 \mathrm{~mm}$ style, becoming erect at maturity, tardily dehiscent along the suture, with a closely appressed pubescence, the texture stiffly leathery, the veins conspicuously raised, at $60^{\circ}$, the tissue deep, especially in the centre of the loculus and closing it. 
In central northern South Australia. In sandy, or occasionally stony, soil, on floodplain. Fig. 27.

From the Greek eremia, a desert.

Selected sPecimens (from c. 30 examined): SOUTh Australia: Mt Kingston, Stuart (MEL); 8 miles [13 km] from William Creek on Marree road, Gittins 02724, Aug 1973 (AD, BRI, NSW); along track beside Goyder Channel, Lake Eyre, Corrick 5064, 10 Aug 1971 (MEL); Western Hunt Peninsula, just N of Muloorina Homestead, Cornwall 117, 21 Sep 1968 (AD); Beresford, Ising 2603, 21 Aug 1931 (AD).

\section{Nomina Incognita}

S. osbornii var. atropurpurea Henderson \& A. Henderson (E.G. \& A. Henderson 1864: sub t.69). No specimen is cited but the description is of a plant 'with velvety leaves'.

S. phacoides var. erecta E. Pritzel (E.G. Pritzel 1918: 357). Type citation: 'Australia centralis: districtu C. sec. cl. Tate, leg. Basedow no. 64, 337, 513'; ?, n.v.

\section{Acknowledgements}

I would like to thank the Directors of the Australian herbaria, AD, BRI, CANB, CBG, HO, MEL, NT and PERTH, for lending me their collections, and the Directors of Kew and the Natural History Museum, London, and the Professor of Botany at Trinity College, Dublin, for access to their collections. The National Herbarium of New South Wales, Royal Botanic Gardens, Sydney, has been most helpful in providing generous support and a large collection for study. The manuscript was ably typed by their staff, especially Angela Benn, and my maps and drawings put into a suitable form for publication by Peter Richards and Marion Westmacott. I would particularly like to thank Peter Weston for his suggestions on the structure and content of the introductory text, and Peter Wilson for his critical and helpful comments on the final manuscript. Funding from the Australian Biological Resources Study is most gratefully acknowledged.

\section{References}

Aiton, W.T. (1812) Hortus Kewensis, edn 2, vol. 4.

Andrews, H.C. (1803) The botanist's repository.

Ascherson, P.F.A. \& Graebner, K.O.R.P.P. (1909) Synopsis der Mitteleuropäischen Flora, vol. 6.

Bailey, F.M. (1883) A synopsis of the Queensland flora.

Bailey, F.M. (1910) Contributions to the flora of Queensland. Queensland Agric. J. 25: 286-290.

Bailey, L.H. (1902) Cyclopedia of American horticulture, vol. 4.

Barneby, R.C. (1964) Atlas of North American Astragalus. Mem. New York Bot. Gard. 13: 1-1188.

Bentham, G. (1864) Flora Australiensis, vol. 2.

Bentham, G. (1866) Handbook of the British Flora, edn 2.

Black, J.M. (1924a) Flora of South Australia, part 2.

Black, J.M. (1924b) Additions to the flora of South Australia. Trans. \& Proc. Roy. Soc. South Australia 48: 253-257.

Black, J.M. (1926) Additions to the flora of South Australia. Trans. \& Proc. Roy. Soc. South Australia 50: 283-285.

Black, J.M. (1927) Additions to the flora of South Australia. Trans. \& Proc. Roy. Soc. South Australia 51: 378-385.

Black, J.M. (1928) Additions to the flora of South Australia. Trans. E Proc. Roy. Soc. South Australia 52: 225-230.

Black, J.M. (1930) Additions to the flora of South Australia. Trans. E Proc. Roy. Soc. South Australia 54: 59-61. 
Black, J.M. (1933) Additions to the flora of South Australia. Trans. \& Proc. Roy. Soc. South Australia 57: 143-158.

Black, J.M. (1935) Additions to the flora of South Australia. Trans. \& Proc. Roy. Soc. South Australia 59: 252-262.

Black, J.M. (1948) Flora of South Australia, edn 2, part 2.

Black, J.M. (1965) Flora of South Australia, edn 2, suppl.

Candolle, A.P. de (1825a) Ann. Sci. Nat., ser. 1, 4: 90-103.

Candolle, A.P. de (1825b) Prodromus systematis naturalis regni vegetabilis, vol. 2.

Carrière, E.A. (1886) Revue Horticole., vol. 58.

Carrière, E.A. (1887) Revue Horticole., vol. 59.

Diels, L. \& Pritzel, E.G. (1904) Fragmenta phytographiae australiae occidentalis. Bot. Jahrb. Syst. 35: 55-662.

Dombrain, H.H. (1866) The floral magazine, vol. 5.

Domin, K. (1926) Bibliotheca Botanica, vol. 89.

Don, G. (1832) A general history of the dichlamydeous plants, vol. 2.

Dumont de Courset, G.L.M. (1814) Le botaniste cultivateur, vol. 7 (supp.).

Fellows, Linda (1989) Botany breaks into the candy store. New Scientist, Aug. 26: 29-32.

Fitzgerald, W.V. (1904) Additions to the West Australian flora. J. Western Australia Nat. Hist. Soc. 2: 5.

Ford, N.C. \& Vickery, J.W. (1950) The correct name of Sturt's Desert Pea, Clianthus formosus (G. Don) comb. nov. Contr. New South Wales Natl. Herb., 1(5): 302-303.

Gray. A. (1854) United States exploring expedition, Botany, vol. 1.

Guilfoyle, W.R. (1909) Australian plants.

Henderson, E.G. \& Henderson, A. (1864) The illustrated bouquet, vol. 3.

Henfry, A., Moore, T. \& Ayres, W.P. (1852) Garden companion and florists guide.

Hooker, J.D. (1867) Handbook of the New Zealand Flora.

Hooker, W. \& Salisbury, R.A. (1806) The paradisus londinensis.

Hort. (?auct.) (1863) Illustrierte Gartenzeitung 7(11).

Lee, A.T. (1948) The genus Swainsona. Contr. New South Wales Natl. Herb. 1(4): 131-271.

Lindley, J. (1826) Edward's Botanical Register, vol. 12.

Lindley, J. (1835) Trans. Hort. Soc. London, ser. 2, 1: 519-522.

Lindley, J. (1839) A sketch of the vegetation of the Swan River Colony.

Lindley, J. (1846) Edward's botanical register, n. ser., vol. 9.

Loddiges, C. (1830) The botanical cabinet.

Maiden, J.H. \& Betche, E. (1903) Notes from the Botanic Gardens, Sydney, No. 9. Proc. Linn. Soc. New South Wales 28: 904-923.

Maiden, J.H. \& Betche, E. (1916) A census of New South Wales plants.

Mitchell, T.L. (1848) Journal of an expedition into the interior of tropical Australia.

Moore, C. \& Betche, E. (1893) Handbook of the flora of New South Wales.

Mueller, F. (1850) Notes on South Australian botany. South Australian Register. 14: 3.

Mueller, F. (1852) Diagnoses et descriptiones plantarum novarum, quas in Nova Hollandia australi praecipue in regionibus interioribus. Linnaea 25: 367-445.

Mueller, F. (1859a) Fragmenta phytographiae Australiae, vol. 1.

Mueller, F. (1859b) Enumeration of plants collected by A.C. Gregory, Esq. along and near Cooper's River and its tributaries in sub-central Australia. New South Wales Legislative Assembly votes \& proceedings, vol. 2.

Mueller, F. (1862) Fragmenta phytographiae Australiae, vol. 3.

Mueller, F. (1863) Plants collected in Capricornic Western Australia by H.S. King. Trans. Bot. Soc. Edinburgh 7: 49-57.

Mueller, F. (1869) Fragmenta phytographiae Australiae, vol. 7.

Mueller, F. (1874) Fragmenta phytographiae Australiae, vol. 8.

Mueller, F. (1875) Fragmenta phytographiae Australiae, vol. 9.

Mueller, F. (1876) Fragmenta phytographiae Australiae, vol. 10.

Mueller, F. (1879) Fragmenta phytographiae Australiae, vol. 11.

Mueller, F. (1882) Definitions of some new Australian plants. S. Sci. Rec. 2: 149-152.

Mueller, F. (1884) Notes on an undescribed Victorian species of Swainsona. Australas. Chem. Druggist $7: 45$.

Mueller, F. (1887a) Notes on Australian Plants. Australas. Chem. Druggist $2: 84$. 
Mueller, F. (1887b) Record of the plants collected by Mr Pemberton Walcott and Mr Maitland Brown in the year 1861, during Mr F. Gregory's exploring expedition into north-western Australia. Trans. \& Proc. Roy. Soc. Victoria 23: 479-500.

Mueller, F. (1892) Descriptions of new Australia plants, with occasional other annotations. Victorian Naturalist 8: 136-137.

Polhill, R.M. \& Raven, P.H. (eds) (1981) Advances in Legume systematics.

Price, W.R. (1910) Decades kewenses. Decas LIX. Kew Bull. 1910: 381-386.

Pritzel, E.G. (1918) Species novae ex Australia central; Repertorium specierum novarum regni vegetabilis, vol. 15: 256-361.

Regel, E.A. von (1854) Gartenflora, vol. 3.

Regel, E.A. von (1887) Index seminum quae Hortus Botanicus Imperialis Petropolitanus.

Sanderson, M.J. (1991) Phylogenetic relationships within North American Astragalus (Fabaceae). Syst. Bot. 16 (3): 414-430.

Simpson, G. (1945) Notes on some New Zealand plants and descriptions of new species. Trans. Roy. Soc. New Zealand 75: 187-202.

Sims, J. (1804) The Botanical Magazine.

Sprague, T.A. (1903) New or noteworthy plants. Gard. Chron. 33 (852): 274.

Steenis, C.G.G.J. van \& Bakhuizen van de Brink, R.C. (1967) Miscellaneous Botanical Notes XVI. Bot. Jahrb. Syst. 86: 385-401.

Sturt, C. (1849) Narrative of an expedition into Central Australia.

Thompson, J. (1990) New species and combinations in the genus Swainsona. Telopea 4(1): 1-5.

Thompson, J. (1991) Swainsona pyrophila (Fabaceae), a new name and synonymisation. Telopea 4(2): 359 .

Wawra von Fernsee, H.R. (1881) Oesterr. Bot. Z. 31: 61.

Weber, J.Z. (1985) A new species of Swainsona (Fabaceae). Journ. Adelaide Bot. Gard. 7(3): 301302.

White, C.T. \& Francis, W.D. (1926) Contributions to the Queensland flora, No. 3. Proc. Roy. Soc. Queensland 37: 152-167.

Manuscript received 1 July 1992

Manuscript accepted 6 August 1993 


\section{Distribution maps of Swainsona species}

(Numbering is from left to right, top to bottom)
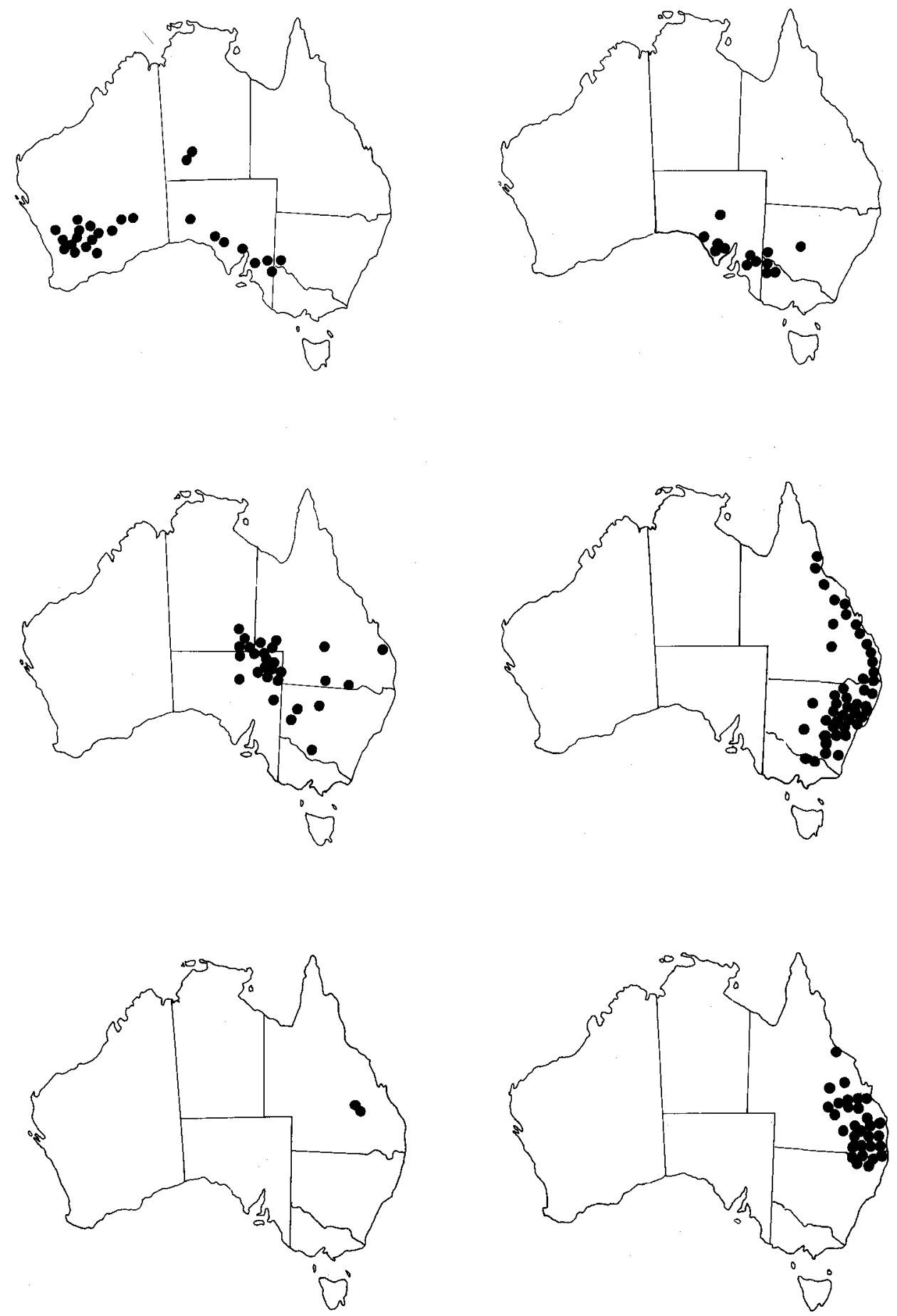

Figure 8. Distribution of Group 1, species 1-6. 1, S. colutoides; 2, S. pyrophila; 3, S. laxa; 4, S. galegifolia; 5, S. sejuncta; 6, S. queenslandica. 

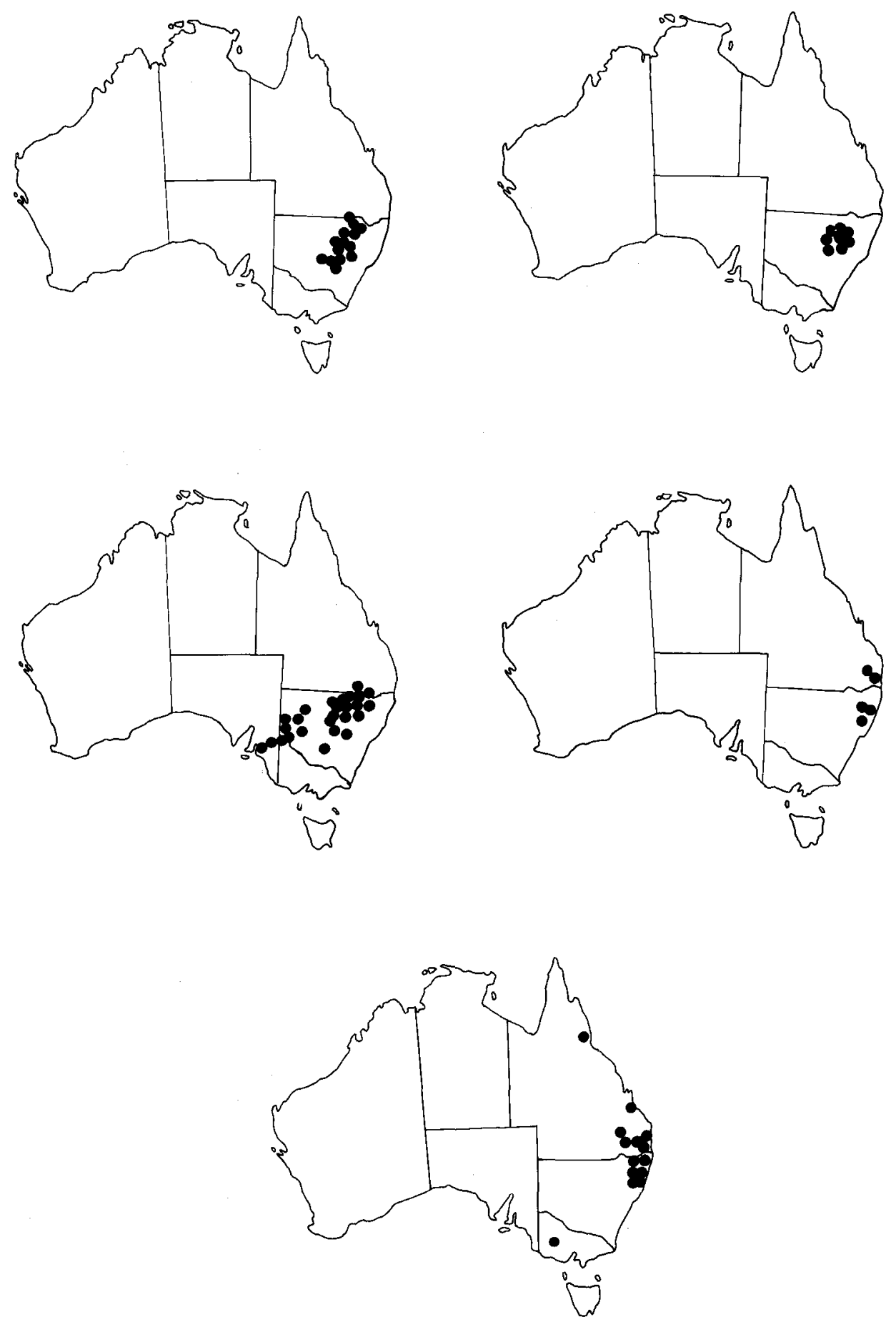

Figure 9. Distribution of Group 1, species 7-11. 7, S. bracteata; 8, S. cadellii; 9, S. greyana; 10, S. fraseri; 11, S. brachycarpa. 

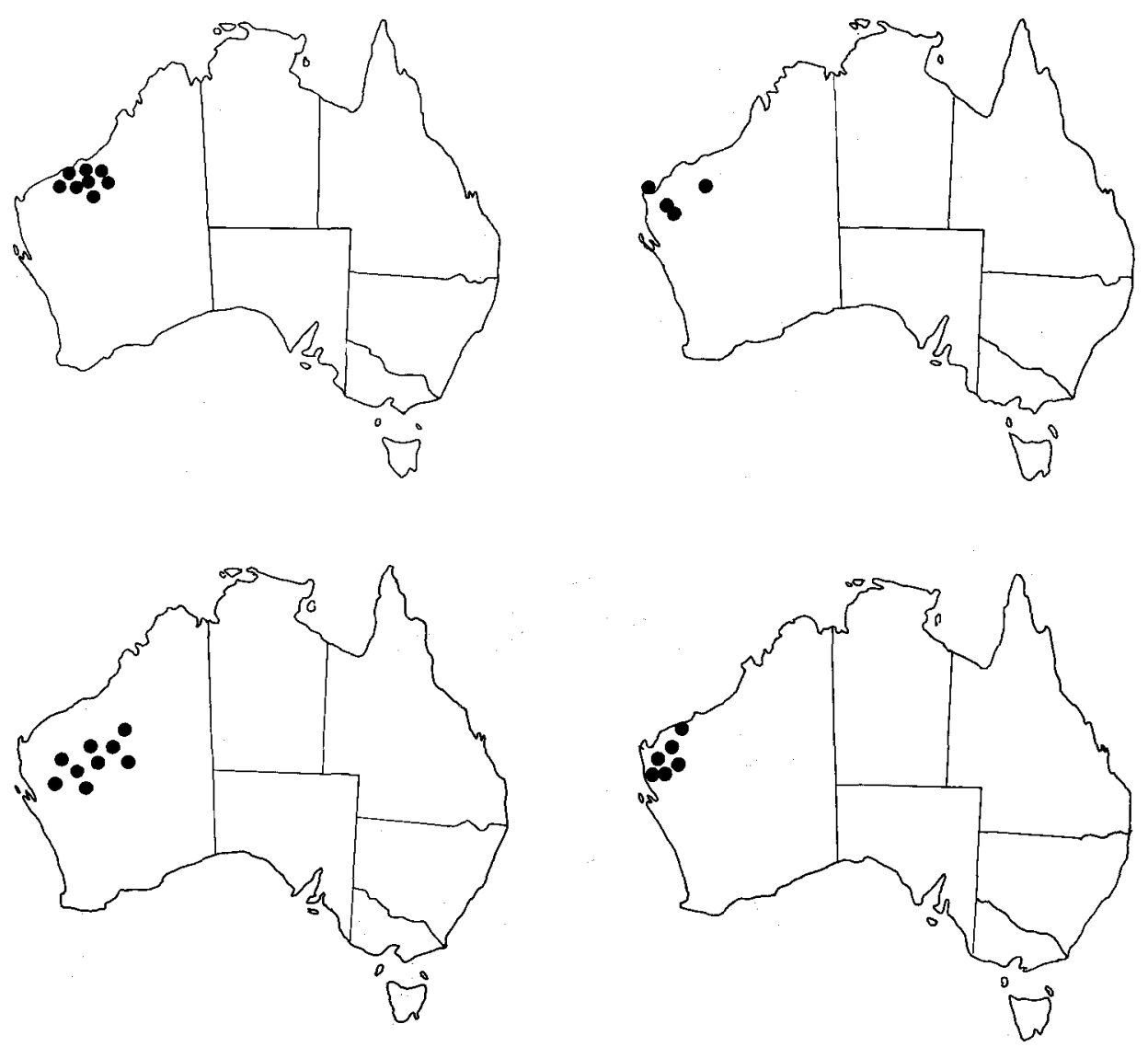

Figure 10. Distribution of Group 2, species 12-15. 12, S. stenodonta; 13, S. complanata; 14, S. elegantoides; $15, S$. forrestii. 

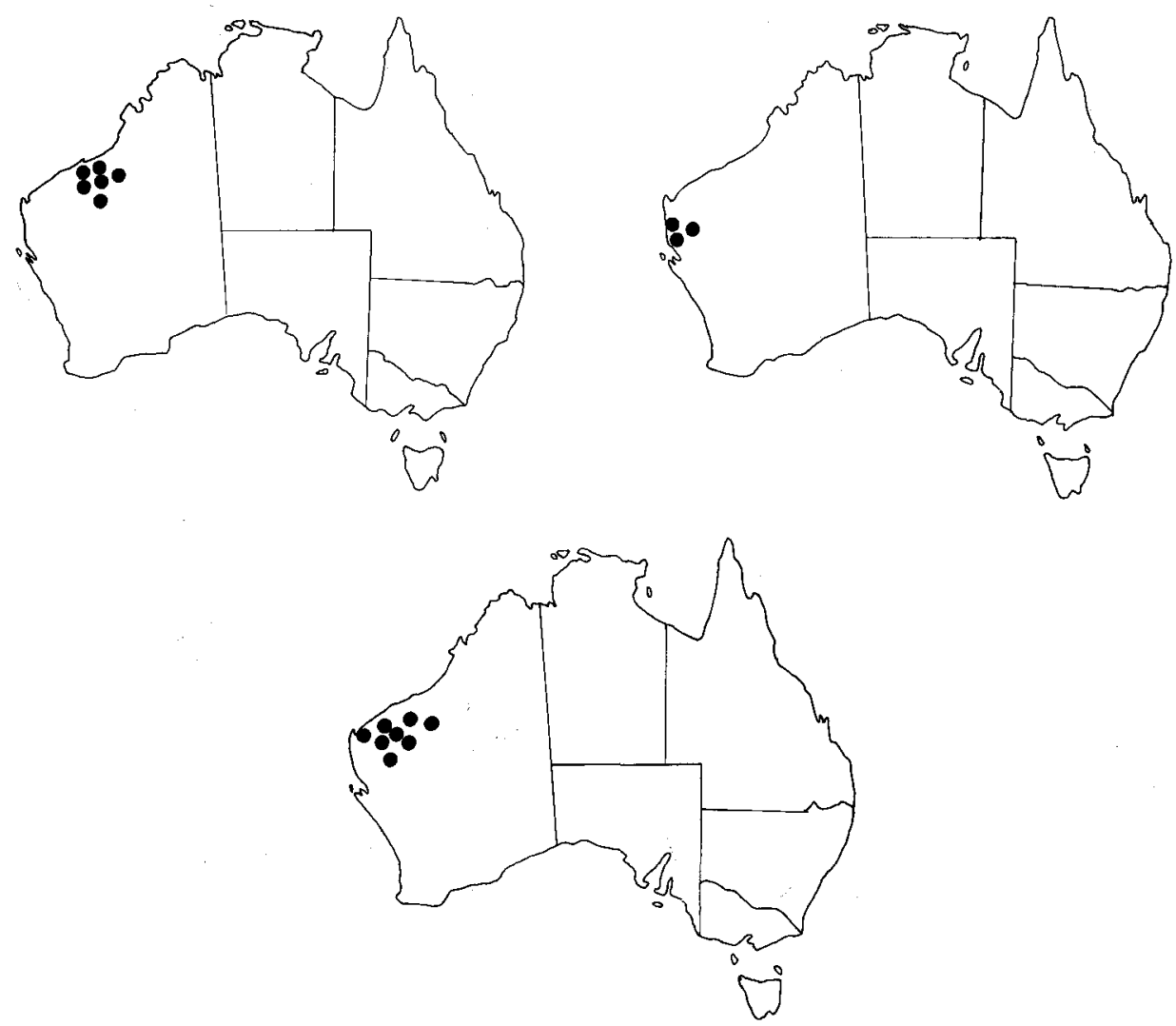

Figure 11. Distribution of Group 2, species 16-18. 16, S. decurrens; 17, S. ecallosa; 18, S. maccullochiana. 

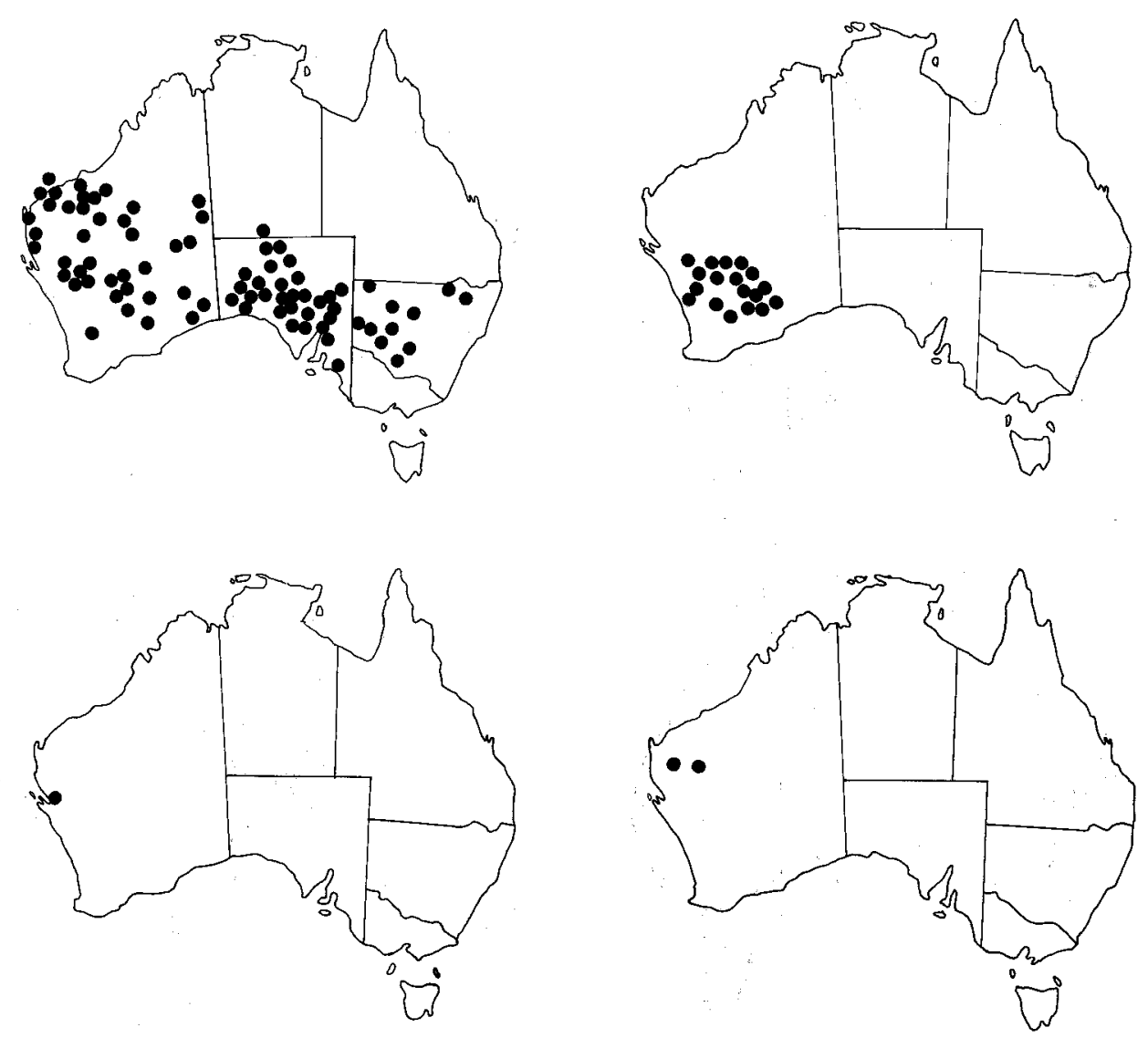

Figure 12. Distribution of Group 3, species 19-22. 19, S. formosa; 20, S. beasleyana; 21, S. cornuta; 22, S. 1ongipilosa. 

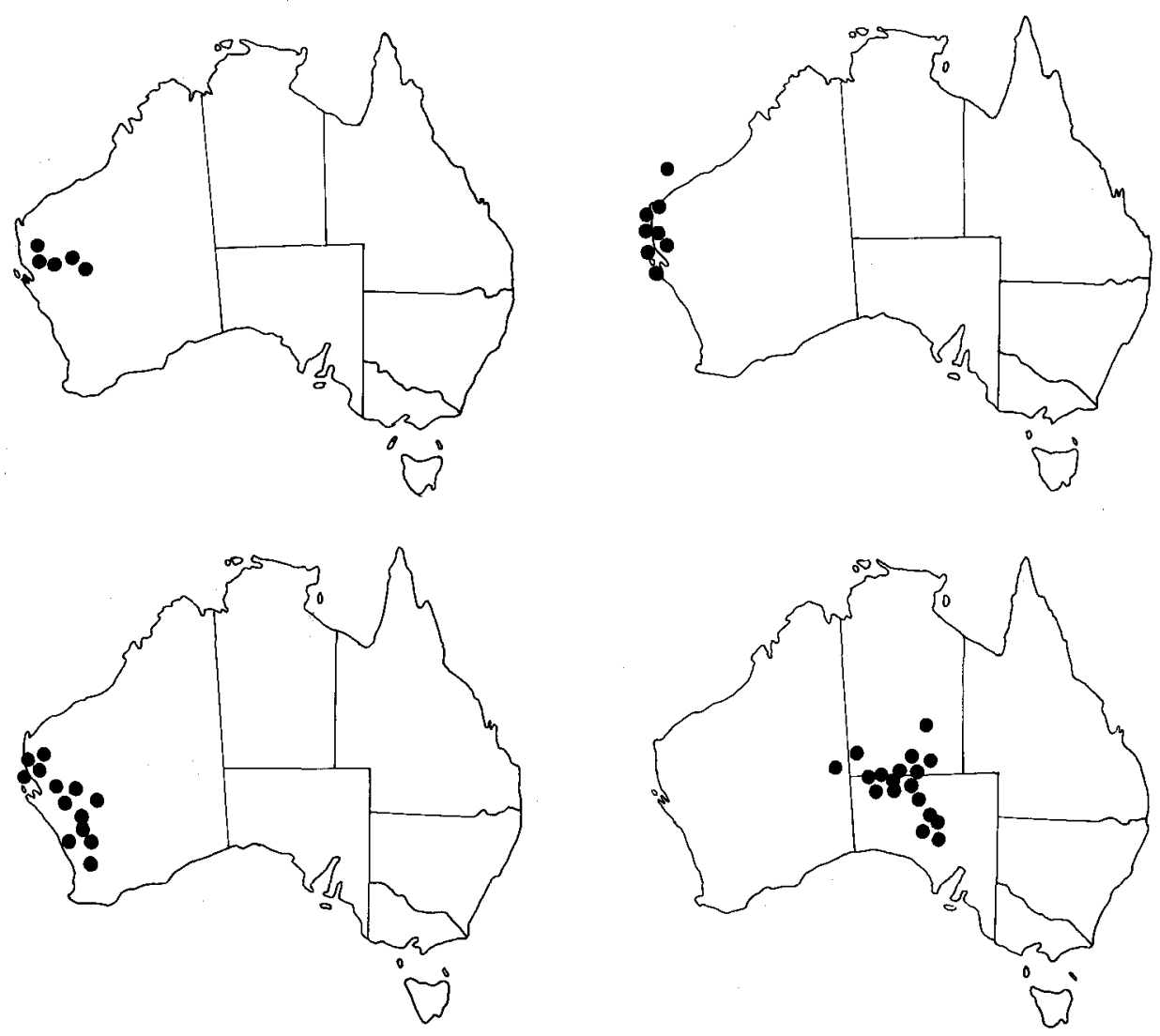

Figure 13. Distribution of Group 3, species 23-26. 23, S. pedunculata; 24, S. calcicola; 25, S. elegans; 26, S. villosa. 

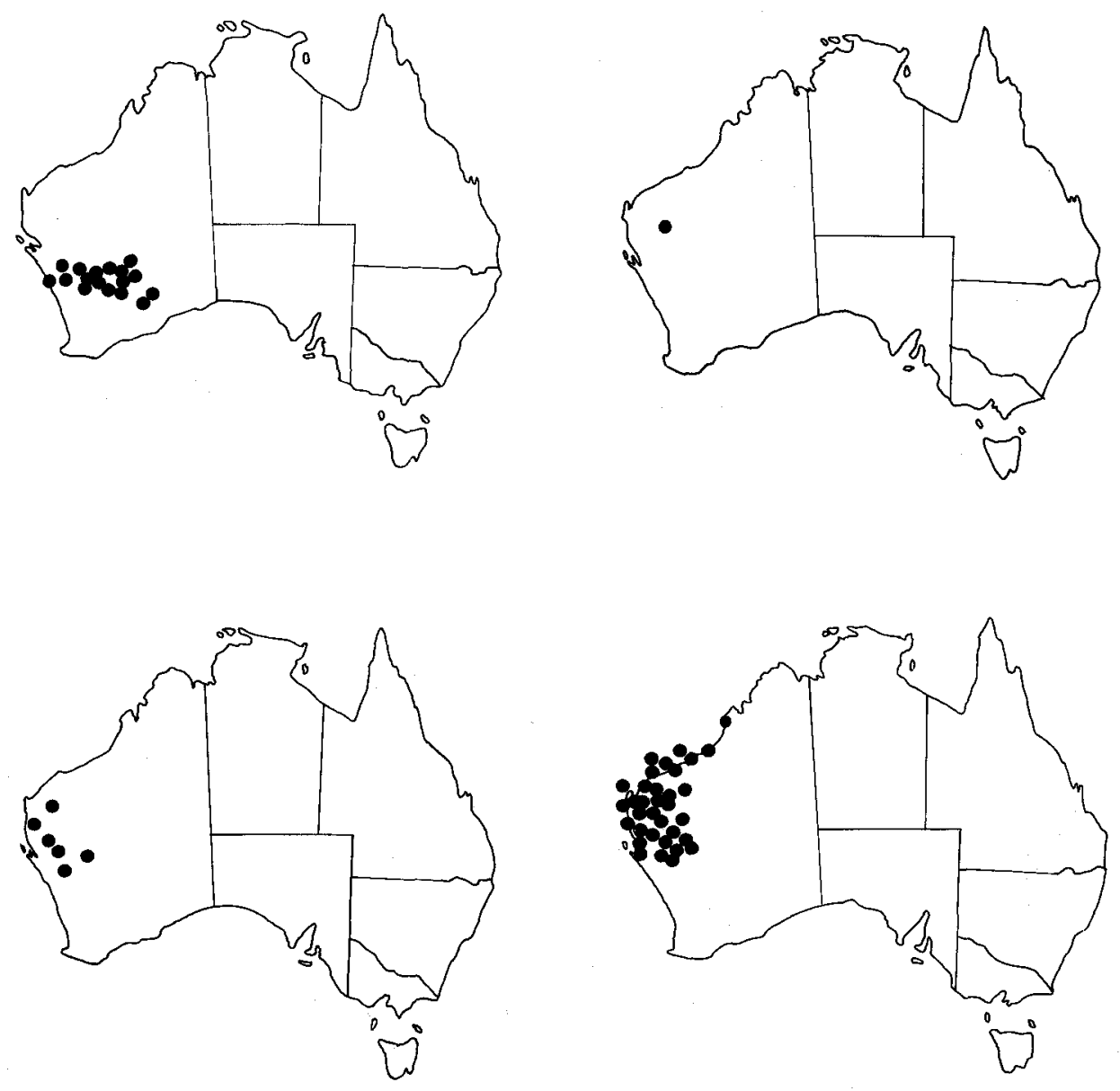

Figure 14. Distribution of Group 4, species 27-30. 27, S. rostellata; 28, S. rotunda; 29, S. gracilis; 30, S. pterostylis. 

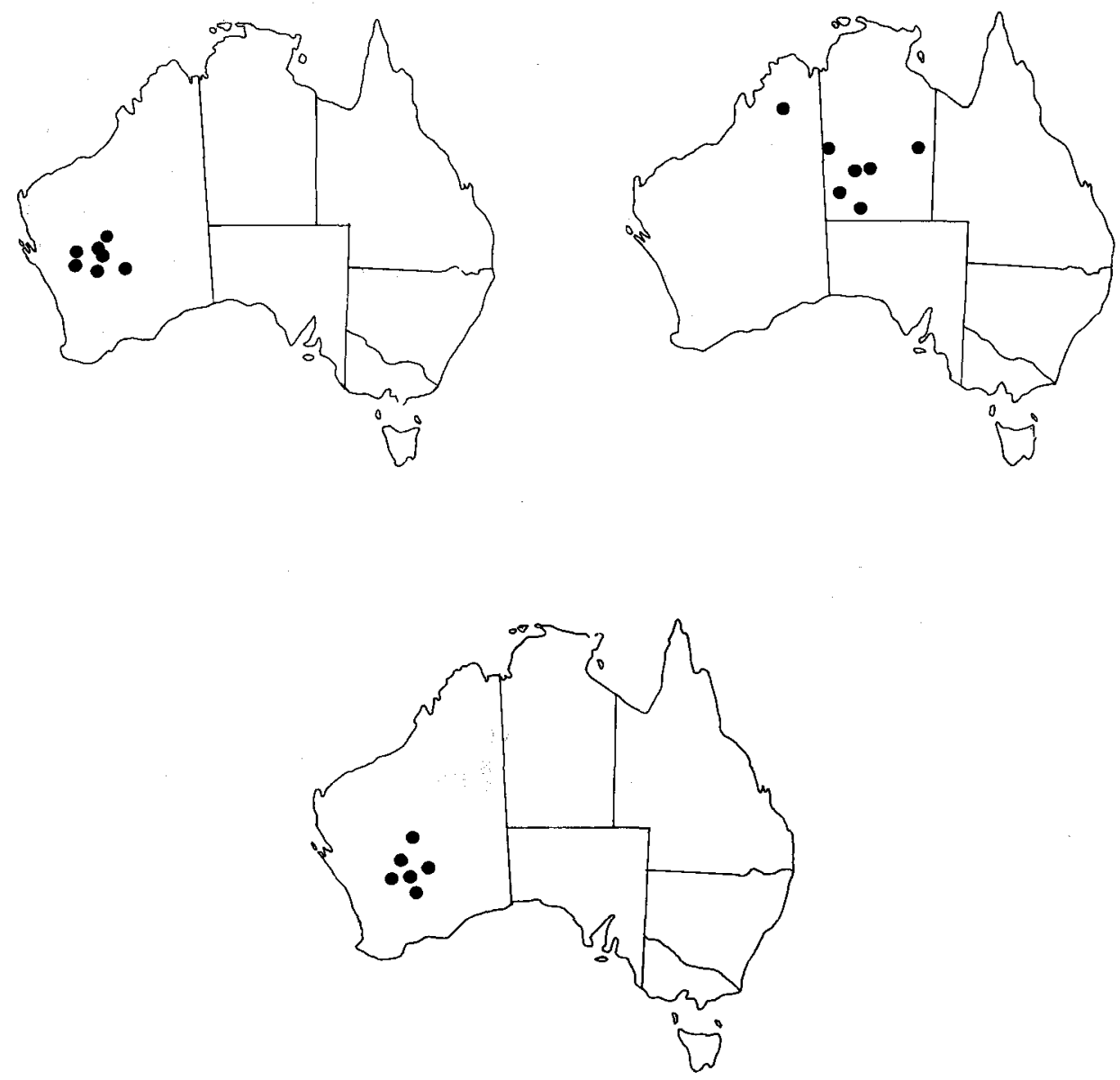

Figure 15. Distribution of Group 5, species 31-33. 31, S. paradoxa; 32, S. cyclocarpa; 33; S. halophila. 

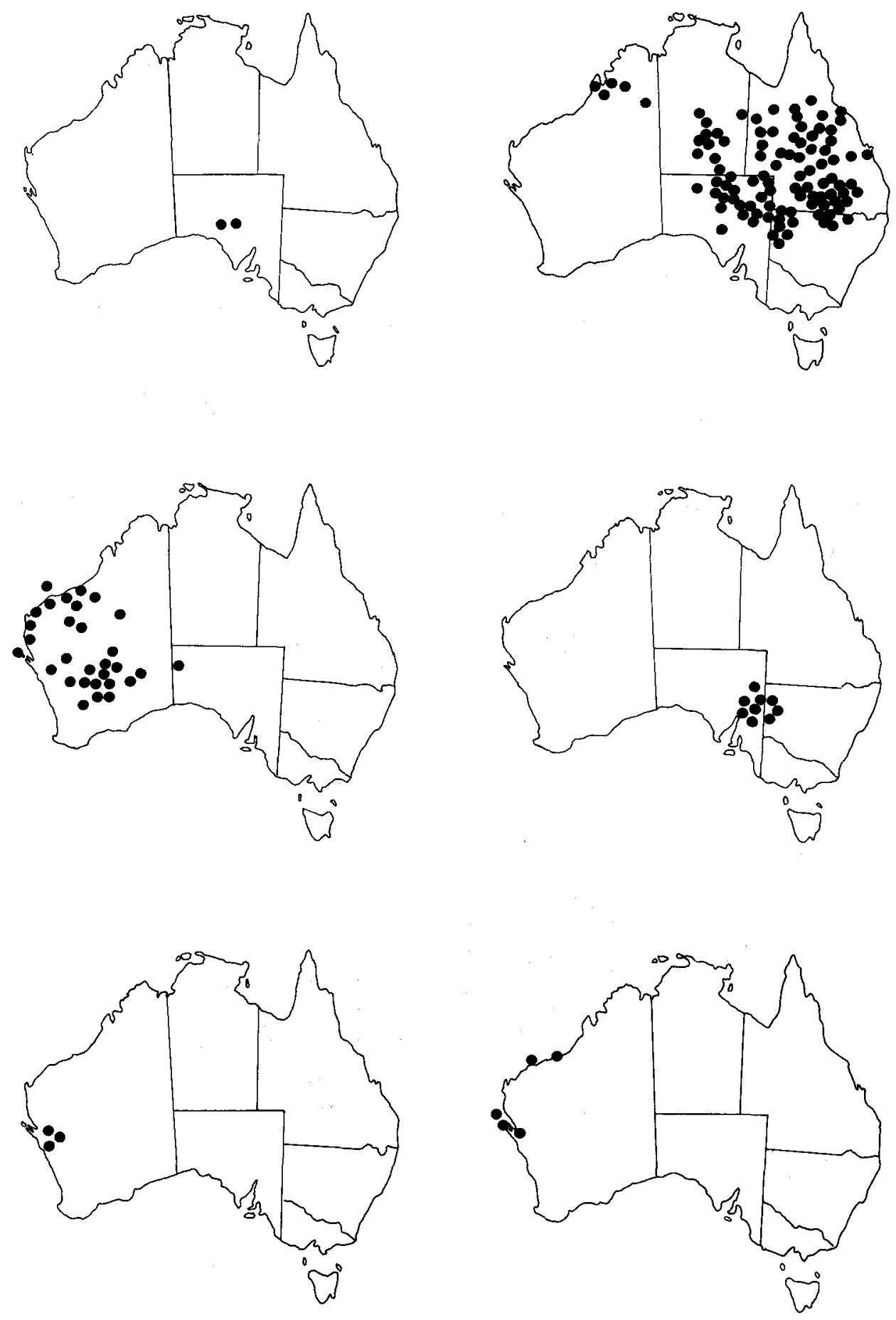

Figure 16. Distribution of Group 6, species 34-39. 34, S. dictyocarpa; 35, S. campylantha; 36, S. kingii; 37, S. viridis; 38, S. perlonga; 39, S. 1ongicarinata. 

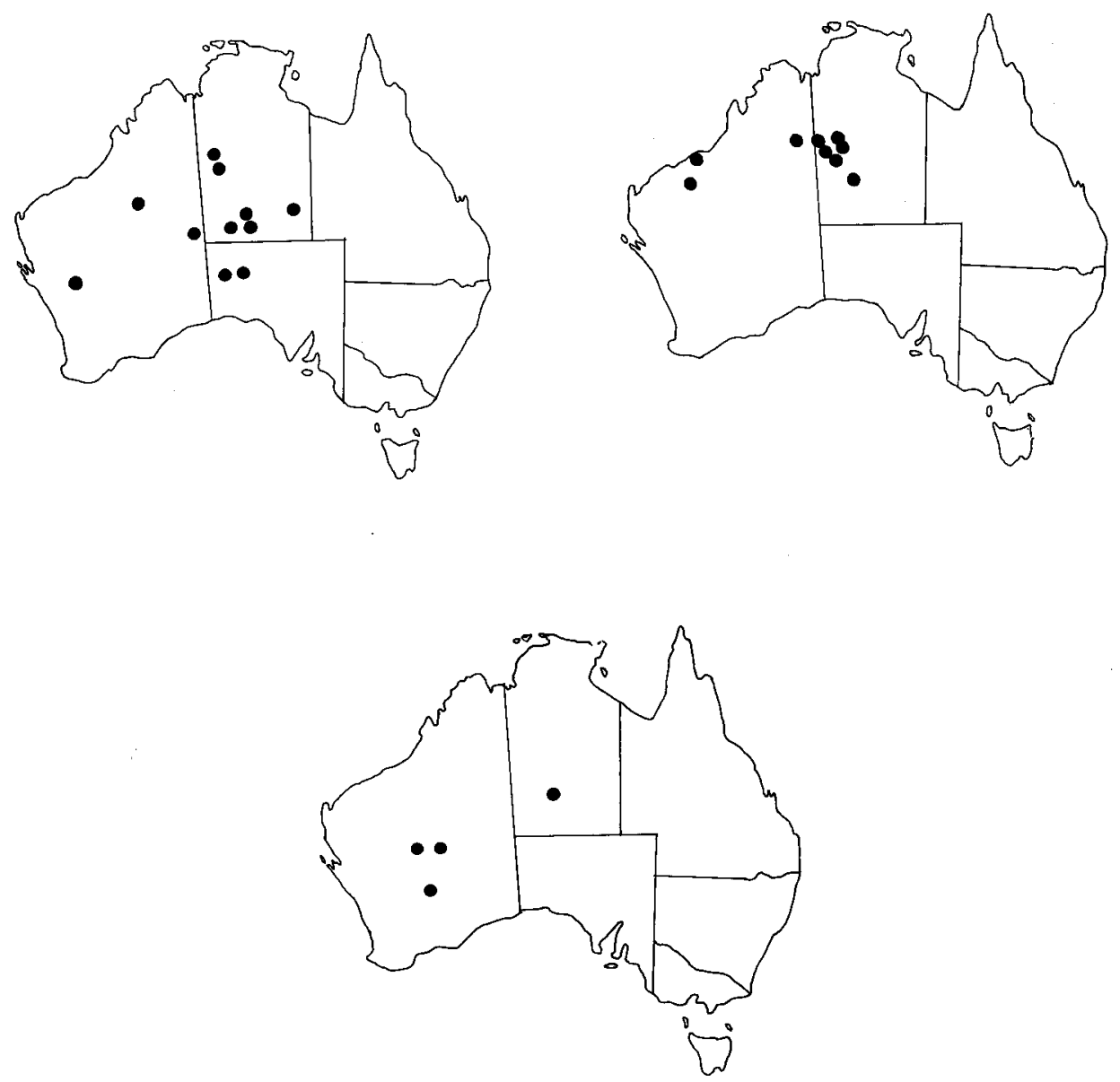

Figure 17. Distribution of Group 6, species 40-42. 40, S. unifoliolata; 41, S. tanamiensis; 42, S. laciniata. 

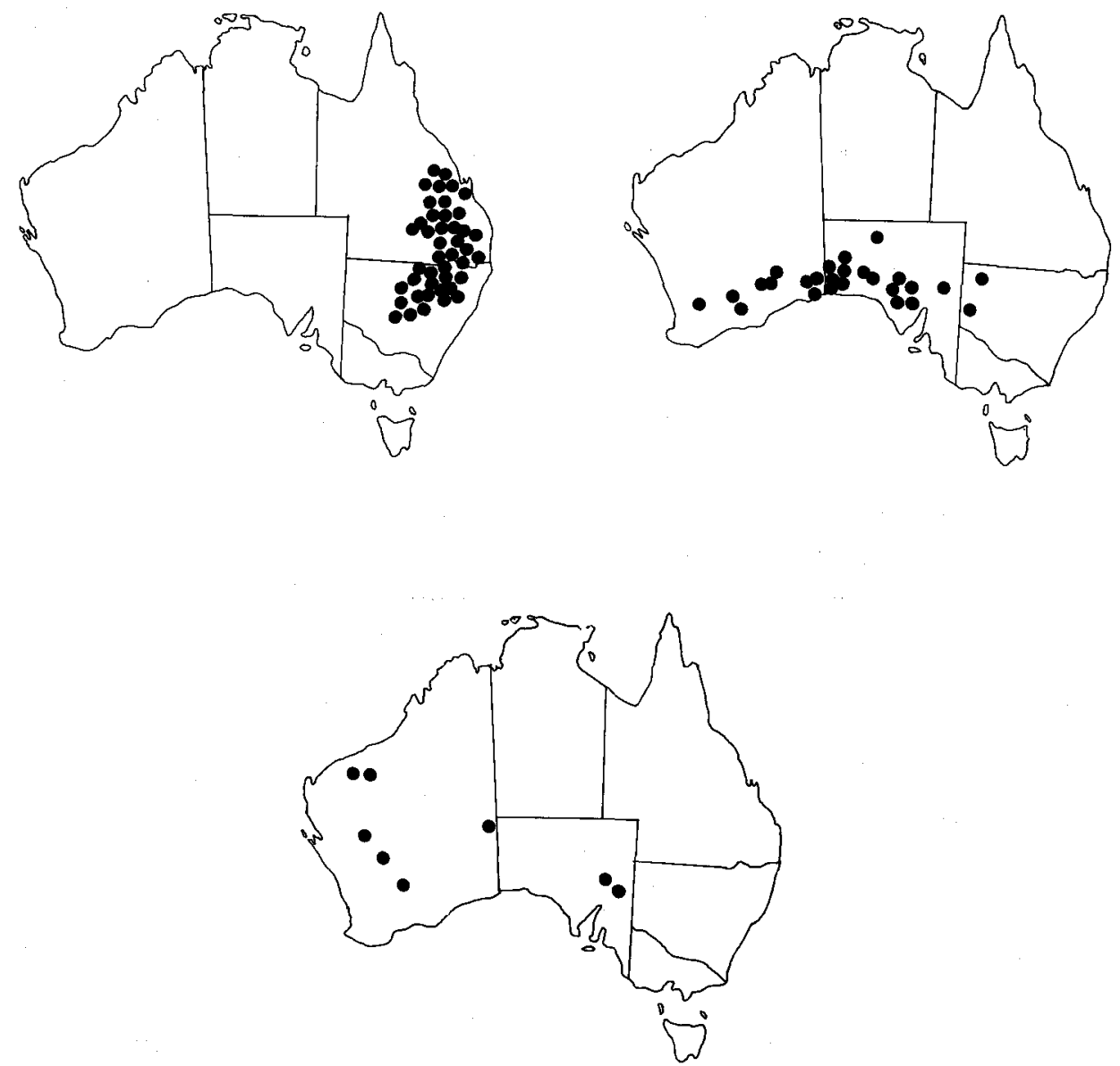

Figure 18. Distribution of Group 7, species 43-45. 43, S. luteola; 44, S. oliveri; 45, S. leeana. 

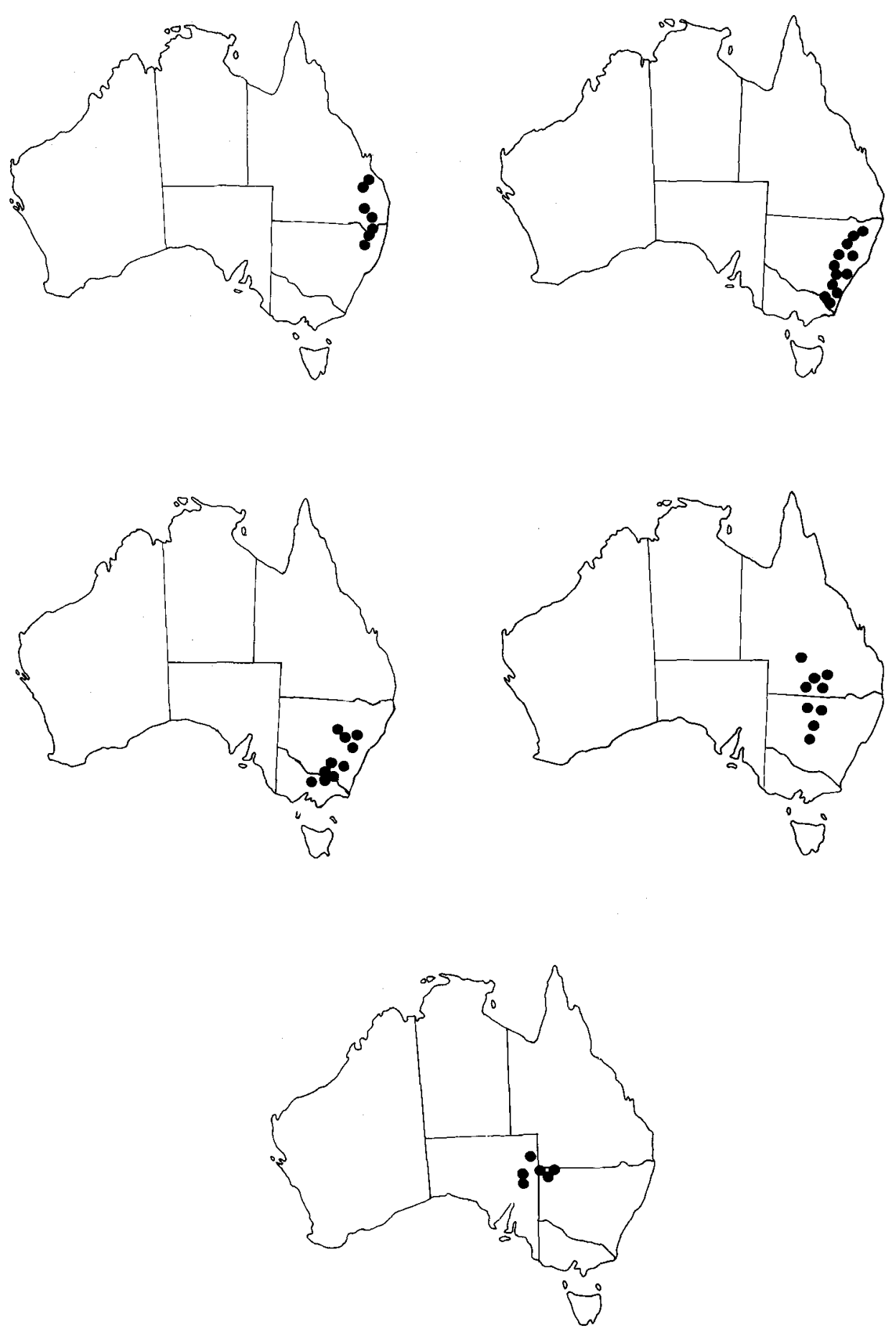

Figure 19. Distribution of Group 8, species 46-50. 46, S. parviflora; 47, S. monticola; 48, S. recta; 49, S. similis; 50, S. extrajacens. 

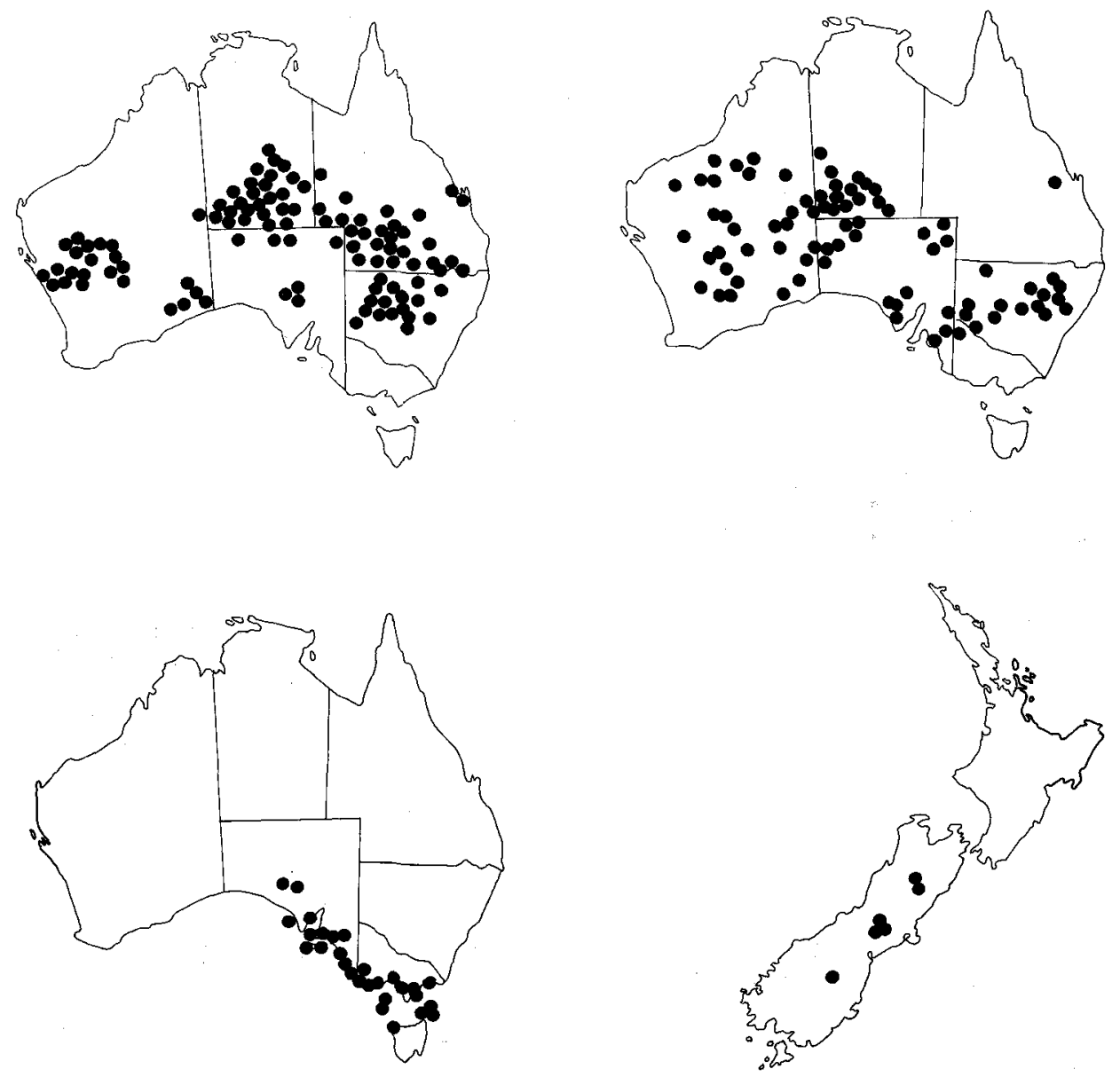

Figure 20. Distribution of Group 9, species 51-54. 51, S. affinis; 52, S. microphylla; 53, S. lessertiifolia; 54, S. novae-zelandiae. 

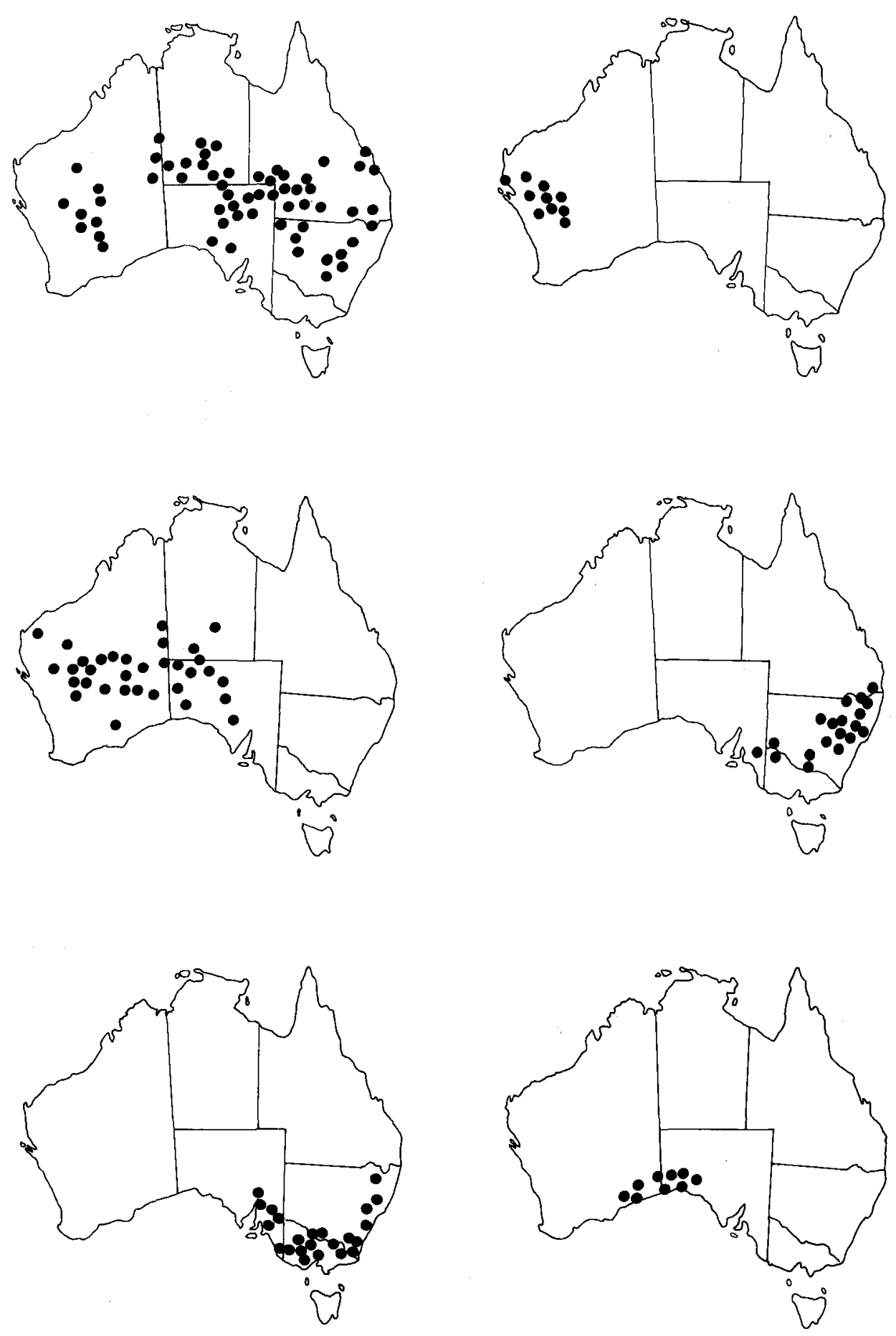

Figure 21. Distribution of Group 10, species 55-60. 55, S. oroboides; 56, S. paucifoliolata; 57, S. tenuis; 58, S. reticulata; 59, S. behriana; 60, S. campestris. 

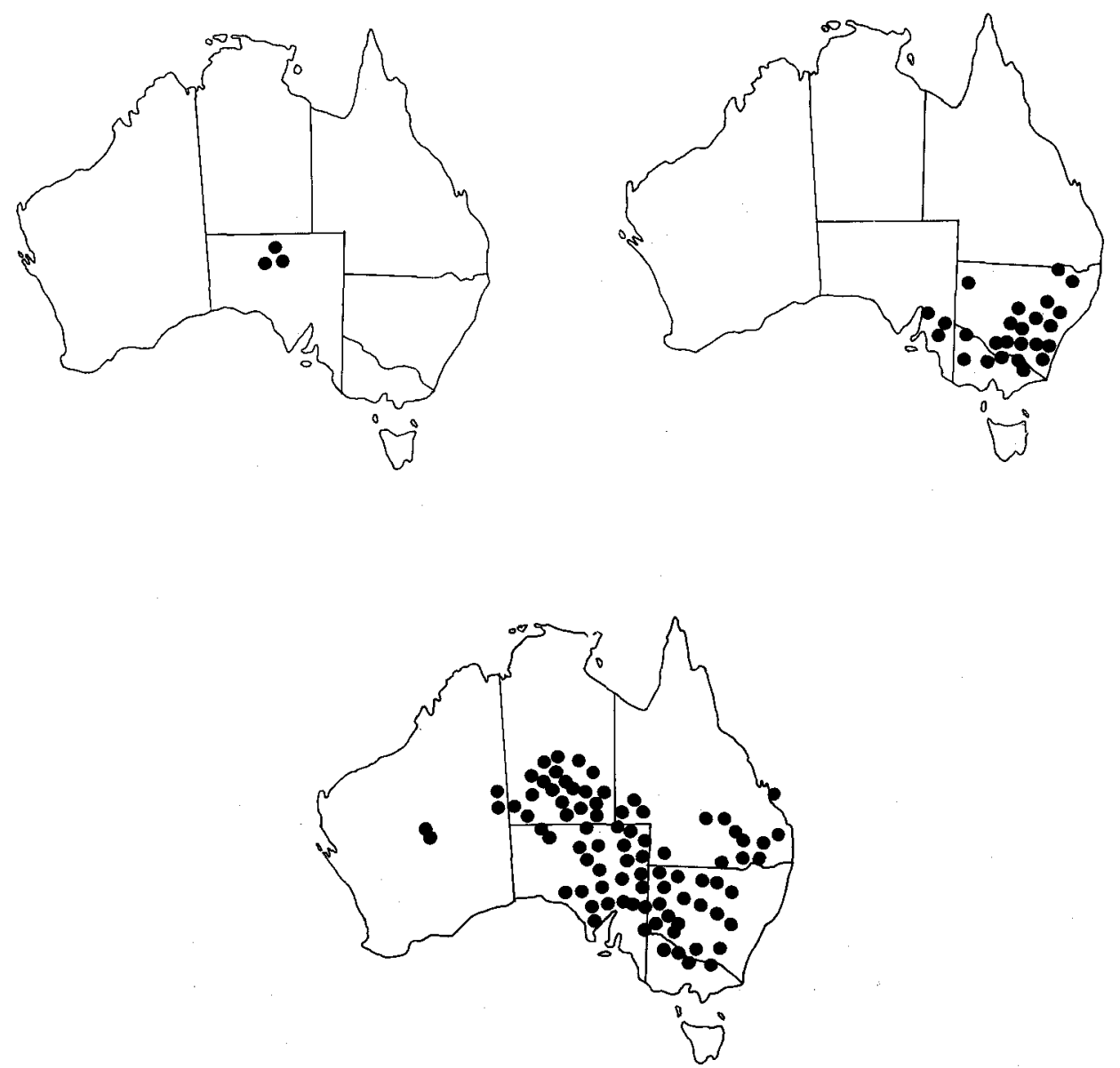

Figure 22. Distribution of Group 10, species 61-63. 61, S. vestita; 62, S. sericea; 63, S. phacoides. 

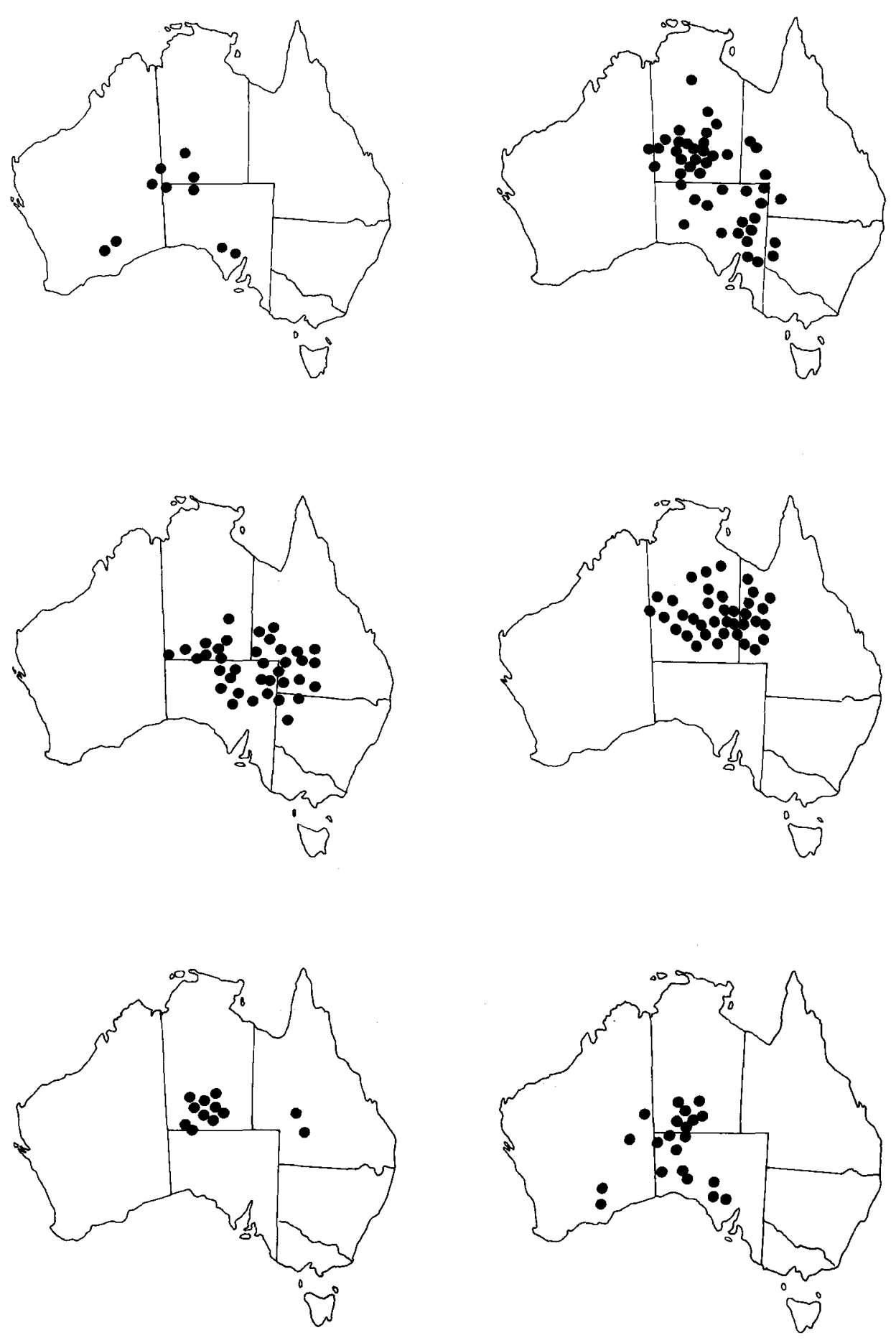

Figure 23. Distribution of Group 11, species 64-69. 64, S. disjuncta; 65, S. flavicarinata; 66, S. oligophylla; 67, S. burkei; 68, S. rostrata; 69, S. acuticarinata. 

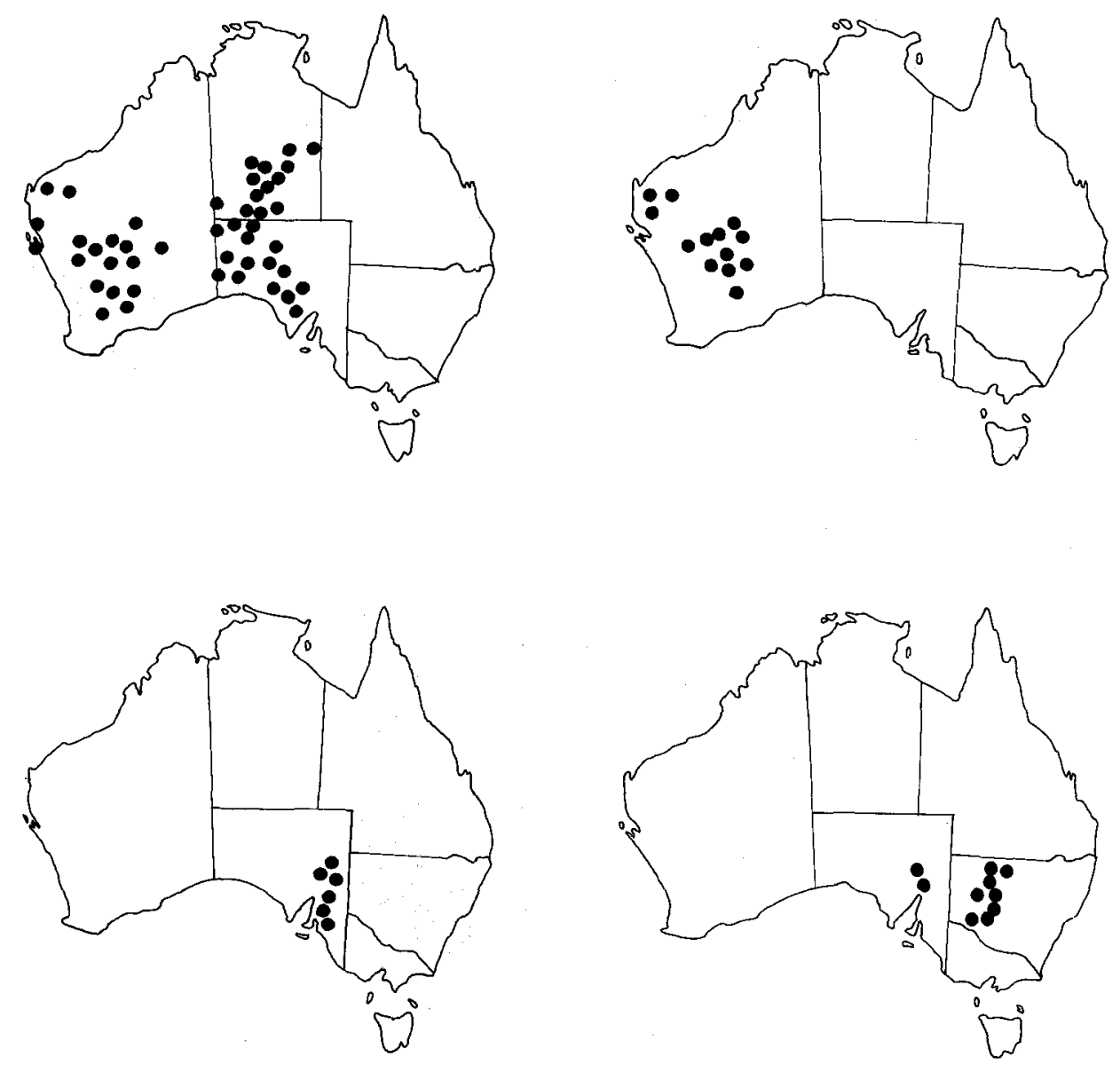

Figure 24. Distribution of Group 11, species 70-73. 70, S. canescens; 71, S. incei; 72, S. tephrotricha; 73, S. burkittii. 

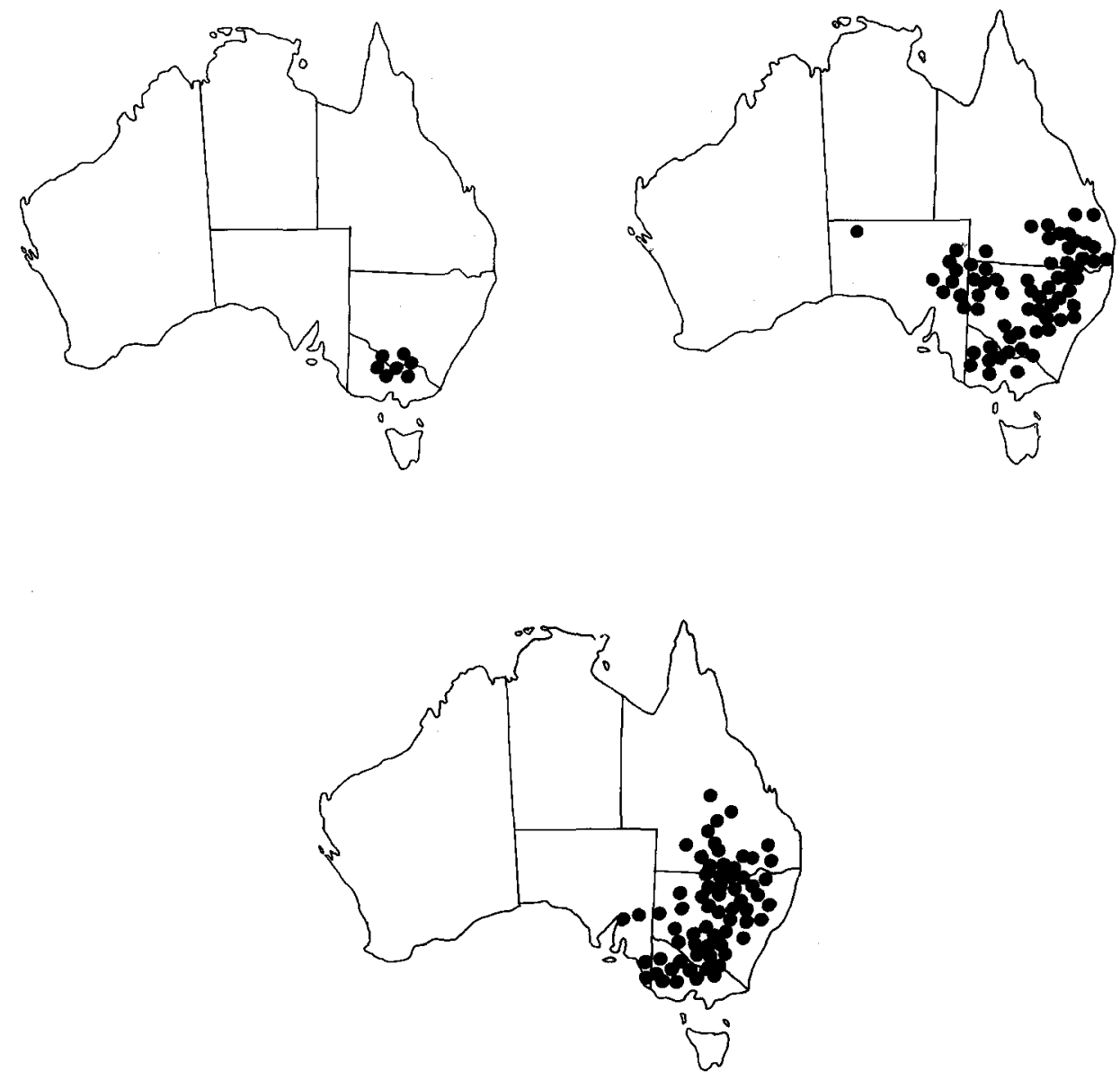

Figure 25. Distribution of Group 12, species 74-76. 74, S. plagiotropis; 75, S. swainsonioides; 76, S. procumbens. 

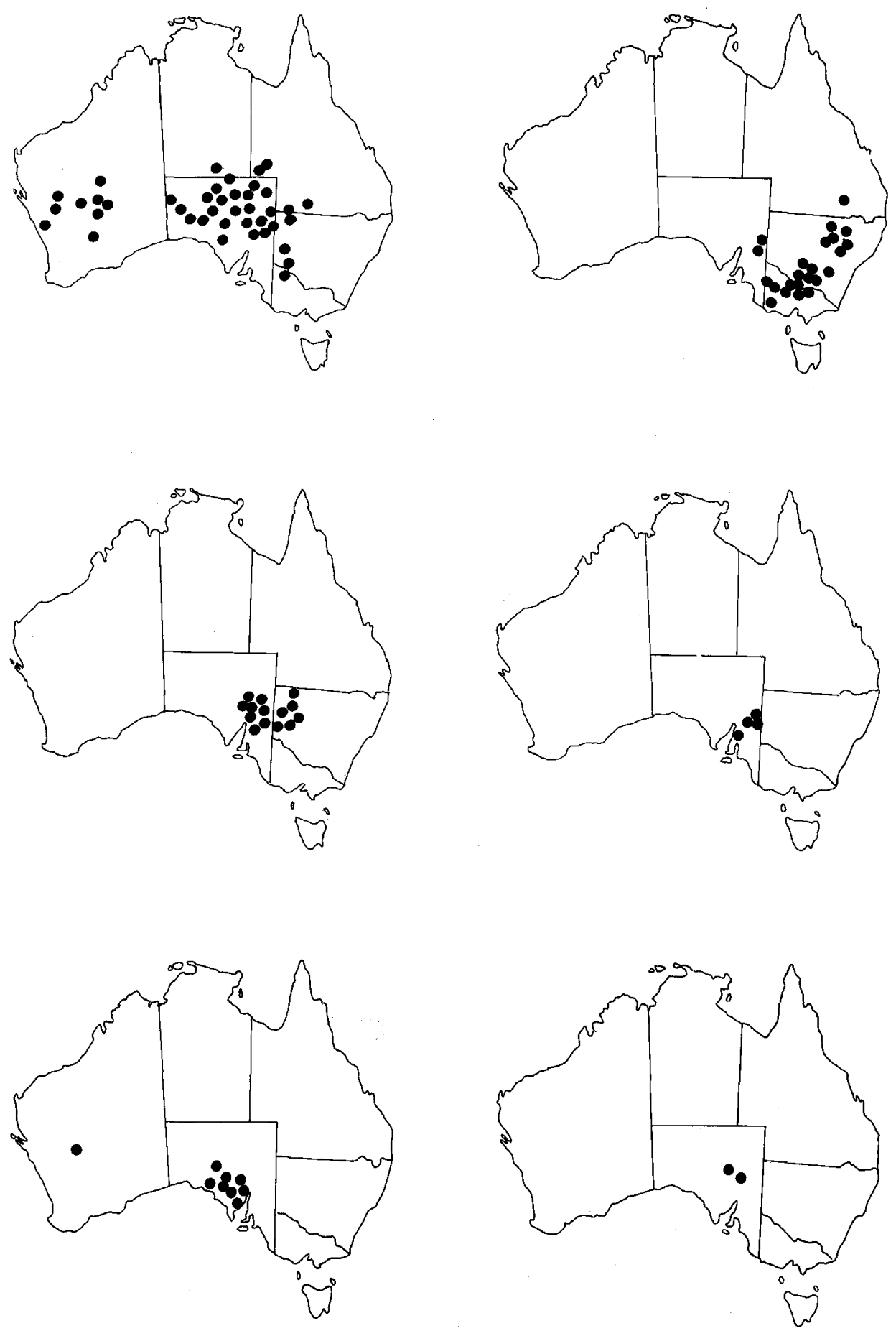

Figure 26. Distribution of Group 13, species 77-82. 77, S. purpurea; 78, S. murrayana; 79, S. fissimontana; 80, S. fuscoviridis; 81, S. microcalyx; 82, S. minutiflora. 

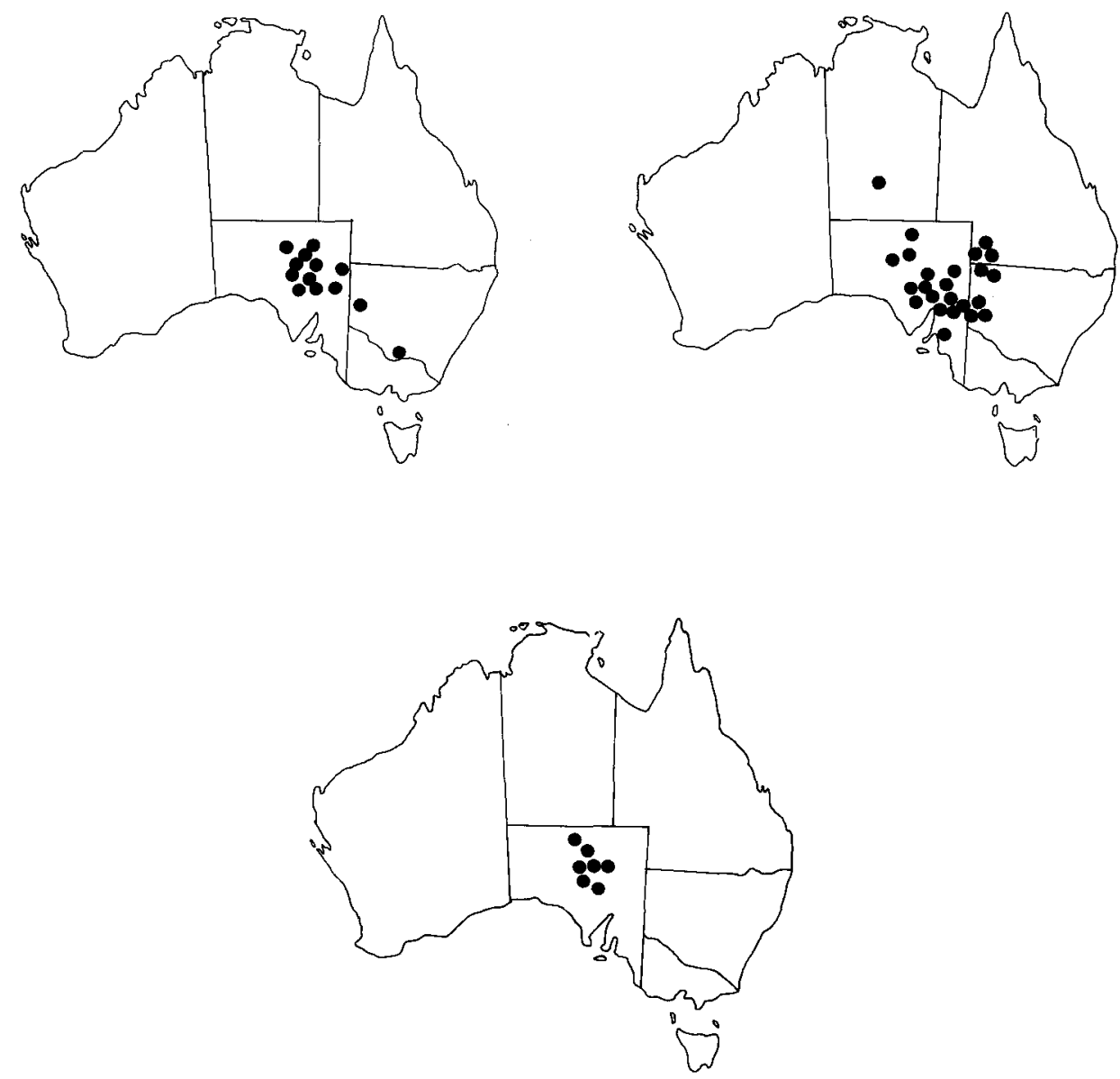

Figure 27. Distribution of Group 13, species 83-85. 83, S. adenophylla; 84, S. stipularis; 85, S. eremaea. 


\section{Index}

New names and combinations are printed in boldface, major synonyms are printed in italics.

Clianthus formosus (G. Don) Ford \& Vickery 469

Swainsona acuticarinata (A. Lee) J. Thompson 533

S. adenophylla J. Black 552

S. affinis (A. Lee) J. Thompson 508

S. beasleyana F. Muell. 470

S. beasleyana subsp. elegantoides A. Lee 462

S. behriana F. Muell. ex J. Black. 520

S. brachycarpa Benth. 459

S. bracteata (Maiden \& Betche) J. Thompson 454

S. burkei F. Muell. ex Benth. 531

S. burkei subsp. acuticarinata A. Lee 533

S. burkittii F. Muell. ex Benth. 538

S. cadellii F. Muell. ex C. Moore \& E. Betche 455

S. calcicola J. Thompson 474

S. campestris J. Black 521

S. campylantha F. Muell. 488

S. canescens (Benth.) F. Muell. 535

S. canescens var. horniana J. Black 535

S. colutoides F. Muell. 447

S. complanata J. Thompson 461

S. concinna Bailey 529

S. cornuta J. Thompson 471

S. cyclocarpa F. Muell. 484

S. decurrens A. Lee 465

S. dictyocarpa J. Black 487

S. disjuncta J. Thompson 527

S. ecallosa Sprague 466

S. elegans A. Lee 475

S. elegantoides (A. Lee) J. Thompson 462

S. eremaea J. Thompson 554

S. extrajacens J. Thompson 507

S. fissimontana J. Black 547

S. fissimontana var. coarctata J. Black 547

S. flavicarinata J. Black 528

S. formosa (G. Don) J. Thompson 469

S. forrestii F. Muell. ex A. Lee 464

S. fragilis Bailey 488 
S. fraseri Benth. 458

S. fuscoviridis J. Thompson 548

S. galegifolia (Andr.) R. Br. 450

S. gracilis Benth. 480

S. greyana Lindl. 457

S. greyana subsp. bracteata (Maiden \& Betche) A. Lee 454

S. greyana subsp. cadellii (C. Moore \& E. Betche) A. Lee 455

S. halophila J. Thompson 485

S. incei Price 536

S. kingii F. Muell. 489

S. kingii subsp. ornata A. Lee 490

S. laciniata A. Lee 497

S. laxa R. Br. 449

S. leeana J.Weber 501

S. lessertiifolia DC. 511

S. longicarinata J. Thompson 493

S. longipilosa J. Thompson 472

S. luteola F. Muell. 499

S. maccullochiana F. Muell. 467

S. microcalyx J. Black 550

S. microcalyx subsp. adenophylla (J. Black) A. Lee 552

S. microcalyx var. adenophylla (J. Black) J. Black 552

S. microphylla A. Gray 510

S. microphylla subsp. affinis A. Lee 508

S. microphylla subsp. glabrescens A. Lee 508

S. microphylla subsp. minima A. Lee 510

S. microphylla subsp. pallescens A. Lee 508

S. microphylla subsp. tomentosa A. Lee 510

S. minutiflora A. Lee 551

S. monticola Cunn. ex Benth. 503

S. morrisiana J. Black 546

S. murrayana Wawra 546

S. murrayana subsp. eciliata A. Lee 546

S. novae-zelandiae Hook. f. 513

S. novae-zelandiae var. glabra Simpson 513

S. occidentalis F. Muell. 481

S. oligophylla F. Muell. ex Benth. 529

S. oliveri F. Muell. 500

S. oroboides F. Muell. ex Benth. 514

S. oroboides subsp. hirsuta (J. Black) A. Lee 520

S. oroboides subsp. reticulata (J. Black) A. Lee 518 
S. oroboides subsp. sericea A. Lee 523

S. oroboides var. hirsuta J. Black 520

S. paradoxa W. Fitzg. 483

S. parviflora Benth. $\quad 502$

S. parviflora var. vestita C. White \& Francis 506

S. paucifoliolata J. Thompson 516

S. pedunculata A. Lee 473

S. perlonga J. Thompson 492

S. phacoides Benth. 525

S. phacoides subsp. grandiflora (Benth.) A. Lee 494

S. phacoides var. argyrophylla J. Black 525

S. phacoides var. oocarpa J. Black 525

S. plagiotropis F. Muell. 540

S. procumbens (F. Muell.) F. Muell. 542

S. procumbens var. parvifolia J. Black 542

S. pterostylis (DC.) Bakh. f. 481

S. purpurea (A. Lee) J. Thompson 544

S. pyrophila J. Thompson 448

S. queenslandica J. Thompson 453

S. recta A. Lee 505

S. reticulata J. Black 518

S. rigida (Benth.) J. Black 449

S. rostellata A. Lee 478

S. rostrata J. Thompson 532

S. rotunda J. Thompson 479

S. sejuncta J. Thompson 452

S. sericea (A. Lee) H. Eichler

S. similis J. Thompson 506

S. stenodonta F. Muell. 460

S. stipularis F. Muell. 553

S. stipularis var. longialata A. Lee 544

S. stipularis var. purpurea A. Lee 544

S. swainsonioides (Benth.) A. Lee ex J. Black 541

S. tanamiensis J. Thompson 496

S. tenuis E. Pritzel 517

S. tephrotricha F. Muell. 537

S. uniflora J. Black 525

S. unifoliolata F. Muell. 495

S. vestita J. Thompson 522

S. villosa J. Black 477

S. viridis J. Black 491 